\title{
Vitamin D and Multiple Sclerosis : immunological and clinical outcome
}

Citation for published version (APA):

Knippenberg, S. A. M. (2013). Vitamin D and Multiple Sclerosis : immunological and clinical outcome. [Doctoral Thesis, Maastricht University]. Maastricht University. https://doi.org/10.26481/dis.20130328sk

Document status and date:

Published: 01/01/2013

DOI:

10.26481/dis.20130328sk

Document Version:

Publisher's PDF, also known as Version of record

\section{Please check the document version of this publication:}

- A submitted manuscript is the version of the article upon submission and before peer-review. There can be important differences between the submitted version and the official published version of record.

People interested in the research are advised to contact the author for the final version of the publication, or visit the DOI to the publisher's website.

- The final author version and the galley proof are versions of the publication after peer review.

- The final published version features the final layout of the paper including the volume, issue and page numbers.

Link to publication

\footnotetext{
General rights rights.

- You may freely distribute the URL identifying the publication in the public portal. please follow below link for the End User Agreement:

www.umlib.nl/taverne-license

Take down policy

If you believe that this document breaches copyright please contact us at:

repository@maastrichtuniversity.nl

providing details and we will investigate your claim.
}

Copyright and moral rights for the publications made accessible in the public portal are retained by the authors and/or other copyright owners and it is a condition of accessing publications that users recognise and abide by the legal requirements associated with these

- Users may download and print one copy of any publication from the public portal for the purpose of private study or research.

- You may not further distribute the material or use it for any profit-making activity or commercial gain

If the publication is distributed under the terms of Article $25 \mathrm{fa}$ of the Dutch Copyright Act, indicated by the "Taverne" license above, 
Vitamin D and Multiple Sclerosis:

immunological and clinical outcome 
Copyright SAM Knippenberg, Maastricht 2013

ISBN 9789461592125

Financial support for the publication of this thesis was kindly provided by : Biogen Idec International B.V., Genzyme Europe B.V., Merck Serono the Netherlands B.V., Nationaal MS Fonds, Science Plus Group, Stichting MS research and TEVA Netherlands B.V. 


\title{
Vitamin D and Multiple Sclerosis: immunological and clinical outcome
}

\author{
PROEFSCHRIFT \\ ter verkrijging van de graad van doctor aan de Universiteit Maastricht, \\ op gezag van de Rector Magnificus, Prof. Dr. L.L.G. Soete \\ volgens het besluit van het College van Decanen, \\ in het openbaar te verdedigen \\ op donderdag 28 maart 2013 om 16.00 uur \\ door
}

Stephanie Alexandra Marieke Knippenberg geboren op 29 januari 1983 te Bergen op Zoom 


\section{Promotores}

Prof. dr. R.M.M. Hupperts

Prof. dr. J.W. Cohen Tervaert

\section{Copromotor}

Dr. J.G.M.C. Damoiseaux

Dr. Y. Bol

\section{Beoordelingscommissie}

Prof. dr. M.H. de Baets (voorzitter)

Prof. dr. J. de Keyser, Universitair Ziekenhuis Brussel

Prof. dr. R. Van Oostenbrugge

Prof. dr. V. Somers, Universiteit Hasselt

Prof. dr. F. Verhey 


\section{Contents}

Abbreviations $\quad 6$

Chapter 1 General introduction and aims 9

Chapter 2 Effects of vitamin D on the peripheral adaptive immune system: a 25 review

Chapter 3 Effects of vitamin D3 supplementation on peripheral B cell differentiation and isotype switching in patients with multiple sclerosis

Chapter 4 Reduction in IL-10 producing B cells (Breg) in multiple sclerosis is accompanied by a reduced naïve/memory Breg ratio during a relapse but not in remission

Chapter 5 Role of vitamin D in multiple sclerosis: implications for disease management

Chapter 6 Vitamin D status in MS correlates negatively with retinal nerve fibre layer thickness

Chapter 7 Poor vitamin D status is correlated with depression, but not fatigue in multiple sclerosis

Chapter 8 Higher levels of reported sun exposure, and not vitamin D status, are associated with less depressive symptoms and fatigue in MS

Chapter 9 General discussion

Chapter 10 Summary

Chapter 11 Nederlandse samenvatting (Summary in Dutch)

Dankwoord (Acknowledgements)

Publications 


\section{Abbreviations}

\begin{tabular}{|c|c|}
\hline $1,25(\mathrm{OH})_{2} \mathrm{D}$ & 1,25-dihydroxyvitamin D \\
\hline $25(\mathrm{OH}) \mathrm{D}$ & 25-hydroxyvitamin D \\
\hline 7AAD & 7-aminoactinomycin D \\
\hline APC & antigen presenting cell \\
\hline BBB & Blood brain barrier \\
\hline BFA & Brefeldin-A \\
\hline BMD & Bone mineral density \\
\hline Breg & Regulatory B cell \\
\hline$C D$ & Cluster defining molecule \\
\hline $\mathrm{CpG}$ & C-phosphate-G \\
\hline CNS & Central nervous system \\
\hline CSF & Cerebrospinal fluid \\
\hline CYP & Cytochrome P \\
\hline DBP & Vitamin D binding protein \\
\hline $\mathrm{DC}$ & Dendritic cell \\
\hline DNA & Desoxyribnucleic acid \\
\hline $\mathrm{EAE}$ & Experimental autoimmune encephalitis \\
\hline EDSS & Expanded disability status scale \\
\hline FITC & Fluorescein isothiocyanate \\
\hline FSS & Fatigue severity scale \\
\hline FoxP3 & Forkhead box P3 \\
\hline GA & Glatiramer acetate \\
\hline GM-CSF & Granulocyte macrophage-colony stimulating factor \\
\hline HADS & Hospital Anxiety and Depression scale \\
\hline HPA & hypothalamus-pituitary-adrenal \\
\hline IFN- $\beta$ & Interferon beta \\
\hline IFN- $\gamma$ & Interferon gamma \\
\hline $\lg$ & Immunoglobulin \\
\hline IL- & Interleukin \\
\hline MBP & Myelin basic protein \\
\hline $\mathrm{MHC}$ & Major histocompatibility complex \\
\hline MMP & Matrix metalloproteases \\
\hline MRI & Magnetic resonance imaging \\
\hline mRNA & Messenger ribonucleic acid \\
\hline MS & Multiple sclerosis \\
\hline OCT & Optical coherence tomography \\
\hline ON & Optic neuritis \\
\hline PBMC & Peripheral blood mononuclear cells \\
\hline PE & R-Phycoerythrin \\
\hline
\end{tabular}




$\begin{array}{ll}\text { PEcy7 } & \text { Conjugate of PE and cyanine dye } 7 \\ \text { PerCP } & \text { Peridinin chlorophyll protein } \\ \text { PET } & \text { Positron emission tomography } \\ \text { PHA } & \text { Phytohaemagglutinin } \\ \text { PMA } & \text { Phorbol 12-myristate 13 acetate } \\ \text { PPMS } & \text { Primary progressive multiple sclerosis } \\ \text { Rag } & \text { Recombination activating genes } \\ \text { RGC } & \text { Retinal ganglion cell } \\ \text { RCT } & \text { Randomized controlled trials } \\ \text { RNA } & \text { Ribonucleic acid } \\ \text { RNFL } & \text { Retinal nerve fibre layer } \\ \text { RRMS } & \text { Relapsing remitting multiple sclerosis } \\ \text { SCN } & \text { Suprachiasmatic nucleus } \\ \text { SPMS } & \text { Secondary progressive multiple sclerosis } \\ \text { TGF- } \beta & \text { Tumour growth factor beta } \\ \text { Th1 } & \text { Thelper cell type 1 } \\ \text { Th17 } & \text { Thelper cell type 17 } \\ \text { Th2 } & \text { Thelper cell type 2 } \\ \text { TLR } & \text { Toll like receptor } \\ \text { TNF- } \alpha & \text { Tumour necrosis factor alpha } \\ \text { Tr1 } & \text { T regulatory cell type 1 } \\ \text { Treg } & \text { Regulatory T cell } \\ \text { UVB } & \text { Vitra violet B radiation } \\ \text { VDBP } & \text { Vitamin D binding protein } \\ \text { VDR } & \text { Vitamin D receptor } \\ \text { VEP } & \\ \text { VLA-4 } & \end{array}$





\section{Chapter 1}

\section{General introduction and aims}

Adapted from S. Knippenberg, R. Hupperts, J. Damoiseaux. Multiple sclerosis. Book chapter EASI Booklet for Family Doctors. 


\section{CHAPTER 1}

\section{Multiple sclerosis}

Multiple sclerosis (MS) is a chronic, invalidating disease of the central nervous system (CNS), characterized by focal inflammation, demyelination, and loss of neurons. The inflammation causes areas of scars within the CNS, giving the disease its name: multiple areas of hard scars (sclerosis). The exact cause of MS remains unknown, but it has been proposed to arise from an interplay of genetic and environmental factors (1). The age at disease onset is typically between 20 and 50 years of age, although MS can occasionally have its onset during childhood or in the elderly (1). Women are affected twice as frequently as men and this ratio may be increasing (2). The prevalence in the Netherlands is about 0.51 per 1000 males and 1.24 per 1000 women (3).

MS has an unpredictable clinical course that can follow different patterns. Most patients (80\%) start with a relapsing remitting form of MS (RRMS) that generally becomes progressive overtime, while patients become more severely disabled. In this progressive phase, the disease is referred to as secondary progressive (SP) MS. A small proportion of patients (20\%) experiences progressive disability from disease onset onwards without relapses and remissions, and in these patients the disease is called primary progressive (PP) MS (1). To rate the neurological disability in MS patients, the Kurtze expanded disability status scale (EDSS) is frequently used. The EDSS score is based on neurological testing and examination of 7 areas of the CNS; pyramidal (motor), cerebellar (coordination), brainstem (speech and swallowing), sensory (touch and pain), bowel and bladder functions, visual, and mental functions (mood and fatigue). The EDSS score is an ordinal scale in half-point increments ranging from 0 (normal neurologic examination) to 10 (death due to MS) (4).

The availability of immune modulating treatments in MS improved the perspective for MS patients; however, MS remains a chronic and incurable disease. Prognosis depends on the subtype of the disease, gender, and initial symptoms. Relapsing remitting onset of the disease, optic neuritis as initial symptom, and female gender are associated with a better prognosis (5).

\section{Clinical symptoms of MS}

MS patients can suffer from a wide variety of neurological symptoms, which are diverse in quantity and quality, and can arise from dysfunction of each component of the CNS. Although loss of motor function is the most well recognized symptom, symptoms can also include sensory impairment, balance disorders, bowel and bladder dysfunction and sexual dysfunction. Besides the physical symptoms of MS, fatigue and neuropsychiatric symptoms are frequent and important predictors of the quality of life of MS patients (6). In addition, visual impairment has been described as an important predictor of quality of life in MS (7). In this thesis we will focus on these clinical symptoms, 
including visual impairment, fatigue and neuropsychiatric symptoms, e.g. cognitive impairment, anxiety and depression.

\section{Visual impairment}

Visual impairment appears frequent and is often irreversible. Eighty per cent of patients with MS will develop visual dysfunction during the course of their disease and it is the presenting feature in $50 \%$ (8-10). In addition, visual impairment is strongly related to overall health related quality of life in $M S(7,11)$. Symptoms of impaired vision may result from a variety of pathological processes, including inflammatory, demyelinating and axonal degenerative process involving the retina, optic nerves, chiasm, and tracts (the afferent visual pathway)(12). Common functional defects of the afferent visual pathway in MS are for example impaired visual acuity, visual field loss and impaired colour visual acuity. The eye disorder most associated with MS is optic neuritis (ON), which refers to inflammation of the optic nerve. In $20 \%$ of patients with MS, ON is presenting symptom and $50 \%$ of patients with isolated ON develop MS within 15 years (13). Patients with ON report acute to subacute vision loss, colour desaturation, and pain with eye movements (14). Some recovery may occur within 1 month of symptom onset, with normal vision reported by $60 \%$ of MS patients after 15 years (14).

\section{Fatigue}

Fatigue is one of the most common and disabling symptoms; up to $92 \%$ of MS patients complain of fatigue (15). Despite its high prevalence, the pathogenesis of fatigue in MS is poorly understood. The most commonly proposed primary mechanisms of fatigue in MS include influences of pro-inflammatory cytokines and endocrine influences. Increased levels of tumour necrosis factor (TNF)- $\alpha$ and interferon (IFN) $-\gamma$ are found in fatigued MS patients, compared to non-fatigued MS patients (16). Dysfunction of the hypothalamus-pituitary-adrenal (HPA)-axis, characterized by lower than normal cortisol secretion, is often seen in fatigued patients. However, in MS the relationship between fatigue and HPA-axis shows conflicting results $(16,17)$. In addition, damage to CNS, e.g. axonal damage and demyelisation, is thought to be involved in the pathogenesis of fatigue. Using positron emission tomography (PET), a reduced glucose metabolism in the frontal lobe and basal ganglia was seen in MS patients with fatigue (18). Moreover, proton magnetic resonance spectroscopy imaging revealed widespread axonal damage in MS patients with fatigue (19). Although biological mechanisms are widely explored in fatigue, psychological factors are also reported to influence fatigue levels. For instance, personality traits, such as emotional instability are contributing to 


\section{CHAPTER 1}

fatigue in MS patients (20). In addition, fatigue in MS can be secondary to several other factors e.g. sleep disorders, change in physical activity and depression $(20,21)$.

\section{Neuropsychiatric symptoms}

Beside the physical symptoms and fatigue, emotional problems are frequent in MS, and psychiatric comorbidity is high; patients show increased levels of depression and anxiety (22). The prevalence of depression is estimated at 27 to $50 \%$ of the MS population, and the life-time prevalence of depression in MS patients is estimated at $50 \%$ (23). Emotional disorders and depression in particular, are more common in MS patients than in patients with other chronic diseases with the same level of physical impairment (24). There is no clear association between the presence of depression and disease related variables, such as neurological disability, disease course or disease duration $(25,26)$. Similar to fatigue, depressive symptoms are hypothesized to arise from immune dysfunction and / or damage to the CNS. Several studies showed a higher brain MRI lesion load in frontal regions and a reduction in temporal and hippocampal volume (27-30). In addition, higher levels of circulating pro-inflammatory cytokines are found in depressed MS patients compared to non-depressed MS patients $(31,32)$.

Cognitive impairment is also frequent in MS (33). Speed of information processing and memory are most frequently damaged; approximately $50 \%$ of MS patients seem to have damage in these domains (33). Mental slowness is particularly problematic in MS patients since it has a negative influence on other cognitive abilities $(33,34)$. Cognitive impairment is only loosely related to disease variables, such as disease duration (35) and physical disability (36). Magnetic resonance imaging (MRI) variables on the other hand, are more closely related to cognitive impairment. In particular cortical lesions and atrophy have been demonstrated to be independent predictors of cognitive impairment (37), suggesting an important role for cortical grey matter injury in the pathogenesis of cognitive impairment in MS. Although it has been shown that cortical lesions could occur secondary to white matter damage in relation to Wallerian degeneration (38), in particular in recent diagnosed MS, inflammation is thought to play an important role in cortical tissue damage (39).

\section{Diagnosis of MS}

Because of its heterogeneous first presentation (Table 1), MS can be hard to diagnose. The diagnosis is made clinically, based upon the appearance of MS lesions in different parts of the CNS that have occurred at different points in time. To facilitate and standardize the diagnostic process, diagnostic criteria were defined. The McDonald criteria are most recommended (40). The McDonald criteria focus on the demonstration of the 
dissemination of MS lesions in time and space by predominantly clinical and radiologic data (Table 2). Clinically, two distinct episodes of neurological impairment, for which different inflammatory or demyelinated lesions within the CNS are presumed, can be sufficient for the diagnosis of MS, provided that the neurological impairment has been objectively observed for at least 24 hours (40). Since many people seek medical attention after one episode, additional testing is often necessary. The most commonly used additional diagnostics are MRI and analysis of the cerebrospinal fluid (CSF). MRI of the brain and spine may show areas of inflammation or demyelination (Figure 1). Gadolinium can be administered intravenously as a contrast to highlight active inflammatory lesions and demonstrate the existence of older lesions not associated with symptoms at the moment of the evaluation. The sensitivity of MRI criteria for MS is between $35 \%$ and $100 \%$, and specificity is between $36 \%$ and $92 \%$ (41). CSF obtained by lumbar puncture can provide information about inflammation of the CNS by testing it for oligoclonal bands of immunoglobulin $\mathrm{G}$ (IgG) (Figure 2). Oligoclonal bands are a result of an antigenic driven response and found in $75-85 \%$ of subjects with MS. Combination of MRI and CSF criteria for MS enhance sensitivity (56-100\%) and specificity (53-96\%) $(40,41)$. Furthermore, the nervous system of a person with MS responds less actively to stimulation of the optic nerve and sensory nerves due to demyelination. These diminished responses can be examined using visual and sensory evoked potentials (42).

Table 1. Common first symptoms of MS

\begin{tabular}{ll}
\hline Presenting symptom & Percentage of patients \\
\hline Motor weakness of the limbs & $43-46 \%$ \\
Sensory problems & $41-49 \%$ \\
Optic neuritis & $22.5-36 \%$ \\
Double vision & $13-19 \%$ \\
Ataxia & $8 \%$ \\
Bladder dysfunction & $1.25 \%$ \\
Cranial nerve dysfunctions & $1.25 \%$ \\
\hline
\end{tabular}




\section{CHAPTER 1}

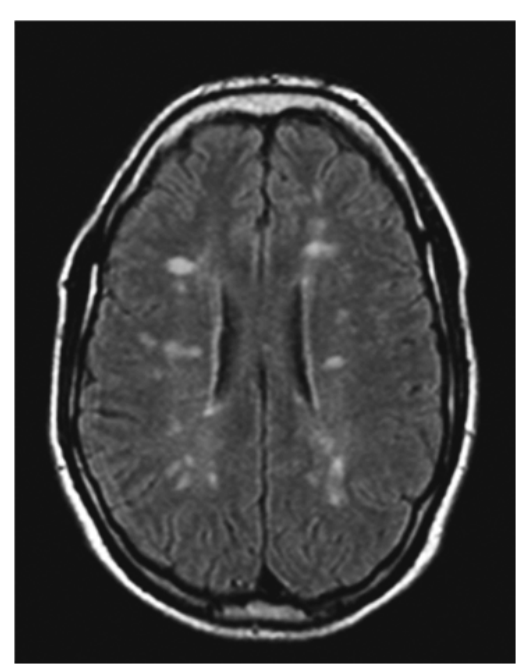

Figure 1. Brain MRI of a MS patient. MRI showing multiple periventricular white matter lesions, consistent with multiple sclerosis.

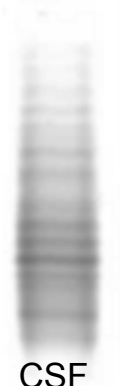

CSF

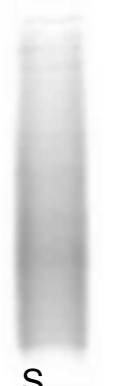

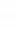

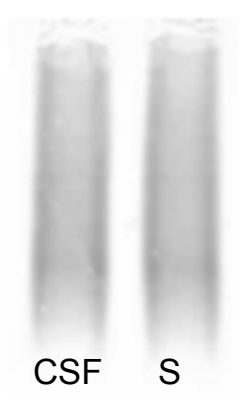

$S$
Figure 2. Patterns from isoelectric focusing of paired serum (S) and concentrated cerebrospinal fluid (CSF) adjusted to the same amount of IgG applied. A patient with multiple sclerosis (left) and a healthy control (right) are displayed.

\section{Optical coherence tomography in MS}

An additional way to measure the visual system is by optical coherence tomography (OCT). OCT is emerging as a new noninvasive diagnostic tool in assessing the impact of MS on the retina by measuring the retinal nerve fiber layer (RNFL) thickness. The OCT instrument works by measuring the echo time delay and intensity of backreflection of light from different structures in the eye, including the RNFL. Measuring the RNFL thickness is of additional interest since this layer is devoid of myelin. Quantification of the RNFL may therefore provide the opportunity to monitor axonal damage (43). This is of interest, since there is only a poor correlation between quantification of axonal and neuronal loss by brain MRI and functional clinical disabilities as measured by clinical scales (44). RNFL thickness measured by OCT, was shown to correlate with visual loss in MS patients with or without a history of ON (45), to distinguish MS disease course (46), and to correlate with EDSS score and disease duration (47). However, more research is needed to evaluate whether RNFL thinning as measured by OCT is reliable in the long term for measuring axonal injury (48). Until then, OCT enables investigators to rapidly and reproducibly evaluate the structural composition of the retina. Ultimately, measuring the visual pathway by OCT could be used to noninvasively 
capture reductions in axonal loss that may be associated with neuroprotective properties of therapies.

\section{Pathogenesis of MS}

The T cell model

In the past decades MS was considered a classical T cell mediated autoimmune disease. This was based on early pathological findings in MS showing primarily T cell infiltrates that surrounded the demyelinating lesions in the CNS (49). In addition, the animal model of MS, experimental autoimmune encephalomyelitis (EAE), is triggered by a $T$ cell mediated response to myelin antigens (50), which was shown in adoptive transfer experiments $(51,52)$. The classical T cell models have been reviewed extensively $(53,54)$. In human, the T cell model includes activation of naïve T cells in the peripheral lymphoid organs, where an (unknown) antigen is presented by antigen presenting cells (APC). The activated T cells predominantly adopt a T helper (Th) 1 cell or Th17 cell profile, characterized by the production of the pro-inflammatory cytokines IFN- $\gamma$ and interleukin (IL)-17, respectively. Normally, regulatory T cells (Tregs) are capable of controlling this pro-inflammatory immune response. In MS, however, it was shown that Tregs are less effective in this suppression $(55,56)$. After their activation in the periphery, $T$ cells up-regulate surface molecules like selectins and integrins, such as very late antigen 4 (VLA-4), that enable them to adhere more efficiently to the endothelial cells of the blood brain barrier (BBB). To cross the BBB, $T$ cells express matrix metalloproteases (MMP's), which play a role in both degrading the extracellular matrix surrounding the BBB as well as myelin components. Within the CNS, T cells are reactivated by CNS microglial cells or by invading monocytes and macrophages. The activated T cells then mediate injury directly by the production of cytokines or indirectly by activation of macrophages resulting in degradation of the myelin sheath and axons, leading to neuronal dysfunction and eventually loss of neurons.

\section{B cells within the T cell model}

The notion that not only T cells, but also B cells and plasma cells can be found in CNS lesions (57), challenged the dogma of an exclusive T cell pathology in MS. Next to the presence of oligoclonal bands in CSF, the demonstration that peripheral B cell depletion by Rituximab leads to a reduction in disease activity in MS further highlighted a role for B cells in MS (58). It is now generally believed that B cells play an important role in the $T$ cell responses responsible for the pathogenesis of MS by antigen presentation and cytokine production (59). Especially memory B cells, characterized by the expression of $C D 27$, are potent APC and producers of the pro-inflammatory cytokines, IL- 6 and TNF- $\alpha$. Depletion of memory B cells in MS resulted in a decreased proportion of TNF- $\alpha$ and IFN- $\gamma$ producing T cells, suggesting that memory B cells are indeed im- 


\section{CHAPTER 1}

portant drivers of the pro-inflammatory $T$ cell response (60). Furthermore, in particular memory $B$ cells have a high expression of VLA-4, enabling them to cross the BBB. Indeed, the memory $B$ cell subset is enriched in CSF during active disease $(61,62)$. A role for B cells within the CNS has been highlighted by the presence of the follicular like structures acting like germinal centers in the meninges, which has been linked with severe cortical pathology and an aggressive clinical course, further reinforcing the concept of their role in disease progression (63). In EAE, B cell-deficient ( $\mu \mathrm{MT})$ mice, unlike wild-type mice, were unable to recover from EAE, which gave rise to the idea that $B$ cells could also restrain the severity of autoimmune diseases (64). Indeed, in EAE $B$ cells appeared to have opposing functions. Depletion of B cells with anti-CD20 showed a differential outcome depending on the administration schedule; prophylactic administration of anti-CD20 before EAE induction increased disease severity while administration of anti-CD20 during the disease suppressed disease severity (65). This highlights the existence of a regulatory $B$ cell population, which may influence early stages of the disease. Regulatory B cells are able to produce IL-10 and in MS patients it was shown that this population produces less IL-10 compared to healthy controls (66). Exploiting these pro-inflammatory and anti-inflammatory properties of $B$ cells could be an important target of MS treatment.

\section{Treatment}

Since there is no cure for MS, current treatments attempt to prevent relapses and disability progression. Acute relapses are treated with high-dose intravenous corticosteroids, such as methylprednisolone. First-line maintenance therapies are betainterferons and glatiramer acetate. The first-line therapies are immune-modulating drugs; they skew the balance between a pro-inflammatory and anti-inflammatory immune response towards an anti-inflammatory immune response (67). Nonresponders to first-line drugs need more aggressive therapy to prevent increasing disability. Second-line therapies include Mitoxantrone, Natalizumab and Fingolimod. Mitoxantrone is an immuno-suppressive drug developed to treat malignancies. It is used for the treatment of very active RRMS or SPMS and gives a significant reduction in relapses, an overall clinical improvement, and a reduction in active lesions on MRI (68). Natalizumab is a more recent drug in the group of disease modifying drugs available for the treatment of MS. It is a monoclonal antibody directed to VLA-4, an integrin expressed by white blood cells, including B- and T cells. Its primary function is to inhibit migration of leukocytes towards the site of inflammation, i.e., the CNS $(69,70)$. The latest treatment approved for MS is the oral drug Fingolimod. Fingolimod was shown to reduce relapses and to delay disease progression in RRMS patients $(71,72)$. Fingolimod exerts its effect by preventing lymphocytes to migrate from the secondary 
lymphoid tissues, resulting in a marked decrease of circulating T- and B cells (73). Currently, numerous new drugs are being tested for their efficacy in MS treatment (74).

Besides pharmacological treatment, multidisciplinary symptom management can also improve the quality of life of MS patients. This can include medication to reduce spasms, bladder problems or non-pharmacological therapy, such as physiotherapy to improve mobility (75).

\section{Vitamin D in MS}

A poor vitamin D status is an important environmental risk factor for the development of MS (76). Indeed, an increasing body of epidemiological research supports a role for vitamin $D$ in the pathogenesis of MS $(77,78)$. In addition, two prospective studies showed an inverse association between relapse rate and vitamin $D$ status in MS patients $(79,80)$, suggesting a causal effect for vitamin $D$ in relapses. Vitamin D mediates a range of effects on the body, however, the immunomodulatory effects of vitamin $D$ may be one of the key mechanisms underlying the association between vitamin $D$ and MS. Vitamin D is known to affect the adaptive immune system, in particular APC and T cells. The recent attention for B cells in the pathogenesis of MS has not yet resulted in many studies exploring the relationship between vitamin $D$ and $B$ cell functions. Because of the association between vitamin $D$ and clinical disease parameters in MS, attention has been focused on vitamin D as a potential (add-on) therapy in MS. For this reason, randomized controlled trials (RCT) are currently exploring clinical efficacy (81, 82). These trials mainly focus on outcome measures as relapse rate and disease progression. Interestingly, a poor vitamin $D$ status has been associated with impaired vision (83), higher levels of fatigue $(84,85)$, cognitive impairment (86-88) and more depressive symptoms (89-91) in healthy and multiple diseased populations. However, despite their high prevalence and importance in quality of life in MS, the relationships between vitamin $D$ status and fatigue, neuropsychiatric symptoms and visual impairment, are relatively unexplored in MS.

\section{Aim of this thesis}

The general aim of this thesis is to further investigate the role of vitamin D in MS patients. First, we will explore effects of vitamin D on the adaptive immune system. Instead of exploring its effect on T cells and APC, we focus on B cells. Second, we will explore the association between vitamin $D$ status and common clinical symptoms in MS patients, such as visual impairment, fatigue and neuropsychiatric symptoms, including depression, anxiety and cognitive impairment. 


\section{CHAPTER 1}

\section{Outline of this thesis}

Chapter 2 provides an overview of the literature of immunological effects of vitamin D. In chapter $\mathbf{3}$ we start with exploring the effect of vitamin D on B cells. It has been shown that $B$ cell depletion is an effective treatment in MS (58). Therefore, we hypothesized that modulating the $B$ cell response might be beneficial in MS patients. To explore whether vitamin $D$ is able to modulate $B$ cells, we examine the effect of vitamin $D$ supplementation on the $B$ cell differentiation profile in MS patients. In addition, circulating levels of immunoglobulin and B cell activating factor (BAFF) are explored before and after 12 weeks of vitamin $D$ supplementation. In chapter 4 we examine $B$ cell differentiation in RRMS patients during remission and during a relapse, in age- and sex-matched healthy controls and its relation to vitamin $D$ status. Special attention is given to a B cell subset that is able to produce IL-10, which is considered to represent regulatory B cells.

In the second part of this thesis, we switch towards clinical outcome measures. Chapter 5 provides an overview of the literature of clinical associations with vitamin D in MS. Hereafter, we expand these known clinical associations, by exploring the associations between vitamin $D$ status and clinical complaints with a profound effect on quality of life, e.g. visual impairment, fatigue and neuropsychiatric symptoms. In chapter 6 we explore the correlations between vitamin D status and visual outcome measures, such as visual acuity, visual evoked potentials (VEP), and the RNFL thickness as measured by OCT in MS patients. Chapter $\mathbf{7}$ shows the results of a retrospective study, exploring the association between vitamin $D$ status, fatigue and depressive symptoms in MS patients. In chapter $\mathbf{8}$ we extend this retrospective study, by examining the associations between vitamin $D$ status and fatigue, depression, anxiety and cognitive impairment in a large longitudinal prospective study.

This thesis concludes with a discussion in chapter 9 in which the most important findings will be reflected and in which future perspectives are provided. 
GENERAL INTRODUCTION AND AIMS

Table 2. Diagnostic criteria according to McDonald criteria 2010

\begin{tabular}{|c|c|c|}
\hline Clinical attacks & $\begin{array}{l}\text { Objective clinical evidence } \\
\text { (MRI lesions) }\end{array}$ & Additional data needed to confirm MS diagnosis \\
\hline Two or more & $\begin{array}{l}\text { Two or more } \\
\text { or } \\
\text { Objective clinical evidence of } 1 \\
\text { lesion with historical evidence of } \\
\text { another prior attack }\end{array}$ & None \\
\hline Two or more & One & $\begin{array}{l}\text { Dissemination in space } \\
\text { verified by } \mathrm{MRI}^{\mathrm{a}} \\
\text { or } \\
\text { verified by second clinical neurological attack } \\
\text { implicating a different CNS site }\end{array}$ \\
\hline One & Two or more & $\begin{array}{l}\text { Dissemination in time } \\
\text { verified by } \mathrm{MRI}^{\mathrm{a}} \\
\text { or } \\
\text { verified by second clinical neurological attack }\end{array}$ \\
\hline One & One & $\begin{array}{l}\text { Dissemination in space: } \\
\text { verified by MRI } \\
\text { or } \\
\text { verified by second clinical neurological attack } \\
\text { implicating a different CNS site } \\
\text { and } \\
\text { dissemination in time: } \\
\text { verified by MRI } \\
\text { or } \\
\text { verified by second clinical neurological attack }\end{array}$ \\
\hline $\begin{array}{l}\text { Neurological progression } \\
\text { suggestive of MS without } \\
\text { attacks (PPMS) }\end{array}$ & & 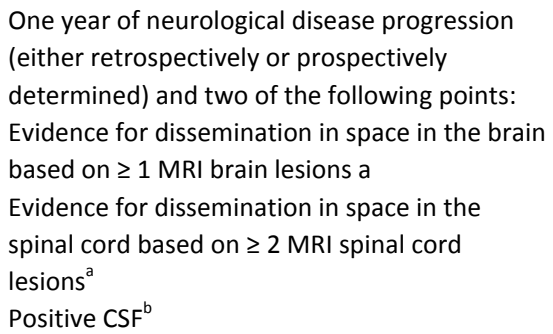 \\
\hline
\end{tabular}

a Verification by MRI must fulfil specific MRI criteria

b CSF is determined positive if oligoclonal bands are found in CSF

Abbreviations: CSF, cerebrospinal fluid; CNS, central nervous system; MS, multiple sclerosis; MRI, magnetic resonance imaging; PPMS, primary progressive multiple sclerosis. 


\section{CHAPTER 1}

\section{References}

1. Compston A, Coles A. Multiple sclerosis. Lancet 2008;372:1502-1517.

2. Orton SM, Herrera BM, Yee IM, et al. Sex ratio of multiple sclerosis in Canada: a longitudinal study. Lancet neurology 2006;5:932-936.

3. Gommer AM (RIVM) PMR. Multiple sclerose: prevalentie, incidentie en sterfte naar leeftijd en geslacht. In: Volksgezondheid Toekomst Verkenning, Nationaal Kompas Volksgezondheid. Bilthoven: RIVM, $<$ http://www.nationaalkompas.nl> Nationaal Kompas Volksgezondheid/Gezondheid en ziekte\Ziekten en aandoeningen\Zenuwstelsel en zintuigen\Multiple sclerose (MS) In: Milieu RvVe, ed., 13 december 2011.

4. Kurtzke JF. Rating neurologic impairment in multiple sclerosis: an expanded disability status scale (EDSS). Neurology 1983;33:1444-1452.

5. W.H.O. Atlas MS Web [online]. Available at: http://www.who.int/mental_health/neurology/Atlas_MS_WEB.pdf\%3e.

6. Goksel Karatepe A, Kaya T, Gunaydn R, Demirhan A, Ce P, Gedizlioglu M. Quality of life in patients with multiple sclerosis: the impact of depression, fatigue, and disability. Int J Rehabil Res 2011;34:290-298.

7. Rudick RA, Miller D, Clough JD, Gragg LA, Farmer RG. Quality of life in multiple sclerosis. Comparison with inflammatory bowel disease and rheumatoid arthritis. Arch Neurol 1992;49:1237-1242.

8. Leibowitz $\mathrm{U}$, Alter $\mathrm{M}$. Optic nerve involvement and diplopia as initial manifestations of multiple sclerosis. Acta Neurol Scand 1968;44:70-80.

9. McDonald WI, Barnes D. The ocular manifestations of multiple sclerosis. 1. Abnormalities of the afferent visual system. J Neurol Neurosurg Psychiatry 1992;55:747-752.

10. Sorensen TL, Frederiksen JL, Bronnum-Hansen H, Petersen HC. Optic neuritis as onset manifestation of multiple sclerosis: a nationwide, long-term survey. Neurology 1999;53:473-478.

11. Cole SR, Beck RW, Moke PS, Gal RL, Long DT. The National Eye Institute Visual Function Questionnaire: experience of the ONTT. Optic Neuritis Treatment Trial. Invest Ophthalmol Vis Sci 2000;41:1017-1021.

12. Graves J, Balcer L. Eye disorders in patients with multiple sclerosis: natural history and management. Clin Ophthalmol 2010;4:1409-1422.

13. Brodsky M, Nazarian S, Orengo-Nania S, et al. Multiple sclerosis risk after optic neuritis: final optic neuritis treatment trial follow-up. Arch Neurol 2008;65:727-732.

14. group ons. Visual function 15 years after optic neuritis: a final follow-up report from the Optic Neuritis Treatment Trial. Ophthalmology 2008;115:1079-1082 e1075.

15. Branas P, Jordan R, Fry-Smith A, Burls A, Hyde C. Treatments for fatigue in multiple sclerosis: a rapid and systematic review. Health technology assessment 2000;4:1-61.

16. Heesen C, Nawrath L, Reich C, Bauer N, Schulz KH, Gold SM. Fatigue in multiple sclerosis: an example of cytokine mediated sickness behaviour? J Neurol Neurosurg Psychiatry 2006;77:34-39.

17. Gottschalk $M$, Kumpfel $T$, Flachenecker $P$, et al. Fatigue and regulation of the hypothalamo-pituitaryadrenal axis in multiple sclerosis. Arch Neurol 2005;62:277-280.

18. Roelcke U, Kappos L, Lechner-Scott J, et al. Reduced glucose metabolism in the frontal cortex and basal ganglia of multiple sclerosis patients with fatigue: a 18F-fluorodeoxyglucose positron emission tomography study. Neurology 1997;48:1566-1571.

19. Tartaglia MC, Narayanan S, Francis SJ, et al. The relationship between diffuse axonal damage and fatigue in multiple sclerosis. Arch Neurol 2004;61:201-207.

20. Bol Y, Duits AA, Hupperts RM, Vlaeyen JW, Verhey FR. The psychology of fatigue in patients with multiple sclerosis: a review. J Psychosom Res 2009;66:3-11.

21. Kos D, Kerckhofs E, Nagels G, D'Hooghe M B, Ilsbroukx S. Origin of fatigue in multiple sclerosis: review of the literature. Neurorehabil Neural Repair 2008;22:91-100. 
22. Brown RF, Valpiani EM, Tennant CC, et al. Longitudinal assessment of anxiety, depression, and fatigue in people with multiple sclerosis. Psychol Psychother 2009;82:41-56.

23. Arnett PA, Barwick FH, Beeney JE. Depression in multiple sclerosis: review and theoretical proposal. J Int Neuropsychol Soc 2008;14:691-724.

24. Siegert RJ, Abernethy DA. Depression in multiple sclerosis: a review. J Neurol Neurosurg Psychiatry 2005;76:469-475.

25. Chwastiak L, Ehde DM, Gibbons LE, Sullivan M, Bowen JD, Kraft GH. Depressive symptoms and severity of illness in multiple sclerosis: epidemiologic study of a large community sample. Am J Psychiatry 2002;159:1862-1868.

26. Zabad RK, Patten SB, Metz LM. The association of depression with disease course in multiple sclerosis. Neurology 2005;64:359-360.

27. Bakshi R, Czarnecki D, Shaikh ZA, et al. Brain MRI lesions and atrophy are related to depression in multiple sclerosis. Neuroreport 2000;11:1153-1158.

28. Feinstein A, Roy $\mathrm{P}$, Lobaugh N, Feinstein $\mathrm{K}, \mathrm{O}^{\prime}$ Connor $\mathrm{P}$, Black S. Structural brain abnormalities in multiple sclerosis patients with major depression. Neurology 2004;62:586-590.

29. Gold SM, Kern KC, O'Connor MF, et al. Smaller cornu ammonis 2-3/dentate gyrus volumes and elevated cortisol in multiple sclerosis patients with depressive symptoms. Biol Psychiatry 2010;68:553559.

30. Kiy G, Lehmann P, Hahn HK, Eling P, Kastrup A, Hildebrandt H. Decreased hippocampal volume, indirectly measured, is associated with depressive symptoms and consolidation deficits in multiple sclerosis. Mult Scler 2011;17:1088-1097.

31. Gold SM, Kruger S, Ziegler KJ, et al. Endocrine and immune substrates of depressive symptoms and fatigue in multiple sclerosis patients with comorbid major depression. J Neurol Neurosurg Psychiatry 2011;82:814-818.

32. Pokryszko-Dragan A, Frydecka I, Kosmaczewska A, et al. Stimulated peripheral production of interferon-gamma is related to fatigue and depression in multiple sclerosis. Clin Neurol Neurosurg 2012.

33. Chiaravalloti ND, DeLuca J. Cognitive impairment in multiple sclerosis. Lancet Neurol 2008;7:11391151.

34. Reicker LI, Tombaugh TN, Walker L, Freedman MS. Reaction time: An alternative method for assessing the effects of multiple sclerosis on information processing speed. Arch Clin Neuropsychol 2007;22:655664.

35. Smestad C, Sandvik L, Landro NI, Celius EG. Cognitive impairment after three decades of multiple sclerosis. European journal of neurology : the official journal of the European Federation of Neurological Societies 2010;17:499-505.

36. Amato MP, Portaccio E, Goretti B, et al. Relevance of cognitive deterioration in early relapsing remitting MS: a 3-year follow-up study. Mult Scler 2010;16:1474-1482.

37. Calabrese M, Agosta F, Rinaldi F, et al. Cortical lesions and atrophy associated with cognitive impairment in relapsing-remitting multiple sclerosis. Arch Neurol 2009;66:1144-1150.

38. Cifelli A, Arridge M, Jezzard P, Esiri MM, Palace J, Matthews PM. Thalamic neurodegeneration in multiple sclerosis. Ann Neurol 2002;52:650-653.

39. Popescu BF, Bunyan RF, Parisi JE, Ransohoff RM, Lucchinetti CF. A case of multiple sclerosis presenting with inflammatory cortical demyelination. Neurology 2011;76:1705-1710.

40. Polman $\mathrm{CH}$, Reingold SC, Banwell B, et al. Diagnostic criteria for multiple sclerosis: 2010 revisions to the McDonald criteria. Ann Neurol 2011;69:292-302.

41. Schaffler N, Kopke S, Winkler L, et al. Accuracy of diagnostic tests in multiple sclerosis--a systematic review. Acta Neurol Scand 2011;124:151-164.

42. Chiappa KH. Use of evoked potentials for diagnosis of multiple sclerosis. Neurologic clinics 1988;6:861880. 


\section{CHAPTER 1}

43. Petzold A, de Boer JF, Schippling S, et al. Optical coherence tomography in multiple sclerosis: a systematic review and meta-analysis. Lancet Neurol 2010;9:921-932.

44. Fu Y, Talavage TM, Cheng JX. New imaging techniques in the diagnosis of multiple sclerosis. Expert Opin Med Diagn 2008;2:1055-1065.

45. Fisher JB, Jacobs DA, Markowitz CE, et al. Relation of visual function to retinal nerve fiber layer thickness in multiple sclerosis. Ophthalmology 2006;113:324-332.

46. Costello F, Hodge W, Pan YI, Eggenberger E, Freedman MS. Using retinal architecture to help characterize multiple sclerosis patients. Can J Ophthalmol 2010;45:520-526.

47. Siger M, Dziegielewski K, Jasek L, et al. Optical coherence tomography in multiple sclerosis: thickness of the retinal nerve fiber layer as a potential measure of axonal loss and brain atrophy. J Neurol 2008;255:1555-1560.

48. Bar-Or A, Rieckmann P, Traboulsee A, Yong VW. Targeting progressive neuroaxonal injury: lessons from multiple sclerosis. CNS drugs 2011;25:783-799.

49. Frohman EM, Racke MK, Raine CS. Multiple sclerosis--the plaque and its pathogenesis. The New England journal of medicine 2006;354:942-955.

50. Khoruts A, Miller SD, Jenkins MK. Neuroantigen-specific Th2 cells are inefficient suppressors of experimental autoimmune encephalomyelitis induced by effector Th1 cells. Journal of immunology 1995;155:5011-5017.

51. Jager A, Dardalhon V, Sobel RA, Bettelli E, Kuchroo VK. Th1, Th17, and Th9 effector cells induce experimental autoimmune encephalomyelitis with different pathological phenotypes. Journal of immunology 2009;183:7169-7177.

52. O'Connor RA, Prendergast CT, Sabatos CA, et al. Cutting edge: Th1 cells facilitate the entry of Th17 cells to the central nervous system during experimental autoimmune encephalomyelitis. Journal of immunology 2008;181:3750-3754.

53. Bar-Or A. The immunology of multiple sclerosis. Semin Neurol 2008;28:29-45.

54. Goverman J. Autoimmune $T$ cell responses in the central nervous system. Nat Rev Immunol 2009;9:393-407.

55. Venken K, Hellings $\mathrm{N}$, Hensen $\mathrm{K}$, et al. Secondary progressive in contrast to relapsing-remitting multiple sclerosis patients show a normal $\mathrm{CD} 4^{+} \mathrm{CD} 25^{+}$regulatory T-cell function and FOXP3 expression. Journal of neuroscience research 2006;83:1432-1446.

56. Viglietta V, Baecher-Allan C, Weiner HL, Hafler DA. Loss of functional suppression by $\mathrm{CD} 4^{+} \mathrm{CD} 25^{+}$ regulatory T cells in patients with multiple sclerosis. J Exp Med 2004;199:971-979.

57. Esiri MM. Multiple sclerosis: a quantitative and qualitative study of immunoglobulin-containing cells in the central nervous system. Neuropathology and applied neurobiology 1980;6:9-21.

58. Hauser SL, Waubant E, Arnold DL, et al. B-cell depletion with rituximab in relapsing-remitting multiple sclerosis. The New England journal of medicine 2008;358:676-688.

59. Dalakas MC. B cells as therapeutic targets in autoimmune neurological disorders. Nature clinical practice. Neurology 2008;4:557-567.

60. Bar-Or A, Fawaz L, Fan B, et al. Abnormal B-cell cytokine responses a trigger of T-cell-mediated disease in MS? Ann Neurol 2010;67:452-461.

61. Haas J, Bekeredjian-Ding I, Milkova $M$, et al. B cells undergo unique compartmentalized redistribution in multiple sclerosis. J Autoimmun 2011;37:289-299.

62. Lee-Chang $\mathrm{C}$, Zephir H, Top I, et al. B-cell subsets up-regulate alpha4 integrin and accumulate in the cerebrospinal fluid in clinically isolated syndrome suggestive of multiple sclerosis onset. Neurosci Lett 2011;487:273-277.

63. Magliozzi R, Howell $\mathrm{O}$, Vora A, et al. Meningeal B-cell follicles in secondary progressive multiple sclerosis associate with early onset of disease and severe cortical pathology. Brain 2007;130:10891104. 
64. Wolf SD, Dittel BN, Hardardottir F, Janeway CA, Jr. Experimental autoimmune encephalomyelitis induction in genetically B cell-deficient mice. J Exp Med 1996;184:2271-2278.

65. Matsushita T, Horikawa M, Iwata Y, Tedder TF. Regulatory B cells (B10 cells) and regulatory T cells have independent roles in controlling experimental autoimmune encephalomyelitis initiation and late-phase immunopathogenesis. Journal of immunology 2010;185:2240-2252.

66. Hirotani M, Niino M, Fukazawa T, et al. Decreased IL-10 production mediated by Toll-like receptor 9 in B cells in multiple sclerosis. Journal of neuroimmunology 2010;221:95-100.

67. Mikol DD, Barkhof F, Chang P, et al. Comparison of subcutaneous interferon beta-1a with glatiramer acetate in patients with relapsing multiple sclerosis (the REbif vs Glatiramer Acetate in Relapsing MS Disease [REGARD] study): a multicentre, randomised, parallel, open-label trial. Lancet neurology 2008;7:903-914.

68. Jeffery DR, Herndon R. Review of mitoxantrone in the treatment of multiple sclerosis. Neurology 2004;63:S19-24.

69. Polman $\mathrm{CH}, \mathrm{O}^{\prime}$ Connor PW, Havrdova E, et al. A randomized, placebo-controlled trial of natalizumab for relapsing multiple sclerosis. The New England journal of medicine 2006;354:899-910.

70. Rudick RA, Stuart WH, Calabresi PA, et al. Natalizumab plus interferon beta-1a for relapsing multiple sclerosis. The New England journal of medicine 2006;354:911-923.

71. Cohen JA, Barkhof F, Comi G, et al. Oral fingolimod or intramuscular interferon for relapsing multiple sclerosis. The New England journal of medicine 2010;362:402-415.

72. Kappos L, Radue EW, O'Connor P, et al. A placebo-controlled trial of oral fingolimod in relapsing multiple sclerosis. The New England journal of medicine 2010;362:387-401.

73. Pelletier D, Hafler DA. Fingolimod for multiple sclerosis. The New England journal of medicine 2012;366:339-347.

74. Kieseier BC, Stuve O. A critical appraisal of treatment decisions in multiple sclerosis--old versus new. Nature reviews. Neurology 2011;7:255-262.

75. CBOrichtlijn. Conceptrichtlijn Diagnostiek, behandeling en functioneren bij Multiple sclerose In, 2011.

76. Munger KL, Levin LI, Hollis BW, Howard NS, Ascherio A. Serum 25-hydroxyvitamin D levels and risk of multiple sclerosis. JAMA : the journal of the American Medical Association 2006;296:2832-2838.

77. Ascherio A, Munger KL, Simon KC. Vitamin D and multiple sclerosis. Lancet Neurol 2010;9:599-612.

78. Smolders J, Damoiseaux J, Menheere P, Hupperts R. Vitamin D as an immune modulator in multiple sclerosis, a review. Journal of neuroimmunology 2008;194:7-17.

79. Mowry EM, Krupp LB, Milazzo M, et al. Vitamin D status is associated with relapse rate in pediatriconset multiple sclerosis. Annals of neurology 2010;67:618-624.

80. Simpson S, Jr., Taylor B, Blizzard L, et al. Higher 25-hydroxyvitamin D is associated with lower relapse risk in multiple sclerosis. Annals of neurology 2010;68:193-203.

81. Smolders J, Hupperts R, Barkhof F, et al. Efficacy of vitamin D(3) as add-on therapy in patients with relapsing-remitting multiple sclerosis receiving subcutaneous interferon beta-1a: a Phase II, multicenter, double-blind, randomized, placebo-controlled trial. J Neurol Sci 2011;311:44-49.

82. Soilu-Hanninen M, Aivo J, Lindstrom BM, et al. A randomised, double blind, placebo controlled trial with vitamin D3 as an add on treatment to interferon beta- $1 \mathrm{~b}$ in patients with multiple sclerosis. J Neurol Neurosurg Psychiatry 2012;83:565-571.

83. Knapp AA. The eye as a guide to latent nutritional deficiency diseases; a clinical study of ocular diseases at an advanced base hospital in the Southwest Pacific. Bull N Y Acad Med 1946;22:217-222.

84. Ruiz-Irastorza G, Egurbide MV, Olivares N, Martinez-Berriotxoa A, Aguirre C. Vitamin D deficiency in systemic lupus erythematosus: prevalence, predictors and clinical consequences. Rheumatology (Oxford) 2008;47:920-923.

85. Ruiz-Irastorza G, Gordo S, Olivares N, Egurbide MV, Aguirre C. Changes in vitamin D levels in patients with systemic lupus erythematosus: Effects on fatigue, disease activity, and damage. Arthritis Care Res (Hoboken) 2008;62:1160-1165. 


\section{CHAPTER 1}

86. Buell JS, Scott TM, Dawson-Hughes B, et al. Vitamin D is associated with cognitive function in elders receiving home health services. J Gerontol A Biol Sci Med Sci 2009;64:888-895.

87. Llewellyn DJ, Lang IA, Langa KM, et al. Vitamin $D$ and risk of cognitive decline in elderly persons. Arch Intern Med 2010;170:1135-1141.

88. Oudshoorn C, Mattace-Raso FU, van der Velde N, Colin EM, van der Cammen TJ. Higher serum vitamin D3 levels are associated with better cognitive test performance in patients with Alzheimer's disease. Dement Geriatr Cogn Disord 2008;25:539-543.

89. Ganji V, Milone C, Cody MM, McCarty F, Wang YT. Serum vitamin D concentrations are related to depression in young adult US population: the Third National Health and Nutrition Examination Survey. Int Arch Med 2010;3:29.

90. Jorde R, Sneve M, Figenschau $Y$, Svartberg J, Waterloo K. Effects of vitamin D supplementation on symptoms of depression in overweight and obese subjects: randomized double blind trial. J Intern Med 2008;264:599-609.

91. May HT, Bair TL, Lappe DL, et al. Association of vitamin D levels with incident depression among a general cardiovascular population. Am Heart J 2010;159:1037-1043. 


\section{Chapter 2}

\section{Effects of vitamin D on the peripheral adaptive immune system}

Published as: Stephanie Knippenberg, Evelyn Peelen, Anne-Hilde Muris, Mariëlle Thewissen, Joost Smolders, Raymond Hupperts, Jan Willem Cohen Tervaert, Jan Damoiseaux. 'Effects of vitamin D on the peripheral adaptive immune system: a review'. Autoimmunity Reviews,. 2011 Oct;10(12):733-43. 


\title{
CHAPTER 2
}

\begin{abstract}
Epidemiological studies have shown that a poor vitamin D status is associated with an increased risk of several diseases, including autoimmune diseases. The immune regulatory function of vitamin $\mathrm{D}$ is thought to have an important role in these associations. Cells of the adaptive immune system have shown to be direct targets of the vitamin $D$ metabolites. Besides being direct targets, cells of the adaptive immune system express the enzymes involved in the metabolism of vitamin $D$, enabling them to locally convert $25(\mathrm{OH}) \mathrm{D}$ into its active metabolite $1,25(\mathrm{OH})_{2} \mathrm{D}$. In this review, the effects of vitamin $\mathrm{D}$ on cells of the adaptive immune system are described. Experimental data in vitro show that vitamin D skews cells of the adaptive immune system toward a more tolerogenic status which might be exploited in the treatment of autoimmune diseases. However, it should be noticed that in vivo effects may differ from in vitro effects due to the crosstalk between different vitamin D sensitive cells, but data support the view that vitamin $D$ is positively involved in maintaining or restoring immune homeostasis. Upcoming vitamin $D$ supplementation trials will further elucidate the in vivo effects of vitamin $D$ on the immune system and its potency to serve as an immune regulating agent in autoimmune diseases.
\end{abstract}




\section{Introduction}

Vitamin $D$ is increasingly recognized as an important immune modulating agent. As a consequence, a poor vitamin $D$ status is associated with a higher risk of numerous diseases, such as cancer [1-3] and cardiovascular diseases [4, 5]. Also, a large number of autoimmune diseases have been associated with a poor vitamin D status, including multiple sclerosis (MS) [6], diabetes mellitus type I [7], systemic lupus erythematosus (SLE) [8], vasculitis [9], rheumatoid arthritis (RA) [10] and other autoimmune rheumatological disorders [11].

Vitamin $D_{3}$ is mainly synthesized in the skin upon exposure to UVB radiation (sunlight), while only a small fraction $(<5 \%)$ is obtained via our dietary intake of dairy products and dark fish [12, 13]. Vitamin D has a half-life of 12-16 hours and is biologically inactive [14]. To become biologically active, it is converted to $25(\mathrm{OH}) \mathrm{D}$, by a member of the cytochrome P family (CyP), the 25-hydroxylases (CyP2R1, CyP27A1 and CyP3A4), which are mainly expressed in the liver, to its metabolite 25-hydroxyvitamin D (25(OH)D). 25(OH)D needs another hydroxylation by 1- $\alpha$-hydroxylase (CyP27B1), predominantly expressed in the kidneys, to be converted to the biologically active form 1,25-dihydroxyvitamin $\mathrm{D}\left(1,25(\mathrm{OH})_{2} \mathrm{D}\right)$, also known as calcitriol. Excessive amounts of $1,25(\mathrm{OH})_{2} \mathrm{D}$ are catalyzed by 24-hydoxylase (Cyp24A1) and excreted by the kidneys [15]. Binding of $1,25(\mathrm{OH})_{2} \mathrm{D}$ to the intracellular vitamin $\mathrm{D}$ receptor (VDR) modulates the expression of up to 500 genes [16-18]. It has been shown that resting monocytes and dendritic cells (DC) express the VDR intracellularly [19-22], while resting $T$ and $B$ lymphocytes express little to no VDR $[21,23]$. However, when activated, the VDR expression by lymphocytes is up-regulated $[21,23]$. Importantly, next to the kidney, many peripheral blood mononuclear cells (PBMC), including monocytes, DC, $\mathrm{CD}^{+} \mathrm{T}$ cells, CD8 ${ }^{+} \mathrm{T}$ cells and B cells, express CyP27B1 and CyP24A1 [20, 24-30]. Although the hydroxylation of $25(\mathrm{OH}) \mathrm{D}$ by PBMC is only modest compared to systemic hydroxylation by the kidneys, it is important for the local activation of 25(OH)D in the tissues and at sites of inflammation. Furthermore, the expression of VDR, CyP27B1 and CyP24A1, indicates that the availability and effectivity of $1,25(\mathrm{OH})_{2} \mathrm{D}$ can be strictly regulated by the cells of the immune system.

In this review, we focus on the effects of vitamin D metabolites and vitamin $D$ analogs on cells of the peripheral adaptive immune system, i.e. T and B lymphocytes. Since antigen presenting cells (APC), like monocytes and DC, are the gate-keepers of the adaptive immune response these cells will also be included, as well as the third lymphocyte population, the natural killer $(T)$ cells. Although the latter cells are part of the innate immune system, they are increasingly recognized as important players in adaptive immune regulation [31]. 


\section{CHAPTER 2}

\section{Effects of vitamin D on antigen presenting cells}

Monocytes and in particular DC represent APC which are important in the initiation of the adaptive immune response. Both cell types can be either immunogenic or tolerogenic and hereby modulate T cell responses [32, 33]. Tolerogenic APC are characterized by a reduced expression of co-stimulatory molecules and a cytokine production favouring regulatory $T$ cell (Treg) induction [34]. Vitamin D has been shown to manipulate monocytes and DC at different levels enabling them to exert tolerogenic activities, which could be exploited to better control autoimmune diseases [35]. Since research in mice mainly explored the innate functions of monocytes, data discussed in this section were all obtained in humans. Both, resting monocytes and resting DC express VDR. Hence, they are direct targets of $1,25(\mathrm{OH})_{2} \mathrm{D}$ [19-22]. Monocytes cultured with $1,25(\mathrm{OH})_{2} \mathrm{D}$ display a VDR-dependent loss of MHC-II [22]. Surface co-stimulatory molecules, such as CD40, CD80 and CD86 are also reduced upon culture with $1,25(\mathrm{OH})_{2} \mathrm{D}$ [36]. The altered monocyte phenotype affects the $\mathrm{T}$ cell stimulatory capacity of these APC. Indeed, monocytes pre-treated with $1,25(\mathrm{OH})_{2} \mathrm{D}$ were less effective in inducing proliferation of $\mathrm{T}$ cells upon stimulation with tetanus toxoid [22]. Additionally, $1,25(\mathrm{OH})_{2} \mathrm{D}$ inhibits the production of IL- $1 \alpha, \mathrm{IL}-6, \mathrm{IL}-12$ and TNF- $\alpha$ by monocytes cultured in the presence of pro-inflammatory stimuli such as CD4OL and LPS [32, 36-38]. On the other hand, transcription levels of IL-10 mRNA are significantly up-regulated by LPS stimulated monocytes in the presence of $1,25(\mathrm{OH})_{2} \mathrm{D}$ [39]. Also in vivo, $1,25(\mathrm{OH})_{2} \mathrm{D}$ treatment ( $1 \mu \mathrm{g}$ twice daily for 7 days) in healthy volunteers showed a significant reduction in IL-6, but not IL-1 $\alpha$ or TNF- $\alpha$ production by PBMC [40]. The cytokines affected by $1,25(\mathrm{OH})_{2} \mathrm{D}$ are typically involved in the differentiation of naïve $\mathrm{T}$ cells in distinct effector helper $\mathrm{T}$ cell subsets. For instance, monocytes activated in the presence of $1,25(\mathrm{OH})_{2} \mathrm{D}$ and co-cultured with anti-CD3 stimulated purified $\mathrm{CD}^{+} \mathrm{T}$ cells, show a decreased IFN- $\gamma$ and increased IL-10 production by $\mathrm{CD}^{+}{ }^{+} \mathrm{T}$ cells. Furthermore, IL- 6 has been described to prevent the development of TGF- $\beta$ induced Tregs and to interact with TGF- $\beta$ to induce Th17 cell differentiation [41]. Thus, by decreasing IL-6 production and by increasing IL-10 production in monocytes, vitamin D could modulate the T cell response in a more anti-inflammatory and regulatory direction. Effects of vitamin $D$ on monocytes are summarized in Table $1 \mathrm{~A}$.

Monocytes can differentiate into immature DC when cultured with GM-CSF and IL$4[42,43]$. These DC show functional and phenotypical characteristics of the immature stage: a high capacity of antigen uptake and processing but a low capacity to stimulate $T$ cell proliferation. Immature DC can be further differentiated in vitro into mature DC with TNF- $\alpha$, LPS, IL-1, or CD40L [44-46]. The differentiation of monocytes into immature $\mathrm{DC}$ is inhibited by $1,25(\mathrm{OH})_{2} \mathrm{D}$ as characterized by a sustained $\mathrm{CD} 14$ expression and inability to up-regulate CD1a [45-47]. Exposure of immature $D C$ to $1,25(\mathrm{OH})_{2} \mathrm{D}$ may even restore the monocytic phenotype [46]. The inhibition of DC maturation by $1,25(\mathrm{OH})_{2} \mathrm{D}$ is also reflected by the maintained expression of immature DC markers, 
CD32 and mannose receptor [46]. The preserved mannose receptor correlates well with an increased endocytotic capacity of the $1,25(\mathrm{OH})_{2} \mathrm{D}$ modulated DC [46]. Additionally, pre-treated immature $\mathrm{DC}$ show an inability to up-regulate maturation markers involved in antigen presentation [45-48]. DC, which were matured in vitro in the presence of $1,25(\mathrm{OH})_{2} \mathrm{D}$, have an altered cytokine and chemokine profile. The release of Th1 and Th17 inducing cytokines, IL-12 and IL-23, is inhibited, while the production of IL-10 and CCL22, involved in Treg and Th2 immune responses, respectively, is enhanced [20, 45-47]. In line with the observed effects on DC, 1,25(OH) 2 D modulated DC have a reduced capacity to trigger $\mathrm{T}$ cell proliferation as established in a mixed lymphocyte reaction $[45,46,49]$. Moreover, $\mathrm{T}$ cells cultured with $1,25(\mathrm{OH})_{2} \mathrm{D}$ pre-treated $D C$, become hypo-responsive after re-exposure to untreated mature $D C[45,46]$. This might be due to the induction of $\mathrm{CD}^{+}{ }^{+} \mathrm{FoxP}^{+}$Tregs [50-52], or alternatively IL-10 producing $\operatorname{Tr} 1$ cells. In humans, 2 different $D C$ subsets are identified, plasmacytoid DC ( $p$ $\mathrm{DC}$ ) and myeloid $\mathrm{DC}(\mathrm{m}-\mathrm{DC})$ [53]. Exposure of blood-isolated p-DC to $1,25(\mathrm{OH})_{2} \mathrm{D}$ ex vivo, had negligible effects on the phenotype and functionality of $\mathrm{p}-\mathrm{DC}$. However, $\mathrm{m}$ $\mathrm{DC}$ showed a marked reduction in IL-12 production and MHC-II expression after culture with $1,25(\mathrm{OH})_{2} \mathrm{D}[20]$. Altogether these results show that $1,25(\mathrm{OH})_{2} \mathrm{D}$ can block $\mathrm{DC}$ maturation, abrogate IL-12 production and strongly enhance production of IL-10 (Table 1B). These effects explain the capacity of $1,25(\mathrm{OH})_{2} \mathrm{D}$ to induce $\mathrm{DC}$ with tolerogenic properties which favour Treg development. Therefore, vitamin D modulated DC might be useful in future therapies to reestablish immune tolerance in transplantation or autoimmune diseases. 
CHAPTER 2

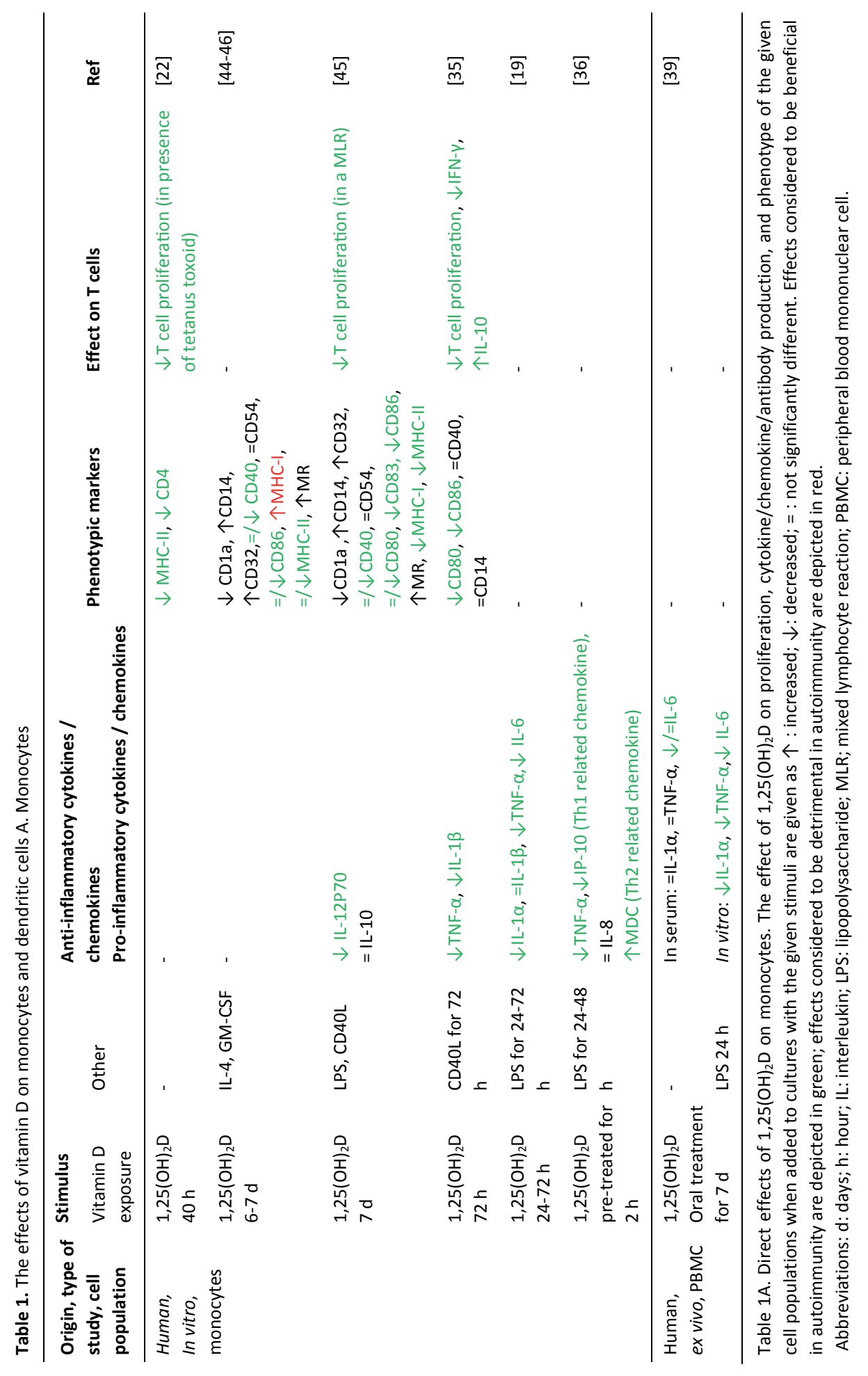


VITAMIN D AND THE PERIPHERAL ADAPTIVE IMMUNE SYSTEM

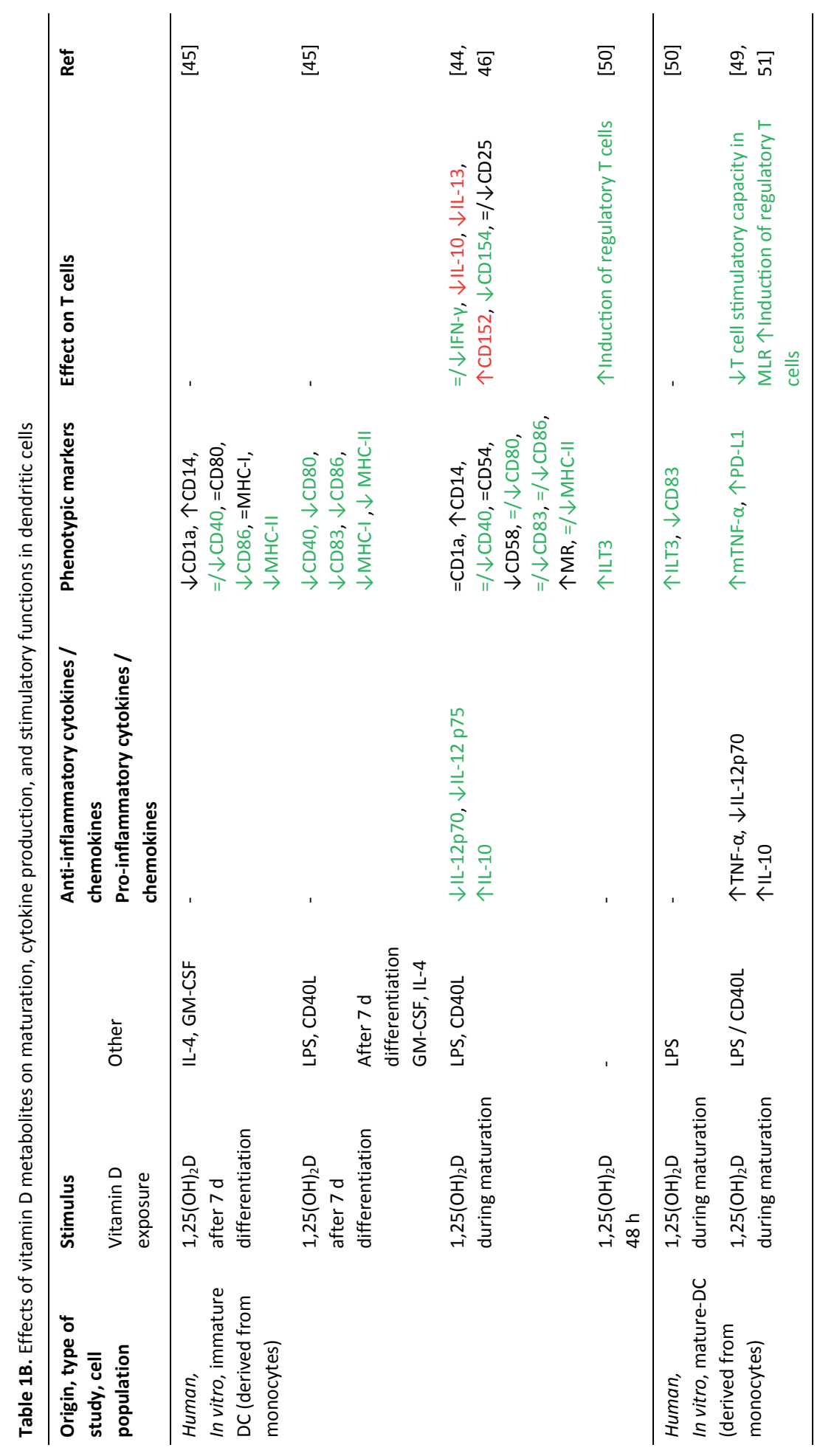


CHAPTER 2

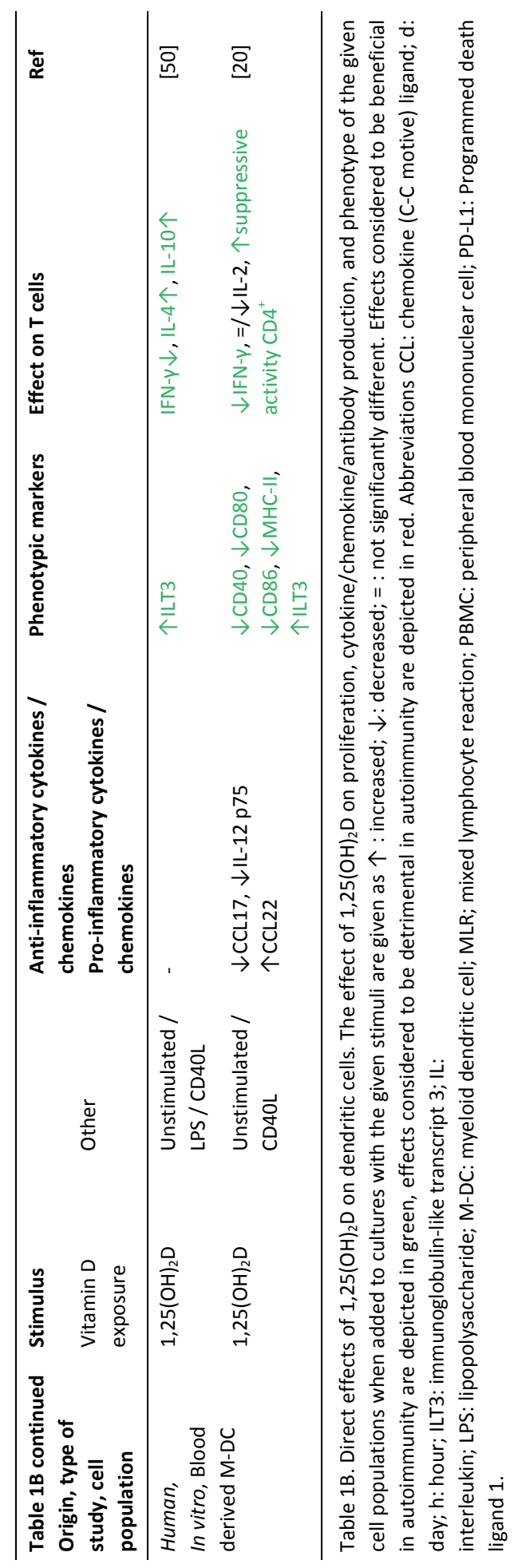




\section{Effects of vitamin D on T cells}

Numerous studies have described effects of $1,25(\mathrm{OH})_{2} \mathrm{D}$ on $\mathrm{T}$ cell responses. These effects may be attributable to the earlier described effects of $1,25(\mathrm{OH})_{2} \mathrm{D}$ on APC function. Nevertheless, $T$ cells are also direct target of $1,25(\mathrm{OH})_{2} \mathrm{D}$ since they have been demonstrated to express VDR, in particular upon activation [21, 23, 25, 54]. Discriminating between direct and indirect effects of $1,25(\mathrm{OH})_{2} \mathrm{D}$ on $\mathrm{T}$ cell function is difficult, but in vitro studies did provide some insight in this. Here, we will discuss the overall effects of $1,25(\mathrm{OH})_{2} \mathrm{D}$ on distinct $\mathrm{T}$ cell subsets; data, including details on stimulation conditions, are summarized in Table 2.

\section{$T$ helper cells (CD4 ${ }^{+} T$ cells)}

In vitro proliferation of murine $\mathrm{CD}^{+} \mathrm{T}$ cells is either inhibited or not affected by $1,25(\mathrm{OH})_{2} \mathrm{D}[23,55-57]$. A single study reported promotion of proliferation upon stimulation with concanavalin A, but this involved a CD4 T cell line, while the other studies used freshly isolated lymphocytes. Proliferation of human $\mathrm{CD}^{+} \mathrm{T}$ cells is consistently inhibited by $1,25(\mathrm{OH})_{2} \mathrm{D}[25,58-60]$, although this effect is limited when a strong stimulus, like anti-CD3 combined with anti-CD28, is applied [58,60]. It may be possible that in these culture conditions the tolerogenic effect of $1,25(\mathrm{OH})_{2} \mathrm{D}$ on APC is important for inhibiting $\mathrm{T}$ cell proliferation.

In line with the effects on proliferation, IL-2 production is inhibited by $1,25(\mathrm{OH})_{2} \mathrm{D}$ in both mice and human $\mathrm{CD}^{+} \mathrm{T}$ cells $[56,58,61,62]$. This effect is observed independent of the type of stimulation and the presence or absence of monocytes. Contradicting results of $1,25(\mathrm{OH})_{2} \mathrm{D}$ on IL-6 production have been observed. Correale et al. described a reduction in the percentage of IL- 6 producing $\mathrm{CD} 4^{+} \mathrm{T}$ cells in healthy controls as well as in relapsing remitting MS (RRMS) patients [25], whereas other groups showed an increase in IL- 6 producing CD4 ${ }^{+}$T cells and elevated levels of IL- 6 secretion by $\mathrm{CD}^{+} \mathrm{T}$ cells in both healthy individuals as well as patients with Crohn's disease [62, 63]. This difference might be explained by differences in the experimental methods used.

Finally, $\mathrm{CD}^{+} \mathrm{T}$ cells pre-incubated with $1,25(\mathrm{OH})_{2} \mathrm{D}$ were less efficient in the crosstalk with $B$ cells. In co-cultures stimulated with pokeweed mitogen the secretion of IgG and IgM was inhibited [59].

\section{Thelper 1 cells}

For studying T helper 1 cells (Th1), interferon- $\nu$ (IFN- $-\gamma$ ) is considered the prototypic cytokine. The in vitro effect of $1,25(\mathrm{OH})_{2} \mathrm{D}$ on IFN- $\gamma$ production by murine $\mathrm{CD}^{+}{ }^{+} \mathrm{T}$ cells, i.e. Th1 cells, are somewhat contradicting due to differences in stimulation conditions and type of effector cells analysed. $1,25(\mathrm{OH})_{2} \mathrm{D}$ either reduces the IFN- $\gamma$ production by $\mathrm{CD}^{+} \mathrm{T}$ cells $[56,57,64-67]$, or has no effect $[57,66-69]$. As the case for T cell proliferation, the effects of $1,25(\mathrm{OH})_{2} \mathrm{D}$ on IFN- $\gamma$ production, might be dependent on the 


\section{CHAPTER 2}

strength of the stimulation in combination with the presence or absence of APC. Therefore, it is tempting to speculate that this also holds for IFN- $\psi$ production. The inhibiting effect of $1,25(\mathrm{OH})_{2} \mathrm{D}$ involves both the differentiation into Th1 cells as well as the cytokine production by Th1 cells [56, 57, 64-67]. These effects might be direct effects on the T cells since Th1 cells do express the VDR, although far less than other polarized T cell subsets $[67,69,70]$.

Most in vitro studies on human $\mathrm{CD}^{+} \mathrm{T}$ cells show that $1,25(\mathrm{OH})_{2} \mathrm{D}$ is able to reduce IFN- $\gamma$ secretion and IFN $-\gamma^{+} \mathrm{CD} 4^{+} \mathrm{T}$ cell numbers. This is at least partially a direct effect on $\mathrm{T}$ cells, because this reduction was observed both with $\mathrm{CD}^{+} \mathrm{T}$ cells cultured with monocytes as well as with pure $\mathrm{CD}^{+}{ }^{\mathrm{T}}$ cells $[58,63,66,71]$. However, Correale et al. did not observe an effect of $1,25(\mathrm{OH})_{2} \mathrm{D}$ on the number of IFN- $\gamma$ secreting $\mathrm{CD} 4^{+} \mathrm{T}$ cells from healthy controls and MS patients [25]. Nevertheless, they observed a reduction of IFN$\checkmark$ protein levels in culture supernatants of $\mathrm{CD}^{+} \mathrm{T}$ cells cultured under Th1 polarizing conditions in the presence of $1,25(\mathrm{OH})_{2} \mathrm{D}$ [25]. Two studies reported no effect of $1,25(\mathrm{OH})_{2} \mathrm{D}$ on IFN $-\gamma^{+} \mathrm{CD} 4^{+} \mathrm{T}$ cell percentages $[61,62]$. In these two studies, PBMC were stimulated with $\mathrm{PHA}$, in contrast to the anti-CD28 and/or anti-CD3 stimulations used in the studies mentioned before.

The in vivo effect of $1,25(\mathrm{OH})_{2} \mathrm{D}$ on $\mathrm{T}$ cell function has been studied in mouse models of various autoimmune diseases. In line with the in vitro data, several studies showed an inhibition in IFN- $\gamma$ secretion, whereas others described no effect $[72,73]$. Our group showed a trend towards a negative association between in vivo serum 25(OH)D levels and the fraction IFN $-\gamma^{+} \mathrm{CD} 4^{+} \mathrm{T}$ cells in RRMS patients [74]. In Behçet patients with active disease showed a negative correlation between the serum 25(OH)D levels and the fraction IFN- $\gamma^{+} \mathrm{CD}^{+}$T cells [75]. Putting things together, the most consistent effect of $1,25(\mathrm{OH})_{2} \mathrm{D}$ is the inhibition of Th1 cells.

\section{Thelper 2 cells}

The prototypic cytokine for Th2 cells is IL-4. Importantly, murine T helper 2 cells (Th2) cells are reported to consistently express relatively high levels of VDR and therefore these cells can respond directly to $1,25(\mathrm{OH})_{2} \mathrm{D}[67,70]$. Stimulation of murine $T$ cells in the presence of $1,25(\mathrm{OH})_{2} \mathrm{D}$ results in an increased production of IL-4 or an increased percentage of IL- $4^{+} \mathrm{CD} 4^{+} \mathrm{T}$ cells $[56,57,65,66]$. Other studies could, however, not confirm these findings $[57,64,67]$, probably due to differences in culture conditions. Th2 enhancing effects were observed both in the presence as well as the absence of APC. Interestingly, under Th2 polarizing conditions, $1,25(\mathrm{OH})_{2} \mathrm{D}$ seems to inhibit Th2 differentiation of mouse $\mathrm{CD}^{+} \mathrm{T}$ cells $[57,67]$.

In vitro studies with human $\mathrm{CD}^{+}{ }^{+}$cells show conflicting data with regard to the effects on Th2 cells. Some studies show an increase in IL-4 producing CD4 ${ }^{+} \mathrm{T}$ cells or IL4 secretion by $\mathrm{CD}^{+} \mathrm{T}$ cells cultured in the presence of $1,25(\mathrm{OH})_{2} \mathrm{D}[58,63]$, while others observed no effect $[25,61,62]$, or even a decrease [76]. These inconsistencies on the in vitro effects of $1,25(\mathrm{OH})_{2} \mathrm{D}$ on human Th2 differentiation and function could be 
caused by the differences in the experimental design used, i.e. the use of Th2 polarizing conditions, type and duration of stimulation and type of cells used (see Table 2). Studies investigating the in vivo effects of $1,25(\mathrm{OH})_{2} \mathrm{D}$ on peripheral Th2 cells in mice are, to our knowledge, lacking. Our group found no association between the percentage of Th2 cells and serum 25(OH)D levels in RRMS patients [74]. Overall, it seems that $1,25(\mathrm{OH})_{2} \mathrm{D}$ is able to inhibit Th2 cell differentiation, but enhances the secretion of IL-4 by already differentiated Th2 cells.

\section{Thelper 17 cells}

Like murine Th2 cells, murine T helper 17 cells (Th17) cells have a relatively high expression of the VDR $[69,70]$. In in vitro studies with murine T cells, $1,25(\mathrm{OH})_{2} \mathrm{D}$ consistently reduces the expression of IL-17, the marker cytokine for Th17 cells [66, 68-70]. These observations are independent of the antigen or type of stimulation used. Similar results are obtained with human cells, including purified $\mathrm{CD4}^{+} \mathrm{T}$ cells $[25,58,66,71$, 76]. Also other molecules typically expressed by Th17 cells, like IL-21 and RORyt, are downregulated by $1,25(\mathrm{OH})_{2} \mathrm{D}[58,66,70,71]$.

Production of IL-22, which may be a product of Th17 cells or the recently described Th22 cells, is consistently reduced by $1,25(\mathrm{OH})_{2} \mathrm{D}$ in both murine and human studies $[66,69,71]$.

Two murine experimental autoimmune encephalomyelitis (EAE) studies, however, reveal conflicting results, possibly explained by a difference in time of analyses after induction of disease $[68,73]$. In RRMS patients, no association between serum 25(OH)D levels and Th17 cell percentages was observed [74]. Surprisingly, Th17 cell percentages did correlated with serum $1,25(\mathrm{OH})_{2} \mathrm{D}$ levels in the same RRMS patient cohort [77]. Hamzaoui et al. observed a negative correlation between serum 25(OH)D levels and the fraction of $\mathrm{IL}-17^{+} \mathrm{CD4}^{+} \mathrm{T}$ cells in Behçet patients during active disease [75]. It can be concluded that in vitro $1,25(\mathrm{OH})_{2} \mathrm{D}$ is able to decrease the fraction of Th17 cells and the expression and secretion of IL-17. In vivo effects of $1,25(\mathrm{OH})_{2} \mathrm{D}$, however, are conflicting.

\section{Regulatory $T$ cells}

Although it is well established that several distinct subsets of Treg exist, two molecules are widely accepted as markers for Treg, i.e. the transcription factor FoxP3 and the cytokine IL-10. The former is preferentially expressed by natural Treg (nTreg) cells, which were originally identified as $\mathrm{CD} 25^{\text {high }}$ and later as $\mathrm{CD} 25^{+} \mathrm{CD} 127^{\text {low }} \mathrm{CD} 4^{+} \mathrm{T}$ cells. IL10 is, on the other hand, characteristic for Tr1 cells, a subset of inducible Treg (iTreg). Two studies in mice addressed the effect of $1,25(\mathrm{OH})_{2} \mathrm{D}$ on the expansion of FoxP3 ${ }^{+}$ Treg under Treg polarizing conditions, i.e. T cell stimulation in the presence of TGF- $\beta$. In one study, $1,25(\mathrm{OH})_{2} \mathrm{D}$ inhibited the expansion of $\mathrm{FoxP}^{+} \mathrm{T}$ cells [68], while the other study did not show an effect [73]. However, for interpretation of these data it is important to realize that FoxP3 may also be induced in iTreg, and therefore these studies 


\section{CHAPTER 2}

do not differentiate between natural and inducible Treg. With respect to iTreg, several studies consistently reveal increased IL-10 secretion and/or IL- $10^{+} \mathrm{CD} 4^{+} \mathrm{T}$ cell percentages upon stimulation of $\mathrm{CD} 4^{+} \mathrm{T}$ cells in the presence of $1,25(\mathrm{OH})_{2} \mathrm{D}[64,65,69]$.

The majority of the in vitro studies with human $\mathrm{CD}^{+} \mathrm{T}$ cells also showed that $1,25(\mathrm{OH})_{2} \mathrm{D}$ increased IL-10 cytokine secretion and mRNA expression by $\mathrm{CD} 4^{+} \mathrm{T}$ cells, as well as IL- $10^{+} \mathrm{CD}^{+} \mathrm{T}$ cell numbers in healthy individuals $[25,58,63,64,76]$. This also holds for $\mathrm{CD}^{+} T$ cells from Crohn's disease patients [63]. Most of these studies used monocultures of $\mathrm{CD}^{+} \mathrm{T}$ cells indicating that $1,25(\mathrm{OH})_{2} \mathrm{D}$ has a direct effect on the induction of IL-10 expressing $\mathrm{CD}^{+}{ }^{+} \mathrm{T}$ cells. Interestingly, the presence of monocytes may neutralize the positive effect of $1,25(\mathrm{OH})_{2} \mathrm{D}$ on the percentage of $\mathrm{IL}-10^{+} \mathrm{CD} 4^{+} \mathrm{T}$ cells [58]. Similar to IL-10, most human studies show an increase in FoxP3 mRNA expression and an increase of $\mathrm{FoxP}^{+} \mathrm{CD}^{+} \mathrm{T}$ cells when $\mathrm{CD} 4^{+} \mathrm{T}$ cells were cultured in the presence of $1,25(\mathrm{OH})_{2} \mathrm{D}[58,66,76,78]$. Again, the presence of monocytes may counteract this effect [58]. This is in contrast to studies mentioned before, in which activated monocyte derived $\mathrm{DC}$ cultured with $1,25(\mathrm{OH})_{2} \mathrm{D}$ gave an induction of Treg [51].

Several studies have evaluated the effects of $1,25(\mathrm{OH})_{2} \mathrm{D}$ on the regulatory function of Treg. In these studies, it is hard to discriminate between natural and inducible Treg. Fox $\mathrm{P3}^{+}$Treg induced by a $1,25(\mathrm{OH})_{2} \mathrm{D}$ analogue are able to suppress responder $\mathrm{T}$ cells [76]. In addition, $\mathrm{CD} 4^{+} \mathrm{CD} 25^{-} \mathrm{T}$ cells activated in the presence of $1,25(\mathrm{OH})_{2} \mathrm{D}$ are able to suppress $\mathrm{T}$ cell proliferation of freshly isolated $\mathrm{CD} 4^{+} \mathrm{CD} 25^{-} \mathrm{T}$ cells [58]. Finally, $\mathrm{CD}^{+}{ }^{+} \mathrm{CD} 25^{+} \mathrm{T}$ cells, considered to represent nTregs, reduced expression of IL-2 by responder cells in a $1,25(\mathrm{OH})_{2} \mathrm{D}$ dependent fashion [78].

$1,25(\mathrm{OH})_{2} \mathrm{D}$ treatment in mice shows contradicting results regarding FoxP3 ${ }^{+} \mathrm{CD}^{+} \mathrm{T}$ cells. One study showed a reduction in these Treg, while the other study did not observe a difference in Treg numbers between the placebo versus the $1,25(\mathrm{OH})_{2} \mathrm{D}$ treated group. These two studies were performed in the EAE model and, as described before, they analysed the $T$ cell compartment at a different moment in the disease course $[68,73]$.

In humans, a negative correlation was reported between serum 25(OH)D levels of RRMS patients and the number of FoxP3 ${ }^{+}$Treg [79]. We could not confirm this finding, however, we found a positive correlation between Treg function and 25(OH)D levels [74]. In contrast to the studies in RRMS patients, a positive correlation of serum 25(OH)D levels with FoxP3 $3^{+}$Treg as well as $\mathrm{IL}-10^{+} \mathrm{CD} 4^{+} \mathrm{T}$ cell percentages was found in Behçet patients during active disease [75]. A possible cause-effect relation could not be proven in a small vitamin $\mathrm{D}$ supplementation study in RRMS patients [80].

Thus, $1,25(\mathrm{OH})_{2} \mathrm{D}$ seems to have a positive effect on number and function of both $\operatorname{Tr} 1$ and FoxP3 ${ }^{+}$Tregs.

Cytotoxic $T$ cells $\left(C D 8^{+} T\right.$ cell)

Studies on the effect of $1,25(\mathrm{OH})_{2} \mathrm{D}$ on $\mathrm{CD}^{+} \mathrm{T}$ cells are limited. Possibly due to different methods of stimulation, $\mathrm{CD}^{+} \mathrm{T}$ cell proliferation may be inhibited, unaffected, or 
even enhanced in the presence of $1,25(\mathrm{OH})_{2} \mathrm{D}[23,59-61]$. The percentages of IL-2 producing $\mathrm{CD}^{+} \mathrm{T}$ cells, however, are consistently reduced upon addition of $1,25(\mathrm{OH})_{2} \mathrm{D}$ $[61,62]$. Also cytotoxicity, as measured in a chromium release assay, was hampered when cells were pretreated with $1,25(\mathrm{OH})_{2} \mathrm{D}[81]$.

Some studies investigated the expression of cytokines like IL-17, TNF- $\alpha$, and IL-6 by the $\mathrm{CD}^{+} \mathrm{T}$ cells. One study described that $1,25(\mathrm{OH})_{2} \mathrm{D}$ reduced the percentage of $\mathrm{TNF}-\alpha^{+} \mathrm{CD} 8^{+} \mathrm{T}$ cells upon stimulation with Epstein barr virus (EBV) peptide in both healthy controls and early MS patients [82]. Additionally, mRNA levels of IL-17 within $\mathrm{CD}^{+} \mathrm{T}$ cells were decreased in the presence of $1,25(\mathrm{OH})_{2} \mathrm{D}[76]$, while in another study $1,25(\mathrm{OH})_{2} \mathrm{D}$ was able to elevate the percentage of $\mathrm{IL}-6^{+} \mathrm{CD}^{+} T$ cells [62]. Like $\mathrm{CD4}^{+} \mathrm{T}$ cells, $\mathrm{CD} 8^{+} \mathrm{T}$ cells can be divided into type 1 (Tc1) IFN- $\gamma$ and type 2 (Tc2) IL-4 producing $\mathrm{CD}^{+} \mathrm{T}$ cells. Again, no consistent findings are obtained with respect to the effect of $1,25(\mathrm{OH})_{2} \mathrm{D}$ on human Tc1 and Tc2 cells $[61,62,76]$. 


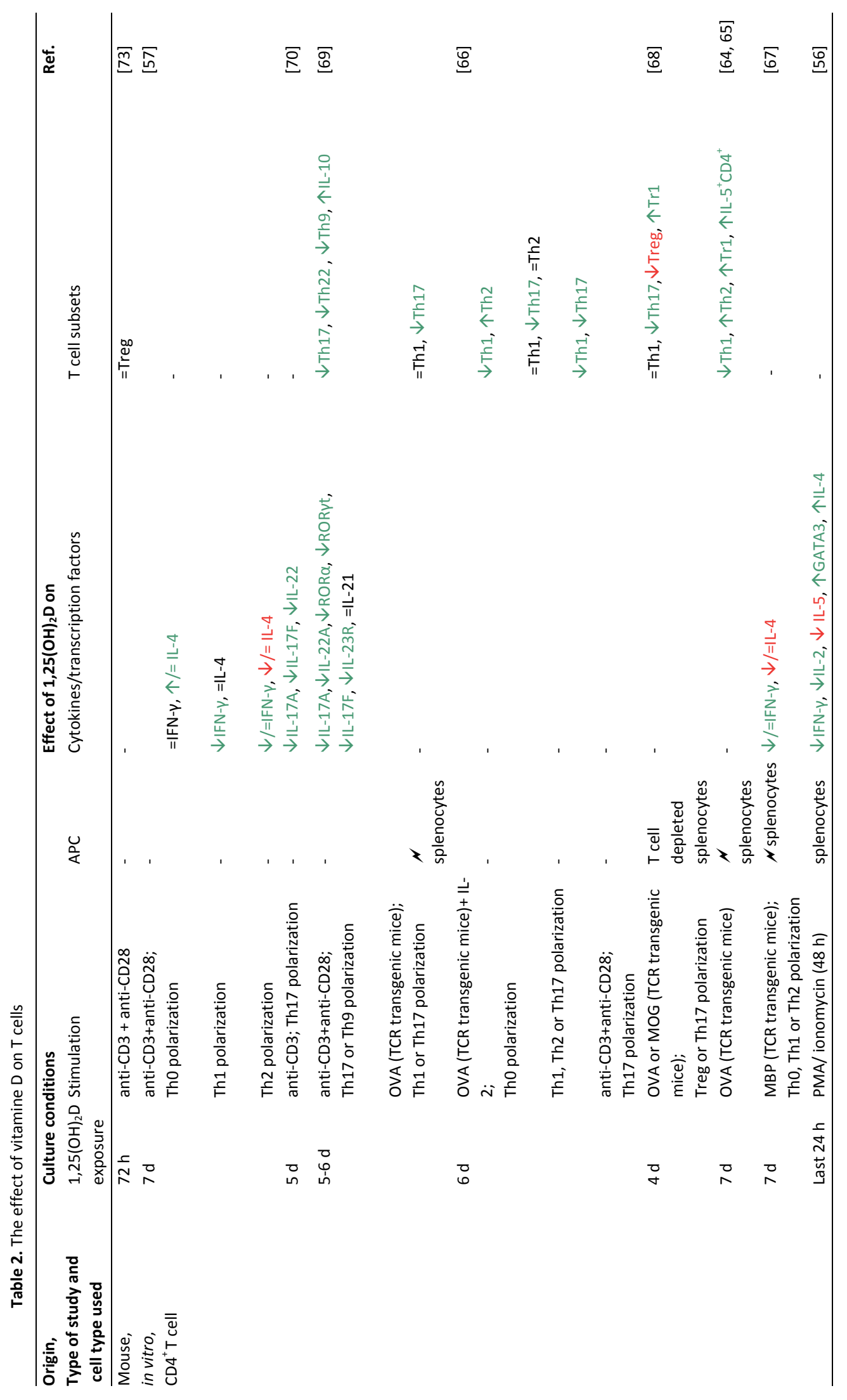




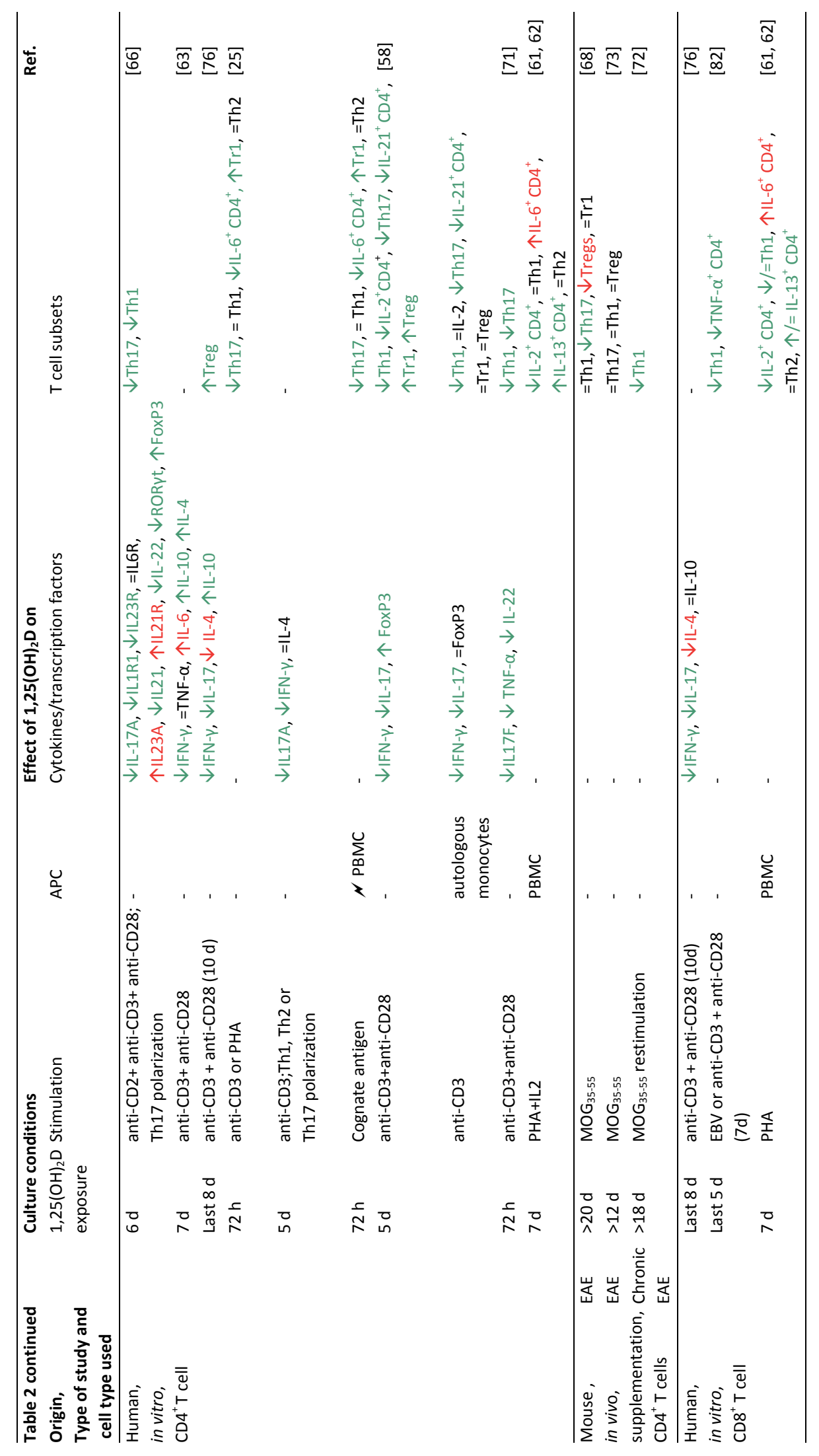


CHAPTER 2






\section{Effects of vitamin D on NK T cells}

CD1d-dependent natural killer-like T cells (NKT cells) are a potent early source of cytokines and therefore have a high immunoregulatory potential. NKT cell deficiency in mice leads to a predisposition to develop autoimmune diseases, and activation of these cells can change disease outcome, either positively or negatively depending on the timing of NKT cell activation. In addition, NKT cells have been reported to be numerically and functionally deficient in various autoimmune diseases in humans [83-85].

The role of vitamin D in NKT cell biology is not clear yet. Animal studies are scarce and studies on vitamin D and human NKT cells are not done so far. Furthermore, the VDR and the $1,25(\mathrm{OH})_{2} \mathrm{D}$ ligand seem to have a different role in regulating invariant NKT cell (iNKT) numbers and function. Data from VDR knock out (KO) mice show that iNKT cells have difficulties to develop in the absence of VDR, e.g. iNKT cell numbers, cell frequencies and proliferative capacity are affected. A-Galactosylceramide ( $\alpha$ GalCer) (NKT ligand) stimulated splenocytes of VDR KO mice produce less IFN- $\gamma$ and IL4. Interestingly, 1,25(OH) $2 \mathrm{D}(\mathrm{CyP} 27 \mathrm{~B} 1-\mathrm{KO})$ deficient mice have functionally normal iNKT cells, but a decreased frequency due to an increased apoptosis of iNKT cell precursors. $1,25(\mathrm{OH})_{2} \mathrm{D}$ supplementation did not increase the number of iNKT cells in WT mice, but it partially restored frequencies of iNKT cells in mice with vitamin D deficient diets. Furthermore, 1,25(OH $)_{2} \mathrm{D}$ supplementation in WT mice increased IFN- $\gamma$ and IL4 production by iNKT cells $[86,87]$. Data are summarized in Table $3 \mathrm{~A}$.

So up till now, $1,25(\mathrm{OH})_{2} \mathrm{D}$ seems to play a role in the development of mouse iNKT cells. Supplementation in case of vitamin D deficiency can increase number and function.

\section{Effects of vitamin D on NK cells}

NK cells have the ability to rapidly kill target cells and modulate adaptive immune responses through cytokine and chemokine secretion. NK cells have been implicated in autoimmune disease pathology. [88-92]

Although several studies show no effect of $1,25(\mathrm{OH})_{2} \mathrm{D}$ on NK effector function [93-96], others suggest a role of vitamin $D$ in the regulation of human NK cell function [97-104] (summarized in Table 3B). Patients with diseases affecting their vitamin D metabolism, like those with chronic renal failure (CRF) who undergo haemodialysis and patients with hypophosphatemic vitamin D-resistant rickets (VDRR), have an impaired immune response including defective NK cell activity $[98,102]$. In these patients NK cell activity can be improved or even normalized by administration of $1,25(\mathrm{OH})_{2} \mathrm{D}$ or the vitamin $\mathrm{D}$ analog $1 \alpha(\mathrm{OH}) \mathrm{D}$. Also in healthy elderly individuals NK cell cytolytic activity is associated with serum $25(\mathrm{OH}) \mathrm{D}$ levels $[100,101]$. These findings were confirmed in in vitro studies using a NK cell line or lymphokine activated killer cells in the absence 


\section{CHAPTER 2}

of monocytes. Addition of $1,25(\mathrm{OH})_{2} \mathrm{D}$ enhanced the activity of these cells in a dose dependent way without affecting cell proliferation. Besides, cellular granule content increased and the delay in secretion of granzyme A was shortened [97, 103]. However, in the presence of monocytes $1,25(\mathrm{OH})_{2} \mathrm{D}$ has opposite effects on NK cell cytotoxicity $[99,103,104]$. Interestingly, Deniz et al. showed that vitamin D in combination with dexamethasone upregulates IL-10 mRNA expression in purified and enriched NK cells of healthy donors. This suggests that vitamin D can stimulate function of NK cells with a regulatory phenotype [105].

So up till now, the effects of vitamin D on NK cell function in autoimmune disease are unclear. Vitamin $D$ does not seem to affect number or frequency of NK cells, but may alter their cytotoxic function. The differences in outcome with regard to NK cell cytotoxicity can partially be explained by the use of different target cells in the in vitro NK cytotoxicity assays. Furthermore immunomodulation of monocytes and activated lymphocytes by vitamin D can interfere with direct effects on NK cell cytotoxicity. Moreover, it is known that the cytotoxic activity of NK cells is dependent on extracellu$\operatorname{lar} \mathrm{Ca}^{2+}$. Therefore stimulation by $1,25(\mathrm{OH})_{2} \mathrm{D}$ or calcium ionophore can bias outcomes on cytotoxicity. 
VITAMIN D AND THE PERIPHERAL ADAPTIVE IMMUNE SYSTEM

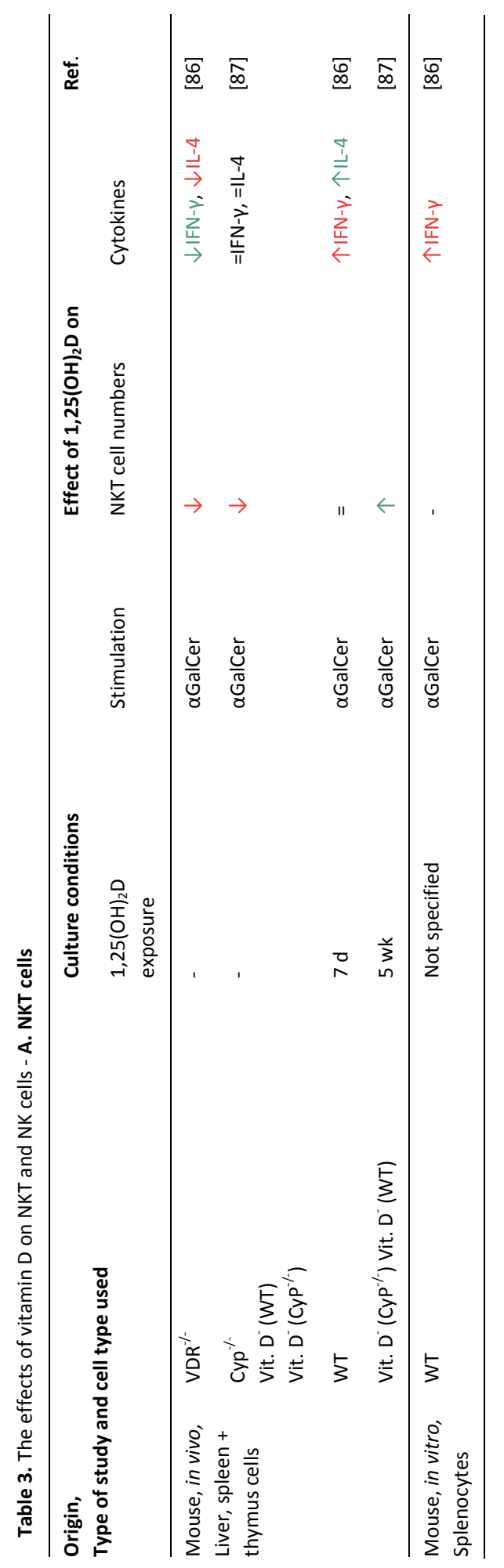




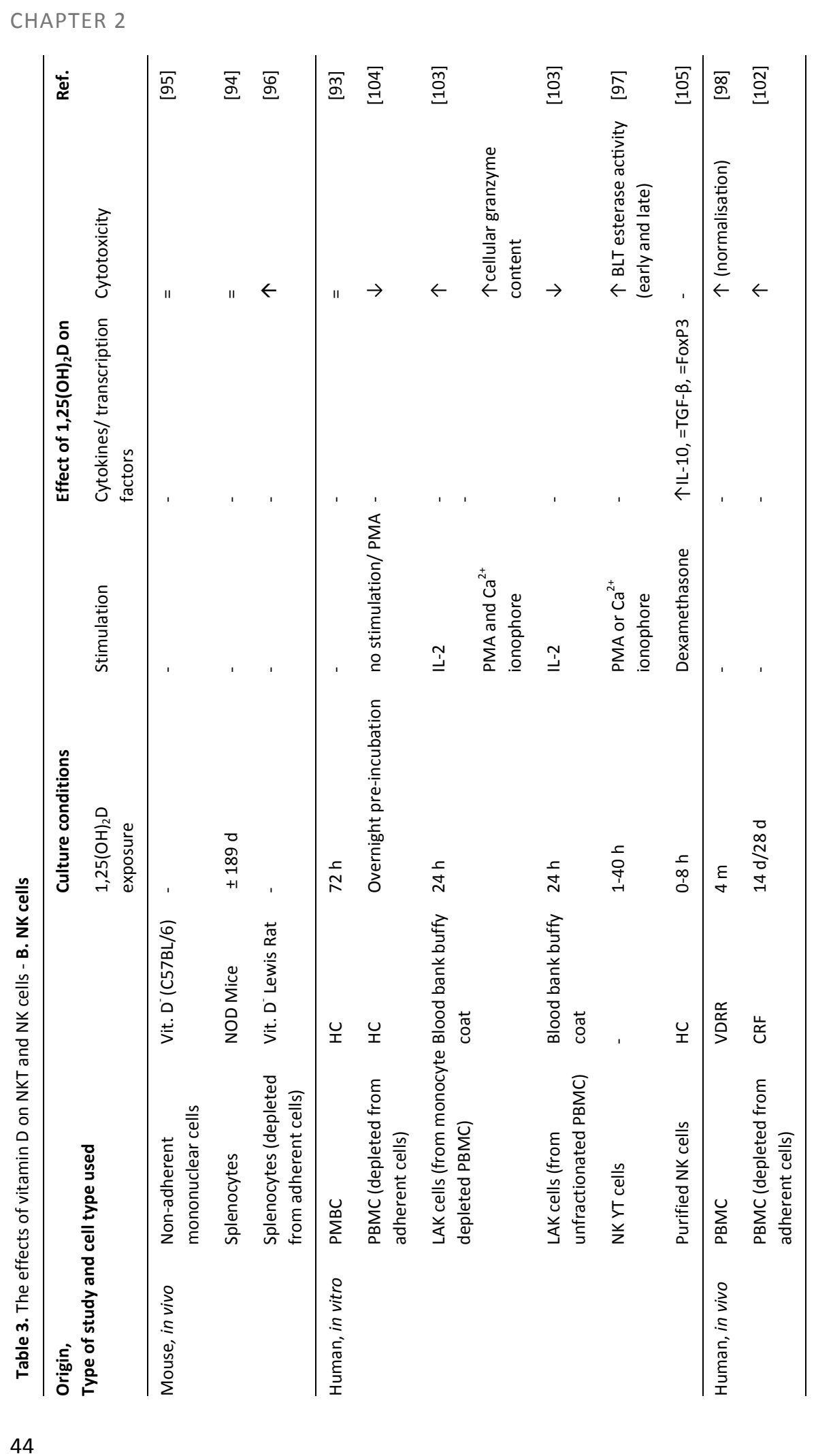


VITAMIN D AND THE PERIPHERAL ADAPTIVE IMMUNE SYSTEM

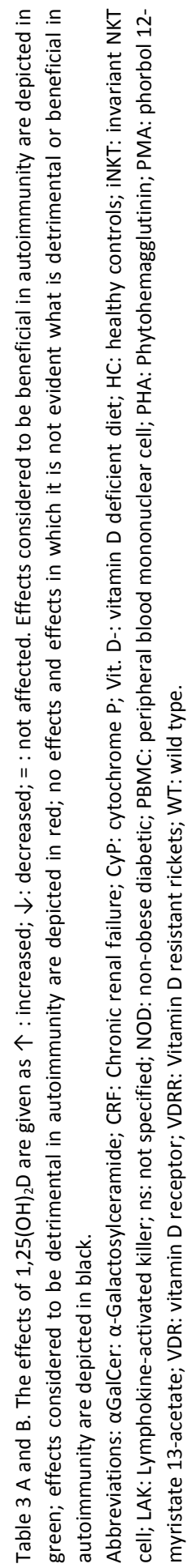




\section{CHAPTER 2}

\section{Effect of vitamin D on B cells}

Resting B cells have been shown to express negligible amounts of VDR. However, upon activation with various stimuli such as pokeweed mitogen (PWM) and $B$ cell receptor (BCR) crosslinking, VDR expression is up-regulated $[21,106]$. In addition, activated $B$ cells express CyP27B1, important in the hydroxylation and thus activation of 25(OH)D [30]. Consequently, $B$ cells have been shown to be a target of vitamin $D$ after activation stimuli. In vitro exposure of B cells or PBMC to $1,25(\mathrm{OH})_{2} \mathrm{D}$ after different specific $B$ cell stimuli significantly inhibited proliferation $[29,107,108]$. Particularly ongoing proliferation was inhibited by $1,25(\mathrm{OH})_{2} \mathrm{D}$ in $\mathrm{B}$ cell cultures [29]. In addition, apoptosis was increased in proliferating $B$ cells [29]. The differentiation into plasma cells $\left(\mathrm{CD} 38^{+} \mathrm{CD} 27^{+}\right)$and post-switch memory $\mathrm{B}$ cells $\left(\mathrm{CD} 19^{+} \operatorname{lgG}{ }^{+}\right)$was inhibited in the presence of $1,25(\mathrm{OH})_{2} \mathrm{D}$ after activation of sorted naive $B$ cells $\left(\mathrm{CD}^{\prime} 9^{+} \mid \mathrm{gG} \mathrm{G}^{-} \mathrm{CD} 27^{-}\right)$with $\mathrm{B}$ cell receptor (BCR) cross-linking and /or anti-CD40 and IL-21 [29]. Subsequently, synthesis of IgM, IgG and IgA on various stimuli was shown to be inhibited in vitro [29, 106-111]. Data on the effects of $1,25(\mathrm{OH})_{2} \mathrm{D}$ on IgE secretion are conflicting. Although in vitro experiments showed a reduced IgE secretion [110], in vivo animal experiments demonstrated an increased serum IgE after $1,25(\mathrm{OH})_{2} \mathrm{D}$ treatment [112]. In addition, in a large British epidemiological study, extreme low or high values of 25(OH)D correlated in a U-shape form with high IgE concentrations. A high 25(OH)D level (>135 nmol/L) was also associated with high specific IgE concentrations [113]. It is hypothesized that $\mathrm{U}$-shape correlations with serum $25(\mathrm{OH}) \mathrm{D}$ levels are secondary to the enzymatic metabolism of $25(\mathrm{OH}) \mathrm{D}$, and not to the serum 25(OH)D level per se [114]. An interesting new area in $B$ cell biology is the IL-10 producing regulatory $B$ cells (Bregs). B cells stimulated via the $B C R$, anti-CD40 and IL-4 were shown to produce IL-10. Addition of $1,25(\mathrm{OH})_{2} \mathrm{D}$ to these stimuli significantly increased the secretion of IL-10 [30]. However, in an exploratory cross-sectional study in RRMS patients and in healthy controls, we could not demonstrate a correlation between Breg numbers and vitamin D status [Knippenberg et al., in preparation]. However, this does not rule out an effect of vitamin $D$ on Bregs, since it might be the function of these cells instead of the proportion that is affected by vitamin D. However, the observed effects of $1,25(\mathrm{OH})_{2} \mathrm{D}$ in vitro (summarized in Table 4) are not yet confirmed in vivo. Especially the role of $1,25(\mathrm{OH})_{2} \mathrm{D}$ in the induction of IL-10 producing regulatory $B$ cells in vivo adds an exciting new area to the field of vitamin $D$ and $B$ cells. The field of regulatory $B$ cell biology has enormously expanded recently, but consequently lacks standardization of methods. Finally, the non-linear correlation between IgE production and vitamin D status, indicating a possible higher risk of allergic responses with increasing vitamin $D$ levels, might have clinical implications in ongoing and upcoming vitamin $D$ trials. 


\section{Discussion}

We reviewed the effects of vitamin $D$ on immune cells with a focus on the peripheral adaptive immune system. A schematic overview of the described major effects of vitamin $D$ is given in Figure 1 . We speculate that vitamin $D$ is not an immunosuppressive agent, but rather an immune regulatory agent. The beneficial effects of vitamin $D$ in autoimmunity include the induction of tolerogenic DC, which includes the downregulation of co-stimulatory molecules, a decreased IL-12 secretion and increased IL-10 secretion in APC, and the ability of these APC to induce Treg rather than effector T cells. Vitamin $D$ can also directly promote development and function of Treg in vitro. Furthermore, effector T cells are both directly and indirectly affected, resulting in a shift in the Th1 / Th2 balance towards Th2 and in a reduction of the Th17 response. The development of NKT cells seems to be affected by vitamin D, however, data are limited. Knowledge on the functions of $B$ cells have expanded in the last few years from antibody production, to antigen presentation and cytokine production. Although the latter functions of $B$ cells are affected by vitamin $D$ in vitro, in vivo effects are relatively unexplored. The effect of vitamin $D$ on Breg induction and function is another interesting topic of future research, since $1,25(\mathrm{OH})_{2} \mathrm{D}$ inhibits the induction of EAE by an IL-10 producing RAG1 dependent cell $[67,115]$. Besides Treg, also Breg fulfil these criteria. Altogether, we hypothesize that vitamin $D$ is not a suppressive agent, but is important in maintaining or restoring homeostasis in the immune system, and hereby is beneficial in autoimmunity.

It should be noted that a major part of the information on the immune modulating potential of vitamin $D$ comes from in vitro experiments, while the effects in vivo are the end result of a plethora of effects and a complex interplay between multiple vitamin $D$ sensitive cells. So far, vitamin $D$ supplementation trials in healthy controls and autoimmunity are scarce $[80,116,117,118,124]$. High dose vitamin D supplementation in 15 RRMS patients did not affect Th1, Th2, Th17 or FoxP3 ${ }^{+}$Treg cell percentages, but resulted in an increased percentage of $\mathrm{IL}-10^{+} \mathrm{CD} 4^{+} \mathrm{T}$ cells and a shift of the Th1 / Th2 ratio towards Th2 [80]. In contrast, treatment of 7 undifferentiated connective tissue disease (UCTD) patients with a vitamin $D$ analogue (alfacalcidol) caused reduced Th1 and Th17 cell percentages and increased $\mathrm{CD} 4^{+} \mathrm{IL}-4^{+} \mathrm{T}$ cell percentages [118]. 


\section{CHAPTER 2}

Table 4. The effects of vitamin D on B cells

\begin{tabular}{|c|c|c|c|c|c|c|}
\hline Origin, & Culture condi & itions & Effect of 1,25( & $\mathrm{OH})_{2} \mathrm{D}$ on & \multirow[b]{2}{*}{$\begin{array}{l}\text { Phenotypic } \\
\text { markers / } \\
\text { Subsets }\end{array}$} & \multirow[t]{2}{*}{ Ref. } \\
\hline $\begin{array}{l}\text { study } \\
\text { and cell type } \\
\text { used }\end{array}$ & $\begin{array}{l}1,25(\mathrm{OH})_{2} \mathrm{D} \\
\text { exposure }\end{array}$ & Stimulation & Proliferation & Immunoglobulins & & \\
\hline $\begin{array}{l}\text { Human, in } \\
\text { vitro, PBMC }\end{array}$ & $2-11 d$ & \multicolumn{2}{|c|}{$\begin{array}{l}\text { PWM, PHA, DO, Inhibited } \\
\text { or SAC }\end{array}$} & \multicolumn{2}{|l|}{$\downarrow \lg M, \downarrow \lg G, \downarrow \lg A-$} & $\begin{array}{c}{[108,109,} \\
111]\end{array}$ \\
\hline $\begin{array}{l}\text { Mouse, ex } \\
\text { vivo, PBMC }\end{array}$ & sc.i. & Ova & - & $\begin{array}{l}\text { 个g } E, \downarrow \lg G, \\
\downarrow \lg G 1,=\lg G 2\end{array}$ & - & [112] \\
\hline $\begin{array}{l}\text { Human, ex } \\
\text { vivo, PBMC }\end{array}$ & $\begin{array}{l}\text { Oral } \\
\text { treatment for } \\
7 \mathrm{~d}\end{array}$ & 24 hours SPA & Unaffected & $=\lg M,=\lg G$ & - & [40] \\
\hline \multirow{5}{*}{$\begin{array}{l}\text { Human, in } \\
\text { vitro, B cells }\end{array}$} & $14 \mathrm{~d}$ & EBV & - & $\downarrow \lg M, \downarrow \lg G$ & - & {$[106]$} \\
\hline & $6 \mathrm{~d}$ & $\begin{array}{l}\text { with PWM or } \\
\text { SAC }(6 d)\end{array}$ & Inhibited & $\downarrow \lg G$ & - & [107] \\
\hline & $10 \mathrm{~d}$ & $\begin{array}{l}\text { Anti-CD40, IL-4 } \\
10 \mathrm{~d}\end{array}$ & Unaffected & $\begin{array}{l}=/ \downarrow \lg M,=\lg G, \\
=\lg A, \downarrow \lg E\end{array}$ & $\downarrow \mathrm{CD} 23, \uparrow I \mathrm{~L}-6$ & [110] \\
\hline & $4-7 d$ & $\begin{array}{l}\text { Anti-CD40, anti- } \\
\text { IgM, IL-21, IL-4 }\end{array}$ & $\begin{array}{l}\text { Initial } \\
\text { proliferation } \\
\text { unaffected, } \\
\text { ongoing } \\
\text { proliferation } \\
\text { inhibited }\end{array}$ & $\downarrow \lg M, \downarrow \lg G$ & $\begin{array}{l}=\mathrm{CD} 21,=\mathrm{CD} 23, \\
=\mathrm{CD} 40,=\mathrm{CD} 86, \\
=\mathrm{MHC}-\mathrm{II}, \\
\downarrow \text { Plasma cell, } \\
=\text { memory cell, } \\
\downarrow \mathrm{mlgG} \uparrow \mathrm{mlgM}\end{array}$ & [29] \\
\hline & $48 \mathrm{~h}$ & $\begin{array}{l}\text { BCR cross- } \\
\text { linking, anti- } \\
\text { CD40, IL-4 for } \\
48 \mathrm{~h}\end{array}$ & Unaffected & $=\lg G$ & 个CD38, 个IL-10 & [30] \\
\hline
\end{tabular}

Table 4 . The effects of $1,25(\mathrm{OH})_{2} \mathrm{D}$ are given as $\uparrow$ : increased; $\downarrow$ : decreased; = : not affected. Effects considered to be beneficial in autoimmunity are depicted in green; effects considered to be detrimental in autoimmunity are depicted in red; no effects and effects in which it is not evident what is detrimental or beneficial in autoimmunity are depicted in black.

Naive B cell $\mathrm{CD} 19^{+} \mathrm{CD} 27^{-}$; memory B cell $\mathrm{CD} 19^{+} \mathrm{CD} 27^{+}$; unswitched memory B cell $\mathrm{CD}_{19^{+}} \mathrm{IgD}^{+} \mathrm{CD} 27^{+}$; switched memory $\mathrm{B}$ cell $\mathrm{CD}_{19} 9^{+} \mathrm{IgD}^{-} \mathrm{CD} 27^{+}$; Plasma cell $\mathrm{CD} 19^{+} \mathrm{CD} 27^{+} \mathrm{CD} 38^{+}$.

Abbreviations: BAFF: B cell activating factor; BCR: B cell receptor; DO: dermatophyton O; EBV: Epstein Barr virus; Ig: Immunoglobulin; mlg: membrane Immunoglobulin; OVA: ovalbumin; PBMC: peripheral blood mononuclear cell; PHA: Phytohemagglutinin; PWM: Pokeweed Mitogen; SAC: Staphylococcus aureus Cowan I, sc.i.: subcutaneous injection; SPA: Staphylococcus aureus protein A

In 50 healthy controls, vitamin D supplementation increased the percentages of FoxP ${ }^{+}$ Tregs [116]. Moreover, in 15 supplemented RRMS patients with a low baseline serum 
25(OH)D level, a trend towards an improved Treg function was seen [80]. In addition, in the supplemented RRMS patients, no effect was seen on plasma cell and post-switch memory B cell differentiation and on total Ig antibody production [124]. However, alternative outcome measures as cytokine production and specific Ig production remain unexplored.

Although we chose not to discuss research concerning the effects of vitamin D on the migratory potential of immune cells, these effects may have important functional implications in vivo and therefore should not be neglected in upcoming research. Besides immune regulation and the well known functions of vitamin $D$ on mineral and bone regulation, associations with cognitive $[119,120]$ and depressive disorders [121] have been made, and therefore vitamin $\mathrm{D}$ might also influence the immune system via cross-talk with the neuro-endocrine system.

Importantly, cells of the immune system are not only targets of vitamin D metabolites, but they are also able to activate or inactivate vitamin $D$ metabolites, arguing for a local role of vitamin $D$ within the immune system [122]. A recent study showed a differential expression of these vitamin $\mathrm{D}$ related genes in $\mathrm{CD} 4^{+} \mathrm{T}$ cells and in PBMC, suggesting these cells have distinct roles in local vitamin D metabolism [123].

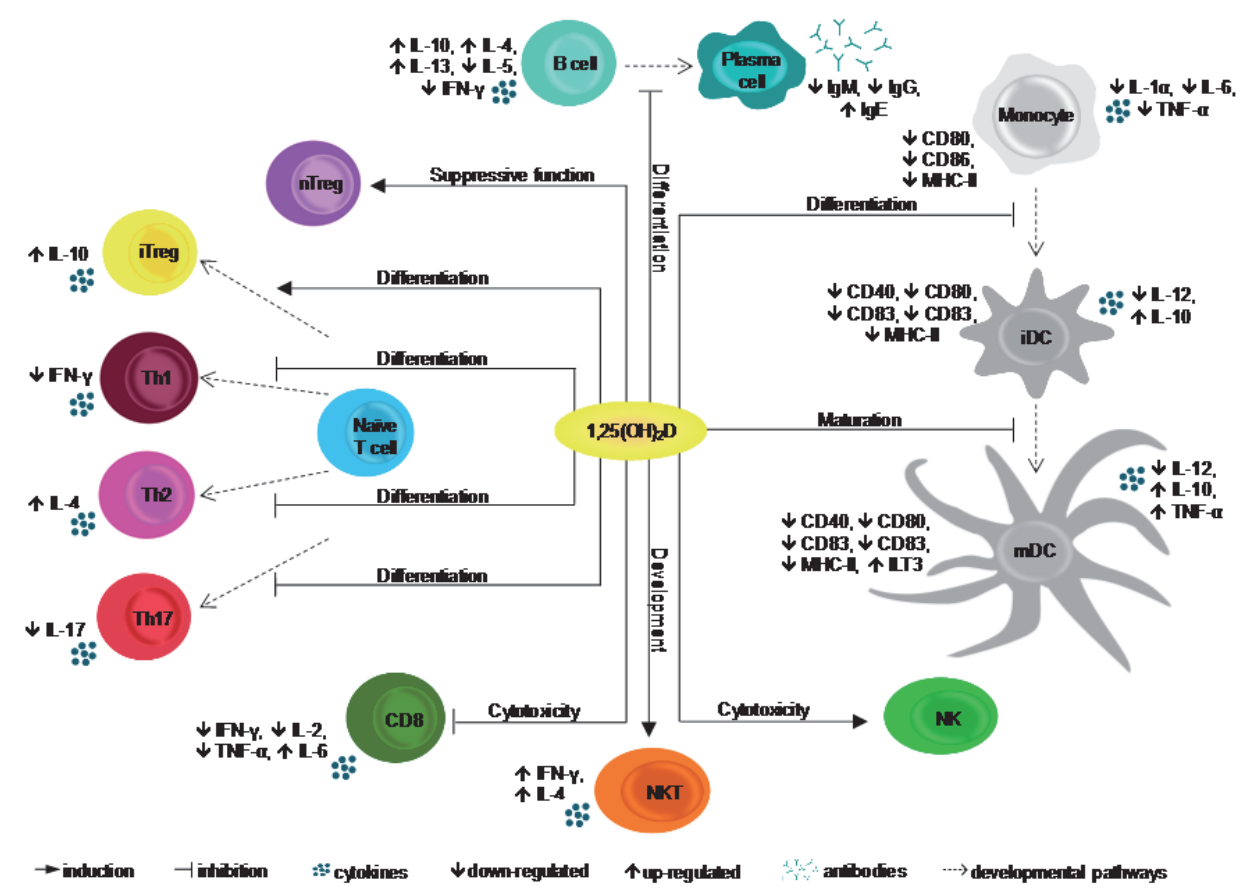

Figure 1. An overview of the overall effects of $1,25(\mathrm{OH})_{2} \mathrm{D}$ on monocytes, dendritic, $T, N K T$, NK and B cells. 


\section{CHAPTER 2}

In conclusion, vitamin D supplementation could be an appealing strategy to use as an immune regulating agent to treat or subside autoimmune diseases. Patients with renal insufficiency or with granulomatous disease, however, are at risk for serious side effects and should be excluded from vitamin D supplementation. Upcoming vitamin D supplementation trials will provide more clarity in the in vivo effects and the opportunities and possible limitations of vitamin $D$ as an immune regulating agent. 


\section{References}

1. Abbas S, Linseisen J, Slanger T, Kropp S, Mutschelknauss EJ, Flesch-Janys D, et al. Serum 25hydroxyvitamin $\mathrm{D}$ and risk of post-menopausal breast cancer--results of a large case-control study. Carcinogenesis. 2008;29:93-9.

2. Yin L, Grandi N, Raum E, Haug U, Arndt V, Brenner H. Meta-analysis: longitudinal studies of serum vitamin D and colorectal cancer risk. Aliment Pharmacol Ther. 2009;30:113-25.

3. Yin L, Raum E, Haug U, Arndt V, Brenner H. Meta-analysis of longitudinal studies: Serum vitamin D and prostate cancer risk. Cancer Epidemiol. 2009;33:435-45.

4. Giovannucci E, Liu Y, Hollis BW, Rimm EB. 25-hydroxyvitamin D and risk of myocardial infarction in men: a prospective study. Arch Intern Med. 2008;168:1174-80.

5. Pilz S, Tomaschitz A, Ritz E, Pieber TR. Vitamin D status and arterial hypertension: a systematic review. Nat Rev Cardiol. 2009;6:621-30.

6. Ascherio A, Munger KL, Simon KC. Vitamin D and multiple sclerosis. Lancet Neurol. 2010;9:599-612.

7. Hypponen E, Laara E, Reunanen A, Jarvelin MR, Virtanen SM. Intake of vitamin D and risk of type 1 diabetes: a birth-cohort study. Lancet. 2001;358:1500-3.

8. Kamen DL, Cooper GS, Bouali H, Shaftman SR, Hollis BW, Gilkeson GS. Vitamin D deficiency in systemic lupus erythematosus. Autoimmun Rev. 2006;5:114-7.

9. Gatenby PA, Lucas RM, Engelsen O, Ponsonby AL, Clements M. Antineutrophil cytoplasmic antibodyassociated vasculitides: could geographic patterns be explained by ambient ultraviolet radiation? Arthritis Rheum. 2009;61:1417-24.

10. Cutolo M, Otsa K, Paolino S, Yprus M, Veldi T, Seriolo B. Vitamin D involvement in rheumatoid arthritis and systemic lupus erythaematosus. Ann Rheum Dis. 2009;68:446-7.

11. Pelajo CF, Lopez-Benitez JM, Miller LC. Vitamin D and autoimmune rheumatologic disorders. Autoimmun Rev. 2010;9:507-10.

12. Hollis BW, Wagner CL, Drezner MK, Binkley NC. Circulating vitamin D3 and 25-hydroxyvitamin D in humans: An important tool to define adequate nutritional vitamin D status. J Steroid Biochem Mol Biol. 2007;103:631-4.

13. Institute of Medicine (U.S.). Standing Committee on the Scientific Evaluation of Dietary Reference Intakes. Dietary reference intakes : for calcium, phosphorus, magnesium, vitamin D, and fluoride. Washington, D.C.: National Academy Press, 1997.

14. Smith JE, Goodman DS. The turnover and transport of vitamin D and of a polar metabolite with the properties of 25-hydroxycholecalciferol in human plasma. J Clin Invest. 1971;50:2159-67.

15. Omdahl JL, Morris HA, May BK. Hydroxylase enzymes of the vitamin D pathway: expression, function, and regulation. Annu Rev Nutr. 2002;22:139-66.

16. Norman AW. Minireview: vitamin D receptor: new assignments for an already busy receptor. Endocrinology. 2006;147:5542-8.

17. Norman PE, Powell JT. Vitamin D, shedding light on the development of disease in peripheral arteries. Arterioscler Thromb Vasc Biol. 2005;25:39-46.

18. Smolders J, Peelen E, Thewissen M, Menheere P, Tervaert JW, Hupperts R, et al. The relevance of vitamin $\mathrm{D}$ receptor gene polymorphisms for vitamin $\mathrm{D}$ research in multiple sclerosis. Autoimmun Rev. 2009;8:621-6.

19. Muller K, Haahr PM, Diamant M, Rieneck K, Kharazmi A, Bendtzen K. 1,25-Dihydroxyvitamin D3 inhibits cytokine production by human blood monocytes at the post-transcriptional level. Cytokine. 1992;4:506-12.

20. Penna G, Amuchastegui S, Giarratana N, Daniel KC, Vulcano M, Sozzani S, et al. 1,25-Dihydroxyvitamin D3 selectively modulates tolerogenic properties in myeloid but not plasmacytoid dendritic cells. J Immunol. 2007;178:145-53. 


\section{CHAPTER 2}

21. Provvedini DM, Tsoukas CD, Deftos LJ, Manolagas SC. 1,25-dihydroxyvitamin D3 receptors in human leukocytes. Science. 1983;221:1181-3.

22. Rigby WF, Waugh M, Graziano RF. Regulation of human monocyte HLA-DR and CD4 antigen expression, and antigen presentation by 1,25-dihydroxyvitamin D3. Blood. 1990;76:189-97.

23. Veldman CM, Cantorna MT, DeLuca HF. Expression of 1,25-dihydroxyvitamin $\mathrm{D}(3)$ receptor in the immune system. Arch Biochem Biophys. 2000;374:334-8.

24. Sigmundsdottir H, Pan J, Debes GF, Alt C, Habtezion A, Soler D, et al. DCs metabolize sunlight-induced vitamin D3 to 'program' T cell attraction to the epidermal chemokine CCL27. Nat Immunol. 2007;8:28593.

25. Correale J, Ysrraelit MC, Gaitan MI. Immunomodulatory effects of Vitamin D in multiple sclerosis. Brain. 2009;132:1146-60.

26. Fritsche J, Mondal K, Ehrnsperger A, Andreesen R, Kreutz M. Regulation of 25-hydroxyvitamin D3-1 alpha-hydroxylase and production of 1 alpha,25-dihydroxyvitamin D3 by human dendritic cells. Blood. 2003;102:3314-6.

27. Gottfried E, Rehli M, Hahn J, Holler E, Andreesen R, Kreutz M. Monocyte-derived cells express CYP27A1 and convert vitamin D3 into its active metabolite. Biochem Biophys Res Commun. 2006;349:209-13.

28. Szeles L, Keresztes G, Torocsik D, Balajthy Z, Krenacs L, Poliska S, et al. 1,25-dihydroxyvitamin D3 is an autonomous regulator of the transcriptional changes leading to a tolerogenic dendritic cell phenotype. J Immunol. 2009;182:2074-83.

29. Chen S, Sims GP, Chen XX, Gu YY, Lipsky PE. Modulatory effects of 1,25-dihydroxyvitamin D3 on human B cell differentiation. J Immunol. 2007;179:1634-47.

30. Heine G, Niesner U, Chang HD, Steinmeyer A, Zugel U, Zuberbier T, et al. 1,25-dihydroxyvitamin $D(3)$ promotes IL-10 production in human B cells. Eur J Immunol. 2008;38:2210-8.

31. Marcenaro E, Ferranti B, Moretta A. NK-DC interaction: on the usefulness of auto-aggression. Autoimmun Rev. 2005;4:520-5.

32. Rigby WF, Waugh MG. Decreased accessory cell function and costimulatory activity by 1,25dihydroxyvitamin D3-treated monocytes. Arthritis Rheum. 1992;35:110-9.

33. Steinman RM, Banchereau J. Taking dendritic cells into medicine. Nature. 2007;449:419-26.

34. Steinman RM, Hawiger D, Nussenzweig MC. Tolerogenic dendritic cells. Annu Rev Immunol. 2003;21:685-711.

35. Adorini L, Penna G. Induction of tolerogenic dendritic cells by vitamin D receptor agonists. Handb Exp Pharmacol. 2009:251-73.

36. Almerighi C, Sinistro A, Cavazza A, Ciaprini C, Rocchi G, Bergamini A. 1Alpha,25-dihydroxyvitamin D3 inhibits CD40L-induced pro-inflammatory and immunomodulatory activity in human monocytes. Cytokine. 2009;45:190-7.

37. Kuo YT, Kuo CH, Lam KP, Chu YT, Wang WL, Huang CH, et al. Effects of vitamin D3 on expression of tumor necrosis factor-alpha and chemokines by monocytes. J Food Sci. 2010;75:H200-4.

38. D'Ambrosio D, Cippitelli M, Cocciolo MG, Mazzeo D, Di Lucia P, Lang R, et al. Inhibition of IL-12 production by 1,25-dihydroxyvitamin D3. Involvement of NF-kappaB downregulation in transcriptional repression of the p40 gene. J Clin Invest. 1998;101:252-62.

39. Matilainen JM, Husso T, Toropainen S, Seuter S, Turunen MP, Gynther P, et al. Primary effect of 1alpha, 25(OH)D on IL-10 expression in monocytes is short-term down-regulation. Biochim Biophys Acta. 2010;1803:1276-86.

40. Muller K, Diamant M, Bendtzen K. Inhibition of production and function of interleukin- 6 by 1,25 dihydroxyvitamin D3. Immunol Lett. 1991;28:115-20.

41. Bettelli E, Carrier Y, Gao W, Korn T, Strom TB, Oukka M, et al. Reciprocal developmental pathways for the generation of pathogenic effector TH17 and regulatory T cells. Nature. 2006;441:235-8.

42. Romani N, Gruner S, Brang D, Kampgen E, Lenz A, Trockenbacher B, et al. Proliferating dendritic cell progenitors in human blood. J Exp Med. 1994;180:83-93. 
43. Chapuis F, Rosenzwajg M, Yagello M, Ekman M, Biberfeld P, Gluckman JC. Differentiation of human dendritic cells from monocytes in vitro. Eur J Immunol. 1997;27:431-41.

44. Jonuleit H, Kuhn U, Muller G, Steinbrink K, Paragnik L, Schmitt E, et al. Pro-inflammatory cytokines and prostaglandins induce maturation of potent immunostimulatory dendritic cells under fetal calf serumfree conditions. Eur J Immunol. 1997;27:3135-42.

45. Penna G, Adorini L. 1 Alpha,25-dihydroxyvitamin D3 inhibits differentiation, maturation, activation, and survival of dendritic cells leading to impaired alloreactive T cell activation. J Immunol. 2000;164:240511.

46. Piemonti L, Monti P, Sironi M, Fraticelli P, Leone BE, Dal Cin E, et al. Vitamin D3 affects differentiation, maturation, and function of human monocyte-derived dendritic cells. J Immunol. 2000;164:4443-51.

47. van Halteren AG, van Etten E, de Jong EC, Bouillon R, Roep BO, Mathieu C. Redirection of human autoreactive T-cells Upon interaction with dendritic cells modulated by TX527, an analog of 1,25 dihydroxyvitamin D(3). Diabetes. 2002;51:2119-25.

48. Griffin MD, Lutz W, Phan VA, Bachman LA, McKean DJ, Kumar R. Dendritic cell modulation by 1alpha,25 dihydroxyvitamin D3 and its analogs: a vitamin D receptor-dependent pathway that promotes a persistent state of immaturity in vitro and in vivo. Proc Natl Acad Sci U S A. 2001;98:6800-5.

49. Griffin MD, Lutz WH, Phan VA, Bachman LA, McKean DJ, Kumar R. Potent inhibition of dendritic cell differentiation and maturation by vitamin D analogs. Biochem Biophys Res Commun. 2000;270:701-8.

50. Kleijwegt FS, Laban S, Duinkerken G, Joosten AM, Zaldumbide A, Nikolic T, et al. Critical role for TNF in the induction of human antigen-specific regulatory $T$ cells by tolerogenic dendritic cells. J Immunol. 2010;185:1412-8.

51. Penna G, Roncari A, Amuchastegui S, Daniel KC, Berti E, Colonna M, et al. Expression of the inhibitory receptor ILT3 on dendritic cells is dispensable for induction of CD4+Foxp3+ regulatory T cells by 1,25 dihydroxyvitamin D3. Blood. 2005;106:3490-7.

52. Unger WW, Laban S, Kleijwegt FS, van der Slik AR, Roep BO. Induction of Treg by monocyte-derived DC modulated by vitamin D3 or dexamethasone: differential role for PD-L1. Eur J Immunol. 2009;39:314759.

53. Shortman K, Liu YJ. Mouse and human dendritic cell subtypes. Nat Rev Immunol. 2002;2:151-61.

54. von Essen MR, Kongsbak M, Schjerling P, Olgaard K, Odum N, Geisler C. Vitamin D controls T cell antigen receptor signaling and activation of human T cells. Nat Immunol. 2010;11:344-9.

55. Lacey DL, Axelrod J, Chappel JC, Kahn AJ, Teitelbaum SL. Vitamin D affects proliferation of a murine T helper cell clone. J Immunol. 1987;138:1680-6.

56. Mahon BD, Gordon SA, Cruz J, Cosman F, Cantorna MT. Cytokine profile in patients with multiple sclerosis following vitamin D supplementation. J Neuroimmunol. 2003;134:128-32.

57. Staeva-Vieira TP, Freedman LP. 1,25-dihydroxyvitamin D3 inhibits IFN-gamma and IL-4 levels during in vitro polarization of primary murine CD4+ T cells. J Immunol. 2002;168:1181-9.

58. Jeffery LE, Burke F, Mura M, Zheng Y, Qureshi OS, Hewison M, et al. 1,25-Dihydroxyvitamin D3 and IL-2 combine to inhibit $\mathrm{T}$ cell production of inflammatory cytokines and promote development of regulatory T cells expressing CTLA-4 and FoxP3. J Immunol. 2009;183:5458-67.

59. Lemire JM, Adams JS, Kermani-Arab V, Bakke AC, Sakai R, Jordan SC. 1,25-Dihydroxyvitamin D3 suppresses human T helper/inducer lymphocyte activity in vitro. J Immunol. 1985;134:3032-5.

60. Vanham G, Ceuppens JL, Bouillon R. T lymphocytes and their CD4 subset are direct targets for the inhibitory effect of calcitriol. Cell Immunol. 1989;124:320-33.

61. Thien R, Baier K, Pietschmann P, Peterlik M, Willheim M. Interactions of 1 alpha,25-dihydroxyvitamin D3 with IL-12 and IL-4 on cytokine expression of human T lymphocytes. J Allergy Clin Immunol. 2005;116:683-9.

62. Willheim M, Thien R, Schrattbauer K, Bajna E, Holub M, Gruber R, et al. Regulatory effects of 1alpha,25-dihydroxyvitamin D3 on the cytokine production of human peripheral blood lymphocytes. J Clin Endocrinol Metab. 1999;84:3739-44. 


\section{CHAPTER 2}

63. Bartels LE, Jorgensen SP, Agnholt J, Kelsen J, Hvas CL, Dahlerup JF. 1,25-dihydroxyvitamin D3 and dexamethasone increase interleukin-10 production in CD4+ T cells from patients with Crohn's disease. Int Immunopharmacol. 2007;7:1755-64.

64. Barrat FJ, Cua DJ, Boonstra A, Richards DF, Crain C, Savelkoul HF, et al. In vitro generation of interleukin 10-producing regulatory $\mathrm{CD} 4(+) \mathrm{T}$ cells is induced by immunosuppressive drugs and inhibited by $\mathrm{T}$ helper type 1 (Th1)- and Th2-inducing cytokines. J Exp Med. 2002;195:603-16.

65. Boonstra A, Barrat FJ, Crain C, Heath VL, Savelkoul HF, O'Garra A. 1alpha,25-Dihydroxyvitamin d3 has a direct effect on naive CD4(+) T cells to enhance the development of Th2 cells. J Immunol. 2001;167:4974-80.

66. Ikeda U, Wakita D, Ohkuri T, Chamoto K, Kitamura H, Iwakura Y, et al. 1alpha,25-Dihydroxyvitamin D3 and all-trans retinoic acid synergistically inhibit the differentiation and expansion of Th17 cells. Immunol Lett. 2010;134:7-16.

67. Nashold FE, Hoag KA, Goverman J, Hayes CE. Rag-1-dependent cells are necessary for 1,25dihydroxyvitamin $\mathrm{D}(3)$ prevention of experimental autoimmune encephalomyelitis. J Neuroimmunol. 2001;119:16-29.

68. Chang JH, Cha HR, Lee DS, Seo KY, Kweon MN. 1,25-Dihydroxyvitamin D3 inhibits the differentiation and migration of $T(H) 17$ cells to protect against experimental autoimmune encephalomyelitis. PLoS One. 2010;5:e12925.

69. Palmer MT, Lee YK, Maynard CL, Oliver JR, Bikle DD, Jetten AM, et al. Lineage-specific effects of 1,25dihydroxyvitamin D(3) on the development of effector CD4 T cells. J Biol Chem. 2011;286:997-1004.

70. Chang SH, Chung Y, Dong C. Vitamin D suppresses Th17 cytokine production by inducing C/EBP homologous protein (CHOP) expression. J Biol Chem. 2010;285:38751-5.

71. Colin EM, Asmawidjaja PS, van Hamburg JP, Mus AM, van Driel M, Hazes JM, et al. 1,25 dihydroxyvitamin D3 modulates Th17 polarization and interleukin-22 expression by memory $\mathrm{T}$ cells from patients with early rheumatoid arthritis. Arthritis Rheum. 2010;62:132-42.

72. Mattner F, Smiroldo S, Galbiati F, Muller M, Di Lucia P, Poliani PL, et al. Inhibition of Th1 development and treatment of chronic-relapsing experimental allergic encephalomyelitis by a non-hypercalcemic analogue of 1,25-dihydroxyvitamin D(3). Eur J Immunol. 2000;30:498-508.

73. Mayne CG, Spanier JA, Relland LM, Williams CB, Hayes CE. 1,25-Dihydroxyvitamin D3 acts directly on the $T$ lymphocyte vitamin $D$ receptor to inhibit experimental autoimmune encephalomyelitis. Eur J Immunol. 2011;41:822-32.

74. Smolders J, Thewissen M, Peelen E, Menheere P, Tervaert JW, Damoiseaux J, et al. Vitamin D status is positively correlated with regulatory $T$ cell function in patients with multiple sclerosis. PLoS One. 2009;4:e6635.

75. Hamzaoui K, Ben Dhifallah I, Karray E, Sassi FH, Hamzaoui A. Vitamin D modulates peripheral immunity in patients with Behcet's disease. Clin Exp Rheumatol. 2010;28:S50-7.

76. Baeke F, Korf H, Overbergh L, Verstuyf A, Thorrez L, Van Lommel L, et al. The vitamin D analog, TX527, promotes a human $\mathrm{CD} 4+\mathrm{CD} 25$ highCD127low regulatory $\mathrm{T}$ cell profile and induces a migratory signature specific for homing to sites of inflammation. J Immunol. 2011;186:132-42.

77. Smolders J, Menheere P, Thewissen M, Peelen E, Tervaert JW, Hupperts R, et al. Regulatory T cell function correlates with serum 25-hydroxyvitamin $D$, but not with 1,25-dihydroxyvitamin $D$, parathyroid hormone and calcium levels in patients with relapsing remitting multiple sclerosis. J Steroid Biochem Mol Biol. 2010;121:243-6.

78. Morales-Tirado V, Wichlan DG, Leimig TE, Street SE, Kasow KA, Riberdy JM. 1alpha,25 dihydroxyvitamin D3 (vitamin D3) catalyzes suppressive activity on human natural regulatory $\mathrm{T}$ cells, uniquely modulates cell cycle progression, and augments FOXP3. Clin Immunol. 2011;138:212-21.

79. Royal W, 3rd, Mia Y, Li H, Naunton K. Peripheral blood regulatory T cell measurements correlate with serum vitamin D levels in patients with multiple sclerosis. J Neuroimmunol. 2009;213:135-41. 
80. Smolders J, Peelen E, Thewissen M, Cohen Tervaert JW, Menheere P, Hupperts R, et al. Safety and T cell modulating effects of high dose vitamin D3 supplementation in multiple sclerosis. PLoS One. 2010;5:e15235.

81. Meehan MA, Kerman RH, Lemire JM. 1,25-Dihydroxyvitamin D3 enhances the generation of nonspecific suppressor cells while inhibiting the induction of cytotoxic cells in a human MLR. Cell Immunol. 1992;140:400-9.

82. Lysandropoulos AP, Jaquiery E, Jilek S, Pantaleo G, Schluep M, Du Pasquier RA. Vitamin D has a direct immunomodulatory effect on CD8+ T cells of patients with early multiple sclerosis and healthy control subjects. J Neuroimmunol. 2011;233:240-4.

83. Godfrey DI, MacDonald HR, Kronenberg M, Smyth MJ, Van Kaer L. NKT cells: what's in a name? Nat Rev Immunol. 2004;4:231-7.

84. Wu L, Van Kaer L. Natural killer T cells and autoimmune disease. Curr Mol Med. 2009;9:4-14.

85. Linsen L, Somers V, Stinissen P. Immunoregulation of autoimmunity by natural killer $\mathrm{T}$ cells. Hum Immunol. 2005;66:1193-202.

86. Yu S, Cantorna MT. The vitamin D receptor is required for iNKT cell development. Proc Natl Acad Sci U S A. 2008;105:5207-12.

87. Yu S, Cantorna MT. Epigenetic reduction in invariant NKT cells following in utero vitamin D deficiency in mice. J Immunol. 2011;186:1384-90.

88. Morandi B, Bramanti P, Bonaccorsi I, Montalto E, Oliveri D, Pezzino G, et al. Role of natural killer cells in the pathogenesis and progression of multiple sclerosis. Pharmacol Res. 2008;57:1-5.

89. French AR, Yokoyama WM. Natural killer cells and autoimmunity. Arthritis Res Ther. 2004;6:8-14.

90. Baxter AG, Smyth MJ. The role of NK cells in autoimmune disease. Autoimmunity. 2002;35:1-14.

91. Perricone R, Perricone C, De Carolis C, Shoenfeld Y. NK cells in autoimmunity: a two-edg'd weapon of the immune system. Autoimmun Rev. 2008;7:384-90.

92. Poggi A, Zocchi MR. Human natural killer lymphocytes through the engagement of natural cytotoxicity receptors and NKG2D can trigger self-aggression. Autoimmun Rev. 2007;6:295-9.

93. Merino F, Alvarez-Mon M, de la Hera A, Ales JE, Bonilla F, Durantez A. Regulation of natural killer cytotoxicity by 1,25-dihydroxyvitamin D3. Cell Immunol. 1989;118:328-36.

94. Mathieu C, Waer M, Laureys J, Rutgeerts O, Bouillon R. Prevention of autoimmune diabetes in NOD mice by 1,25 dihydroxyvitamin D3. Diabetologia. 1994;37:552-8.

95. Kankova M, Luini W, Pedrazzoni M, Riganti F, Sironi M, Bottazzi B, et al. Impairment of cytokine production in mice fed a vitamin D3-deficient diet. Immunology. 1991;73:466-71.

96. Kaneno R, Duarte AJ, Borelli A. Natural killer activity in the experimental privational rickets. Immunol Lett. 2002;81:183-9.

97. Balogh G, de Boland AR, Boland R, Barja P. Effect of 1,25(OH)(2)-vitamin $D(3)$ on the activation of natural killer cells: role of protein kinase $C$ and extracellular calcium. Exp Mol Pathol. 1999;67:63-74.

98. Kitajima I, Maruyama I, Matsubara H, Osame M, Igata A. Immune dysfunction in hypophosphatemic vitamin D-resistant rickets: immunoregulatory reaction of 1 alpha(OH) vitamin D3. Clin Immunol Immunopathol. 1989;53:24-31.

99. Leung $\mathrm{KH}$. Inhibition of human natural killer cell and lymphokine-activated killer cell cytotoxicity and differentiation by vitamin D3. Scand J Immunol. 1989;30:199-208.

100. Mariani E, Ravaglia G, Forti P, Meneghetti A, Tarozzi A, Maioli F, et al. Vitamin D, thyroid hormones and muscle mass influence natural killer (NK) innate immunity in healthy nonagenarians and centenarians. Clin Exp Immunol. 1999;116:19-27.

101. Mariani E, Ravaglia G, Meneghetti A, Tarozzi A, Forti P, Maioli F, et al. Natural immunity and bone and muscle remodelling hormones in the elderly. Mech Ageing Dev. 1998;102:279-92.

102. Quesada JM, Solana R, Martin A, Santamaria M, Serrano I, Martinez ME, et al. The effect of calcitriol on natural killer cell activity in hemodialyzed patients. J Steroid Biochem. 1989;34:423-5. 


\section{CHAPTER 2}

103. Ravid A, Koren R, Maron L, Liberman UA. 1,25(OH)2D3 increases cytotoxicity and exocytosis in lymphokine-activated killer cells. Mol Cell Endocrinol. 1993;96:133-9.

104. Rebut-Bonneton C, Demignon J. Effect of calcitriol on peripheral blood lymphocyte cytotoxicity. Biomed Pharmacother. 1991;45:369-72.

105. Deniz G, Erten G, Kucuksezer UC, Kocacik D, Karagiannidis C, Aktas E, et al. Regulatory NK cells suppress antigen-specific T cell responses. J Immunol. 2008;180:850-7.

106. Provvedini DM, Tsoukas CD, Deftos LJ, Manolagas SC. 1 alpha,25-Dihydroxyvitamin D3-binding macromolecules in human B lymphocytes: effects on immunoglobulin production. J Immunol. 1986;136:2734-40.

107. Iho S, Takahashi T, Kura F, Sugiyama H, Hoshino T. The effect of 1,25-dihydroxyvitamin D3 on in vitro immunoglobulin production in human B cells. J Immunol. 1986;136:4427-31.

108. Lemire JM, Adams JS, Sakai R, Jordan SC. 1 alpha,25-dihydroxyvitamin D3 suppresses proliferation and immunoglobulin production by normal human peripheral blood mononuclear cells. J Clin Invest. 1984;74:657-61.

109. Chen WC, Vayuvegula B, Gupta S. 1,25-Dihydroxyvitamin D3-mediated inhibition of human B cell differentiation. Clin Exp Immunol. 1987;69:639-46.

110. Heine G, Anton K, Henz BM, Worm M. 1alpha,25-dihydroxyvitamin D3 inhibits anti-CD40 plus IL-4mediated IgE production in vitro. Eur J Immunol. 2002;32:3395-404.

111. Shiozawa K, Shiozawa S, Shimizu S, Fujita T. 1 alpha,25-dihydroxyvitamin D3 inhibits pokeweed mitogen-stimulated human B-cell activation: an analysis using serum-free culture conditions. Immunology. 1985;56:161-7.

112. Matheu V, Back O, Mondoc E, Issazadeh-Navikas S. Dual effects of vitamin D-induced alteration of TH1/TH2 cytokine expression: enhancing IgE production and decreasing airway eosinophilia in murine allergic airway disease. J Allergy Clin Immunol. 2003;112:585-92.

113. Hypponen E, Berry DJ, Wjst M, Power C. Serum 25-hydroxyvitamin D and IgE - a significant but nonlinear relationship. Allergy. 2009;64:613-20.

114. Vieth R. Enzyme kinetics hypothesis to explain the U-shaped risk curve for prostate cancer vs. 25hydroxyvitamin D in nordic countries. Int J Cancer. 2004;111:468; author reply 9.

115. Spach KM, Nashold FE, Dittel BN, Hayes CE. IL-10 signaling is essential for 1,25-dihydroxyvitamin D3mediated inhibition of experimental autoimmune encephalomyelitis. J Immunol. 2006;177:6030-7.

116. Prietl B, Pilz S, Wolf M, Tomaschitz A, Obermayer-Pietsch B, Graninger W, et al. Vitamin D supplementation and regulatory $T$ cells in apparently healthy subjects: vitamin $D$ treatment for autoimmune diseases? Isr Med Assoc J. 2010;12:136-9.

117. Zold E, Szodoray P, Kappelmayer J, Gaal J, Csathy L, Barath S, et al. Impaired regulatory T-cell homeostasis due to vitamin D deficiency in undifferentiated connective tissue disease. Scand J Rheumatol. 2010;39:490-7.

118. Zold E, Szodoray P, Nakken B, Barath S, Kappelmayer J, Csathy L, et al. Alfacalcidol treatment restores derailed immune-regulation in patients with undifferentiated connective tissue disease. Autoimmun Rev. 2011;10:155-62.

119. Llewellyn DJ, Lang IA, Langa KM, Muniz-Terrera G, Phillips CL, Cherubini A, et al. Vitamin D and risk of cognitive decline in elderly persons. Arch Intern Med. 2010;170:1135-41.

120. Buell JS, Scott TM, Dawson-Hughes B, Dallal GE, Rosenberg IH, Folstein MF, et al. Vitamin D is associated with cognitive function in elders receiving home health services. J Gerontol A Biol Sci Med Sci. 2009;64:888-95.

121. Knippenberg S, Bol Y, Damoiseaux J, Hupperts R, Smolders J. Vitamin D status in patients with MS is negatively correlated with depression, but not with fatigue. Acta Neurol Scand. 2010.

122. Jongen MJ, van der Vijgh WJ, Lips $P$, Netelenbos JC. Measurement of vitamin D metabolites in anephric subjects. Nephron. 1984;36:230-4. 
123. Smolders J, Thewissen M, Theunissen R, Peelen E, Knippenberg S, Menheere P, et al. Vitamin D-related gene expression profiles in immune cells of patients with relapsing remitting multiple sclerosis. J Neuroimmunol. 2011.

124. Knippenberg S, Smolders J, Thewissen M, Peelen E, Cohen Tervaert JW, Hupperts R, Damoiseaux J. Effect of vitamin D3 supplementation on peripheral $B$ cell differentiation and isotype switching in patients with multiple sclerosis. Mult Scler. 2011 Dec;17(12):1418-23. 



\section{Chapter 3}

\section{Effect of vitamin D3 supplementation on peripheral B cell differentiation and isotype switching in patients with multiple sclerosis}




\section{CHAPTER 3}

\section{Abstract}

Background: Vitamin D has been proposed as a promoter of immune homeostasis in multiple sclerosis (MS). During the past decade, the focus of the effects of vitamin $D$ has been on dendritic cells and on T cells. Since there is an increasing interest in the role of B cells in the pathophysiology of MS, we studied the role of vitamin D on B cells in vivo in patients with MS.

Objective: We explored the effects of 12 weeks high-dose vitamin D3 supplementation on peripheral $B$ cell differentiation, immunoglobulin production and levels of $B$ cell activating factor (BAFF) in 15 patients with MS.

Methods: Circulating B cell subsets were characterized by flow cytometry. Plasma immunoglobulin levels were assessed by nephelometry. Plasma BAFF levels were assessed by enzyme-linked immunosorbent assay (ELISA).

Results: Although a significant increase serum 25-hydroxyvitamin D was induced, we found no significant shift in B cell differentiation, isotype switching, or plasma BAFF levels.

Conclusion: In patients with MS, supplementation of high doses vitamin D3 does not have substantial effects on phenotypic markers of $B$ cell differentiation in circulating B cells. Future studies may unravel more subtle changes in the B cell compartment, either in the circulation or in the central nervous system. 


\section{Introduction}

Multiple Sclerosis (MS) is an inflammatory disease of the central nervous system (CNS), which has been associated with a poor vitamin D status [1, 2]. Additionally, a poor vitamin D status has been associated with an increased risk of relapses in relapsing remitting MS (RRMS), and with high Expanded Disability Status Scale (EDSS) scores [35]. In vitro, the active metabolite of vitamin $D\left(1,25\right.$-dihydroxyvitamin $\left.D\left[1,25(\mathrm{OH})_{2} \mathrm{D}\right]\right)$ skews T cells to a less inflammatory profile [6]. Recent cross-sectional [7] and intervention studies $[8,9]$ show an interaction between vitamin D status (serum 25hydroxyvitamin $D[25(\mathrm{OH}) \mathrm{D}]$ levels) and $\mathrm{T}$ cell homeostasis in patients with RRMS. During recent years it has become evident that $\mathrm{B}$ cells play an important role in the disease process of MS $[10,11]$. This has been highlighted by the Rituximab trial, in which B cell depletion (anti-CD20) was an efficacious therapy in RRMS [12]. Recently, Hedegaard and colleagues showed that plasma levels of B cell activating factors (BAFF) correlated positively with the patient disability score (EDSS) [13]. Interestingly, B cells are also targets of vitamin $D$ in vitro. Exposure of activated $B$ cells to $1,25(\mathrm{OH})_{2} \mathrm{D}$ inhibits $B$ cell proliferation, promotes differentiation (CD38 expression), and inhibits isotype switching [14-17]. Whether systemic vitamin D status affects these B cell parameters in MS in vivo remains to be determined. In this study, we explored the effects of 12 weeks high-dose vitamin D3 supplementation on peripheral B cell subsets, plasma immunoglobulin levels and plasma BAFF levels in 15 patients with RRMS.

\section{Patients and Methods}

Fifteen RRMS patients (according to the 2005 McDonald criteria) were included in this study, and were supplemented for 12 weeks with 20,000 IU/day vitamin D3 (Vigantol Oil ${ }^{\circledR}$, Merck Serono, Darmstad, Germany). A detailed description of the intervention and safety-monitoring protocol has been published previously [9]. Plasma and serum were collected at week 0 and week 12 of the study. Samples were stored at $-20^{\circ} \mathrm{C}$. Plasma immunoglobulin levels were determined by nephelometry (Beckman-Coulter, Mijdrecht, Netherlands) according to standard procedure. Serum 25(OH)D levels were determined with a radioimmunoassay (Immunodiagnostic Systems, Boldon, UK) [4, 7]. The Quantikine enzyme-linked immunosorbent assay (ELISA) for human BAFF/BLyS (R\&D systems Europe Ltd, Abingdon, UK) was used to determine plasma BAFF levels, according to the manufacturer's protocol.

Peripheral blood mononuclear cells (PBMCs) were isolated by Ficoll gradient centrifugation. Directly after isolation, PBMCs were analysed by flow cytometry for the expression of four surface markers: CD19, IgD, CD38 and CD27. With these four surface markers, progress of peripheral B cell (CD19 ${ }^{+}$lymphocytes) differentiation can be assessed. The $\operatorname{lgD} / C D 38$ staining 


\section{CHAPTER 3}

provides the mature $B(B m)$ cell classification $(B m 1-B m 5)$, and the $I g D / C D 27$ staining provides information about differentiation in memory $B$ cells and the state of isotype switching $[18,19]$. Samples were measured on a FACS Canto II flow cytometer (BD Biosciences, Breda, Netherlands) and data were analyzed with FACS Diva software 6.1.2. (BD Biosciences).

\section{Results}

\subsection{Cohort}

Fifteen RRMS patients on beta-interferon treatment with a median age of 35 (27-43) years were included. They had suffered from MS for 3.5 (2.6-4.8) years, were relapsefree for $1.0(0.6-1.5)$ year, and had an EDSSscore of 2.0 (1.5-2.5). Patients were supplemented with 20,000 IU/day vitamin D3 for 12 weeks. A more detailed description of this cohort and intervention is provided elsewhere [9]. The serum 25(OH)D level at week 0 was 50 (33-94) nmol/l, and 380 (331-388) nmol/l after 12 weeks of vitamin D3 supplementation $(p<0.001)$.

\subsection{Effect of vitamin D3 supplementation on circulating B cell numbers}

Circulating $B$ cell phenotypes were assessed before (week 0 ) and after supplementation (week 12). The median proportion of $B$ cells $\left(\mathrm{CD} 19^{+}\right)$within the lymphocyte gate was $9.96 \%(6.30-12.55)$ at week 0 , and $9.85 \%(5.28-13.55)$ at week $12(P=0.650)$. The absolute number of $B$ lymphocytes in the circulation did not differ significantly between week 0 and week 12 (1.4 x 103 cells/ $\mu \mathrm{L}$ (0.7-2.4) and $1.4 \times 103$ cells $/ \mu \mathrm{L}$ (1.0-2.3), respectively; $\mathrm{P}=0.865$ ).

\subsection{Effect of Vitamin D3 supplementation on the circulating proportions of $B$ cell subsets}

$B$ cells were further characterized by CD27 and IgD expression (Figure 1A). The proportions of circulating naïve $\mathrm{CD} 19^{+} \mathrm{CD} 27^{-}$and memory $\mathrm{B}$ cells $\mathrm{CD} 19^{+} \mathrm{CD} 27^{+}$did not significantly change at week 12 (Figure 1B. The proportions of unswitched memory B cells $\left(\mathrm{CD} 19^{+} \mathrm{CD} 27^{+} \operatorname{lgD}{ }^{+}\right)$and switched memory $\mathrm{B}$ cells $\left(\mathrm{CD} 19^{+} \mathrm{CD} 27^{+} \mathrm{IgD}\right)$ also remained unaltered (Figure $1 \mathrm{~B}$ ), as well as their ratio (2.10 (1.36-3.23) vs. $1.86(1.40-3.45) ; \mathrm{P}=0.233)$. An alternative $B$ cell classification, the Bm1-Bm5 classification, is based on CD38 and IgD co-expression (Figure 1C). When week 0 and week 12 were compared, no differences were observed in the proportions of these B cell subsets (Figure 1D).

\subsection{Effect of vitamin D3 supplementation on circulating $\lg M / \lg G / \lg$ A levels}

Plasma concentrations of IgM, IgG, and IgA were assessed at week 0 and week 12 . No significant difference was observed for IgM, IgG and IgA. Additionally, IgG subclasses were measured. No significant change was observed for $\lg G 1$, IgG2, IgG3 and IgG4 (Table 1). 
Table 1. Immunoglobulin levels before and after vitamin D3 supplementation.

\begin{tabular}{llllll}
\hline $\operatorname{Ig}$ & Week & & Week 12 & & P-value \\
& Median & $($ IQR $)$ & Median & (IQR) & \\
\hline $\operatorname{IgM}(\mathrm{g} / \mathrm{L})$ & 1.6 & $(1.2-2.1)$ & 1.6 & $(1.2-1.9)$ & 0.510 \\
$\operatorname{IgA}(\mathrm{g} / \mathrm{L})$ & 2.0 & $(1.5-2.4)$ & 2.1 & $(1.6-2.5)$ & 0.490 \\
$\operatorname{IgG}(\mathrm{g} / \mathrm{L})$ & 10.4 & $(8.8-13.3)$ & 10.6 & $(8.4-12.4)$ & 0.660 \\
$\operatorname{IgG1}(\mathrm{g} / \mathrm{L})$ & 5.8 & $(5.1-7.5)$ & 5.9 & $(4.8-7.6)$ & 0.730 \\
$\operatorname{IgG2}(\mathrm{g} / \mathrm{L})$ & 3.2 & $(2.3-4.5)$ & 2.9 & $(2.5-4.4)$ & 0.925 \\
$\operatorname{IgG3}(\mathrm{g} / \mathrm{L})$ & 0.4 & $(0.3-0.5)$ & 0.3 & $(0.2-0.5)$ & 0.975 \\
$\operatorname{IgG4}(\mathrm{g} / \mathrm{L})$ & 0.4 & $(0.2-1.0)$ & 0.6 & $(0.1-1.0)$ & 0.683 \\
\hline
\end{tabular}

\subsection{Effect of vitamin D3 supplementation on plasma BAFF levels}

To examine B cell survival factors, BAFF levels were determined in plasma at week 0 and week 12. A trend was seen in the decrease of BAFF levels after 12 weeks vitamin D3 supplementation (1139.8 pg/mL (1015.2-1474.0) vs. $1022.1 \mathrm{pg} / \mathrm{mL}$ (845.9-1357.1); $P=0.08$ ) (Figure 2).

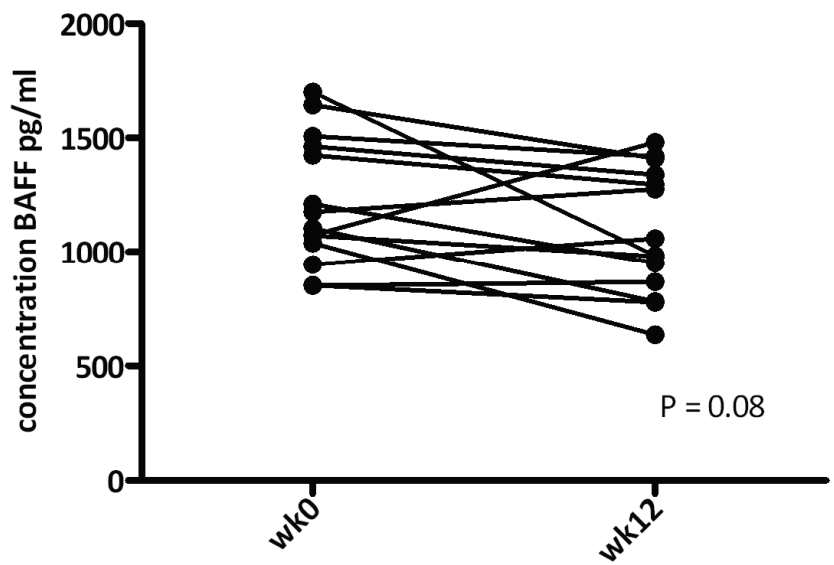

Figure 2. Plasma BAFF levels at week 0 and week 12. 


\section{CHAPTER 3}

A

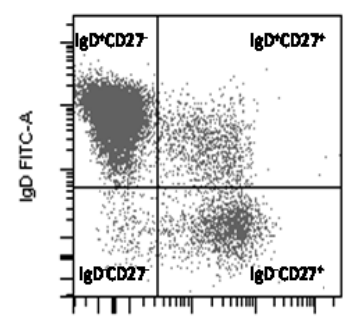

CD27 PE-A

\section{C}

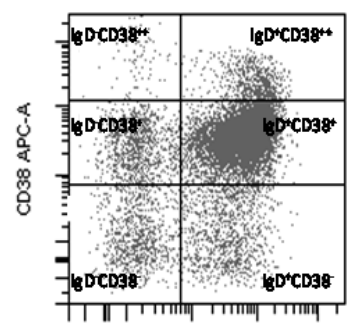

IgD FITC-A
B

\begin{tabular}{|c|c|c|c|}
\hline Subset & Week 0 & Week 12 & P-value \\
\hline $\lg \mathrm{O}^{+} \mathrm{CD} 27(\%)$ & $77.7(64.9-81.6)$ & $76.9(58.9-83.0)$ & 0.917 \\
\hline $\lg D^{+}+C_{2} 7^{+}(\%)$ & $75(3.2-9.3)$ & $7.2(3.9-17.6)$ & 0.116 \\
\hline $\lg 0 \mathrm{CO} 27^{+}(196)$ & $12.9(8.8-21.8)$ & $13.0(8.3-203)$ & 0.433 \\
\hline $\operatorname{lgDCD} 27(\%)$ & $4.0\{1.7-6.1\}$ & $4.0(1.8-7.5)$ & 0.701 \\
\hline $\operatorname{CD} 27^{+}(\%)$ & $20.7(15.6-38.2)$ & $19.6(13.5-35.3)$ & 0.950 \\
\hline $\operatorname{co} 27(\%)$ & $79.3(619-84.4)$ & $80.4(64.7-865)$ & 0.950 \\
\hline
\end{tabular}

D

\begin{tabular}{|c|c|c|c|}
\hline Subset & Week 0 & Week 12 & P-value \\
\hline $\lg 0^{+} \mathrm{CD} 38(\mathrm{Bm} 1)(\%)$ & $6.0(2.8-8.3)$ & $5.35(2.3-10.2)$ & 0.221 \\
\hline $\lg \mathrm{D}^{+} \mathrm{CD} 38^{+}(\mathrm{Bm} 2)(6)$ & $62.1(519-69.3)$ & $65.6(50.0-72.0)$ & 0.463 \\
\hline $\begin{array}{l}\lg \mathrm{O}^{+} \mathrm{CD} 38^{++}\left(\mathrm{Bm}^{\prime}\right) \\
(6)\end{array}$ & $9.9(5.9-21.8\}$ & $12.3(5.4-17.5)$ & 0.551 \\
\hline $\begin{array}{l}\operatorname{lgDCD} 38^{++}(\mathrm{Bm} 3- \\
\mathrm{Bm} 4)(\%)\end{array}$ & $1.7(0.8-2.6)$ & $1.2\{0.8-2.2\}$ & 0.198 \\
\hline $\operatorname{lgDCD} 38^{+}(\mathrm{Bm} 5)(\%)$ & $10.1(7.1-12.8)$ & $10.4(6.1-15.8)$ & 0.972 \\
\hline $\operatorname{lgDCD} 38(\mathrm{Bm} 5)(96)$ & $6.4(4.5-10.2)$ & $5.9(4.6-10.0)$ & 0.638 \\
\hline
\end{tabular}

Figure 1. Analysis of circulating B cell differentiation progression. A) B cells were characterized directly ex vivo by expression of $\operatorname{IgD}$ and $C D 27$, in which $B$ cells progress from naïve ( $\operatorname{gD}^{+}\left(\mathrm{CD}^{2} 7^{-}\right)$, to unswitched memory $\left(\operatorname{IgD} \mathrm{C}^{+} \mathrm{CD} 27^{+}\right)$, to switched memory $\mathrm{B}$ cells $\left(\operatorname{IgD}-\mathrm{CD} 27^{+}\right)$. B) The median proportions with corresponding interquartile range of the IgD/CD27 subsets, naïve B cells (CD27) and memory B cells (CD27 $7^{+}$) before (week 0$)$ and after (week 12) vitamin D3 supplementation. C) Characterization of B cells by co-expression of IgD and CD38, in which $B$ cells progress from virgin naïve $\left(B m 1: \lg D^{+} C D 38^{-}\right)$, to activated naïve $\left(B m 2: \operatorname{lgD}^{+} C D 38^{+}\right)$, to pregerminal center $\left(\mathrm{Bm}^{\prime}\right.$ : $\left.\operatorname{IgD}^{+} \mathrm{CD} 38^{++}\right)$, to germinal center $\left(\mathrm{Bm} 3-\mathrm{Bm}^{2}\right.$ : IgD $\left.\mathrm{CD}^{-} 8^{++}\right)$, to memory $\mathrm{B}$ cells (Bm5: IgD$\mathrm{CD} 8^{+} /$). D) The proportions of the IgD/CD38 subsets before and after vitamin D3 supplementation

\section{Discussion}

In this study, the effect of high-dose vitamin D3 supplementation on the peripheral B cell compartment was explored in RRMS patients. The number of $B$ cells was unaffected, as well as the proportions of $B$ cell subsets, the plasma levels of immunoglobulins and immunoglobulin subclasses. A small, but not significant, decrease of BAFF levels was observed during vitamin D3 supplementation. In short, we found only minor effects of 12 weeks of high-dose vitamin D3 supplementation on markers of differentiation and isotype switching of peripheral B cells and plasma BAFF levels in MS. The B cell plays an important pathophysiological role in MS. Intrathecal IgG synthesis has 
long been considered an important supportive criterion for the diagnosis MS [20]. Besides intrathecal IgG synthesis, B cell follicle-like structures are found in the meninges of MS patients [21]. Besides their most well-known function of antibody producing, $B$ cells are able to present antigens and they can influence $T$ cell responses by cytokine secretion [22]. Similar to the T cell compartment, B cells can be divided into subsets which produce different cytokines. While naïve $\left(C D 19^{+} C D 27^{+}\right) B$ cells were found to be the main producers of the anti-inflammatory cytokine interleukin (IL)-10, memory $\left(\mathrm{CD} 19^{+} \mathrm{CD} 27^{+}\right) \mathrm{B}$ cells produce more the pro-inflammatory cytokine IL-6 [23]. Although the $B$ cell differentiation markers used in our current study (CD19,IgD, CD38 and CD27) only detect larger shifts in $B$ cell subsets, in patients with systemic lupus erythematosus (SLE) and in primary Sjögren syndrome, a derangement of these circulating B cell subsets has been reported [24, 25]. In SLE patients, a reduced percentage of unswitched memory B cells was found compared with healthy controls. In addition, during active SLE, a skewed B cell differentiation profile was found compared with resting disease [25]. Although this derangement of the circulating B cell subsets was not associated with vitamin $D$ status, it suggests that the markers used are indeed able to detect shifts in the isolated circulating B cell subsets. In our study, however, there was no effect of vitamin D3 supplementation on the distribution of naïve and memory $B$ cell subsets as measured in isolated PBMCs. Additionally, we found no significant effect on isotype switching, that is, either in immunoglobulin levels in the plasma or IgD expression on memory B cells.

It is important to note that other B cell markers might be of interest to explore. Of particular interest are B1 cells, which produce natural antibodies and are associated with autoimmune diseases and $B$ lymphocyte proliferative disorders [26]. Recently, the phenotypic markers for human $B 1$ cells have been described in peripheral $B$ cells as $\mathrm{CD}_{20}{ }^{+} \mathrm{CD} 27^{+} \mathrm{CD}^{+} 3^{+} \mathrm{CD} 70[27]$.

Another exciting area to explore within the B cell compartment is the IL-10 producing regulatory $B$ cell. Recently, IL-10 production in B cells of MS patients was shown to be diminished [28]. Interestingly, in vitro experiments showed an increased IL-10 secretion by sorted $B$ cells exposed to $1,25(\mathrm{OH})_{2} \mathrm{D}$ after $\mathrm{CD} 40$ and $\mathrm{B}$ cell receptor (BCR) stimulation [29]. Our findings do not confirm in vitro studies showing that exposure of $B$ cells to $1,25(\mathrm{OH})_{2}$ D reduced isotype switching and immunoglobulin synthesis [14]. In addition, expression of CD38 was promoted. It is important to note that the in vitro experiments were predominantly done with $1,25(\mathrm{OH})_{2} \mathrm{D}$ and activated $\mathrm{B}$ cells, while our experiments were done with $25(\mathrm{OH}) \mathrm{D}$ and circulating $B$ cells, consisting for $<10 \%$ of activated $B$ cells (data not shown). It has been shown that resting $B$ cells express only negligible amounts of CYP27B1, necessary to convert 25(OH)D to $1,25(\mathrm{OH})_{2} \mathrm{D}$, and vitamin D receptor (VDR). However, upon activation, CYP27B1 and VDR are upregulated [30]. Direct effects of $25(\mathrm{OH}) \mathrm{D}$ in vivo might thus be restricted to recently activated $B$ cells $\left(\mathrm{CD} 69^{+}\right)$. The lack of effect of 25(OH)D on the phenotypic markers used, cannot be interpreted as a pertinent negative finding. Although in vivo a 


\section{CHAPTER 3}

more subtle effect of 25(OH)D on circulating B cells via vitamin D sensitive immune cells may still be possible, it would also be interesting to explore the effect of vitamin $D$ supplementation on the differentiation profile of recently activated B cells in future vitamin $D$ supplementation trials. Also, exploring the effect of vitamin $D$ supplementation on the expression of co-stimulatory molecules by B cells would be relevant, since activated $B$ cells are effective antigen presenting cells for $T$ cells in vitro [31, 32]. A trend towards a statistically significant decrease in BAFF levels after 12 weeks was observed. Whether this observation is a clinically relevant decrease and a direct effect of vitamin D3 supplementation is at present not clear. BAFF is a crucial factor in naïve $B$ cell and plasma cell survival, but is also an important co-stimulator of T cells. Human T cells exposed to BAFF respond by secreting interferon (IFN)-g and IL-2 and by upregulating CD25 [33]. Importantly, BAFF can be detected in the brain of patients with MS [34]. Therefore, a decrease in BAFF levels might be interesting in MS patients. Indeed, BAFF serum levels correlated with disability scores in MS patients, [13] therefore it could be suggested that BAFF might be a negative prognostic marker. Interestingly, in experimental autoimmune encephalitis (EAE), anti-BAFF treatment had a beneficial effect [35]. However, a phase II study in patients with MS had to be terminated because of disease worsening (www.clinicaltrials.gov; NCT00642902) and IFN- $\beta$ treatment on the other hand, increased plasma BAFF levels [36]. Therefore the role of BAFF in MS requires further study. There are several limitations of our data. First, the cohort studied is rather small. This might affect the results and, in particular, the trend towards a significant decrease in BAFF levels might be explained by a lack of power. Second, patients in our cohort received vitamin D3 supplementation for 12 weeks, which may be too short a time to measure effects on the B cell compartment and plasma BAFF levels. However, it should be mentioned that this supplementation was effective in altering the T cell compartment.9 Third, all patients were treated with IFN- $\beta$, thus our data may not apply to untreated MS patients or MS patients treated with other immune modulating therapies. IFN- $\beta$ was shown to interfere with peripheral $B$ cell subsets and $B$ cell functions [37, 38]. In addition, IFN- $\beta$ has been demonstrated to increase plasma BAFF levels in MS [36]. However, association studies on vitamin D3 and MS activity comprised mostly IFN- $\beta$ treated patients [3-5]. This suggests that the driving mechanism of beneficial effects of vitamin D3 is not abrogated by IFN- $\beta$. Moreover, since trials are exploring the role of vitamin $D$ as an add-on therapy in MS, [39] it is of particular interest to explore vitamin $D$ effects on $B$ cells in IFN- $B$ treated patients. Lastly, the interactions between vitamin D3 and B cells could be restricted to sites of B cell activation in MS, that is, the CNS. Indeed, a significant negative correlation has been shown between plasma 25(OH)D levels and cerebrospinal fluid IgG index [40].

Despite these limitations, this study assessed the effect of high-dose vitamin D3 supplementation on widely used B cell markers in MS, and provides directions for further research. In short, we did not find an effect of 12 weeks high-dose vitamin D3 supplementation on B cell differentiation and isotype switching in 15 RRMS patients. A 
trend towards lower BAFF levels was found. Further studies are needed to fully refute any in vivo effect of vitamin $D$ on $B$ cells. These include expression of co-stimulatory molecules, analysis of activated $B$ cells, investigation of functionally distinct $B$ cell subsets (B1 cells and Breg), and of B cells derived from the site of inflammation, the CNS. 


\section{CHAPTER 3}

\section{References}

1. Ascherio, A., K.L. Munger, and K.C. Simon, Vitamin D and multiple sclerosis. Lancet Neurol, 2010. 9(6): p. 599-612.

2. Smolders, J., et al., Vitamin $D$ as an immune modulator in multiple sclerosis, a review. J Neuroimmunol, 2008. 194(1-2): p. 7-17.

3. Simpson, S., Jr., et al., Higher 25 -hydroxyvitamin D is associated with lower relapse risk in multiple sclerosis. Ann Neurol, 2010. 68(2): p. 193-203.

4. Smolders, J., et al., Association of vitamin D metabolite levels with relapse rate and disability in multiple sclerosis. Mult Scler, 2008. 14(9): p. 1220-4.

5. van der Mei, I.A., et al., Vitamin D levels in people with multiple sclerosis and community controls in Tasmania, Australia. J Neurol, 2007. 254(5): p. 581-90.

6. Correale, J., M.C. Ysrraelit, and M.I. Gaitan, Immunomodulatory effects of Vitamin D in multiple sclerosis. Brain, 2009. 132(Pt 5): p. 1146-60.

7. Smolders, J., et al., Vitamin D status is positively correlated with regulatory $T$ cell function in patients with multiple sclerosis. PLoS One, 2009. 4(8): p. e6635.

8. Burton, J.M., et al., A phase $\mathrm{I} / \mathrm{Il}$ dose-escalation trial of vitamin D3 and calcium in multiple sclerosis. Neurology, 2010. 74(23): p. 1852-9.

9. Smolders, J., et al., Safety and T cell modulating effects of high dose vitamin D3 supplementation in multiple sclerosis. PLoS One, 2010. 5(12): p. e15235.

10. Dalakas, M.C., B cells as therapeutic targets in autoimmune neurological disorders. Nat Clin Pract Neurol, 2008. 4(10): p. 557-67.

11. Franciotta, D., et al., B cells and multiple sclerosis. Lancet Neurol, 2008. 7(9): p. 852-8.

12. Hauser, S.L., et al., B-cell depletion with rituximab in relapsing-remitting multiple sclerosis. $\mathrm{N}$ Engl $\mathrm{J}$ Med, 2008. 358(7): p. 676-88.

13. Hedegaard, C.J., et al., Interferon-beta increases systemic BAFF levels in multiple sclerosis without increasing autoantibody production. Mult Scler, 2010.

14. Chen, S., et al., Modulatory effects of 1,25-dihydroxyvitamin D3 on human B cell differentiation. J Immunol, 2007. 179(3): p. 1634-47.

15. Chen, W.C., B. Vayuvegula, and S. Gupta, 1,25-Dihydroxyvitamin D3-mediated inhibition of human B cell differentiation. Clin Exp Immunol, 1987. 69(3): p. 639-46.

16. Iho, S., et al., The effect of 1,25-dihydroxyvitamin D3 on in vitro immunoglobulin production in human B cells. J Immunol, 1986. 136(12): p. 4427-31.

17. Lemire, J.M., et al., 1 alpha,25-dihydroxyvitamin D3 suppresses proliferation and immunoglobulin production by normal human peripheral blood mononuclear cells. J Clin Invest, 1984. 74(2): p. 657-61.

18. Agematsu, K., et al., CD27: a memory B-cell marker. Immunol Today, 2000. 21(5): p. 204-6.

19. Pascual, V., et al., Analysis of somatic mutation in five B cell subsets of human tonsil. J Exp Med, 1994. 180(1): p. 329-39.

20. Kabat, E.A., M. Glusman, and V. Knaub, Quantitative estimation of the albumin and gamma globulin in normal and pathologic cerebrospinal fluid by immunochemical methods. Am J Med, 1948. 4(5): p. 65362.

21. Serafini, B., et al., Detection of ectopic B-cell follicles with germinal centers in the meninges of patients with secondary progressive multiple sclerosis. Brain Pathol, 2004. 14(2): p. 164-74.

22. Bar-Or, A., et al., Abnormal B-cell cytokine responses a trigger of T-cell-mediated disease in MS? Ann Neurol, 2010. 67(4): p. 452-61.

23. Duddy, M., et al., Distinct effector cytokine profiles of memory and naive human B cell subsets and implication in multiple sclerosis. J Immunol, 2007. 178(10): p. 6092-9. 
24. Binard, A., et al., Is the blood B-cell subset profile diagnostic for Sjogren syndrome? Ann Rheum Dis, 2009. 68(9): p. 1447-52.

25. Sanz, I., et al., Phenotypic and functional heterogeneity of human memory B cells. Semin Immunol, 2008. 20(1): p. 67-82.

26. Youinou, P. and Y. Renaudineau, The paradox of CD5-expressing B cells in systemic lupus erythematosus. Autoimmun Rev, 2007. 7(2): p. 149-54

27. Griffin, D.O., N.E. Holodick, and T.L. Rothstein, Human B1 cells in umbilical cord and adult peripheral blood express the novel phenotype $C D 20^{+} \mathrm{CD} 27^{+} \mathrm{CD} 43^{+}$CD70. J Exp Med, 2011. 208(1): p. 67-80.

28. Hirotani, M., et al., Decreased IL-10 production mediated by Toll-like receptor 9 in B cells in multiple sclerosis. J Neuroimmunol, 2010. 221(1-2): p. 95-100

29. Heine, G., et al., 1,25-dihydroxyvitamin $\mathrm{D}(3)$ promotes $\mathrm{IL}-10$ production in human $\mathrm{B}$ cells. Eur J Immunol, 2008. 38(8): p. 2210-8.

30. Provvedini, D.M., et al., 1,25-dihydroxyvitamin D3 receptors in human leukocytes. Science, 1983. 221(4616): p. 1181-3.

31. Ho, W.Y., et al., Resting and anergic B cells are defective in CD28-dependent costimulation of naive CD4 $^{+}$T cells. J Exp Med, 1994. 179(5): p. 1539-49.

32. Metlay, J.P., E. Pure, and R.M. Steinman, Control of the immune response at the level of antigenpresenting cells: a comparison of the function of dendritic cells and B lymphocytes. Adv Immunol, 1989. 47: p. 45-116.

33. Schneider, P., The role of APRIL and BAFF in lymphocyte activation. Curr Opin Immunol, 2005. 17(3): p. 282-9.

34. Krumbholz, M., et al., BAFF is produced by astrocytes and up-regulated in multiple sclerosis lesions and primary central nervous system lymphoma. J Exp Med, 2005. 201(2): p. 195-200.

35. Huntington, N.D., et al., A BAFF antagonist suppresses experimental autoimmune encephalomyelitis by targeting cell-mediated and humoral immune responses. Int Immunol, 2006. 18(10): p. 1473-85.

36. Krumbholz, M., et al., Interferon-beta increases BAFF levels in multiple sclerosis: implications for B cell autoimmunity. Brain, 2008. 131(Pt 6): p. 1455-63.

37. Niino, M., et al., Memory and naive B-cell subsets in patients with multiple sclerosis. Neurosci Lett, 2009. 464(1): p. 74-8.

38. Ramgolam, V.S., et al., B Cells as a Therapeutic Target for IFN-\{beta\} in Relapsing-Remitting Multiple Sclerosis. J Immunol, 2011. 186(7): p. 4518-26.

39. Smolders, J., et al., Efficacy of vitamin $\mathrm{D}(3)$ as add-on therapy in patients with relapsing-remitting multiple sclerosis receiving subcutaneous interferon beta-1a: a Phase II, multicenter, double-blind, randomized, placebo-controlled trial. J Neurol Sci, 2011. 311(1-2): p. 44-9.

40. Vogt, M.H., et al., Increased osteopontin plasma levels in multiple sclerosis patients correlate with bone-specific markers. Mult Scler, 2010. 16(4): p. 443-9. 



\section{Chapter 4}

\section{Reduction in IL-10 producing B cells (Breg) in multiple sclerosis is accompanied by a reduced naïve/memory Breg ratio during a relapse but not in remission}




\section{CHAPTER 4}

\section{Abstract}

In this study, we assessed B cell subsets, including Bregs, during stable and active disease in relapsing remitting multiple sclerosis (RRMS) patients and related $B$ cell subsets to vitamin D status. We report that RRMS patients have a decreased percentage of both memory B cells and Bregs compared to healthy controls. During a relapse, the reduction in Bregs involved in particular naïve Bregs. We found no correlation between vitamin D status and B cell subsets. An effect of vitamin D on Bregs cannot be ruled out, since it might be the function that is interfered with instead of relative numbers. 


\section{Introduction}

Multiple sclerosis (MS) is a chronic inflammatory disease of the central nervous system, which is considered to be a T cell mediated autoimmune disease [1]. However, a growing body of evidence emphasizes the importance of B cells in the pathogenesis of MS. Clinical trials with the $B$ cell depleting drug, Rituximab, demonstrated a positive effect on disease activity in MS [2]. B cells may be involved at different stages of the pathogenesis of MS. They can contribute by producing antibodies, by functioning as antigen presenting cells or by secreting cytokines. Recently, it was demonstrated that Rituximab inhibits T helper (Th) 17 cell response, suggesting that B cells are able to modulate the pathogenic Th17 response [3]. Similar to the T cell compartment, different $B$ cell subsets can be recognized, but their exact contribution to MS pathogenesis has not been thoroughly investigated yet. It is now generally recognized that B cell subsets may be discriminated by the production of different effector cytokines. While memory B cells are more easily activated to differentiate into plasma cells and to secrete pro-inflammatory cytokines such as tumor necrosis factor- $\alpha$ (TNF- $\alpha$ ) and interleukin (IL)- 6, naïve B cells preferentially produce the anti-inflammatory cytokine IL-10 [4]. Studies in experimental autoimmune encephalomyelitis (EAE), the animal model of MS, revealed that $B$ cells regulate the disease process by secreting IL-10 [5]. Recently, these data were extrapolated to the human situation where IL-10 producing B cells (Breg) were found to have regulatory properties in reducing the frequency of TNF- $\alpha^{+}$ and IFN $-\gamma^{+} \mathrm{CD}^{+}{ }^{+}$cells [6] and inhibiting T cell proliferation [7]. Strikingly, B cells of MS patients showed a diminished IL-10 secretion, suggesting that a defect of these cells is implicated in MS $[4,8]$.

One of the factors contributing to a poor Breg function in MS could be a poor vitamin D status. Both MS incidence and MS disease activity have been associated with vitamin $D$ status $[9,10]$. Interestingly, in mice treated with the biologically active metabolite of vitamin $\mathrm{D}, 1,25$-hihydroxyvitamin $\mathrm{D}\left(1,25(\mathrm{OH})_{2} \mathrm{D}\right)$, the induction of EAE was inhibited. IL-10 producing RAG1 dependent cells appeared crucial in this inhibition [11, 12]. Although regulatory $T$ cells (Tregs) meet these criteria and have been the focus of vitamin D research [13], Bregs also fulfill these criteria. Indeed, B cells have been shown to increase IL-10 secretion after exposure to $1,25(\mathrm{OH})_{2} \mathrm{D}$ in vitro [14]. At present, data on the association between Breg and vitamin $\mathrm{D}$ status in vivo are lacking.

In the current study we first explored peripheral B cell subsets, including Bregs, in MS patients during remission and during active disease versus healthy controls. Since it is hypothesized that the naïve and memory Breg subsets have distinct roles in autoimmune diseases [15], we discriminated between these two Breg subsets. Finally, we explored the association between $B$ cell subsets and vitamin D status. 


\section{CHAPTER 4}

\section{Material and methods}

\subsection{Subjects}

Twenty-three RRMS patients during remission and 22 RRMS patients during relapse were included. In addition, 30 healthy controls (HC) matched for age and sex with RRMS patients in remission were included. All MS patients fulfilled the 2005 McDonald criteria and had an age $>18$ years. Patients were either treated with interferon beta $1 \mathrm{a}$ or $1 \mathrm{~b}$ or did not use any other immune modulating drugs. RRMS patients in remission had to be relapse free for more than 6 weeks. A relapse was defined as the appearance of one or more new neurological abnormalities or the reappearance of one or more previously observed neurological abnormalities and which required treatment with methylprednisolone. This change in clinical state lasted at least $24 \mathrm{~h}$ and blood sampling of all relapse patients, included in this study, was done prior to intravenous methylprednisolone treatment. Eight patients in remission and 3 patients in relapse participated in a high dose vitamin D supplementation study in the year before inclusion to this study [16]. These patients were included in order to potentially enlarge the range of vitamin D status in the cohort. A proportion of RRMS patients in relapse ( $n=$ 7) was re-evaluated while in remission ( $\geq 6$ weeks). Use of immune modulation other than interferon beta $1 \mathrm{a}$ or $1 \mathrm{~b}$ was an exclusion criterion for this re-evaluation. The characteristics of all subjects are described in Table 1.

Table 1. Patient characteristics

\begin{tabular}{|c|c|c|c|c|}
\hline & & $\begin{array}{l}\text { Healthy controls } \\
(n=30)\end{array}$ & $\begin{array}{l}\text { RRMS in remission } \\
(n=23)\end{array}$ & $\begin{array}{l}\text { RRMS in relapse } \\
(n=22)\end{array}$ \\
\hline & & Median (IQR)/N (\%) & Median (IQR)/N (\%) & Median (IQR)/N (\%) \\
\hline Sex & Female & $N=22(73 \%)$ & $\mathrm{N}=16(70 \%)$ & $\mathrm{N}=12(55 \%)$ \\
\hline & Male & $N=8(27 \%)$ & $\mathrm{N}=7(30 \%)$ & $\mathrm{N}=10(45 \%)$ \\
\hline Age (years) & & $41.0(30.8-47.3)$ & $37.0(29.0-46.0)$ & $32.0(28.0-40.0)$ \\
\hline MS duration & & - & $3.8(3.4-4.6)$ & $2.3(0.5-4.8)$ \\
\hline $\operatorname{ARR}(N)^{*}$ & & - & $0.0(0.0-1.0)$ & $1.0(0.5-1.0)$ \\
\hline Time since las & lapse (years) & & $1.8(0.7-3.8)$ & $1.0(0.6-1.5)$ \\
\hline EDSS score** & & - & $1.5(1.0-3.0)$ & $2.5(1.0-2.5)$ \\
\hline medication & none & - & $\mathrm{N}=4(17 \%)$ & $N=9(41 \%)$ \\
\hline & Beta Interferon & - & $N=19(83 \%)$ & $N=13(59 \%)$ \\
\hline Vitamin D sta & $\mathrm{nmol} / \mathrm{L})$ & $87.5(43.0-128)$ & $107.0(77.0-128.0)$ & $66.5(47.3-100.5)$ \\
\hline Vitamin D sta & nmol/L) non- & - & 99.0 (66.0-119.0) & $66.0(48.0-102.0)$ \\
\hline supplemente & & & $\mathrm{N}=15$ & $\mathrm{~N}=19$ \\
\hline Vitamin D sta & $\mathrm{nmol} / \mathrm{L})$ & - & $133.0(91.5-224.5)$ & $82.0(25.0-87.0)$ \\
\hline supplemente & & & $\mathrm{N}=8$ & $N=3$ \\
\hline
\end{tabular}

*ARR $=$ Annualized relapse rate ${ }^{* * E D S S}=$ Expanded disability status scale 
Written informed consent was acquired from all subjects participating in this study, according to the declaration of Helsinki. The study was reviewed and approved by both the regional ethical committee on human research 'Atrium-Orbis-Zuyd', and the institutional ethical committee 'Local Advisory board on Scientific Research'.

\subsection{Blood collection and vitamin $D$ assays}

Blood withdrawal was performed simultaneously for cells for the cellular assays and serum for vitamin D measurement in the period from January 2010 to July 2010. Serum was collected immediately after blood sampling and stored at $-20{ }^{\circ} \mathrm{C}$. To determine vitamin $D$ status, all samples were analyzed simultaneously for 25-hydroxyvitamin $\mathrm{D}(25(\mathrm{OH}) \mathrm{D})$ levels at the end of the study with a commercially available radioimmuno assay (Immunodiagnostic Systems, Boldon, UK).

\subsection{Cell isolation and cell cultures}

Peripheral blood mononuclear cells (PBMC) were isolated by Ficoll gradient centrifugation (Histopaque; Sigma Aldrich, Zwijndrecht, The Netherlands). Isolated PBMC were cultured in complete RPMI glutamax medium (Gibco Invitrogen, Breda, The Netherlands) supplemented with $10 \%$ Fetal Calf Serum (Greiner BioOne, Alphen a/d Rijn, The Netherlands), $1 \%$ non-essential amino acids (Gibco Invitrogen), 1\% sodium pyruvate (Gibco Invitrogen) and 2\% penicillin-streptomycin (Gibco Invitrogen). The absolute number of lymphocytes was determined with a hematological cell counter (Beckman Coulter, Woerden, The Netherlands).

\subsection{B cell phenotyping}

Directly after PBMC isolation, B cells (CD19 ${ }^{+}$lymphocytes) were analyzed for the expression of 4 surface markers by flow cytometry using fluorescently labeled antibodies: anti-CD19-PerCP-cy5.5, anti- IgD-FITC, anti-CD38-APC and anti-CD27-PE (BD Biosciences, Breda, the Netherlands). With these 4 surface markers, peripheral $B$ cell differentiation can be assessed. The IgD/CD38 staining enables to differentiate mature $B(B m)$ cells according to the Bm1-Bm5 classification, and the $\operatorname{IgD} / \mathrm{CD} 27$ staining provides information about isotype switching and memory formation [17, 18]. Additionally, circulating $\mathrm{CD} 19^{+}$cells were analyzed for the expression of $\mathrm{CD} 27$ and $\mathrm{CD} 38$, which was used to identify transitional B cells (CD27 $7^{-}$D $\left.38^{\text {high }}\right)$ and plasma cells (CD27 ${ }^{\text {high }} \mathrm{CD} 38^{\text {high }}$ ) [19].

For the detection of IL-10 producing B cells, PBMC were cultured at a density of 1 $\times 106$ cells per well in 24-well, flat-bottom plates. PBMC were cultured in the presence of $0.1 \mu \mathrm{M} \mathrm{CpG}$ oligodeoxynucleotide 2006 (Invivogen, Toulouse, France) for $66 \mathrm{~h}$ followed by re-stimulation during $6 \mathrm{~h}$ with $5 \mathrm{ng} / \mathrm{mL}$ phorbol 12-myristate 13-acetate (PMA; Sigma Aldrich) and Ionomycin $(0.5 \mu \mathrm{g} / \mathrm{mL}$ ). Brefeldin A (Sigma Aldrich, 0.5 $\mu \mathrm{g} / \mathrm{mL}$ ) was added to the culture to block cytokine excretion. IL-10 production by B cells was then determined by assessing intracellular IL-10 of viable (7AAD $\left.{ }^{-}\right) \mathrm{CD}^{+} 9^{+}$lymphocytes. Cells were stained extra-cellularly with anti-CD3-horizon 450 (BD Bioscienc- 


\section{CHAPTER 4}

es), anti- CD19-FITC (Biolegend), and intra-cellularly with anti-IL-10-APC (Biolegend), and anti-CD69-PECy7 (Biolegend). Anti-CD69 was used as activation control of the B cells. Samples were measured on a FACS Canto II flowcytometer and data were analyzed with FACS Diva software 6.1.2.

\subsection{Statistical analysis}

Statistical analysis was conducted with SPSS version 17.0 software (SPSS inc., Chicago IL, USA) and figures were constructed with GraphPad Prism 5 software (GraphPad Software inc., La Jolla CA, USA). Of continuous variables, the median and corresponding interquartile (IQR) range are provided. For assessment of correlations, the Spearman correlation coefficient was calculated. The Man Whitney $U$ test was used for unpaired testing and the Wilcoxon signed ranks test was used for paired testing. A Pvalue $<0.05$ was considered statistically significant.

\section{Results}

\subsection{Circulating memory B cells are decreased in RRMS patients in remission compared to healthy controls}

Circulating B cell subsets were phenotyped directly after PBMC isolation in all subjects. No difference was observed in the absolute amount of circulating $B$ cells between $\mathrm{HC}$ $[0.9 \times 103 / \mu \mathrm{l}(0.6-1.4)]$ and RRMS patients during remission $[0.9 \times 103 / \mu \mathrm{l}(0.6-1.3)(\mathrm{P}=$ 0.247)]. B cells were further characterized by CD27 and IgD expression (Fig. 1A). A significant decrease in memory $B$ cells $\left(C D 19^{+} C D 27^{+}\right)$was seen in RRMS patients in remission [20.7\% (14.6-37.1)] compared to HC [35.1\% (23.2-42.8), $\mathrm{P}=0.017]$. In particular the proportion of switched memory $B$ cells $\left(C D 19^{+} C D 27^{+} \mid g^{-}\right)$was lower in RRMS patients in remission compared to $\mathrm{HC}[9.5 \%$ (7.3- 14.5) vs. $15.1 \%(11.1-23.2) ; \mathrm{P}=$ 0.005]. An alternative $B$ cell classification is based on CD38 and IgD expression (Fig. 1B). This classification also showed a relative increase in the naïve $B$ cell subset $B m 2$ $\left[\operatorname{lgD}^{+} \mathrm{CD} 38^{+} ; 57.1 \%(49.7-63.2)\right.$ vs. $\left.73.5 \%(58.8-77.2), \mathrm{P}=0.001\right]$ and a reduction in the memory B cell subset Bm5 [(IgD'CD38- $11.4 \%$ (8.0-13.8) vs. 6.2\% (4.0-9.7), $P=0.001]$ in RRMS patients during remission compared to HC (Table 2). Interestingly, the decrease in memory $B$ cells subsets was accompanied by a relative increase in transitional $B$ cells $\left(C D 19^{+} \mathrm{CD} 27^{-} \mathrm{CD} 38^{++}\right)$in RRMS patients compared to healthy controls $[1.1 \%$ $(0.8-1.7)$ vs. 3.1 (1.5-5.9), $P=0.001$ ] (Table 2). There were no significant differences in the proportions of $B$ cell subsets between IFN- $\beta$ treated and untreated MS patients (data not shown). 

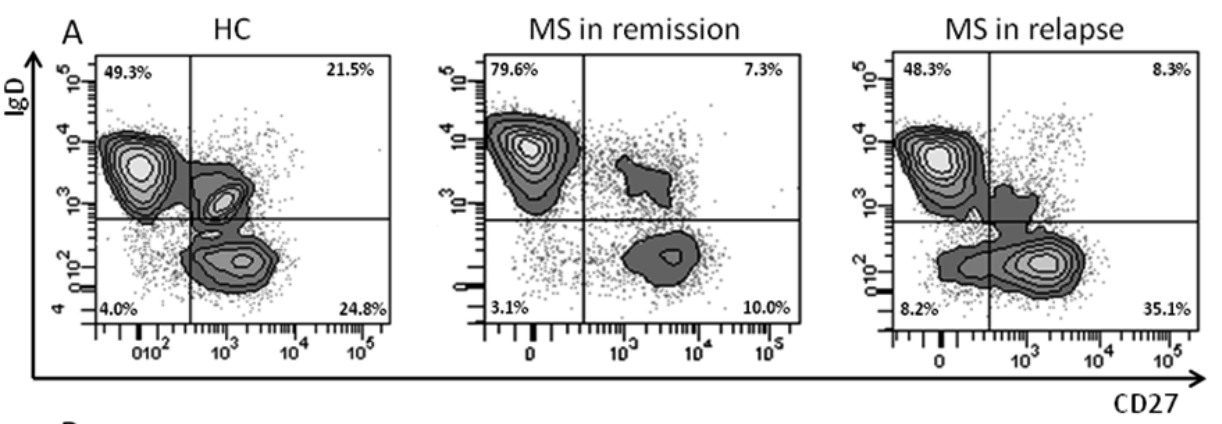

$B$
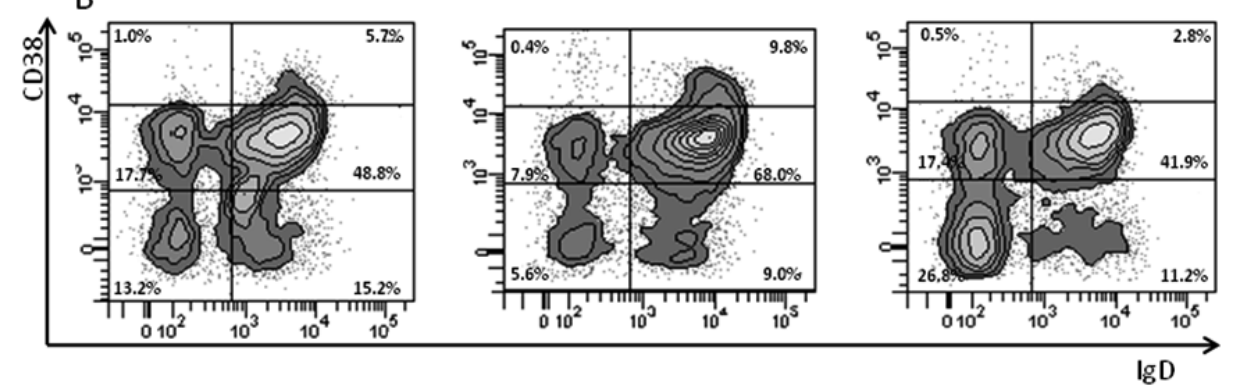

Figure 1. Analysis of circulating B cell phenotypes. A) B cells were characterized directly ex vivo by coexpression of $\operatorname{IgD}$ and $C D 27$. $B$ cells progress from naïve (IgD $\left.{ }^{+} C D 27\right)$, to unswitched memory $\left(\operatorname{IgD}{ }^{+} C D 27^{+}\right)$, to switched memory $B$ cells $\left(\operatorname{IgD} C D 27^{+}\right)$. B) Characterization of $B$ cells by co-expression of IgD and CD38. $B$ cells progress from virgin naïve $\left(B m 1\right.$ : $\left.\lg D^{+} C D 38-\right)$, to naïve $\left(B m 2: \operatorname{lgD}{ }^{+} C D 38^{+}\right)$, to pre-germinal center $\left(B m 2^{\prime}\right.$ :

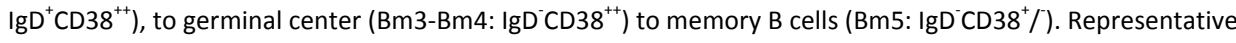
flow panels are shown for HC, RRMS in remission and RRMS during a relapse.

\subsection{Circulating $B$ cell subsets are not different during a relapse compared to RRMS patients in remission}

$B$ cell phenotypes of RRMS patients during remission were compared with B cell phenotypes of RRMS patients during a relapse. No difference was observed in the absolute amount of circulating $B$ cells between RRMS patients in remission $[0.9 \times 103 / \mu \mathrm{l}(0.6-$ $1.3)]$ and RRMS patients in a relapse $[1.3 \times 103 / \mu \mathrm{l}(0.6-1.7)$ vs. $P=0.162]$. Additionally, besides a relative increase in late memory $B$ cells $(B m 5), B$ cell subsets according to the $\mathrm{CD} 27 / \mathrm{IgD}$ and $\mathrm{CD} 38 / \mathrm{IgD}$ classification were statistically not different during a relapse compared to RRMS patients in remission (Table 2).

\subsection{The proportion of naïve Breg is diminished during relapse}

IL-10 production by B cells was assessed by intracellular IL-10 staining after 3 days of culture in the presence of CpG-DNA. The median percentage of IL-10 $0^{+}$cells within viable $\mathrm{CD}_{19}{ }^{+} \mathrm{B}$ cells was $4.4 \%(3.1-6.1)$ in $\mathrm{HC}, 1.4 \%(0.8-2.0)$ in RRMS patients in remission and $1.6 \%(0.8-2.7)$ in RRMS patients during relapse ( $P \leq 0.001)$ (Fig. $2 A)$. Next, the 


\section{CHAPTER 4}

proportion naïve $\left(\mathrm{CD} 27^{-}\right)$and memory $\left(\mathrm{CD} 27^{+}\right)$cells within the Breg $\left(\mathrm{CD} 19^{+} \mathrm{IL} 10^{+}\right)$population was determined (Fig. 2B). In $\mathrm{HC}$ and in $\mathrm{MS}$ patients in remission, the majority of Bregs had a naïve phenotype [63.3\% (47.8-74.3) and 61.1\% (42.9-69.0), $\mathrm{P}=0.753$ ]. Strikingly, only $11.2 \%(2.7-46.0)$ ( $P \leq 0.001$ ) of the Breg in RRMS patients during relapse had a naïve phenotype (Fig. $2 \mathrm{C}$ ). In 7 relapse patients, measurements were repeated during subsequent remission. The reduction in naïve Breg proportion was restored during subsequent stable disease [6.3\% (3.2-47.5) vs. $75.4 \%$ (65.2-77.5) (Fig. 2D).


Figure 2. Analysis of intracellular IL-10 in B cells. A) The proportion of Breg (IL-10+ viable B cells) in HC, RRMS patients during remission and during relapse. Open dots represent vitamin $D$ supplemented patients; closed dots represent vitamin D unsupplemented patients. B) Representative examples of IL-10 production in naïve and memory $B$ cells in healthy controls and MS patients during relapse. Isolated PBMC were analyzed after 3 days CpG ODN 2006 stimulation. The last 6 hours PMA, ionomycin and brefelidin-A were added. PBMC were then analyzed by flow cytometry. $\mathrm{CD}^{-} \mathrm{CD} 19^{+}$lymphocytes were assessed in viable (7AAD) singlets lymphogate. Expression of CD27 was analyzed to phenotype naïve (CD27-) and memory (CD27 ${ }^{+}$) cells. C) The percentage of naïve $\mathrm{IL}-10^{+} \mathrm{B}$ cells $\left(\mathrm{CD} 3^{-} \mathrm{CD} 19^{+} \mathrm{CD} 27^{-}\right)$in $\mathrm{HC}$, in RRMS patients during remission and in RRMS patients during relapse. D) The percentage of naive $\mathrm{IL}-10^{+} \mathrm{B}$ cells in RRMS patients in relapse and during subsequent remission. Significance was assessed with the Man Whitney $U$ test for unpaired testing, and the Wilcoxon signed-ranks test was used for paired testing.

\subsection{Vitamin D status does not correlate with B cell subsets or Breg}

To determine vitamin D status, serum levels of 25(OH)D were assessed. The median 25(OH)D level was $107.0 \mathrm{nmol} / \mathrm{L}(77.0-128.0)$ in RRMS patients in remission, 66.5 
$\mathrm{nmol} / \mathrm{L}(47.3-100.1)$ in RRMS patients in a relapse and $87.5 \mathrm{nmol} / \mathrm{L}(67.5-95.0)$ in $\mathrm{HC}$. The $25(\mathrm{OH}) \mathrm{D}$ values of RRMS patients in remission included vitamin $\mathrm{D}$ supplemented patients and were significantly higher compared to $\mathrm{HC}(P=0.012)$. However, there was no significant difference in 25(OH)D levels between non-supplemented RRMS patients in remission and $\mathrm{HC}(P=0.120)$. Interestingly, levels of 25(OH)D of RRMS patients in relapse were lower compared to RRMS patients in remission $(P=0.002$ when patients supplemented were included in analysis vs. $P=0.051$ when patients supplemented were excluded from analysis). Correlations between $B$ cell subsets and vitamin $D$ status were assessed. B cell subsets did not correlate with vitamin D status in HC, or RRMS patients in remission or in relapse (data not shown). In addition, there was no correlation between the percentage of Bregs and vitamin D status overall (Fig. 3), nor in the subgroups in HC $(R=-0.082, P=0.665)$, non-supplemented RRMS patients in remission $(R=0.238, P=0.393)$ and non-supplemented RRMS patients in relapse $(R=0.125$, $P=0.611$ ). Finally, no correlation was found between vitamin $D$ status and the proportions of naïve or memory Breg in HC or RRMS patients (data not shown).



Figure 3. Correlation between Breg and vitamin D status. The correlation between serum 25-hydroxyvitamin $\mathrm{D}(25(\mathrm{OH}) \mathrm{D})$ values and the percentage of Breg in the whole cohort is shown. Correlations between $25(\mathrm{OH}) \mathrm{D}$ and percentage of Breg in the different cohorts are described in the results section. Open dots represent healthy controls, closed dots represent RRMS patients in remission and triangles represent RRMS patients during a relapse. Spearman correlation coefficient is shown. 


\section{CHAPTER 4}

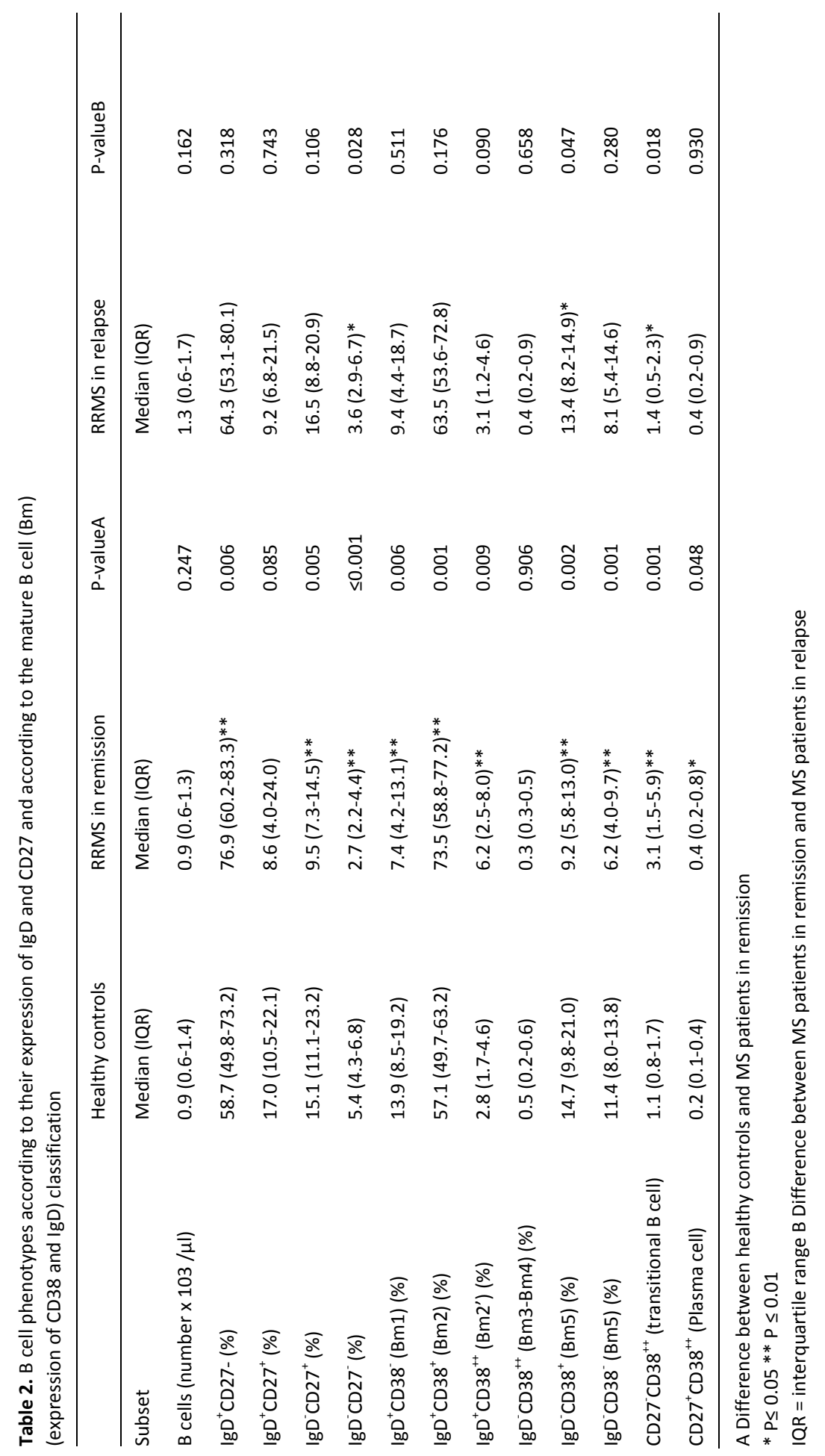




\section{Discussion}

The main findings of the current study are fourfold. First, RRMS patients in remission have a relative decrease in circulating memory B cells as compared to HC. Second, in RRMS patients the relative amount of IL-10 producing B cells (Bregs) is significantly decreased. Third, in RRMS patients during a relapse, but not in RRMS patients in remission, there is a shift in the naïve/memory Breg ratio in favor of memory Bregs. Fourth, we could not demonstrate any correlation between Bregs and vitamin D status.

In MS patients in remission we demonstrated a decrease in memory B cells in peripheral blood, in particular of switched memory $B$ cells. Whether this change in naïve/memory $B$ cell ratio reflects a cause or a consequence of the disease is at present not clear. Recently, it was shown that switched memory B cells express high levels of $\alpha-4$ integrin compared to naïve B cells [20]. Therefore, the decrease in switched memory $B$ cells in peripheral blood may be caused by the migration of these cells towards the site of inflammation, i.e., the CNS. Indeed, switched memory B cells were found to be highly enriched in cerebrospinal fluid (CSF) of MS patients [21, 22]. Although the disease status of these patient cohorts was not defined in the respective papers, it is most likely that the CSF was obtained during remission. In addition, a disproportionate increase in B cells in the peripheral blood was shown following natalizumab (an antibody blocking $\alpha-4$ integrin) treatment in RRMS patients. However, the proportions of naïve and memory B cells were not measured in these studies [23, 24]. Since interferon beta has been reported to decrease the percentage of memory $B$ cells in MS patients [25], the observed decrease might, alternatively, also be induced by interferon beta treatment. Indeed, in our study 19/23 MS patients in remission were treated with interferon beta. In MS patients with active disease the B cell differentiation profile was statistically not different from the profile of MS patients in remission. However, in particular the percentages of circulating naïve and memory $B$ cells do resemble more the situation as is seen in $\mathrm{HC}$. This is surprising, because it is to be expected that, especially during active disease, memory $B$ cells migrate to the target tissue. Our finding might first be explained by a difference in interferon beta treatment between the remission and relapse cohort. While 19/23 (83\%) MS patients in remission where on interferon beta treatment, only 13/22 (59\%) MS patients with active disease were treated with interferon beta. Second, it is evident that the presence of $B$ cell subsets in the circulation is not only dependent on the migration towards the target tissue, but also on the continuous exchange between the peripheral blood and the secondary lymphoid tissues. The latter is most likely also influenced during a relapse. To explore the migration of $B$ cell subsets during remission and active disease it is mandatory to measure B cell differentiation profiles simultaneously in different compartments, including secondary lymphoid organs, peripheral blood, and the CNS. 


\section{CHAPTER 4}

Our data revealing a decreased percentage of Bregs in RRMS patients confirmed previous findings on the IL-10 secretion by B cells [8]. Like Hirotani et al., we used CpG-DNA, a Toll-like receptor (TLR) 9 agonist, to activate B cells. Therefore, the decreased IL-10 secretion in MS patients might be due to lower TLR9 expression on B cells, reflecting a reduced state of activation and/or a shifted naïve/memory $B$ cell ratio. As already discussed, memory $B$ cells are indeed decreased in the circulation of MS patients, and this is accompanied by a reduced TLR9 expression on circulating B cells (data not shown). Remarkably, in RRMS patients during a relapse, we found a reduction in the proportion of naïve Bregs. Memory and naïve IL-10 producing B cells are thought to have different functions in autoimmune diseases in humans. The naïve IL-10 producing $B$ cell is thought to be important in preventing inflammatory responses in autoimmune diseases, whereas memory IL-10 producing B cells may function primarily in resolving active disease exacerbations [15]. Our observed shift in naïve/memory ratio within the Bregs in favor of the memory Bregs is in line with this hypothesis. Furthermore, the findings that in vitro interferon beta treatment was shown to induce IL-10 secretion by $B$ cells [26], in combination with an increase in naïve B cells, strengthen the hypothesis that interferon beta reduces the relapse rate in MS patients via manipulation of the $B$ cell compartment.

Although we used CpG DNA, other stimulation protocols can also be used to measure IL-10 secretion by B cells. After CD40 stimulation Duddy et al. showed that IL-10 was almost exclusively produced by naïve B cells [27]. Also T cells can induce Bregs through cognate CD40/CD40 ligand interaction. The induced Bregs in turn, are able to modulate $T$ cell responses, and in particular Tregs [28]. Interestingly, CD40 ligation of naïve $B$ cells from treatment naïve RRMS patients resulted in a significant increase in IL-10 production as compared to naïve B cells from healthy donors [29]. This suggests that there is no intrinsic defect in naïve B cells to produce IL-10 in RRMS patients, which suggests that the reduced IL-10 production in B cells could be caused by defective crosstalk between B cells and other leukocytes. This is further supported by the finding that during remission, an increased percentage of naïve B cells was found while this did not result in an increase in the proportion of IL-10 producing B cells.

We found no correlation between vitamin D status and the proportion of B cell subsets including Bregs, in $\mathrm{HC}$ and in RRMS patients. Vitamin D affects $B$ cells in vitro. Exposure of stimulated $B$ cells ( $C D 40$ and $B C R$ ligation) to $1,25(\mathrm{OH})_{2} \mathrm{D}$ reduced isotype switch and immunoglobulin synthesis, while promoting CD38 expression [30]. Interestingly, it was shown that exposure to $1,25(\mathrm{OH})_{2} \mathrm{D}$ in vitro induces IL-10 production in $\mathrm{B}$ cells [14]. However, high dose vitamin D supplementation in RRMS patients did not affect differentiation profile of circulating $B$ cells as measured directly ex vivo [31]. Accordingly, we find now no correlation between $B$ cell differentiation and vitamin $D$ status within the physiological range. In addition, our results do not support an in vivo interaction between vitamin D on the fraction of IL-10 producing B cells, albeit that the 
effect of supplementation is not known. Hypothetically, vitamin D might affect the function instead of the proportion of Bregs in vivo, like we previously observed for the Treg [13]. Alternatively, interactions between vitamin D3 and B cell subsets could be restricted to sites of $B$ cell activation in MS, that is, the CNS. Although Holmoy et al. could not establish a significant correlation between 25(OH)D level in CSF and CSF IgG index [32], a significant negative correlation has been shown between peripheral plasma 25(OH)D levels and CSF IgG index [33]. Since we measured B cell subsets in peripheral blood, we cannot confirm this.

This study has several limitations. Experiments were performed on PBMC instead of purified B cells. Therefore, outcomes can be due to interplay between several immune cells as is the case in vivo. Clearly, a consensus for a Breg stimulation protocol and the read out measure is lacking. We used an intracellular IL-10 staining to define Bregs, whereas others measured IL-10 with ELISA on sorted B cells $[8,27]$. These factors make it hard to compare results between the different studies on Bregs. Secondly, the majority of the MS cohort is treated with interferon beta, compared to none of the control subjects. Although we did not observe any difference between RRMS patients treated vs. not treated with interferon beta, the effect of interferon beta in vivo on Bregs is not known. Lastly, the included RRMS population is not completely representative for the expected vitamin D status. In our study, the vitamin $D$ status is higher in the MS cohort when compared to the healthy control cohort. This is due to the inclusion of RRMS patients that were, prior to inclusion, supplemented with high doses of vitamin D [16].

Altogether, our results further describe B cell subsets, and in particular Bregs, in MS during resting and active disease. Bregs are significantly reduced in MS and during a relapse there is a shift in the naive/memory ratio within the Bregs. We could not find an association between the vitamin $D$ status and the proportion of Bregs. Future studies should elucidate the functions of $B$ cells and the cross talk between $B$ cells and other leukocytes, in particular during a relapse. Overall, a better understanding of $B$ cell cross talk with other leukocytes will be helpful in developing therapies to modulate both regulatory $B$ cells and regulatory $T$ cells for controlling autoimmunity. 


\section{CHAPTER 4}

\section{References}

1. Compston, A. and A. Coles, Multiple sclerosis. Lancet, 2008. 372(9648): p. 1502-17.

2. Bar-Or, A., et al., Rituximab in relapsing-remitting multiple sclerosis: a 72-week, open-label, phase I trial. Ann Neurol, 2008. 63(3): p. 395-400.

3. van de Veerdonk, F.L., et al., The anti-CD20 antibody rituximab reduces the Th17 cell response. Arthritis Rheum, 2011. 63(6): p. 1507-16.

4. Duddy, M., et al., Distinct effector cytokine profiles of memory and naive human B cell subsets and implication in multiple sclerosis. J Immunol, 2007. 178(10): p. 6092-9.

5. Fillatreau, S., et al., B cells regulate autoimmunity by provision of IL-10. Nat Immunol, 2002. 3(10): p. 944-50.

6. Blair, P.A., et al., CD19( $\left.{ }^{+}\right) \mathrm{CD} 24($ hi)CD38(hi) B cells exhibit regulatory capacity in healthy individuals but are functionally impaired in systemic Lupus Erythematosus patients. Immunity, 2010. 32(1): p. 129-40.

7. Bouaziz, J.D., et al., IL-10 produced by activated human B cells regulates CD4( $\left.{ }^{+}\right)$T-cell activation in vitro. Eur J Immunol, 2010. 40(10): p. 2686-91.

8. Hirotani, M., et al., Decreased IL-10 production mediated by Toll-like receptor 9 in B cells in multiple sclerosis. J Neuroimmunol, 2010. 221(1-2): p. 95-100.

9. Smolders, J., et al., Association of vitamin D metabolite levels with relapse rate and disability in multiple sclerosis. Mult Scler, 2008. 14(9): p. 1220-4.

10. van der Mei, I.A., et al., Vitamin D levels in people with multiple sclerosis and community controls in Tasmania, Australia. J Neurol, 2007. 254(5): p. 581-90.

11. Nashold, F.E., et al., Rag-1-dependent cells are necessary for 1,25-dihydroxyvitamin $D(3)$ prevention of experimental autoimmune encephalomyelitis. J Neuroimmunol, 2001. 119(1): p. 16-29.

12. Spach, K.M., et al., IL-10 signaling is essential for 1,25-dihydroxyvitamin D3-mediated inhibition of experimental autoimmune encephalomyelitis. J Immunol, 2006. 177(9): p. 6030-7.

13. Smolders, J., et al., Vitamin D status is positively correlated with regulatory $T$ cell function in patients with multiple sclerosis. PLoS One, 2009. 4(8): p. e6635.

14. Heine, G., et al., 1,25-dihydroxyvitamin $\mathrm{D}(3)$ promotes IL-10 production in human B cells. Eur J Immunol, 2008. 38(8): p. 2210-8.

15. Rieger, A. and A. Bar-Or, B-cell-derived interleukin-10 in autoimmune disease: regulating the regulators. Nat Rev Immunol, 2008. 8(6): p. 486-7.

16. Smolders, J., et al., Safety and T cell modulating effects of high dose vitamin D3 supplementation in multiple sclerosis. PLoS One, 2010. 5(12): p. e15235.

17. Agematsu, K., et al., CD27: a memory B-cell marker. Immunol Today, 2000. 21(5): p. 204-6.

18. Pascual, V., et al., Analysis of somatic mutation in five B cell subsets of human tonsil. J Exp Med, 1994. 180(1): p. 329-39.

19. Luning Prak, E.T., et al., Age-related trends in pediatric B-cell subsets. Pediatr Dev Pathol, 2011. 14(1): p. 45-52.

20. Lee-Chang, C., et al., B-cell subsets up-regulate alpha4 integrin and accumulate in the cerebrospinal fluid in clinically isolated syndrome suggestive of multiple sclerosis onset. Neurosci Lett, 2011. 487(3): p. 273-7.

21. Cepok, S., et al., Short-lived plasma blasts are the main B cell effector subset during the course of multiple sclerosis. Brain, 2005. 128(Pt 7): p. 1667-76.

22. Corcione, A., et al., Recapitulation of $B$ cell differentiation in the central nervous system of patients with multiple sclerosis. Proc Natl Acad Sci U S A, 2004. 101(30): p. 11064-9.

23. Krumbholz, M., et al., Natalizumab disproportionately increases circulating pre-B and B cells in multiple sclerosis. Neurology, 2008. 71(17): p. 1350-4 
24. Putzki, N., et al., Effects of natalizumab on circulating B cells, T regulatory cells and natural killer cells. Eur Neurol, 2010. 63(5): p. 311-7.

25. Niino, M., et al., Memory and naive B-cell subsets in patients with multiple sclerosis. Neurosci Lett, 2009. 464(1): p. 74-8.

26. Ramgolam, V.S., et al., B Cells as a Therapeutic Target for IFN-\{beta $\}$ in Relapsing-Remitting Multiple Sclerosis. J Immunol, 2011. 186(7): p. 4518-26.

27. Duddy, M.E., A. Alter, and A. Bar-Or, Distinct profiles of human B cell effector cytokines: a role in immune regulation? J Immunol, 2004. 172(6): p. 3422-7.

28. Lemoine, S., et al., Human $T$ cells induce their own regulation through activation of $B$ cells. J Autoimmun, 2011. 36(3-4): p. 228-38.

29. Harp, C.T., et al., Memory B cells from a subset of treatment-naive relapsing-remitting multiple sclerosis patients elicit CD4( $\left(^{+}\right)$T-cell proliferation and IFN-gamma production in response to myelin basic protein and myelin oligodendrocyte glycoprotein. Eur J Immunol, 2010. 40(10): p. 2942-56.

30. Chen, S., et al., Modulatory effects of 1,25-dihydroxyvitamin D3 on human B cell differentiation. J Immunol, 2007. 179(3): p. 1634-47.

31. Knippenberg, S., et al., Effect of vitamin D3supplementation on peripheral B cell differentiation and isotype switching in patients with multiple sclerosis. Mult Scler, 2011.

32. Holmoy, T., et al., Intrathecal levels of vitamin D and IgG in multiple sclerosis. Acta Neurol Scand, 2011.

33. Vogt, M.H., et al., Increased osteopontin plasma levels in multiple sclerosis patients correlate with bone-specific markers. Mult Scler, 2010. 16(4): p. 443-9. 



\section{Chapter 5}

\section{Role of vitamin D in multiple sclerosis: implications for disease management}




\section{CHAPTER 5}

\section{Abstract}

This review discusses the evidence on the role of vitamin $D$ in multiple sclerosis (MS) and whether vitamin D supplementation is effective for the management of MS. People with MS are at high risk of vitamin D deficiency, osteoporosis and fractures. Observational data suggest that higher vitamin $D$ levels are associated with lower relapse risk and there is promising evidence on its effect on MRI measures, disability progression, mental health and fatigue. However, there is currently insufficient randomized controlled trial evidence to recommend vitamin $D$ supplementation with the aim to improve those outcomes. There is sufficient evidence to justify assessing and correcting vitamin D and calcium levels to optimize bone health in people with MS at high absolute risk of fracture. 


\section{Multiple sclerosis background}

Multiple sclerosis (MS) is characterized by a complex interplay between inflammatory and neurodegenerative processes in the CNS, resulting in inflammatory demyelination and neurological dysfunction [1]. There are currently five classes of therapy that have generated good Phase III clinical trial data to support their use in preventing relapses in relapsing remitting MS (RRMS): IFN- $\beta$, glatiramer acetate, natalizumab, fingolimod and cladribine [2]. There are also a number of other treatments in various stages of Phase III study including alemtuzumab, daclizumab, laquinimod, dimethyl fumarate and teriflunomide [3]. Neurologists are now able to treat RRMS, with significant reductions in relapse rates, delayed progression to clinically-definite MS after a first demyelinating event and significant decreases in MRI-detected disease activity [2]. Less evidence is available on the prevention or slowing of the disability progression. Also, there are no approved treatments available for primary or secondary progressive MS. Importantly, available medications are all expensive and consequently, not available to all people with MS who meet treatment criteria. An increasing volume of epidemiological research is supportive of a role for vitamin D as a therapeutic agent for MS, either standalone or in combination with other immunomodulatory medications $[4,5]$. By contrast to current firstline treatment regimens [2], vitamin D-based therapies seem to have little side effects or risk of toxicity, although future large randomized controlled trials (RCTs) need to confirm this, particularly when high-dose treatments are being used. Herein the physiology and immunological effects of vitamin $D$, the epidemiologic evidence supporting its role in MS onset and clinical course, such as relapses, MRI measures, progression in clinical disability, depression, anxiety, fatigue, cognitive function, bone health, acute infection, herpes virus reactivation and smoking, and the work-in-progress elucidating its utility as an add-on therapy in MS will be discussed.

\section{Metabolism of vitamin D}

There are two major forms of vitamin D, cholecalciferol (vitamin D3) and ergocalciferol (vitamin D2). The majority of vitamin D3 is produced by photolysis of precursor cholesterol in the keratinocytes in the skin; there are few dietary sources of vitamin D3, with oily fish being the most important naturally occurring source [6]. Vitamin D2 is derived solely from dietary sources, particularly UV-irradiated mushrooms. Both types of vitamin $D$ can also be obtained in dietary supplements. Vitamin $D$ is bound by vitamin $D$ binding protein (VDBP) and may be stored in adipocytes or transported to the liver for primary hydroxylation to the major circulating form, 25-hydroxyvitamin $D$ (25[OH]D) $[4,7] .25(\mathrm{OH}) \mathrm{D}$ can be stored within hepatocytes or bound to VDBP for transport in serum to the kidney for secondary hydroxylation to the active form, 1,25dihydroxyvitamin $\mathrm{D}(1,25[\mathrm{OH}] 2 \mathrm{D})$. This nephritic production of $1,25[\mathrm{OH}] 2 \mathrm{D}$ is principal- 


\section{CHAPTER 5}

ly for use in bone metabolism and calcium homeostasis and is tightly regulated by feedback of calcium phosphate and parathyroid hormone, as well as negative feedback from serum $1,25(\mathrm{OH})_{2} \mathrm{D}[4,7]$. There is also a local conversion of $25(\mathrm{OH}) \mathrm{D}$ to the active form in a variety of cell and tissue types, including immune cells and glial cells of the CNS [4]. This conversion is not regulated by the same feedback controls as nephritic conversion, with enzyme expression and function being regulated by microenvironmental conditions and cytokines [4]. Diagnostic assay of vitamin D status is carried out by measuring serum $25(\mathrm{OH}) \mathrm{D}$ rather than $1,25(\mathrm{OH})_{2} \mathrm{D}$ [4], because the half-life of $25(\mathrm{OH}) \mathrm{D}$ is longer ( $2-3$ months) [8] and $1,25(\mathrm{OH})_{2} \mathrm{D}$ is more tightly regulated by serum calcium, parathyroid hormone and negative feedback mechanisms.

\section{Immunomodulatory effects of vitamin D}

In the periphery

The effects of vitamin $D$ on the immune system have been reviewed in detail elsewhere $[9,10] .1,25(\mathrm{OH})_{2} \mathrm{D}$ has been demonstrated in vitro to depress proinflammatory immune cell activity $[4,7,11,12]$, as well as inducing apoptosis in activated inflammatory cells $[4,12]$, while simultaneously stimulating Th2 and Treg proliferation and function $[4,13,14]$. In addition to its effects on T cells, vitamin D affects multiple aspects of the immune system, including modulating elements of the innate immune system to stimulate the production of antimicrobial peptides $[15,16]$, as well as playing a key regulatory role over the maturation and activation of antigen-presenting dendritic cells, representing an important check on the initiation of adaptive immune response $[9,16]$.

\section{Within the CNS}

The effects of vitamin D on the CNS has been nicely reviewed by Smolders and colleagues [17]. While the vitamin $D$ receptor (VDR) and vitamin $D$ hydroxylase enzymes are found in both neurons and glial cells [18], no data are available on $1,25(\mathrm{OH})_{2} \mathrm{D}$ in cerebrospinal fluid or in the CNS. In the periphery, $1,25(\mathrm{OH})_{2} \mathrm{D}$ levels are 100-1000times lower than 25(OH)D levels and since cerebrospinal fluid 25(OH)D concentrations are $<1 \%$ that of serum, $1,25(\mathrm{OH})_{2} \mathrm{D}$ concentrations can be assumed to be low [19]. However, interesting data suggests that $1,25(\mathrm{OH})_{2} \mathrm{D}$ influences cytokine release and antigen presentation in the CNS. For example, exposure of lymphocytes in the CNS to $1,25(\mathrm{OH})_{2} \mathrm{D}$ seems to shift the cytokine profile towards anti-inflammatory cytokines [20] and a reduction of the production of proinflammatory cytokines and nitric oxide by microglia has been observed [21]. Also, similar to the periphery, antigen presentation is reduced after $1,25(\mathrm{OH})_{2} \mathrm{D}$ exposure [22] and a reduced MHC class II immunoreactivity in the CNS is also observed after systemic treatment with $1,25(\mathrm{OH})_{2} \mathrm{D}$ in rats [23]. Vitamin $D$ also plays a role in brain development [24,25] and remyelination [26]. 


\section{Vitamin D levels in people with MS}

Studies comparing serum $25(\mathrm{OH}) \mathrm{D}$ in people with MS with healthy controls generally find lower levels in people with MS [27-31]. Differences are not always observed, but this might be due to bias because it occurs in small samples or studies where cases and controls are not population based [32,33]. In a population-based case-control study of prevalent MS cases (latitude $42^{\circ} \mathrm{S}$ )[27], we found a high level of vitamin D deficiency $(50.7 \% \leq 50 \mathrm{nmol} / \mathrm{I})$. In line with other studies, increasing disability was strongly associated with lower 25(OH)D $(r=-0.55 ; p<0.001)[34,35]$. Indeed, cases with higher disability (Expanded Disability Status Scale [EDSS] >3) were threetimes more likely to be vitamin D-deficient than controls (odds ratio [OR]: $3.07 ; 95 \% \mathrm{Cl}: 1.37-6.90$ ), but cases with lower disability were not (OR: $0.87 ; 95 \% \mathrm{Cl}: 0.41-1.86)$ [27]. We also found that higher EDSS was associated with reduced sun exposure $(r=-0.39 ; p<0.001)$. Nearly half of the excess risk of low vitamin $D$ among people with a higher disability compared with controls was statistically attributable to lower sun exposure [27], suggesting that low sun exposure is part of the reason why those with a higher disability have lower vitamin D levels. Levels of $1,25(\mathrm{OH})_{2} \mathrm{D}$ were also lower in people with MS compared with controls in one study [31]. This was not observed in two other studies [32,33], the same two studies that also observed no difference in $25(\mathrm{OH}) \mathrm{D}$ levels.

\section{Vitamin D \& MS risk}

It has long been recognized that MS frequency is generally positively-associated with latitude [36,37] and a recent meta-analysis clearly shows this latitudinal gradient [38]. The gradient is also seen in relatively ethnically-homogeneous populations [39-41], suggesting the involvement of environmental determinants, particularly exposure to UV radiation (UVR). There is now substantial epidemiological evidence that high personal UV exposure and circulating $25(\mathrm{OH}) \mathrm{D}$ is associated with a reduced MS risk, including case-control studies and prospective cohort studies [42-45]. For example, a nested case-control study, which measured 25(OH)D levels prior to disease-onset, showed that higher 25(OH)D levels were associated with a lower MS risk (OR: 0.59; [95\% Cl: 0.36-0.97] per $50 \mathrm{nmol} / \mathrm{l}$ increase) [42]. A substantial number of studies have examined the role of personal sun exposure and MS onset [46]. Although no prospective cohort studies have reported on sun exposure and MS, other observational studies are consistent in identifying associations between different sun measures or vitamin D and MS onset or mortality [45,47-51]. We recently examined the relative importance of both $25(\mathrm{OH}) \mathrm{D}$ and UV exposure in an incident case-control study of first demyelinating events and found that both $25(\mathrm{OH}) \mathrm{D}$ levels and exposure to UV were independent predictors of onset [44]. This is in line with the evidence provided in a recent review from Hart and colleagues [10]. The importance of 25(OH)D 


\section{CHAPTER 5}

or UV exposure seems not to be limited to one phase of life. While some studies show that childhood/ adolescence might be particularly important $[45,47,48]$, other studies find that cumulative (e.g., skin cancer) [52] and adult-life (e.g., occupational) [50,51] exposures are important as well. Moreover, some studies suggest that exposure in utero is important, with more MS people born in spring (and thus, having foetal gestation in winter) than in autumn $[53,54]$ and in one study the association was abrogated on adjustment for ambient UVR in the first trimester, suggesting that exposure to UVR is the primary mediator of the season of birth effect [54]. Being born in winter and having a birthplace with low solar radiation $[55,56]$ has also been associated with an earlier age of disease onset, whereas greater vitamin $D$ intake was associated with a later age of disease onset [56]. The above epidemiological data is in line with data from animal models of MS, experimental autoimmune encephalitis (EAE), because treatment of mice with $1,25(\mathrm{OH})_{2} \mathrm{D}$ or UV has been found to prevent EAE onset when given prior to induction [23,57-59]. Importantly, treating mice who developed EAE with $1,25(\mathrm{OH})_{2} \mathrm{D}$ improves the progression of EAE or wholly reverses the disease $[23,57,58]$. If the same holds true for humans, then vitamin $D$ could be a powerful and cheap therapeutic option that limits the progression of the disease.

\section{Vitamin D \& MS clinical course}

Vitamin D may influence a number of aspects of clinical course, including relapses, MRI measures, progression in clinical disability, depression, anxiety, fatigue, cognitive function, bone health, acute infection, herpes virus reactivation and smoking.

\section{Relapses}

Ecological and observational data show that higher levels of 25(OH)D are associated with a reduced relapse risk. Seasonality in relapses has been observed in people with MS and the monthly relapse rate correlated inversely with ambient UV $(r=-0.32$, lagged by 1.5 months) and monthly 25(OH)D levels ( $r=-0.31$, no lag) [60]. Studies comparing 25(OH)D levels between relapse and remission samples found lower levels during relapses $[31,61,62]$, but it is uncertain whether this is due to reverse causality. In a retrospective study, 25(OH)D levels were associated with the risk of remaining relapse-free in the previous 2 years $(p=0.017)$, but not with relapse rate in that period [34]. Importantly, two prospective cohort studies have demonstrated an inverse association between $25(\mathrm{OH}) \mathrm{D}$ and relapse risk, suggesting this association might be causal: we prospectively followed a cohort of 145 RRMS patients for a mean of 2.3 years, finding a $12 \%$ reduction in the hazard of relapse per $10 \mathrm{nmol} / \mathrm{l}$ increase in serum $25(\mathrm{OH}) \mathrm{D}$ [63]. Similarly, Mowry and colleagues found a $44 \%$ reduction in relapse risk per 25 $\mathrm{nmol} / \mathrm{l}$ increase in 25(OH)D in a cohort of 110 paediatric-onset MS cases [64]. Few studies have examined the association between $1,25(\mathrm{OH})_{2} \mathrm{D}$ and relapses. Correale and 
colleagues found lower levels during relapse compared with remission [31], although in a different study this was only observed in women [65]. Smolders and colleagues did not find an association between $1,25(\mathrm{OH})_{2} \mathrm{D}$ and relapse in the previous 2 years [34].

\section{Progression in clinical disability}

We noted that lower 25(OH)D levels were associated with a higher disability, but that this might reflect less sun exposure. Whether low 25(OH)D levels result in a faster progression of clinical disability is a different question. Crosssectionally, this can be examined using disability as an outcome and taking disease duration into account. The MS Severity Scale (MSSS) has been designed to do exactly that [66]. Recently, Weinstock-Guttman and colleagues showed that both lower 25(OH)D $(p=0.029)$ as well as 24,25 -dihydroxyvitamin $\mathrm{D} 3\left(24,25[\mathrm{OH}]_{2} \mathrm{D} 3\right.$, breakdown product of $\left.25[\mathrm{OH}] \mathrm{D}\right)$ and $\left.1,25[\mathrm{OH}]_{2} \mathrm{D}\right)$ were associated with a higher MSSS score $(p=0.005)$ [35]. Another study evaluating an African-American population with MS found no association between 25(OH)D, unadjusted or deseasonalized, with either MSSS or EDSS [30], which the authors suggest may be due to the darker skin of African-Americans relative to the majority Caucasian (91.7\%) population used in the Weinstock-Guttman study [35]. In order for causality to be ascertained, prospective analyses evaluating the change in disability over time are required; however none have been published.

\section{MRI measures}

Auer and colleagues [67] reported that gadolinium-enhancing MRI lesions showed a seasonal variation. Embry and colleagues [68] subsequently compared this seasonal variation in MRI lesions with the distribution of serum 25(OH)D over time in a representative sample of healthy German adults (lagged by 2 months), finding the change in 25(OH)D was significantly correlated with the seasonal change in lesion number. However, Weinstock-Guttman and colleagues found no association between 25(OH)D, $1,25(\mathrm{OH})_{2} \mathrm{D}$ or $24,25(\mathrm{OH})_{2} \mathrm{D}$ and $\mathrm{T} 2$ lesion volume, $\mathrm{T} 1$ lesion volume or brain parenchymal fraction, although they did find that a higher ratio of $25(\mathrm{OH}) \mathrm{D}$ to $24,25(\mathrm{OH})_{2} \mathrm{D}$ was associated with a lower brain parenchymal fraction $(p=0.004)$ [35]. Other studies found no associations between 25(OH)D levels and MRI-assessed disease activity $[19,61,62]$.

\section{RCT evidence}

While observational studies have demonstrated an association between $25(\mathrm{OH}) \mathrm{D}$ levels and relapses, RCTs are needed to demonstrate whether vitamin D supplementation reduces relapses. Table 1 shows the trials on vitamin $D$ and MS: all trials are small and focus generally on the tolerability of high-dose cholecalciferol [69-71] or calcitriol [72]. Early trials showed effects on relapse and EDSS; however these studies were neither blinded nor placebo controlled and the effects could have been due to other components of the treatment $[73,74]$. One Phase I/II RCT by Burton and colleagues [70] eval- 


\section{CHAPTER 5}

uated the relationship between vitamin D supplementation and clinical outcomes, including annual relapse rate and disability as measured by EDSS, finding reductions in both among persons in the vitamin D-treated group $(n=25)$ relative to controls $(n=$ 24). This study does have some limitations, as it was primarily designed to evaluate the safety and tolerability of vitamin D supplementation: this was a small cohort $(n=49)$, controls were allowed to take variable amounts of vitamin $\mathrm{D}$ supplementation up to $4000 \mathrm{IU} /$ day and clinical follow-up was focused on the treatment group, with controls only evaluated at baseline and study conclusion. With these limitations in mind, the results should be interpreted with caution; however these results are encouraging and larger cohort RCTs are indicated. Only one RCT has been conducted with disease progression as an outcome [75]. In this trial of 62 IFN- $\beta$ - 1 a treated patients, 300,000 IU (n $=28)$ or placebo $(n=34)$ was administered intramuscularly at one dose per month. After 6 months, no differences in the change of EDSS or gadolinium-enhancing lesions were observed compared with placebo, although this may have been a consequence of sample size and the short follow-up. This study did, however, find immunological changes (increased TGF-b and IL-10 [p < 0.001]), this in line with other studies [71,76], suggesting a possible immunomodulatory effect of vitamin $D$ therapy even over this short time period. In light of the strong observational cohort evidence alongside a relative paucity of RCT evidence, high-quality and well-powered vitamin D supplementation RCTs are needed to prove efficacy in terms of relapses, clinical disability and MRI measures. The most efficacious dose need to be determined and long-term safety need to be demonstrated if moderate to high dose supplementation were to be most efficacious. RCTs along these lines are presently underway. For example, the European SOLAR trial $(n=348)$ is a 96-week Phase II trial that aims to evaluate the efficacy of high-dose cholecalciferol (14,000 IU/day) as an add-on therapy to IFN-b-1a in patients with RRMS $[77,201]$ and a French Phase II trial $(n=200)$ is also an add-on therapy to IFN-b-1a, with 100,000 IU given twice a month versus placebo [202]. In the USA, a randomized double blind trial $(n=172)$ has just started which will evaluate the safety and effectiveness of high-dose cholecalciferol (5000 IU/day) versus low dose (600 IU/day) as an add-on to glatiramer acetate therapy in reducing disease activity [203]. It is important that a range of dosages is tested, preferably within one RCT, because the assumption that 'more is better' might not hold. The fact that clinical practice is already running ahead of the RCT evidence and patients are commonly being treated with some vitamin D (e.g., 1000-2000 IU/day) means that compliance issues arise when using a placebo arm. Indeed, the US trial has already chosen a low-dose arm as the control group.

\section{Mental health symptoms and fatigue}

Depression, fatigue, anxiety and cognitive impairment are common symptoms in MS [78-82]. Although these symptoms can profoundly affect the quality of life, an association with vitamin D status have deserved little attention in current MS research. 
In a retrospective study, low 25(OH)D levels were correlated with depressive symptoms in MS patients, although after adjustment for confounders this association was attenuated [83]. Low 25(OH)D has also been associated with depressive symptoms in healthy adults [84], subjects who were obese [85] or had cardiovascular diseases [86]. Importantly, supplementation with cholecalciferol has been shown to improve depression in subjects who were obese [85] or had seasonal affective disorder [86], suggesting a causal association. This, together with the evidence that antidepressants have similar immune regulating effects as vitamin D [87-90] and that VDRs exist in the amygdala [91], indicates that this association warrants further investigation. Even fewer studies have examined the association between 25(OH)D and fatigue, anxiety and cognitive impairment. No correlation has been found between 25(OH)D level and fatigue in MS patients [83]. This is by contrast to findings in systemic lupus erythermotosus, where supplementation with cholecalciferol had a beneficial effect on fatigue [92,93]. In relation to anxiety, while VDR-deficiency directly led to increased symptoms of anxiety in mice [94], levels of 25(OH)D have not been significantly associated with anxiety in humans $[95,96]$. VDRs have been found in the key areas for cognitive functioning: the human cortex and in the hippocampus [97]. Interestingly, a low 25(OH)D has been associated with a more rapid loss of Mini-Mental Status Examination scores and a poor performance on tests measuring memory and executive functioning in the normal aging population $[98,99]$ and in patients with Alzheimer's disease [100]. Whether an association between 25(OH)D and cognitive function also exists in MS patients has not yet been investigated. For epidemiological studies assessing the association between 25(OH)D and these outcomes, reverse causality is a concern, because individuals with these symptoms may be less likely to go outside, thus, have less exposure to the sun and thus lower 25(OH)D levels. Therefore, it is recommended that mental health symptoms and fatigue are measured in future vitamin D supplementation trials in people with MS.

\section{Bone health}

The key issue for bone health is fracture prevention, since this causes greatest morbidity, mortality and health costs. Fractures are common in people with MS [101] and the risk is higher compared with healthy controls [102]. In a large population-based cohort using a data linkage approach, hip fracture risk was nearly three-times the hazard ratio (HR): $2.79 ; 95 \% \mathrm{Cl}: 1.83-4.26)$ that in controls and the overall osteoporotic fracturerisk was increased 1.4-fold (HR: 1.3; 95\% Cl: 1.13-1.62) [103]. There are multiple risk factors contributing to the increased risk of fracture in MS but these are yet to be fully elucidated. While people with MS are in general at higher risk, their absolute risk of fracture risk increases with age, being low in younger people and becoming substantial after about the age of 60 years [103]. Other major risk factors include glucocorticoid use [103], antidepressants [103] and level of disability [104]. Other major potential contributors or mediators of high risk are reduced bone density and osteoporosis (as 


\section{CHAPTER 5}

reviewed by Hearn and Silber [105]) and a high risk of falling [106-109]. Bone mineral density (BMD) is lower and self-reported tendency to fall is higher even in newlydiagnosed clinically isolated syndrome and MS, though fractures are not increased in that group $[110,111]$. This suggests that there could be shared etiological factors or pathogenic mechanisms in MS and osteoporosis [111] and possibly in falls, for example, low vitamin D levels [110]. Indeed, low serum vitamin $D$ is a factor implicated in osteoporotic fractures, low BMD and in falls in the elderly [112], as well as being common in patients with MS. Despite emerging evidence of the deleterious effects of MS on bone health, currently there are no accepted MS specific guidelines for the prevention and management of osteoporosis and osteoporotic fracture in MS. Two approaches have been put forward. MS could be considered a cause of secondary osteoporosis (comparable with rheumatoid arthritis) and attending to bone health should therefore be integrated into overall MS care according to existing guidelines [113]. An alternative position is that people with MS at risk of deficiency should have their vitamin $D$ and calcium intake assessed and supplemented if needed and that postmenopausal women with MS and all other patients with an EDSS score $\geq 6.0$ should receive a dual energy $x$-ray absorptiometry scan to screen for low BMD [105]. Treatment should then proceed according to accepted guidelines. The latter is based on evidence suggesting that the degree of disability and reduced mobility is a major risk factor for osteoporosis in patients with MS [105]. Regardless of the exact approach, it is clear that optimizing bone health should be integrated into the care of people with MS. The role of vitamin $\mathrm{D}$ in the prevention and management of osteoporosis in postmenopausal women is well-established. A patient-level data meta-analysis of seven major RCTs including over 68,000 participants [114] demonstrated that vitamin D with calcium reduced overall fracture risk (HR: $0.92 ; 95 \% \mathrm{Cl}: 0.86-0.99)$ and hip fracture if a sufficient dose of vitamin D (400 IU/day) was given with calcium (HR: $0.74 ; 95 \% \mathrm{Cl}$ : $0.60-$ 0.91). However, vitamin $D$ alone (400-800 IU/day) did not protect against fracture so an adequate calcium intake from either dietary sources or by supplementation also needs to be ensured. Another meta-analysis demonstrated that slightly higher doses (700- $1000 \mathrm{IU} /$ day) were needed to reduce the risk of falls [115]. In healthy younger women, the current evidence is insufficient to support the use of vitamin D supplements to improve bone health [116]. For people with MS, there is only a single, small placebo-controlled RCT of vitamin D supplements in young patients (aged 18-50 years) (Table 1) examining bone outcomes [117]. Participants received either 20,000 IU Vitamin D3 or placebo once a week with $500 \mathrm{mg}$ calcium daily for 96 weeks. They observed a slower decrease in BMD in the treatment group (0.7\%) compared with the control group $(1.4 \%)$, but this difference was not significant $(p=0.332)$, probably partly because of the limited sample size and power. Larger trials in MS patients are warranted, preferably including falls and fractures as outcomes. Until sufficient evidence becomes available, however, the role of vitamin D supplements to improve bone outcomes in young MS patients remains unclear. The available evidence suggests that assessing and 
managing vitamin $D$ status should be an integral part of managing bone health in patients with MS, including assessing serum vitamin D levels in people at high risk of fracture, which already applies to anyone with one or more risk factors putting them at high risk of osteoporotic fracture. Other potential beneficial effects of vitamin D \& interactions with other risk factors Vitamin D might also influence other factors that are associated with MS clinical course or patient wellbeing, including acute infection and herpesvirus reactivation. Smoking cessation might also improve the clinical course and modulate vitamin D metabolites.

\section{Acute infection}

In 1985, Sibley and colleagues demonstrated an association between acute infections, particularly upper respiratory tract infections and relapses in MS patients [118]; however a causal pathway has never been demonstrated. More recently, lower levels of serum 25(OH)D have been associated with symptomatic acute infections [119] and work on tissue cultures shows that vitamin $D$ plays a role in the innate immune system $[120,121]$. There is some evidence from RCTs that vitamin D supplementation reduces the occurrence of symptomatic acute infections [122] and influenza [123]. It may be then that vitamin $D$ attenuates the overt immune response against respiratory tract infections such that infections are not clinically apparent. Alternatively, vitamin D's stimulation of antimicrobial peptides acting against the rhinoviruses which cause many respiratory tract infections [124] may allow for more rapid clearance of pathogens before overt symptoms are initiated and low $25(\mathrm{OH}) \mathrm{D}$ may preclude this rapid clearance, yielding more symptomatic presentation. Given the absence of a biologically plausible etiologic association between the pathogens involved in acute infections and CNS pathology, it may be that symptomatic acute infection and relapse are separate outcomes of low vitamin D.

\section{Herpesvirus reactivation}

It is biologically conceivable that vitamin D and Epstein-Barr virus (EBV) or human herpesvirus 6 interact to manifest in MS $[125,126]$. Hypotheses along these lines have been proposed, Hayes and Acheson proposing that the EBV produced analog of IL-10 might interact with low vitamin $D$ conditions to manifest in increased immune dysregulation [127], leading to exacerbations. Hølmoy proposed that reactivation of EBV coinciding with periods of low vitamin $D$ interact to increase exacerbation risk [128]. It is plausible for either or both of these interactions to occur, given the evidence in favor of herpesviruses and vitamin D acting independently in MS causation.

\section{Smoking}

Tobacco smoking and passive tobacco smoke exposure have been associated with MS onset [129] and clinical course $[130,131]$. Hernán and colleagues found a significantly greater risk of progression to secondary progressive MS amongst those who smoked 


\section{CHAPTER 5}

(HR: 3.6; 95\% Cl: 1.3-9.9) [130]. We found that cumulative packyears smoked after study entry was associated with an increase in MSSS, measured longitudinally with repeated measures $(p<0.001)$, while no association was observed with relapses [131]. Smoking also has effects on vitamin D absorption and metabolism [132], with levels of serum vitamin $\mathrm{D}$ metabolites significantly lower in smokers in relation to nonsmokers. Smoking is also recognized for its deleterious effects on bone health [133] partly due to its effects on vitamin $D$ metabolites. Thus, smoking cessation seems of benefit in improving vitamin D metabolism and thence bone health and ameliorating MS.

\section{Conclusion \& future perspective}

There is substantial evidence that $1,25(\mathrm{OH})_{2} \mathrm{D}$ has potent immunomodulatory effects, both in the periphery and in the CNS. In addition, there are abundant observational data demonstrating an association between higher 25(OH)D levels and a reduced risk of relapse and the first small RCTs are promising. The evidence for other outcomes such as clinical progression in disability, MRI outcomes, mental health and fatigue is limited but warrants further investigation. We now need high quality and wellpowered vitamin $D$ supplementation RCTs to prove the efficacy for these different outcomes. The most efficacious dose needs to be determined and longterm safety needs to be demonstrated, particulary if moderate-to-high dose supplementation turns out to be most efficacious. Despite the lack of high-quality RCTs, some clinicians and people with MS are already advocating vitamin $\mathrm{D}$ supplementation, sometimes with high doses (5,000-10,0000 IU/day), as a complementary treatment for MS. We would emphasise that caution needs to be employed, because there is currently no solid evidence to support high-dose supplementation and adverse effects are possible. It is promising that a number of RCTs are now underway and the results of these studies will help inform the use of vitamin $D$ in clinical practice. While there is insufficient evidence to justify vitamin $D$ treatment for the above outcomes, we have demonstrated that people with MS are at a high risk of osteoporosis and/or fractures and there is sufficient evidence to justify managing the bone health in patients with MS. Guidelines specific to people with MS are lacking, but it is advisable to take a similar approach to the primary prevention of osteoporotic fractureas used for postmenopausal women by assessing and if necessary correcting vitamin $\mathrm{D}$ levels and calcium intake as part of optimizing bone health in people with MS at high absolute risk of fracture. Supplementation recommendations vary per country but $600-800 \mathrm{IU} /$ day of cholecalciferol and $1000-1200 \mathrm{mg} /$ day of calcium are commonly being used [204,205]. While there is debate about the definition of deficiency, many reference laboratories have already raised their lower boundary of the normal range of 25(OH)D from $50 \mathrm{nmol} / \mathrm{l}$ to 75 $\mathrm{nmol} / \mathrm{l}[134]$. 25(OH)D levels depend on a combination of factors, including ambient UV, behavioral factors and genetics, but supplementation with more than $1000 \mathrm{IU} /$ day 
will be required to maintain these higher levels in winter in many parts of the world. In general, every $100 \mathrm{IU} /$ day of cholecalciferol increases $25(\mathrm{OH}) \mathrm{D}$ levels by $1.75-2.5$ $\mathrm{nmol} / \mathrm{l}$, with a greater rise when baseline levels are lower $[135,136]$. 


\section{CHAPTER 5}

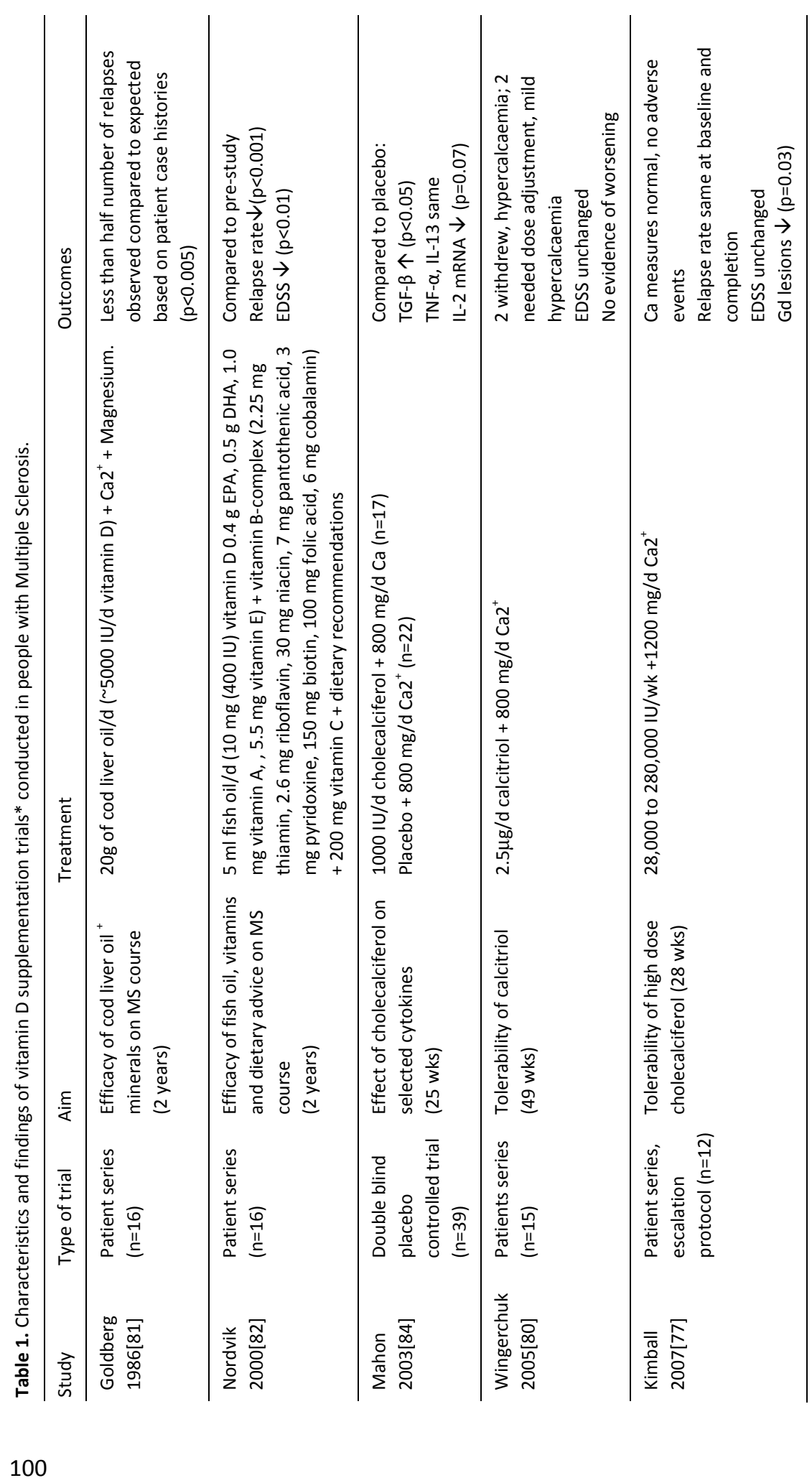


ROLE OF VITAMIN D IN MULTIPLE SCLEROSIS: DISEASE MANAGEMENT

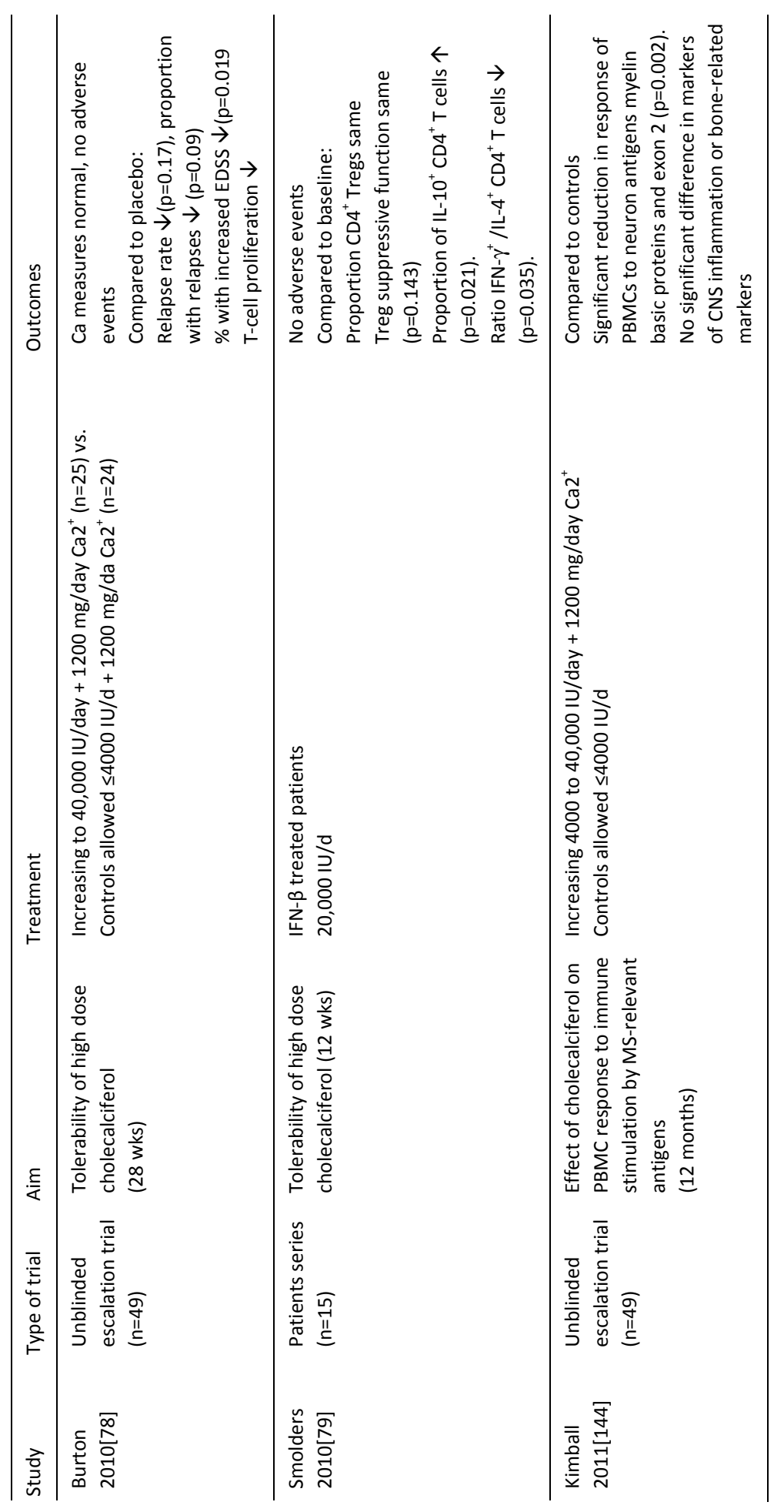


CHAPTER 5

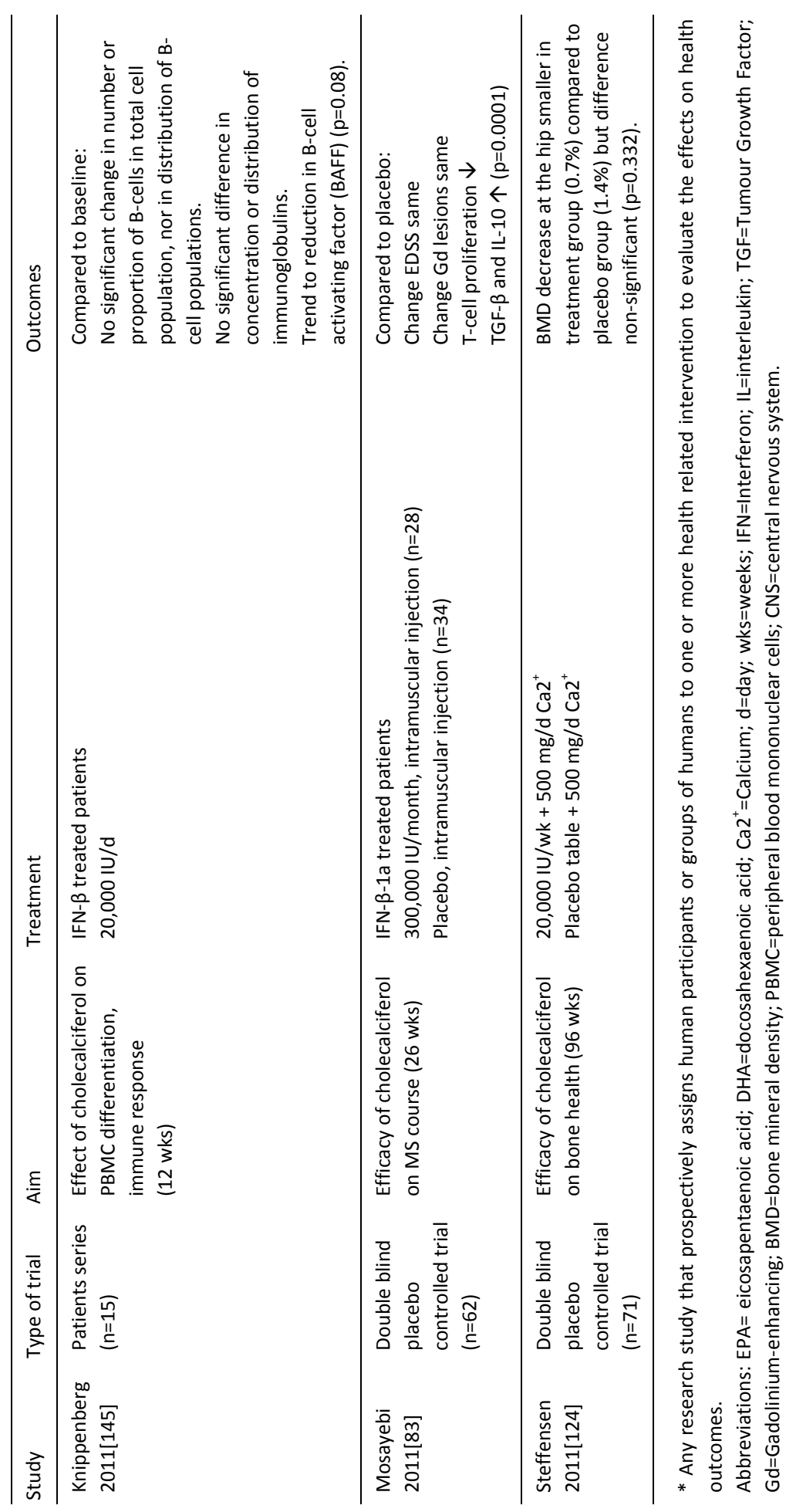

102 


\section{References}

1. Compston A, Coles A. Multiple sclerosis. Lancet 372(9648), 1502-1517 (2008).

2. Derwenskus J. Current disease-modifying treatment of multiple sclerosis. Mt. Sinai J. Med. 78(2), 161175 (2011).

3. Gawronski KM, Rainka MM, Patel MJ, Gengo FM. Treatment options for multiple sclerosis: current and emerging therapies. Pharmacotherapy 30(9), 916-927 (2010).

4. Simpson Jr SL, Greenhill K, van der Mei I, Stankovich J, Charlesworth JC, Taylor B. The varied mechanisms of vitamin $D$ in the onset and clinical course of MS: potential roles in modulating other etiological pathways. Current Medical literature - Neurology 27(1), 1-14 (2011).

5. Niino M, Fukazawa T, Kikuchi S, Sasaki H. Therapeutic potential of vitamin D for multiple sclerosis. Curr. Med. Chem. 15(5), 499-505 (2008).

6. Holick MF. Vitamin D deficiency. N. Engl. J. Med. 357(3), 266-281 (2007).

7. Kamen DL, Tangpricha V. Vitamin D and molecular actions on the immune system: modulation of innate and autoimmunity. J. Mol. Med. 88(5), 441-450 (2010).

8. Vieth R. Vitamin D supplementation, 25-hydroxyvitamin D concentrations, and safety. Am. J. Clin. Nutr. 69(5), 842-856 (1999).

9. Hewison M. Vitamin D and immune function: an overview. Proc. Nutr. Soc. 1-12 (2011).

10. Hart PH, Gorman S, Finlay-Jones JJ. Modulation of the immune system by UV radiation: more than just the effects of vitamin D? Nat. Rev. Immunol. 11(9), 584-596 (2011).

11. Tsoukas CD, Provvedini DM, Manolagas SC. 1,25-dihydroxyvitamin D3: a novel immunoregulatory hormone. Science 224(4656), 1438-1440 (1984).

12. Mora JR, Iwata M, Von Andrian UH. Vitamin effects on the immune system: vitamins $A$ and $D$ take centre stage. Nat. Rev. Immunol. 8(9), 685-698 (2008).

13. Meehan MA, Kerman RH, Lemire JM. 1,25-dihydroxyvitamin D3 enhances the generation of nonspecific suppressor cells while inhibiting the induction of cytotoxic cells in a human MLR. Cell. Immunol. 140(2), 400-409 (1992).

14. Gorman S, Judge MA, Burchell JT, Turner DJ, Hart PH. 1,25-dihydroxyvitamin D(3) enhances the ability of transferred $\mathrm{CD} 4\left(^{+}\right) \mathrm{CD}_{25}\left(^{+}\right)$cells to modulate $\mathrm{T}$ helper type 2-driven asthmatic responses. Immunology 130(2), 181-192 (2010).

15. Bartley J. Vitamin D, innate immunity and upper respiratory tract infection. J. Laryngol. Otol. 124(5), 465-469 (2010).

16. Hewison M. Vitamin D and innate and adaptive immunity. Vitam. Horm. 86, 23-62 (2011).

17. Smolders J, Moen SM, Damoiseaux J, Huitinga I, Holmoy T. Vitamin D in the healthy and inflamed central nervous system. J. Neurol. Sci. doi:10.1016/j.jns.2011.07.033 (2011) (Epub ahead of print).

18. Garcion E, Wion-Barbot N, Montero-Menei CN, Berger F, Wion D. New clues about vitamin D functions in the nervous system. Trends Endocrinol. Metab. 13(3), 100-105 (2002).

19. Hølmoy T, Moen SM, Gundersen TA et al. 25-hydroxyvitamin D in cerebrospinal fluid during relapse and remission of multiple sclerosis. Mult. Scler. 15(11), 1280-1285 (2009).

20. Moore M, Piazza A, Nolan Y, Lynch MA. Treatment with dexamethasone and vitamin D3 attenuates neuroinflammatory age-related changes in rat hippocampus. Synapse 61(10), 851-861 (2007).

21. Lefebvre d'hellencourt C, Montero-Menei CN, Bernard R, Couez D. Vitamin D3 inhibits proinflammatory cytokines and nitric oxide production by the EOC13 microglial cell line. J. Neurosci. Res. 71(4), 575-582 (2003).

22. Penna G, Adorini L. 1 Alpha,25-dihydroxyvitamin D3 inhibits differentiation, maturation, activation, and survival of dendritic cells leading to impaired alloreactive T cell activation. J. Immunol. 164(5), 24052411 (2000). 


\section{CHAPTER 5}

23. Garcion E, Sindji L, Nataf S, Brachet P, Darcy F, Montero-Menei CN. Treatment of experimental autoimmune encephalomyelitis in rat by 1,25-dihydroxyvitamin D3 leads to early effects within the central nervous system. Acta Neuropathol. 105(5), 438-448 (2003).

24. Eyles D, Brown J, Mackay-Sim A, Mcgrath J, Feron F. Vitamin D3 and brain development. Neuroscience 118(3), 641-653 (2003).

25. Eyles DW, Feron F, Cui $X$ et al. Developmental vitamin D deficiency causes abnormal brain development. Psychoneuroendocrinology 34(Suppl. 1), S247-S257 (2009).

26. Goudarzvand M, Javan M, Mirnajafi-Zadeh J, Mozafari S, Tiraihi T. Vitamins E and D3 attenuate demyelination and potentiate remyelination processes of hippocampal formation of rats following local injection of ethidium bromide. Cell. Mol. Neurobiol. 30(2), 289-299 (2010).

27. van der Mei IA, Ponsonby AL, Dwyer T et al. Vitamin D levels in people with multiple sclerosis and community controls in Tasmania, Australia. J. Neurol. 254(5), 581-590 (2007).

28. Shaygannejad V, Golabchi K, Haghighi S, Dehghan H, Moshayedi A. A comparative study of $25(\mathrm{OH})$ Vitamin D serum levels in patients with multiple sclerosis and control group in Isfahan, Iran. Int. J. Prev. Med. 1(3), 195-201 (2010).

29. Ozgocmen S, Bulut S, Ilhan N, Gulkesen A, Ardicoglu O, Ozkan Y. Vitamin D deficiency and reduced bone mineral density in multiple sclerosis: effect of ambulatory status and functional capacity. J. Bone Miner. Metab. 23(4), 309-313 (2005).

30. Gelfand JM, Cree BA, Mcelroy J et al. Vitamin D in African Americans with multiple sclerosis. Neurology 76(21), 1824-1830 (2011).

31. Correale J, Ysrraelit MC, Gaitan MI. Immunomodulatory effects of Vitamin D in multiple sclerosis. Brain 132(Pt 5), 1146-1160 (2009).

32. Kragt J, van Amerongen B, Killestein J et al. Higher levels of 25-hydroxyvitamin D are associated with a lower incidence of multiple sclerosis only in women. Mult. Scler. 15(1),9-15 (2009).

33. Barnes MS, Bonham MP, Robson PJ et al. Assessment of 25-hydroxyvitamin D and 1,25dihydroxyvitamin D3 concentrations in male and female multiple sclerosis patients and control volunteers. Mult. Scler. 13(5), 670-672 (2007).

34. Smolders J, Menheere P, Kessels A, Damoiseaux J, Hupperts R. Association of vitamin D metabolite levels with relapse rate and disability in multiple sclerosis. Mult. Scler. 14(9), 1220-1224 (2008).

35. Weinstock-Guttman B, Zivadinov R, Qu J et al. Vitamin D metabolites are associated with clinical and MRI outcomes in multiple sclerosis patients. J. Neurol. Neurosurg. Psychiatr. 82(2), 189-195 (2011).

36. Mcleod JG, Hammond SR, Hallpike JF. Epidemiology of multiple sclerosis in Australia. With NSW and SA survey results. Med. J. Aust. 160(3), 117-122 (1994).

37. Kurtzke JF. Geography in multiple sclerosis. J. Neurol. 215(1), 1-26 (1977).

38. Simpson Jr S, Blizzard L, Otahal P, van der Mei I, Taylor B. Latitude is significantly associated with the prevalence of multiple sclerosis: a meta-analysis. J. Neurol. Neurosurg. Psychiatr. 82(10), 1132-1141 (2011).

39. Mccall MG, Brereton TL, Dawson A, Millingen K, Sutherland JM, Acheson ED. Frequency of multiple sclerosis in three Australian cities - Perth, Newcastle, and Hobart. J. Neurol. Neurosurg. Psychiatr. 31(1), 1-9 (1968).

40. Hammond SR, Mcleod JG, Millingen KS et al. The epidemiology of multiple sclerosis in three Australian cities: Perth, Newcastle and Hobart. Brain 111(Pt 1), 1-25 (1988).

41. Skegg DC, Corwin PA, Craven RS, Malloch JA, Pollock M. Occurrence of multiple sclerosis in the north and south of New Zealand. J. Neurol. Neurosurg. Psychiatr. 50(2), 134-139 (1987).

42. Munger KL, Levin LI, Hollis BW, Howard NS, Ascherio A. Serum 25-hydroxyvitamin D levels and risk of multiple sclerosis. JAMA 296(23), 2832-2838 (2006).

43. Munger KL, Zhang SM, O'Reilly E et al. Vitamin D intake and incidence of multiple sclerosis. Neurology 62(1), 60-65 (2004). 
44. Lucas RM, Ponsonby AL, Dear K et al. Sun exposure and vitamin D are independent risk factors for CNS demyelination. Neurology 76(6), 540-548 (2011).

45. van Der Mei IA, Ponsonby AL, Dwyer T et al. Past exposure to sun, skin phenotype, and risk of multiple sclerosis: case-control study. BMJ 327(7410), 316 (2003).

46. van der Mei I, Simpson Jr SL, Stankovich J, Taylor B. Individual and joint action of environmental factors and risk of MS. Neurol. Clin. 29, 233-255 (2011).

47. Islam T, Gauderman WJ, Cozen W, Mack TM. Childhood sun exposure influences risk of multiple sclerosis in monozygotic twins. Neurology 69(4), 381-388 (2007).

48. Kampman MT, Wilsgaard T, Mellgren SI. Outdoor activities and diet in childhood and adolescence relate to MS risk above the Arctic Circle. J. Neurol. 254(4), 471-477 (2007).

49. Brustad M, Alsaker E, Engelsen O, Aksnes L, Lund E. Vitamin D status of middle-aged women at 65-71 degrees $\mathrm{N}$ in relation to dietary intake and exposure to ultraviolet radiation. Public Health Nutr. 7(2), 327-335 (2004).

50. Freedman DM, Dosemeci M, Alavanja MC. Mortality from multiple sclerosis and exposure to residentia and occupational solar radiation:a case-control study based on death certificates. Occup. Environ. Med. 57(6), 418-421 (2000)

51. Westberg M, Feychting M, Jonsson F, Nise G, Gustavsson P. Occupational exposure to UV light and mortality from multiple sclerosis. Am. J. Ind. Med. 52(5), 353-357 (2009).

52. Goldacre MJ, Seagroatt V, Yeates D, Acheson ED. Skin cancer in people with multiple sclerosis: a record linkage study. J. Epidemiol. Community Health 58(2), 142-144 (2004).

53. Willer CJ, Dyment DA, Sadovnick AD, Rothwell PM, Murray TJ, Ebers GC. Timing of birth and risk of multiple sclerosis: population based study. BMJ 330(7483), 120 (2005).

54. Staples J, Ponsonby AL, Lim L. Low maternal exposure to ultraviolet radiation in pregnancy, month of birth, and risk of multiple sclerosis in offspring: longitudinal analysis. BMJ 340, C1640 (2010).

55. Mcdowell TY, Amr S, Langenberg P et al. Time of birth, residential solar radiation and age at onset of multiple sclerosis. Neuroepidemiology 34(4), 238-244 (2010).

56. Mcdowell TY, Amr S, Culpepper WJ et al. Sun exposure, vitamin D and age at disease onset in relapsing multiple sclerosis. Neuroepidemiology 36(1), 39-45 (2011).

57. Cantorna MT, Hayes CE, Deluca HF. 1,25-dihydroxyvitamin D3 reversibly blocks the progression of relapsing encephalomyelitis, a model of multiple sclerosis. Proc. Natl Acad. Sci. USA 93(15), 7861-7864 (1996).

58. Hayes CE. Vitamin D: a natural inhibitor of multiple sclerosis. Proc. Nutr. Soc. 59(4), 531-535 (2000).

59. Hauser SL, Weiner HL, Che M, Shapiro ME, Gilles F, Letvin NL. Prevention of experimental allergic encephalomyelitis (EAE) in the SJL/J mouse by whole body ultraviolet irradiation. J. Immunol. 132(3), 1276-1281 (1984)

60. Tremlett $\mathrm{H}$, van Der Mei IA, Pittas F et al. Monthly ambient sunlight, infections and relapse rates in multiple sclerosis. Neuroepidemiology 31(4), 271-279 (2008).

61. Soilu-Hanninen M, Laaksonen M, Laitinen I, Eralinna JP, Lilius EM, Mononen I. A longitudinal study of serum 25-hydroxyvitamin $D$ and intact parathyroid hormone levels indicate the importance of vitamin D and calcium homeostasis regulation in multiple sclerosis. J. Neurol. Neurosurg. Psychiatr. 79(2), 152157 (2008).

62. Soilu-Hanninen M, Airas L, Mononen I, Heikkila A, Viljanen M, Hanninen A. 25-hydroxyvitamin D levels in serum at the onset of multiple sclerosis. Mult. Scler. 11(3), 266-271 (2005).

63. Simpson S Jr, Taylor B, Blizzard L et al. Higher 25-hydroxyvitamin D is associated with lower relapse risk in multiple sclerosis. Ann. Neurol. 68(2), 193-203 (2010).

64. Mowry EM, Krupp LB, Milazzo $M$ et al. Vitamin D status is associated with relapse rate in pediatriconset multiple sclerosis. Ann. Neurol. 67(5), 618-624 (2010). 


\section{CHAPTER 5}

65. Correale J, Ysrraelit MC, Gaitan MI. Gender differences in 1,25 dihydroxyvitamin D3 immunomodulatory effects in multiple sclerosis patients and healthy subjects. J. Immunol. 185(8), 4948-4958 (2010)

66. Roxburgh RH, Seaman SR, Masterman T et al. Multiple Sclerosis Severity Score: using disability and disease duration to rate disease severity. Neurology 64(7), 1144-1151 (2005).

67. Auer DP, Schumann EM, Kumpfel T, Gossl C, Trenkwalder C. Seasonal fluctuations of gadoliniumenhancing magnetic resonance imaging lesions in multiple sclerosis. Ann. Neurol. 47(2), 276-277. (2000).

68. Embry AF, Snowdon LR, Vieth R. Vitamin D and seasonal fluctuations of gadoliniumenhancing magnetic resonance imaging lesions in multiple sclerosis. Ann. Neurol. 48(2), 271-272 (2000).

69. Kimball SM, Ursell MR, O'Connor P, Vieth R. Safety of vitamin D3 in adults with multiple sclerosis. Am. J. Clin. Nutr. 86(3), 645-651 (2007).

70. Burton JM, Kimball S, Vieth $\mathrm{R}$ et al. A Phase I/II dose-escalation trial of vitamin D3 and calcium in multiple sclerosis. Neurology 74(23), 1852-1859 (2010).

71. Smolders J, Peelen E, Thewissen M et al. Safety and T cell modulating effects of high dose vitamin D3 supplementation in multiple sclerosis. PLoS ONE 5(12), E15235 (2010).

72. Wingerchuk DM, Lesaux J, Rice GP, Kremenchutzky M, Ebers GC. A pilot study of oral calcitriol (1,25dihydroxyvitamin D3) for relapsing-remitting multiple sclerosis. J. Neurol. Neurosurg. Psychiatr. 76(9), 1294-1296 (2005)

73. Goldberg P, Fleming MC, Picard EH. Multiple sclerosis: decreased relapse rate through dietary supplementation with calcium, magnesium and vitamin D. Med. Hypotheses 21(2), 193-200 (1986).

74. Nordvik I, Myhr KM, Nyland H, Bjerve KS. Effect of dietary advice and D3 supplementation in newly diagnosed MS patients. Acta Neurol. Scand. 102(3), 143-149 (2000).

75. Mosayebi G, Ghazavi A, Ghasami K, Jand Y, Kokhaei P. Therapeutic effect of vitamin D3 in multiple sclerosis patients. Immunol. Invest. 40(6), 627-639 (2011).

76. Mahon BD, Gordon SA, Cruz J, Cosman F, Cantorna MT. Cytokine profile in patients with multiple sclerosis following vitamin D supplementation. J. Neuroimmunol. 134(1-2), 128-132 (2003).

77. Smolders J, Hupperts R, Barkhof F et al. Efficacy of vitamin D(3) as add-on therapy in patients with relapsing-remitting multiple sclerosis receiving subcutaneous interferon beta-1a: a Phase II, multicenter, double-blind, randomized, placebo-controlled trial. J. Neurol. Sci. doi:10.1016/j.jns.2011.04.013 (2011) (Epub ahead of print).

78. Beiske AG, Svensson E, Sandanger I et al. Depression and anxiety amongst multiple sclerosis patients. Eur. J. Neurol. 15(3), 239-245 (2008).

79. Branas P, Jordan R, Fry-Smith A, Burls A, Hyde C. Treatments for fatigue in multiple sclerosis: a rapid and systematic review. Health Technol. Assess 4(27), 1-61 (2000).

80. Chiaravalloti ND, Deluca J. Cognitive impairment in multiple sclerosis. Lancet Neurol. 7(12), 1139-1151 (2008).

81. Janssens AC, Van Doorn PA, De Boer JB, Van Der Meche FG, Passchier J, Hintzen RQ. Impact of recently diagnosed multiple sclerosis on quality of life, anxiety, depression and distress of patients and partners. Acta Neurol. Scand. 108(6), 389-395 (2003).

82. Krupp LB, Alvarez LA, Larocca NG, Scheinberg LC. Fatigue in multiple sclerosis. Arch Neurol 45(4), 435437 (1988).

83. Knippenberg S, Bol Y, Damoiseaux J, Hupperts R, Smolders J. Vitamin D status in patients with MS is negatively correlated with depression, but not with fatigue. Acta Neurol. Scand. 124(3), 171-175 (2010).

84. Ganji V, Milone C, Cody MM, Mccarty F, Wang YT. Serum vitamin D concentrations are related to depression in young adult US population: the Third National Health and Nutrition Examination Survey. Int. Arch. Med. 3, 29 (2010). 
85. Jorde R, Sneve M, Figenschau Y, Svartberg J, Waterloo K. Effects of vitamin D supplementation on symptoms of depression in overweight and obese subjects: randomized double blind trial. J. Intern. Med. 264(6), 599-609 (2008).

86. May HT, Bair TL, Lappe DL et al. Association of vitamin D levels with incident depression among a general cardiovascular population. Am. Heart J. 159(6), 1037-1043 (2010).

87. Gloth FM, 3rd, Alam W, Hollis B. Vitamin D vs broad spectrum phototherapy in the treatment of seasonal affective disorder. J. Nutr. Health Aging 3(1), 5-7 (1999).

88. Lemire JM. Immunomodulatory actions of 1,25-dihydroxyvitamin D3. J. Steroid Biochem. Mol. Biol. 53(1-6), 599-602. (1995).

89. Kubera M, Lin AH, Kenis G, Bosmans E, Van Bockstaele D, Maes M. Antiinflammatory effects of antidepressants through suppression of the interferon-gamma/interleukin-10 production ratio. J. Clin. Psychopharmacol. 21(2), 199-206 (2001).

90. Xia Z, Depierre JW, Nassberger L. Tricyclic antidepressants inhibit IL-6, IL-1 beta and TNF-alpha release in human blood monocytes and IL-2 and interferon-gamma in T cells. Immunopharmacology 34(1), 2737 (1996).

91. Walbert T, Jirikowski GF, Prufer K. Distribution of 1,25-dihydroxyvitamin D3 receptor immunoreactivity in the limbic system of the rat. Horm. Metab. Res. 33(9), 525-531 (2001).

92. Ruiz-Irastorza G, Egurbide MV, Olivares N, Martinez-Berriotxoa A, Aguirre C. Vitamin D deficiency in systemic lupus erythematosus: prevalence, predictors and clinical consequences. Rheumatology (Oxford) 47(6), 920-923 (2008).

93. Ruiz-Irastorza G, Gordo S, Olivares N, Egurbide MV, Aguirre C. Changes in vitamin D levels in patients with systemic lupus erythematosus: effects on fatigue, disease activity, and damage. Arthritis Care Res. (Hoboken) 62(8), 1160-1165 (2010).

94. Kalueff AV, Lou YR, Laaksi I, Tuohimaa P. Increased anxiety in mice lacking vitamin D receptor gene. Neuroreport 15(8), 1271-1274 (2004).

95. Bossola M, Ciciarelli C, Di Stasio E et al. Correlates of symptoms of depression and anxiety in chronic hemodialysis patients. Gen. Hosp. Psychiatry 32(2), 125-131 (2010).

96. Sanders KM, Stuart AL, Williamson EJ et al. Annual high-dose vitamin D3 and mental well-being: randomised controlled trial. Br. J. Psychiatry 198(5), 357-364 (2011).

97. Eyles DW, Smith S, Kinobe R, Hewison M, McGrath JJ. Distribution of the vitamin D receptor and 1 alpha-hydroxylase in human brain. J. Chem. Neuroanat. 29(1), 21-30 (2005).

98. Buell JS, Scott TM, Dawson-Hughes B et al. Vitamin D is associated with cognitive function in elders receiving home health services. J. Gerontol. A Biol. Sci. Med. Sci. 64(8), 888-895 (2009).

99. Llewellyn DJ, Lang IA, Langa KM et al. Vitamin D and risk of cognitive decline in elderly persons. Arch. Intern. Med. 170(13), 1135-1141 (2010).

100. Oudshoorn C, Mattace-Raso FU, van Der Velde N, Colin EM, van Der Cammen TJ. Higher serum vitamin D3 levels are associated with better cognitive test performance in patients with Alzheimer's disease. Dement. Geriatr. Cogn. Disord. 25(6), 539-543 (2008).

101. Marrie RA, Cutter G, Tyry T, Vollmer T. A cross-sectional study of bone health in multiple sclerosis. Neurology 73(17), 1394-1398 (2009).

102. Cosman F, Nieves J, Komar L et al. Fracture history and bone loss in patients with MS. Neurology 51(4), 1161-1165 (1998)

103. Bazelier MT, Van Staa TP, Uitdehaag BM et al. The risk of fracture in patients with multiple sclerosis: the UK general practice research database. J. Bone Miner. Res. 26(9), 2271-2279 (2011).

104. Logan WC Jr, Sloane R, Lyles KW, Goldstein B, Hoenig HM. Incidence of fractures in a cohort of veterans with chronic multiple sclerosis or traumatic spinal cord injury. Arch. Phys. Med. Rehabil. 89(2), 237-243 (2008).

105. Hearn AP, Silber E. Osteoporosis in multiple sclerosis. Mult. Scler. 16(9), 1031-1043 (2010). 


\section{CHAPTER 5}

106. Nilsagard Y, Lundholm C, Denison E, Gunnarsson LG. Predicting accidental falls in people with multiple sclerosis - a longitudinal study. Clin. Rehabil. 23(3), 259-269 (2009).

107. Peterson EW, Cho CC, Von Koch L, Finlayson ML. Injurious falls among middle aged and older adults with multiple sclerosis. Arch. Phys. Med. Rehabil. 89(6), 1031-1037 (2008).

108. Cameron MH, Poel AJ, Haselkorn JK, Linke A, Bourdette D. Falls requiring medical attention among veterans with multiple sclerosis: a cohort study. J. Rehabil. Res. Dev. 48(1), 13-20 (2011).

109. Finlayson ML, Peterson EW, Cho CC. Risk factors for falling among people aged 45 to 90 years with multiple sclerosis. Arch. Phys. Med. Rehabil. 87(9), 1274-1279 (2006).

110. Moen SM, Celius EG, Nordsletten L, Holmoy T. Fractures and falls in patients with newly diagnosed clinically isolated syndrome and multiple sclerosis. Acta Neurol. Scand. Suppl. (191), 79-82 (2011).

111. Moen SM, Celius EG, Sandvik L, Nordsletten L, Eriksen EF, Holmoy T. Low bone mass in newly diagnosed multiple sclerosis and clinically isolated syndrome. Neurology 77(2), 151-157 (2011).

112. Cranney A, Horsley T, O'Donnell $S$ et al. Effectiveness and safety of vitamin $D$ in relation to bone health. Evid. Rep. Technol. Assess (Full Rep.) 158, 1-235 (2007).

113. Kampman MT, Eriksen EF, Holmoy T. Multiple sclerosis, a cause of secondary osteoporosis? What is the evidence and what are the clinical implications? Acta Neurol. Scand. Suppl. (191), 44-49 (2011).

114. DIPART (Vitamin D Individual Patient Analysis of Randomized Trials) Group. Patient level pooled analysis of 68500 patients from seven major vitamin D fracture trials in US and Europe. BMJ 340, B5463 (2010).

115. Bischoff-Ferrari HA, Dawson-Hughes B, Staehelin HB et al. Fall prevention with supplemental and active forms of vitamin D: a meta-analysis of randomised controlled trials. BMJ 339, B3692 (2009).

116. Winzenberg TM, Jones G. Cost- effectiveness of nutritional interventions for bone health in children and young adults - what is known and where are the gaps? In: Nutrients, Dietary Supplements, and Nutriceuticals: Cost Analysis versus Clinical Benefits. Watson RR, Gerald JK, Preedy VR (Eds). Springer/Humana Press, NY, USA (2011).

117. Steffensen LH, Jorgensen L, Straume B, Mellgren SI, Kampman MT. Can vitamin D(3) supplementation prevent bone loss in persons with MS? A placebo-controlled trial. J. Neurol. 258(9), 1624-1631 (2011).

118. Sibley WA, Bamford CR, Clark K. Clinical viral infections and multiple sclerosis. Lancet 1(8441), 13131315. (1985).

119. Sabetta JR, Depetrillo P, Cipriani RJ, Smardin J, Burns LA, Landry ML. Serum 25-hydroxyvitamin d and the incidence of acute viral respiratory tract infections in healthy adults. PLOS ONE 5(6), E11088 (2010).

120. Wang TT, Nestel FP, Bourdeau V et al. Cutting edge: 1,25 -dihydroxyvitamin D3 is a direct inducer of antimicrobial peptide gene expression. J. Immunol. 173(5), 2909-2912 (2004).

121. Gombart AF, Borregaard N, Koeffler HP. Human cathelicidin antimicrobial peptide (CAMP) gene is a direct target of the vitamin $D$ receptor and is strongly upregulated in myeloid cells by $1,25-$ dihydroxyvitamin D3. FASEB J. 19(9), 1067-1077 (2005).

122. Laaksi I, Ruohola JP, Mattila V, Auvinen A, Ylikomi T, Pihlajamaki H. Vitamin D supplementation for the prevention of acute respiratory tract infection: a randomized, double-blinded trial among young Finnish men. J. Infect. Dis. 202(5), 809-814 (2010).

123. Urashima $M$, Segawa $T$, Okazaki $M$, Kurihara $M$, Wada $Y$, Ida $H$. Randomized trial of vitamin $D$ supplementation to prevent seasonal influenza A in schoolchildren. Am. J. Clin. Nutr. 91(5), 1255-1260 (2010).

124. White JH. Vitamin D signaling, infectious diseases, and regulation of innate immunity. Infect. Immun. 76(9), 3837-3843 (2008).

125. Moore FG, Wolfson C. Human herpes virus 6 and multiple sclerosis. Acta Neurol. Scand. 106(2), 63-83 (2002).

126. Santiago O, Gutierrez J, Sorlozano A, De Dios Luna J, Villegas E, Fernandez O. Relation between Epstein-Barr virus and multiple sclerosis: analytic study of scientific production. Eur. J. Clin. Microbiol. Infect. Dis. 29(7), 857-866 (2010). 
127. Hayes CE, Donald Acheson E. A unifying multiple sclerosis etiology linking virus infection, sunlight, and vitamin D, through viral interleukin-10. Med. Hypotheses 71(1), 85-90 (2008).

128. Hølmoy T. Vitamin D status modulates the immune response to Epstein Barr virus: synergistic effect of risk factors in multiple sclerosis. Med. Hypotheses 70(1), 66-69 (2008).

129. Riise T, Nortvedt MW, Ascherio A. Smoking is a risk factor for multiple sclerosis. Neurology $61(8), 1122-$ 1124 (2003).

130. Hernan MA, Jick SS, Logroscino G, Olek MJ, Ascherio A, Jick H. Cigarette smoking and the progression of multiple sclerosis. Brain 128(Pt 6), 1461-1465 (2005).

131. Pittas F, Ponsonby AL, van Der Mei IA et al. Smoking is associated with progressive disease course and increased progression in clinical disability in a prospective cohort of people with multiple sclerosis. J. Neurol. 256(4), 577-585 (2009).

132. Brot $\mathrm{C}$, Jorgensen NR, Sorensen $\mathrm{OH}$. The influence of smoking on vitamin $\mathrm{D}$ status and calcium metabolism. Eur. J. Clin. Nutr. 53(12), 920-926 (1999).

133. Ward KD, Klesges RC. A meta-analysis of the effects of cigarette smoking on bone mineral density. Calcif. Tissue Int. 68(5), 259-270 (2001).

134. Rosen CJ. Clinical practice. Vitamin D insufficiency. N. Engl. J. Med. 364(3), 248-254 (2011).

135. Heaney RP, Davies KM, Chen TC, Holick MF, Barger-Lux MJ. Human serum 25-hydroxycholecalciferol response to extended oral dosing with cholecalciferol. Am. J. Clin. Nutr. 77(1), 204-210 (2003).

136. Vieth $R$. Why the optimal requirement for vitamin D3 is probably much higher than what is officially recommended for adults. J. Steroid Biochem. Mol. Biol. 89-90(1-5), 575-579 (2004).

137. Kimball S, Vieth R, Dosch HM et al. Cholecalciferol plus calcium suppresses abnormal PBMC reactivity in patients with multiple sclerosis. J. Clin. Endocrinol. Metab. 96(9), 2826-2834 (2011).

138. Knippenberg S, Smolders J, Thewissen M et al. Effect of vitamin D3 supplementation on peripheral B cell differentiation and isotype switching in patients with multiple sclerosis. Mult. Scler. doi: $10.1177 / 1352458511412655$ (2011) (Epub ahead of print).

Websites

201. NIH clinical trial: supplementation of VigantOL ${ }^{\circledR}$ oil versus placebo as add-on in patients with relapsing remitting multiple sclerosis receiving rebif ${ }^{\circledR}$ Treatment (SOLAR). http://clinicaltrials.gov/ct2/show/NCT01285401 (Accessed 10 October 2011)

202. NIH clinical trial: a multicentre study of the efficacy and safety of supplementary treatment with cholecalciferol in patients with relapsing multiple sclerosis treated with subcutaneous interferon beta1a $44 \mu \mathrm{g} 3$ times weekly (CHOLINE). http://clinicaltrials.gov/ct2/show/NCT01198132 (Accessed 10 October 2011)

203. National Multiple Sclerosis Society home page. www.nmss.org (Accessed 10 October 2011)

204. National Osteoporosis Guideline Group. www.shef.ac.uk/NOGG (Accessed 10 October 2011)

205. Institute of Medicine. www.iom.edu/Reports/2010/Dietary- Reference-Intakes-for-Calcium-andVitamin-D.aspx (Accessed 10 October 2011) 



\section{Chapter 6}

\section{Vitamin D status in MS correlates negatively with retinal nerve fibre layer thickness}

Adapted from: S. Knippenberg, J. Damoiseaux, G. Porro, M. van de Maegdenbergh, E. Sanders, R. Hupperts.

Vitamin D status in MS correlates negatively with retinal nerve fibre layer thickness. Submitted 


\section{CHAPTER 6}

\section{Abstract}

Background: A poor vitamin D status has been associated with clinical active disease in multiple sclerosis (MS). Visual dysfunction is common in MS and has been linked to poor vitamin D status in other populations, but not in MS. We hypothesized that vitamin D status is positively associated with visual function in MS patients.

Methods: Twenty-seven MS patients with short disease duration ( $\leq 3$ years), with or without optic neuritis (ON) in history were included. Serum levels of 25-hydroxyvitamin $\mathrm{D}(25(\mathrm{OH}) \mathrm{D})$ were measured. Visual acuity, colour vision deficits, visual evoked potentials (VEP) and retinal nerve fibre layer (RNFL) thickness using optical coherence tomography (OCT) were assessed. In addition, all patients underwent standard neurological examination to determine expanded disability status scale score and relapse rate.

Results: No correlations were found between the visual outcomes visual acuity, colour visual acuity, VEP recordings and serum 25(OH)D levels in the total cohort. Surprisingly, we found a correlation between higher 25(OH)D levels and decreased RNFL thickness in the total cohort $(\mathrm{R}=-0.439, \mathrm{P}=0.025)$. This correlation was in particular seen in MS patients without a history of ON ( $R=-0.661, P=0.007)$.

Discussion: Although functional visual outcome measures did not correlate with vitamin $\mathrm{D}$ status in this cohort, RNFL thickness correlated negatively with vitamin $\mathrm{D}$ status. This might indicate that a high vitamin D status in MS is not sufficient protective for axonal damage, in particular in patients without ON. Since our finding is in contrast with current concepts, underlying mechanisms need to be further explored. 


\section{Introduction}

Multiple Sclerosis (MS) is a chronic inflammatory disease of the central nervous system (CNS), probably of autoimmune origin (1). This inflammation can cause a variety of symptoms, but visual loss is one of the most common clinical manifestations of MS (2). In $20 \%$ of patients with MS, optic neuritis (ON) is presenting symptom and $50 \%$ of patients with isolated ON develop MS within 15 years (3). Not only the optic nerves, but the whole afferent visual pathway, including retina, chiasm and tracts, can be subject of inflammation (4). Indeed, MS patients without a clinical history of ON, also may exhibit poor visual function, including worse scores on low-contrast visual acuity and colour sensitivity testing, when compared with age-matched controls (5).

A growing body of research suggests that vitamin $D$ affects inflammation and modulates diseases with inflammatory aetiologies, including MS (6-10). A poor vitamin $D$ status, as reflected by serum levels of 25 -hydroxyvitamin $D(25(\mathrm{OH}) \mathrm{D})$, is often seen in MS and has been associated with clinical progression (11) and high relapse rate (12, 13). Visual acuity is part of the expanded disability status scale (EDSS) score, and high 25(OH)D levels are shown to correlate with low EDSS scores (13). However, despite the high prevalence of visual loss in MS and the importance of it in quality of life (2), the relationship with vitamin $D$ on merely visual outcome measures is unexplored. We hypothesized that a poor vitamin D status correlates with poor visual outcome measures in MS patients. Therefore our aim was to explore the relationship between vitamin $D$ status and functional visual outcome measures such as visual acuity, colour vision sensitivity and visual evoked potentials (VEP) in MS patients. In addition, we assessed optical coherence tomography (OCT) to evaluate the structural composition of the retina, as measured by thickness of the retinal nerve fibre layer (RNFL), and its association with vitamin D status in MS patients.

\section{Methods}

\section{Subjects and study design}

All subjects were prospectively recruited from baseline visit of an ongoing pilot study (clinical trial.gov; NCT00910598) running in the academic MS center Limburg and the Amphia Hospital Breda, the Netherlands. Subjects were eligible for inclusion if they had MS according to the revised McDonald criteria 2010 (14), and were treated with glatiramer acetate $(\mathrm{GA})$ or untreated with immune modulation. Exclusion criteria were disease duration longer than 3 years, use of other immune modulation than GA, use of glucocorticosteroids $<6$ weeks before baseline measurement, and occurrence of a relapse $<6$ weeks before baseline measurement. Medical history, particularly with respect to visual symptoms such as ON, was taken from all study subjects. Patients known with visual ophthalmologic disease (e.g. glaucoma or cataract), and ON within 3 


\section{CHAPTER 6}

months prior to inclusion were excluded. The neurological status of all MS patients was determined and included the EDSS score and annualized relapse rate (ARR). The characteristics of the patients are presented in Table 1.

Table 1. Demographic and clinical characteristics of all participants

\begin{tabular}{|c|c|c|c|c|c|}
\hline & \multirow{2}{*}{\multicolumn{2}{|c|}{$\begin{array}{l}\text { Mean (SD) / Median } \\
\left(\text { IQR) }{ }^{+}\right. \\
\text {MS-NON }(n=15)\end{array}$}} & \multirow{2}{*}{\multicolumn{2}{|c|}{$\begin{array}{l}\text { Mean (SD) / Median } \\
\left(\text { IQR) }{ }^{\dagger}\right. \\
\text { MS-ON (n=12) }\end{array}$}} & P-value \\
\hline & & & & & \\
\hline Age(yr) & \multicolumn{2}{|c|}{$38.8(9.0)$} & \multicolumn{2}{|c|}{40.1 (9.9) } & 0.733 \\
\hline Disease duration since diagnosis $(y r) \dagger$ & \multicolumn{2}{|c|}{$1.2(0.3-2.4)$} & \multicolumn{2}{|c|}{$1.0(0.1-1.7)$} & 0.156 \\
\hline EDSS score ${ }^{\dagger}$ & \multicolumn{2}{|c|}{$1.0(1.0-1.5)$} & \multicolumn{2}{|c|}{$1.0(1.0-1.5)$} & 0.527 \\
\hline ARRt & \multicolumn{2}{|c|}{$1.0(0-1.0)$} & \multicolumn{2}{|c|}{$0(0-1.0)$} & 0.220 \\
\hline \multirow[t]{2}{*}{ Deseasonalised 25(OH)D nmol/L† } & \multicolumn{2}{|c|}{64.7 (53.3-84.9) } & \multicolumn{2}{|c|}{$86.9(66.6-96.7)$} & 0.130 \\
\hline & $\mathrm{n} / \mathrm{N}$ & $\%$ & $\mathrm{n} / \mathrm{N}$ & $\%$ & Chi-square \\
\hline \multicolumn{6}{|l|}{ Sex } \\
\hline Female / Male & $12 / 3$ & $80 \% / 20 \%$ & $12 / 0$ & $100 \% / 0 \%$ & 0.231 \\
\hline \multicolumn{6}{|l|}{ Immunomodulatory treatment } \\
\hline None / GA & $8 / 7$ & $53 \% / 47 \%$ & $3 / 9$ & $25 \% / 75 \%$ & 0.239 \\
\hline
\end{tabular}

†Due to a skewed distribution, median and interquartile range (IQR) are provided.

Abbreviations: ARR annualized relapse rate; EDSS expanded disability status scale; GA: Glatiramer Acetate; 25(OH)D 25-hydroxy-vitamin-D

\section{Ethical statement}

Written informed consent was acquired from all subjects participating in this study, according to the declaration of Helsinki. The study was approved by both the ethics committee 'independent review board' and the institutional ethical committees 'Local Advisory Board on Scientific Research' for approval in academic MS center Limburg and 'the medical ethical committee of Amphia' for approval in Amphia Hospital Breda.

\section{Visual acuity and colour vision sensitivity assessment}

An ophthalmologic examination, including visual acuity, colour vision sensitivity, refraction, applanation tonometry, and dilated ophthalmoscopy was performed in all subjects. Visual acuity was assessed using Snellen charts at $6 \mathrm{~m}$, of which Snellen acuity equivalent was determined. Snellen visual acuity was expressed as decimal value, but it was transformed to LogMAR system to be analyzed (15).

Colour vision sensitivity was recorded using Ishihara 24 colour plates. The Ishihara test was first published in 1906 and has been reprinted in numerous editions over the years. The Ishihara test is still considered as the gold standard and is the most used 
colour vision test (16). All testing was performed for each eye separately and performed by trained technicians experienced in research examinations.

\section{Visual evoked potential recordings}

Monocular visual stimulation was performed using a pattern-reversal checkerboard screen. A recording electrode was placed at $\mathrm{Oz}^{\prime}$ (10-20 system; $\mathrm{Oz}$ at $10 \%$ above line inion-occiput) and the reference at Fz. An average of 100 trials ( 50 patterns each) was analyzed according to laboratory reference values. In all eyes, the amplitude and the latency of P100 were evaluated.

\section{Optical coherence tomography}

RNFL thickness was measured with Stratus 3 OCT (Carl Zeiss B.V, Sliedrecht, the Netherlands) using the "Fast RNFL thickness" protocol (Software V4.0) by trained personnel. Scans were repeated 3 times and assessed for centering and signal strength. A good quality image was defined as having a signal strength $\leq 6$. The results of 3 scans were averaged to obtain mean RNFL thickness and quadrant thickness (temporal, superior, nasal and inferior) in micrometers $(\mu \mathrm{m})$. The minimum (more abnormal of the two eyes) RNFL thickness was used for the analysis.

\section{Deseasonalised vitamin D status}

Serum 25(OH)D level was measured using a commercially-available automated chemiluminescence assay (Immunodiagnostic Systems, Liège, Belgium). All samples were stored at $-80^{\circ} \mathrm{C}$ and shielded from light. All measurements were performed in sequential batches in order of blood draw following the end of inclusion of the study. Patients were included throughout the year, which can cause variability in 25(OH)D status. To remove this variability, 25(OH)D was deseasonalised using a sinusoidal regression model as described previously (17):

$y_{t}=\beta_{0}+\beta_{1} \sin \left(\frac{2 \pi t}{365}\right)+\beta_{2} \cos \left(\frac{2 \pi t}{365}\right)$

where $y_{t}$ indicates measured serum 25(OH)D concentration, $t$ indicates the day of the year the sample was collected, and $\beta_{j}(j=0,1,2)$ are estimated regression coefficients.

\section{Statistical analysis}

SPSS software (SPSS Inc., version 12.0, Chicago, USA) was used for statistical analysis. Values are provided as mean with standard deviation (SD) or as medians with interquartile range (IQR). Gender, disease duration, annualized relapse rate, and EDSS scores were compared between MS patients without ON in history and MS patients with ON in history using independent student T-test or Mann-Whitney test, depending on the distribution of the variables. Correlations were carried out using the Pearson's 


\section{CHAPTER 6}

bivariate or Spearman rank correlation as appropriate. Pearson Chi-square was used to assess differences in sex and use of immune modulating treatment in patients with $O N$ and patients without $\mathrm{ON}$ in history. Because we hypothesized that a poor vitamin $D$ status correlated with poor visual outcomes, we did not correct for multiple testing. Pvalues of $<0.05$ were considered significant.

\section{Results}

Subjects

We included $27 \mathrm{MS}$ patients. Twelve patients had ON in history. Therefore, we divided our population in two subgroups; one group of MS patients without ON (MS-NON, $\mathrm{N}=15$ ) in history, and one group with prior ON (MS-ON, N=12). Median deseasonalised 25(OH)D level in all MS patients was $74.6 \mathrm{nmol} / \mathrm{L}$ (IQR 55.5-93.4).

\section{Visual outcome measures MS-NON and MS-ON patients}

Visual outcome measures were compared between MS-NON and MS-ON patients (Figure 1A). Visual acuity was normal in 14/15 MS-NON patients. One MS-NON patient had diminished Snellen visual acuity of 0.7 . Median visual acuity was slightly reduced in MS-ON patients (0.9; IQR 0.7-1.0; $\mathrm{p}=0.002)$. There was no difference in colour vision as measured by Ishihara colour plates between MS-NON and MS-ON patients (number of plates wrong was 0 (IQR 0-0) vs. 0 (IQR 0-12), respectively; $p=0.066$ ).

In the VEP measurements, amplitude of P100 was not significantly different between MS-NON and MS-ON patients (8.3 $\mu \mathrm{V}$ (IQR 7.1-11.3) vs. $6.9 \mu \mathrm{V}$ (IQR 4.0-12.0); $\mathrm{p}=0.119$ ) (Figure 1B). However, latency of P100 was prolonged in the MS-ON group $112.9 \mathrm{msec}$ (IQR 106.2-131.1) vs. $100.0 \mathrm{msec}$ (IQR 98.1-110.0) in MS-NON vs.; $(p=0.010)$ (Figure 1C).

In the OCT measurements, average RNFL thickness was significantly higher in MSNON patients compared to MS-ON patients $(96.5 \mu \mathrm{m}( \pm 13.9)$ vs. $83.7 \mu \mathrm{m}( \pm 17.3)$; $p=0.036$ ). There was no specific difference in thickness in the quadrants between the two groups, however, there was a trend towards a higher RNFL thickness in the inferior quadrant in MS-NON patients compared to MS-ON patients $(125.3 \mu \mathrm{m}( \pm 19.6)$ vs. (108.4 $\mu \mathrm{m}( \pm 24.5)$ ); $p=0.052$ ) (Figure 1D).

Visual acuity correlates with VEP recordings and RNFL thickness in all MS subjects Decreased visual acuity correlated with increased latency of P100 in all MS patients (Spearman correlation R:-0.602, $\mathrm{p}=0.002$ ). Accordingly, visual acuity correlated with higher average RNFL thickness in all MS patients (Spearman correlation $R=0.680$, $\mathrm{p}<0.001)$, and in MS-NON patients $(\mathrm{R}=0.549, \mathrm{p}=0.034)$. In addition, higher average RNFL thickness correlated with a reduced latency of P100 in all MS subjects (Spearman correlation $\mathrm{R}=-0.483, \mathrm{p}=0.017$ ). 

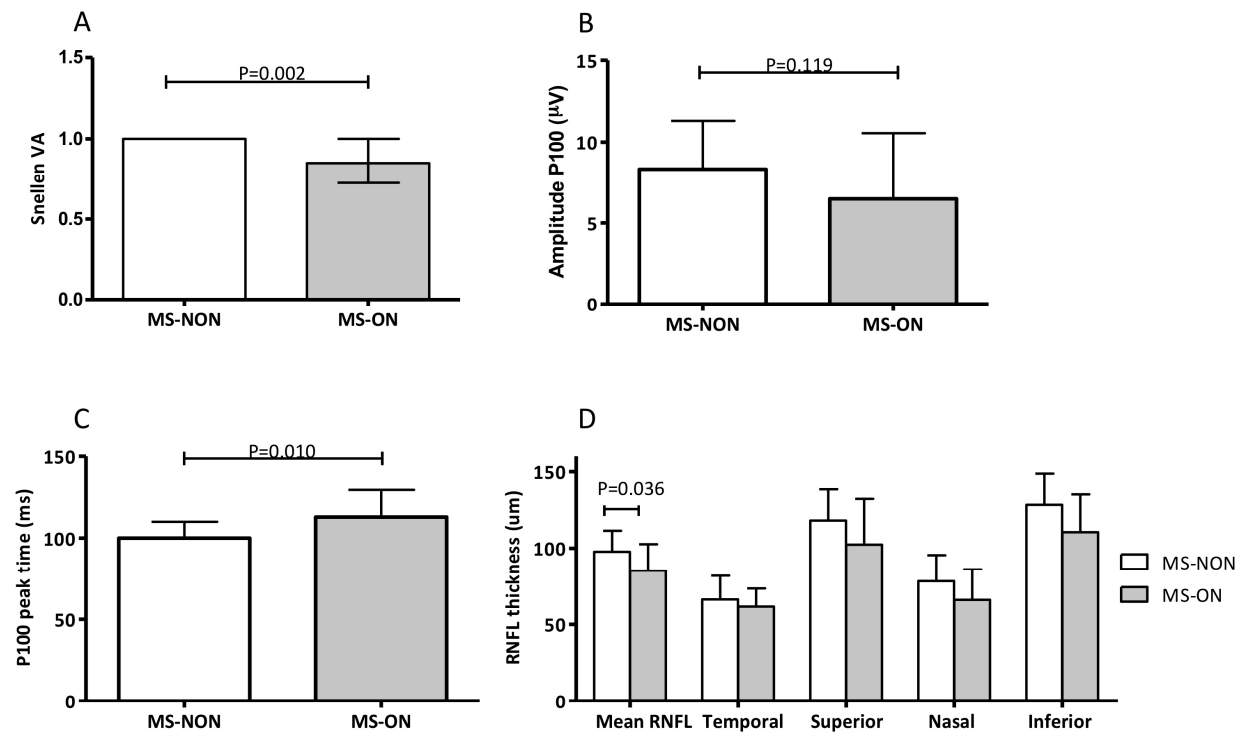

Figure 1. Comparison of visual outcome measures between eyes with and without optic neuritis in multiple sclerosis patients. Median visual acuity (A), median amplitude of P100 (B), median latency of P100 (C) and mean retinal nerve fibre layer thickness (D) was compared between eyes without optic neuritis and eyes with optic neuritis in multiple sclerosis patients. Means with corresponding standard deviation or median with interquartile range are shown.

Visual acuity and VEP recordings do not correlate with deseasonalised 25(OH)D levels Deseasonalised 25(OH)D did not correlate with visual acuity in all MS subjects (Spearman correlation R: $-0.107, p=0.595)$, or in MS-NON patients (Spearman correlation R:$0.127 ; p=0.653)$. A trend was seen towards a significant correlation between higher deseasonalised 25(OH)D and higher VA in MS-ON patients (Spearman correlation R: $0.549, p=0.065)$. In addition, there was no correlation between deseasonalised $25(\mathrm{OH}) \mathrm{D}$ and colour vision sensitivity (Spearman correlation $\mathrm{R}=0.049, p=0.810$ in all MS patients; $R=0.247, p=0.374$ in MS-NON patients and $R=-0.383, p=0.219$ in MS-ON patients). We could not demonstrate a correlation between the VEP recordings and deseasonalised 25(OH)D in MS-NON and MS-ON patients.

Retinal nerve fibre layer thickness correlates negatively with deseasonalised $25(\mathrm{OH}) \mathrm{D}$ levels

Next, we assessed the correlation between deseasonalised 25(OH)D and mean RNFL thickness in all MS patients. A significant correlation was seen in all MS patients be- 


\section{CHAPTER 6}

tween higher deseasonalised 25(OH)D levels and decreased mean RNFL thickness (Spearman correlation $\mathrm{R}=-0.439, \mathrm{p}=0.025$ ) (Figure 2). The inferior quadrant appeared to correlate best with deseasonalised $25(\mathrm{OH}) \mathrm{D}$ (Spearman correlation $\mathrm{R}=-\mathbf{0 . 4 2 2}$, $p=0.032$ ). The correlation between deseasonalised 25(OH)D and mean RNFL thickness was stronger in MS-NON patients (Spearman correlation $\mathrm{R}=-0.661, \mathrm{p}=0.007$ ) compared to MS-ON patients (Spearman correlation $\mathrm{R}=0.182, \mathrm{p}=0.593$ ). In MS-NON patients, the inferior and superior quadrant showed the best correlation with deseasonalised $25(\mathrm{OH}) \mathrm{D}$ (Spearman correlation $\mathrm{R}=-0.568, \mathrm{p}=0.027$ and $\mathrm{R}=-0.610, \mathrm{p}=0.010$ respectively).

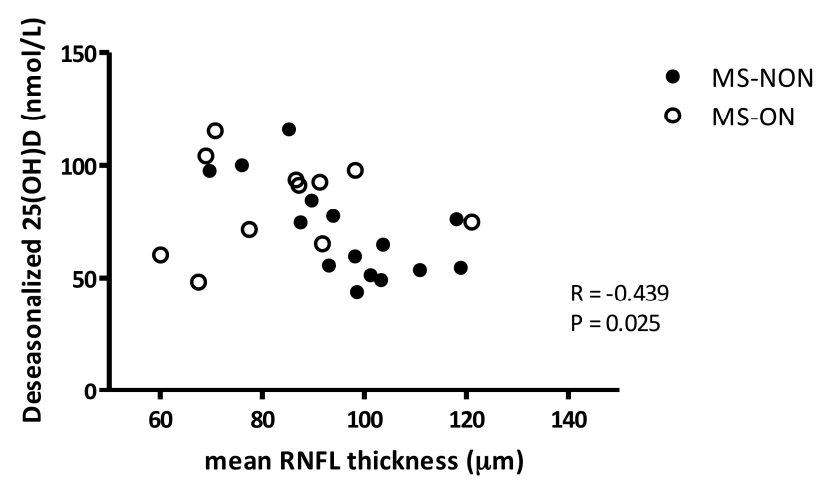

Figure 2. Correlation between retinal nerve fibre layer thickness and vitamin $D$ status. The correlation between retinal nerve fibre layer thickness and deseasonalised 25(OH)D is shown. Open dots represent MS patients with optic neuritis in history, closed dots represent MS patients without optic neuritis in history. Spearman correlation coefficient is shown.

\section{Discussion}

In this study, we could not demonstrate a correlation between deseasonalised 25(OH)D levels and functional outcome measures of vision, as visual acuity, colour vision sensitivity, and latency and amplitude of P100 in VEP recordings. However, in contrast with our hypothesis, we found a rather unexpected significant correlation between elevated deseasonalised 25(OH)D levels and reduced RNFL thickness, in particular in MS patients without a history of ON.

Our results suggest that there is no correlation between functional visual outcome measures and vitamin D status in MS patients. This is in contrast with previous findings 
in other patient populations. Recently, low vitamin $D$ status has been associated with the prevalence of age-related macular degeneration (AMD) (18). AMD is the leading cause of irreversible loss of vision in developed countries (19), in which inflammation is thought to be involved in the pathogenesis (20). Therefore, the underlying mechanism in this association may be the effect of vitamin $D$ on inflammation. The active metabolite of vitamin $D\left(1,25\right.$-dihydroxyvitamin $D\left(1,25(\mathrm{OH})_{2} \mathrm{D}\right)$ has been demonstrated to suppress pro-inflammatory cytokines in vitro, with simultaneous stimulation of antiinflammatory cytokines (reviewed in (10)). Interestingly, in experimental autoimmune encephalitis (EAE), the animal model of MS, an imbalance in pro-inflammatory cytokines and anti-inflammatory cytokines towards pro-inflammatory cytokines was observed in the optic nerve (21). Therefore, vitamin D may restore this cytokine balance in the optic nerve and thereby exhibit its beneficial effect. Alternatively, a poor vitamin D status may impair poorly defined local functions of vitamin D. A local role in ocular functioning for vitamin $D$ is supported by evidence that vitamin $D$ receptor (VDR) is expressed in vertebrate retinal tissue $(22,23)$ and also in human cultured retinal endothelial cells (24). A role for vitamin $D$ in ocular functioning is further supported by the finding that vitamin $D$ supplementation had a beneficial effect on myopia and nightblindness in marine and naval personnel who suffered from malnutrition (25). More recently, high vitamin $D$ status was also shown to correlate with better visual acuity in healthy elderly adults (26).

Against our expectations, we found an inverse correlation between the structural outcome measure RNFL thickness and vitamin D status; high vitamin D levels correlated with reduced thickness of the RNFL. This was in particular seen in MS-NON patients. The retina is the only location where unmyelinated axons, and thus axonal damage, can be imaged directly. Axonal damage is considered the major cause of irreversible disability in MS (1). Hence, quantification of the RNFL by OCT has the potential to monitor neurodegeneration in vivo (27). Previous research showed correlations between RNFL thickness and measures of brain atrophy on magnetic resonance imaging (MRI) (28-30). Although neuroprotective properties of vitamin $D$ have been hypothesized (31), studies exploring the association between vitamin $D$ status and measures of brain atrophy or RNFL thickness in MS are scarce. Similar to our findings, results from a recent cross-sectional study among MS patients, did not support a neuroprotective role of vitamin D. Brain parenchyma volume in MRI was inversely associated with the $24,25(\mathrm{OH})_{2} \mathrm{D} / 25(\mathrm{OH}) \mathrm{D}$ ratio. The exact biological significance of this ratio is unclear, but it is suggested to reflect turnover of $25(\mathrm{OH}) \mathrm{D}$. This finding may implicate the metabolic process of $25(\mathrm{OH}) \mathrm{D}$ as a potential contributing factor in axonal damage and eventually MS progression (11).

Interestingly, in MS-ON patients, the correlation between high deseasonalised 25(OH)D levels and decreased RNFL thickness was absent. Although this might be explained by a lack of power in the MS-ON group, it is important to keep in mind that different underlying pathological mechanism may play a role. In MS-NON patients, 


\section{CHAPTER 6}

thinning of the RNFL may reflect axonal damage caused by retrograde trans-synaptic retinal ganglion cell (RGC) degeneration due to MS lesions within the posterior optic pathways (32), while RNFL thinning in MS-ON patients results from damage by local inflammation. Recently, inflammation has been described to have beneficial effects within the CNS, in particular for neurodegeneration (reviewed in (33). Therefore, it could be speculated that the anti-inflammatory action of vitamin D may result is less remyelination in the optic tract, resulting in thinning of the RNFL. Alternatively, axonal loss in the RNFL can be caused by neurodegeneration independently of inflammation (34). Therefore, considering the anti-inflammatory effect of vitamin D (reviewed in (10)) and visual outcomes, studying the association between vitamin D status during acute $\mathrm{ON}$ may therefore be of interest.

The findings in this study have several limitations. Firstly, this study was a pilot study, therefore the cohort size is rather small. The lack of a correlation between vitamin D status and functional visual outcome measures might be the result of insufficient power. However, the number of patients was sufficient to demonstrate a correlation between RNFL thickness and vitamin D status. Additionally, since this is the first study in MS addressing this correlation, this study provides directions for future inclusion numbers. Secondly, these findings were based on cross-sectional data, making it impossible to infer causality from the association found between vitamin D status and RNFL thickness. Longitudinal studies might provide more insight into the causality from this association. Lastly, the optimal dose/concentration at which vitamin D has an effect at immunological or neuroprotective level in MS is not known. It has been suggested by several researchers that higher levels of $25(\mathrm{OH}) \mathrm{D}$ are necessary in order to obtain benefit at immunological level (35), which may also hold for local (neuroprotective) effects of vitamin D, e.g. the eyes.

Despite these limitations, we identified a correlation between vitamin $D$ status and RNFL thickness in MS. It is therefore critical, that high dose vitamin D supplementation trials in MS, also include outcome measures of neurodegeneration. In addition, future trials should include functional visual outcome measures to exclude a lack of effect on ocular functioning.

\section{Acknowledgements}

The authors thank MS nurses Tiny Kempkens, Bertine Timmermans, Sandra Liedekerken, Maartje Bruynen, Ingrid Mevissen (Orbis Medical Center, Sittard, The Netherlands), Monique Booy and Veronique van Oers (Amphia Hospital, Breda, the Netherlands) for their help with patient recruitement and follow-up, optometrist and orthoptist Dagmar Poelma (Orbis Medical Center, Sittard, the Netherlands) and refractionist John van der Veerdonk (Amphia Hospital, Breda, the Netherlands) for their skilled technical assistance with the optical coherence tomography assays.

This study was funded by an unrestricted grant from TEVA. 


\section{References}

1. Compston A, Coles A. Multiple sclerosis. Lancet. 2008 Oct 25;372(9648):1502-17.

2. Rudick RA, Miller D, Clough JD, et al. Quality of life in multiple sclerosis. Comparison with inflammatory bowel disease and rheumatoid arthritis. Arch Neurol. 1992 Dec;49(12):1237-42.

3. The Optic Neuritis Study Group. Multiple sclerosis risk after optic neuritis: final optic neuritis treatment trial follow-up. Arch Neurol. 2008 Jun;65(6):727-32.

4. Arnold AC. Evolving management of optic neuritis and multiple sclerosis. Am J Ophthalmol. [Review]. 2005 Jun;139(6):1101-8.

5. Balcer L, Baier ML, Pelak VS, et al. New low-contrast vision charts: reliability and test characteristics in patients with multiple sclerosis. Mult Scler. [Clinical Trial Research Support, Non-U.S. Gov't Research Support, U.S. Gov't, P.H.S.]. 2000 Jun;6(3):163-71.

6. Cutolo $\mathrm{M}$, Otsa $\mathrm{K}$, Paolino $\mathrm{S}$, et al. Vitamin D involvement in rheumatoid arthritis and systemic lupus erythaematosus. Ann Rheum Dis. 2009 Mar;68(3):446-7.

7. Gatenby PA, Lucas RM, Engelsen $O$, et al. Antineutrophil cytoplasmic antibody-associated vasculitides: could geographic patterns be explained by ambient ultraviolet radiation? Arthritis Rheum. 2009 Oct 15;61(10):1417-24.

8. Hypponen E, Laara E, Reunanen A, et al. Intake of vitamin D and risk of type 1 diabetes: a birth-cohort study. Lancet. 2001 Nov 3;358(9292):1500-3.

9. Kamen DL, Cooper GS, Bouali $\mathrm{H}$, et al. Vitamin D deficiency in systemic lupus erythematosus. Autoimmun Rev. 2006 Feb;5(2):114-7.

10. Peelen E, Knippenberg S, Muris $A H$, et al. Effects of vitamin D on the peripheral adaptive immune system: a review. Autoimmun Rev. 2011 Oct;10(12):733-43.

11. Weinstock-Guttman B, Zivadinov R, Qu J, et al. Vitamin D metabolites are associated with clinical and MRI outcomes in multiple sclerosis patients. J Neurol Neurosurg Psychiatry. 2011 Feb;82(2):189-95.

12. Simpson S, Jr., Taylor B, Blizzard L, et al. Higher 25-hydroxyvitamin D is associated with lower relapse risk in multiple sclerosis. Ann Neurol. [Research Support, Non-U.S. Gov't]. 2010 Aug;68(2):193-203.

13. Smolders J, Menheere $P$, Kessels A, et al. Association of vitamin D metabolite levels with relapse rate and disability in multiple sclerosis. Mult Scler. 2008 Nov;14(9):1220-4.

14. Polman $\mathrm{CH}$, Reingold SC, Banwell B, et al. Diagnostic criteria for multiple sclerosis: 2010 revisions to the McDonald criteria. Ann Neurol. 2011 Feb;69(2):292-302.

15. Holladay JT. Visual acuity measurements. J Cataract Refract Surg. 2004 Feb;30(2):287-90.

16. Dain SJ. Clinical colour vision tests. Clin Exp Optom. 2004 Jul;87(4-5):276-93.

17. Simpson S, Jr., Taylor B, Blizzard L, et al. Higher 25-hydroxyvitamin D is associated with lower relapse risk in multiple sclerosis. Ann Neurol. 2010 Aug;68(2):193-203.

18. Millen AE, Voland R, Sondel SA, et al. Vitamin D status and early age-related macular degeneration in postmenopausal women. Arch Ophthalmol. 2011 Apr;129(4):481-9.

19. Resnikoff S, Pascolini D, Etya'ale D, et al. Global data on visual impairment in the year 2002. Bull World Health Organ. 2004 Nov;82(11):844-51.

20. Hageman GS, Luthert PJ, Victor Chong NH, et al. An integrated hypothesis that considers drusen as biomarkers of immune-mediated processes at the RPE-Bruch's membrane interface in aging and agerelated macular degeneration. Prog Retin Eye Res. 2001 Nov;20(6):705-32.

21. Tian $A Y$, Zhang RW, Shi XG, et al. Alteration of $T$ helper cell subsets in the optic nerve of experimental autoimmune encephalomyelitis. Int J Mol Med. 2010 Jun;25(6):869-74.

22. Bidmon HJ, Stumpf WE. 1,25-Dihydroxyvitamin D3 binding sites in the eye and associated tissues of the green lizard Anolis carolinensis. Histochem J. 1995 Jul;27(7):516-23.

23. Craig TA, Sommer S, Sussman $C R$, et al. Expression and regulation of the vitamin $D$ receptor in the zebrafish, Danio rerio. J Bone Miner Res. 2008 Sep;23(9):1486-96. 


\section{CHAPTER 6}

24. Choi D, Appukuttan B, Binek SJ, et al. Prediction of Cis-Regulatory Elements Controlling Genes Differentially Expressed by Retinal and Choroidal Vascular Endothelial Cells. J Ocul Biol Dis Infor. 2008;1(1):37-45

25. Knapp AA. The eye as a guide to latent nutritional deficiency diseases; a clinical study of ocular diseases at an advanced base hospital in the Southwest Pacific. Bull N Y Acad Med. 1946 Apr;22:217-22.

26. Beauchet $O$, Annweiler C, Verghese J, et al. Biology of gait control: vitamin D involvement. Neurology. [Comment Research Support, Non-U.S. Gov't]. 2011 May 10;76(19):1617-22.

27. Barkhof F, Calabresi PA, Miller DH, et al. Imaging outcomes for neuroprotection and repair in multiple sclerosis trials. Nat Rev Neurol. 2009 May;5(5):256-66.

28. Gordon-Lipkin E, Chodkowski B, Reich DS, et al. Retinal nerve fiber layer is associated with brain atrophy in multiple sclerosis. Neurology. 2007 Oct 16;69(16):1603-9.

29. Grazioli E, Zivadinov R, Weinstock-Guttman B, et al. Retinal nerve fiber layer thickness is associated with brain MRI outcomes in multiple sclerosis. J Neurol Sci. 2008 May 15;268(1-2):12-7.

30. Siger M, Dziegielewski K, Jasek L, et al. Optical coherence tomography in multiple sclerosis: thickness of the retinal nerve fiber layer as a potential measure of axonal loss and brain atrophy. J Neurol. 2008 Oct;255(10):1555-60.

31. Smolders J, Moen SM, Damoiseaux J, et al. Vitamin D in the healthy and inflamed central nervous system: access and function. J Neurol Sci. 2011 Dec 15;311(1-2):37-43.

32. Jindahra P, Petrie A, Plant GT. Retrograde trans-synaptic retinal ganglion cell loss identified by optical coherence tomography. Brain. 2009 Mar;132(Pt 3):628-34.

33. Wee Yong V. Inflammation in neurological disorders: a help or a hindrance? Neuroscientist. 2010 Aug;16(4):408-20.

34. Lassmann $\mathrm{H}$, van Horssen J. The molecular basis of neurodegeneration in multiple sclerosis. FEBS Lett. 2011 Dec 1;585(23):3715-23.

35. Vieth R. What is the optimal vitamin D status for health? Prog Biophys Mol Biol. 2006 Sep;92(1):26-32. 


\section{Chapter 7}

\section{Poor vitamin D status is correlated with}

depression, but not fatigue in multiple sclerosis 


\section{CHAPTER 7}

\section{Abstract}

Background: Depressive symptoms and fatigue are frequent and disabling symptoms of multiple sclerosis (MS). Depression and fatigue have been associated with a poor vitamin D status, and a poor vitamin D status is often found in MS.

Aim: Assess whether vitamin D status contributes to depressive symptoms and fatigue in MS.

Methods: Patients with MS that participated in previous studies in which depression and fatigue were assessed and of whom serum 25-hydroxyvitamin D (25(OH)D) levels were available within a timeframe of less than one half-life of 25(OH)D were included. Depression and fatigue were assessed with the Hospital Anxiety and Depression Scale and the Multidimensional Fatigue Inventory.

Results: Fifty-nine patients were included. Mean scores of fatigue and depression were 14.6 (SD 4.2) and 6.2 (SD 4.4), respectively. The mean vitamin D status was 62.3 $\mathrm{nm}$ (SD 27.8). Vitamin $D$ status correlated negatively with depression $(r=0.326, \mathrm{P}=$ $0.006)$. No significant correlation was found between vitamin $D$ status and fatigue. In a multiple regression model, vitamin $D$ status was not a significant contributor to depression, after controlling for age Expanded Disability Status Scale score and fatigue ( $P$ $=0.078$ ). Alternatively, depression and fatigue did not contribute to vitamin D status.

Discussion: This study shows a negative correlation between vitamin D status and depressive symptoms in patients with MS. Although multiple confounders exist, we observed an indication that vitamin D status might contribute to the presence of depressive symptoms in MS. Therefore, further studies on vitamin D in MS should include depressive symptoms as outcome measures to confirm these findings. 


\section{Introduction}

Multiple sclerosis (MS) is an inflammatory disease of the central nervous system (CNS) and is the most common non-traumatic cause of neurological deficits in young and middle-aged adults [1]. Although the exact pathogenesis of MS still remains obscure, a growing body of evidence suggests an important role for a poor vitamin D status [2]. Vitamin $D$ is acquired via dietary intake, but the predominant source of vitamin $D$ is exposure of the skin to sunlight. The most abundant and stable metabolite of vitamin $D$ in the circulation is 25 -hydroxyvitamin $D(25(\mathrm{OH}) \mathrm{D})$, and this metabolite has been accepted to describe vitamin $D$ status best. $A$ limited amount of sun exposure and poor circulating levels of 25(OH)D during childhood and adolescence have been associated with an increased risk of developing MS [3]. MS disability as expressed by Expanded Disability Status Scale (EDSS) score shows an inverse correlation with vitamin D status, and a higher vitamin $D$ status has been associated with a higher odds on remaining relapse free [4]. Although the exact mechanism by which vitamin D might influence the disease process of MS is still obscure, its immune-modulating potential is the most likely candidate $[5,6]$. One of the most common and most disabling symptoms in patients with MS is fatigue. Fatigue is reported by $92 \%$ of patients with MS [7]. Depression is also common in MS. With a lifetime prevalence of $50 \%$, depression is the most common psychiatric disorder in MS [8]. Depressive symptoms and complaints of fatigue often occur simultaneously. Little is known about underlying mechanisms of fatigue and depression in MS, although both biological and psychological factors are thought to contribute [9]. MS-related fatigue for example, is only weakly associated with disease duration or level of physical disability measured by the EDSS score [10]. Interestingly, a poor vitamin $\mathrm{D}$ status has been associated with depressive symptoms in both healthy and clinical populations [11-13], as well as with fatigue [14]. Additionally, a beneficial effect of vitamin $D$ supplementation on depressive symptoms has been found [15]. At present, the relationship between vitamin D status and complaints of depression and fatigue in MS remains unexplored. The aim of this study is to assess whether vitamin $\mathrm{D}$ status contributes to the presence of depressive symptoms and fatigue in MS.

\section{Methods}

Outpatients with MS visiting the Department of Neurology of the Maastricht University Medical Centre (MUMC) in the period 2005-2007, who participated in two previous studies on fatigue and depression, were eligible for inclusion [16, 17]. The medical ethics committee of the MUMC approved both projects, and all patients gave their written informed consent for both studies. From these previous studies, data on fatigue, depression, age, sex, disease subtype and disease severity were available for 343 


\section{CHAPTER 7}

patients. Participants had not used corticosteroids for $\geq 4$ weeks and were relapse free for $\geq 4$ weeks prior to assessment. The EDSS score was assessed by an experienced neurologist. To measure depression, the subscale depression of the well-validated Hospital Anxiety and Depression Scale (HADS) was used [18]. The depression scale results in depression scores ranging from 0 to 21, with higher scores indicating higher intensity. Scores of 8 or higher indicate that patients with MS are likely to have a depression. Fatigue was measured with the subscale physical fatigue of the Multidimensional Fatigue Inventory (MFI), a reliable and valid 20-item self-report instrument [19]. The physical fatigue subscale consists of four items referring to aspects of physical fatigue during the past few days. Scores can range between 4 and 20, with higher scores reflecting more fatigue. Available vitamin $D$ statuses of the participants, reflected by serum 25(OH)D levels, were collected from the patient files at the MUMC. Serum 25(OH)D levels were determined as described before [4]. The cut-off point regarding time between serum sampling and neuropsychological testing was set on 1 half-life of 25(OH)D. Three months has been proposed as half-life of 25(OH)D [20]. SPSS software (version 17.0; SPSS Inc., Chicago, IL, USA) was used for statistical analysis. All data were checked for normality. Variables are provided as mean with the corresponding standard deviation (SD). Group differences with regard to the included cohort $(n=59)$ and the excluded cohort $(n=284)$ were analysed by chi-square analyses (sex and disease subtype) and independent sample Student t-test. Pearson correlation coefficients were calculated to examine the relationships between all variables. Next, hierarchical regression analyses were conducted by an entry method with physical fatigue, depression and vitamin $D$ status as outcome measures. First, age and disease severity were entered as control variables. Depression, physical fatigue and vitamin D status were entered stepwise as independent variables to explore the contribution of each variable on depression, physical fatigue and vitamin $\mathrm{D}$ status. The assumptions of regression analysis, multicollinearity, homoscedasticity, normal distribution of the residuals and absence of influential outliers were checked for all models. P values $<0.05$ were considered as significant.

\section{Results}

\section{Population}

HADS depression score and MFI physical fatigue score were available for 343 patients. Although a vitamin $\mathrm{D}$ status was found for 170 of the 343 patients, only 59 patients could be included with a serum 25(OH)D measurement within 1 half-life of 25(OH)D around the assessment of fatigue and depression The demographic and clinical characteristics are shown in Table 1. Patients with MS quantified their fatigue with a mean score of 14.6 (SD 4.2). A mean HADS depression score of 6.2 (SD 4.4) was found. Twenty-two (37\%) patients had a HADS score exceeding the threshold score of 8 for a possi- 
ble depression. The mean 25(OH)D level in the total patient population $(n=59)$ was $62.3 \mathrm{~nm}$ (SD 27.8), with a range of 18-157 nm. Forty-three (73\%) patients had a vitamin $D$ status lower than $75 \mathrm{~nm}$, the proposed threshold level for an optimal calcium metabolism [21]. The correlation between these main outcome measures was assessed.

Table 1. Demographic and clinical patients characteristics.

\begin{tabular}{|c|c|c|c|c|c|}
\hline & $N=59$ & & $N=343$ & & \\
\hline & Mean (SD)/\% & Range & Mean (SD)/\% & Range & $P$ \\
\hline Sex & & & & & 0.96 \\
\hline Male & $27 \%$ & & $27 \%$ & & \\
\hline Female & $73 \%$ & & $73 \%$ & & \\
\hline Age (years) & $44.2(9.2)$ & $23.8-59.8$ & $46.7(11.2)$ & $21.1-79.9$ & 0.06 \\
\hline EDSS score & $3.6(2.1)$ & $0.0-7.5$ & $3.9(2.2)$ & $0.0-7.0$ & 0.22 \\
\hline Disease duration (years) & $5.7(6.8)$ & $0.1-35.1$ & $7.9(7.6)$ & $0.1-53.7$ & 0.02 \\
\hline MS phenotype & & & & & 0.23 \\
\hline RRMS & $59.3 \%$ & & $55.4 \%$ & & \\
\hline SPMS & $24.5 \%$ & & $21.0 \%$ & & \\
\hline PPMS & $15.3 \%$ & & $23.6 \%$ & & \\
\hline HADS & $6.2(4.4)$ & $0-19$ & $5.9(4.1)$ & $0-21$ & 0.54 \\
\hline MFI (physical fatigue) & $14.6(4.2)$ & $5-20$ & $14.4(4.2)$ & $4-20$ & 0.73 \\
\hline
\end{tabular}

EDSS = Expanded Disability Status Scale; RRMS = Relapsing Remitting Multiple Sclerosis; SPMS= Secondary Progressive Multiple Sclerosis; PPMS= Primary Progressive Multiple Sclerosis; HADS = Hospital Anxiety and Depression Scale; MFI= Multidimensional Fatigue Inventory.

Depression correlates with vitamin D status in MS

Correlations between all relevant variables are shown in Table 2. Vitamin D status correlated negatively with depression $(r=0.326, P=0.006)$. The correlation of $25(\mathrm{OH}(\mathrm{D})$ with physical fatigue did not reach significance $(r=0.195, \mathrm{P}=0.069)$. There were no effects of either season or use of Beta Interferon on HADS depression score (data not shown). To further explore the contributing value of 25(OH)D on depression and physical fatigue, linear regression analyses were performed. 


\section{CHAPTER 7}

Table 2. Pearson correlations of dependent and independent variables

\begin{tabular}{llll}
\hline & HADS & MFI (physical fatigue) & $25(\mathrm{OH}) \mathrm{D}$ \\
\hline Age & $0.164^{* *}$ & $0.249 * *$ & $-0.336^{* *}$ \\
EDSS score & $0.249 * *$ & $0.458^{* *}$ & -0.198 \\
$25(\mathrm{OH}) \mathrm{D}$ & $-0.326^{* *}$ & -0.195 & - \\
MFI (physical fatigue) & $0.479 * *$ & - & -
\end{tabular}

EDSS= Expanded Disability Status Scale; HADS= Hospital Anxiety and Depression Scale; MFI= Multidimensional Fatigue Inventory.

$* \mathrm{p}<0.05, * * \mathrm{p}<0.01$

In a multiple regression model, vitamin D status does not contribute to depression significantly

The results of the linear regression analyses are shown in Table 3. Vitamin D status did not contribute significantly to physical fatigue in patients with MS, after controlling for age, EDSS and depression. In a multiple regression model, vitamin D status was not a significant contributor to depression, after controlling for age, EDSS score and fatigue $(\beta=-0.229 P=0.078)(P=0.078)$. Given the correlation found between vitamin $D$ status and depression, we assessed the alternative hypothesis that depression and fatigue may predict the vitamin $D$ status. Both depression and physical fatigue did not contribute to vitamin D status in patients with MS in the linear regression analyses (Table 3).

Table 3. Linear regression models for variables contributing to depression, physical fatigue and vitamin D status

\begin{tabular}{lllllll}
\hline & HADS & \multicolumn{3}{l}{ MFI (physical fatigue) } & \multicolumn{2}{l}{ 25(OH)D } \\
\hline & $\beta$ & R2 & $\beta$ & R2 & $\beta$ & R2 \\
Age & 0.071 & 0.053 & 0.010 & 0.046 & $-0.263^{*}$ & 0.113 \\
EDSS score & 0.041 & 0.103 & $0.435^{* *}$ & 0.277 & 0.046 & 0.124 \\
HADS & - & - & $0.283^{*}$ & 0.351 & -0.046 & 0.124 \\
MFI (physical fatigue) & $0.332^{*}$ & 0.194 & - & - & -0.013 & 0.180 \\
25(OH)D & -0.229 & 0.239 & -0.011 & 0.351 & - & - \\
\hline
\end{tabular}

EDSS = Expanded Disability Status Scale; HADS= Hospital Anxiety and Depression Scale; MFI= multidimensional Fatigue Inventory.

${ }^{*} \mathrm{p}<0.05,{ }^{* *} \mathrm{p}<0.01$ 


\section{Discussion}

A poor vitamin D status is often found in MS and has been associated with the presence of depressive symptoms and fatigue in several populations [13-15]. In the present study, we found no correlation between physical fatigue and vitamin D status, but we did demonstrate that vitamin D status in patients with MS correlates with their depression scores. Although multiple confounders exist, we observed an indication that vitamin D status might contribute to the presence of depressive symptoms in MS. Moreover, despite the fact that it is conceivable that MS patients suffering from depressive symptoms have less sun exposure, vitamin D status did not depend on the level of depressive symptoms in the regression model. Therefore, future studies on vitamin D in MS should include depressive symptoms as an outcome measure, preferably randomized controlled trials, to confirm these findings. Several studies [15, 22] suggest a role of vitamin $D$ in the presence of depressive symptoms. In patients with Alzheimer disease and healthy controls, a poor vitamin D status has been associated with the presence of depressive symptoms [23]. In obese subjects, not only higher depression scores were found in subjects with serum 25(OH)D levels $<40 \mathrm{~nm}$, but these scores also decreased after supplementation of 20,000-40,000 IU /w vitamin D3 for 1 year [15]. A randomized trial on vitamin D supplementation in doses of either 600 or $4000 \mathrm{IU} /$ day showed a greater improvement of general well-being in outpatients with thyroid disease treated with the higher dose [22]. These studies support the idea that a poor vitamin D status contributes to depressive symptoms and that vitamin D supplementation can reduce these symptoms. The mechanism by which this therapeutic effect could be mediated remains uncertain. Both biological and psychological factors are thought to play a role in the aetiology of depression in MS [24, 25]. Non-MS patients with major depression have higher circulating levels of the pro-inflammatory cytokine interferon- $\gamma$ (IFN- $\gamma$ ) [26]. Additionally, anti-depressant treatments had antiinflammatory effects in these cohorts by decreasing IFN-c and by increasing interleukin (IL)-10, an important regulatory cytokine [27]. Interestingly, a relatively lower expression of IFN-c has been found in T cells of MS patients with higher serum 25(OH)D levels [6], and exposure of T cells of patients with MS to vitamin D increased the production of anti-inflammatory cytokines as IL-10 [5]. Alternatively, vitamin D has been reported to have biological functions within the CNS. Holmøy et al. [28] showed that 25(OH)D is present in the CNS of patients with MS and that its levels correlate positively with serum 25(OH)D levels. Therefore, a poor systemic vitamin D status may also impair poorly defined local functions of vitamin D in the CNS of patients with MS. We found no correlation between vitamin D and fatigue in our study cohort. This is in contrast to previous findings in other populations. For instance in patients with systemic lupus erythematosus, vitamin D3 supplementation had a beneficial effect on fatigue [14]. On the other hand, vitamin D3 supplementation in women with breast cancer did not reduce fatigue significantly [29]. However, these populations are difficult to compare, 


\section{CHAPTER 7}

as different biological and psychological mechanisms may underlie fatigue in each specific condition [9].

The findings in the present study have several limitations. First, the fluctuating nature of both MS activity and vitamin D status makes it preferable to perform all assessments on the same day. In addition, more conservative estimations of the halflife of $25(\mathrm{OH}) \mathrm{D}$ have been made [30]. However, the seasonal variation of $25(\mathrm{OH}) \mathrm{D}$ is marginal when compared to the variation in 25(OH)D levels found in our cohort [31]. Therefore, the provided vitamin $D$ data give at least a rough estimation of the vitamin $D$ status at the time of assessment of depression and fatigue. Second, we used a crosssectional design, and vitamin $\mathrm{D}$ levels were collected retrospectively. This, in combination with the rather small study cohort, might confound our results. Despite the limitations of the study, we identified a correlation between vitamin $D$ status and depressive symptoms in patients with MS. As depressive symptoms in MS are frequent and disabling [7], the present results support the inclusion of depression as outcome measure in future trials on vitamin D supplementation in MS. 


\section{References}

1. Compston, A. and A. Coles, Multiple sclerosis. Lancet, 2008. 372(9648): p. 1502-17.

2. Smolders, J., et al., Vitamin D as an immune modulator in multiple sclerosis, a review. J Neuroimmunol, 2008. 194(1-2): p. 7-17.

3. Ascherio, A., K.L. Munger, and K.C. Simon, Vitamin D and multiple sclerosis. Lancet Neurol, 2010. 9(6): p. 599-612.

4. Smolders, J., et al., Association of vitamin D metabolite levels with relapse rate and disability in multiple sclerosis. Mult Scler, 2008. 14(9): p. 1220-4.

5. Correale, J., M.C. Ysrraelit, and M.I. Gaitan, Immunomodulatory effects of Vitamin D in multiple sclerosis. Brain, 2009. 132(Pt 5): p. 1146-60.

6. Smolders, J., et al., Vitamin D status is positively correlated with regulatory $\mathrm{T}$ cell function in patients with multiple sclerosis. PLoS One, 2009. 4(8): p. e6635.

7. Branas, P., et al., Treatments for fatigue in multiple sclerosis: a rapid and systematic review. Health Technol Assess, 2000. 4(27): p. 1-61.

8. Patten, S.B., et al., Major depression in multiple sclerosis: a population-based perspective. Neurology, 2003. 61(11): p. 1524-7.

9. Bol, Y., et al., The psychology of fatigue in patients with multiple sclerosis: a review. J Psychosom Res, 2009. 66(1): p. 3-11.

10. Krupp, L.B., et al., Fatigue in multiple sclerosis. Arch Neurol, 1988. 45(4): p. 435-7.

11. Bertone-Johnson, E.R., Vitamin $D$ and the occurrence of depression: causal association or circumstantial evidence? Nutr Rev, 2009. 67(8): p. 481-92.

12. Bossola, M., et al., Correlates of symptoms of depression and anxiety in chronic hemodialysis patients. Gen Hosp Psychiatry, 2010. 32(2): p. 125-31.

13. Hoogendijk, W.J., et al., Depression is associated with decreased 25-hydroxyvitamin D and increased parathyroid hormone levels in older adults. Arch Gen Psychiatry, 2008. 65(5): p. 508-12.

14. Ruiz-Irastorza, G., et al., Vitamin D deficiency in systemic lupus erythematosus: prevalence, predictors and clinical consequences. Rheumatology (Oxford), 2008. 47(6): p. 920-3.

15. Jorde, R., et al., Effects of vitamin D supplementation on symptoms of depression in overweight and obese subjects: randomized double blind trial. J Intern Med, 2008. 264(6): p. 599-609.

16. Bol, Y., et al., The impact of fatigue on cognitive functioning in patients with multiple sclerosis. Clin Rehabil, 2010. 24(9): p. 854-62.

17. Bol, Y., et al., Fatigue and physical disability in patients with multiple sclerosis: a structural equation modeling approach. J Behav Med, 2010. 33(5): p. 355-63.

18. Spinhoven, P., et al., A validation study of the Hospital Anxiety and Depression Scale (HADS) in different groups of Dutch subjects. Psychol Med, 1997. 27(2): p. 363-70

19. Smets, E.M., et al., The Multidimensional Fatigue Inventory (MFI) psychometric qualities of an instrument to assess fatigue. J Psychosom Res, 1995. 39(3): p. 315-25.

20. Mawer, E.B., G.A. Lumb, and S.W. Stanbury, Long biological half-life of vitamin D3 and its polar metabolites in human serum. Nature, 1969. 222(5192): p. 482-3.

21. Dawson-Hughes, B., et al., Estimates of optimal vitamin D status. Osteoporos Int, 2005. 16(7): p. 713-6.

22. Vieth, R., et al., Randomized comparison of the effects of the vitamin D3 adequate intake versus 100 mcg (4000 IU) per day on biochemical responses and the wellbeing of patients. Nutr J, 2004. 3: p. 8.

23. Wilkins, C.H., et al., Vitamin D deficiency is associated with low mood and worse cognitive performance in older adults. Am J Geriatr Psychiatry, 2006. 14(12): p. 1032-40.

24. Lynch, S.G., D.C. Kroencke, and D.R. Denney, The relationship between disability and depression in multiple sclerosis: the role of uncertainty, coping, and hope. Mult Scler, 2001. 7(6): p. 411-6. 


\section{CHAPTER 7}

25. Patten, S.B. and L.M. Metz, Fatigue and depression in multiple sclerosis. Can J Psychiatry, 2000. 45(1): p. 84-5.

26. Maes, M., et al., The inflammatory \& neurodegenerative (I\&ND) hypothesis of depression: leads for future research and new drug developments in depression. Metab Brain Dis, 2009. 24(1): p. 27-53.

27. Kubera, M., et al., Anti-Inflammatory effects of antidepressants through suppression of the interferongamma/interleukin-10 production ratio. J Clin Psychopharmacol, 2001. 21(2): p. 199-206.

28. Holmoy, T., et al., 25-hydroxyvitamin D in cerebrospinal fluid during relapse and remission of multiple sclerosis. Mult Scler, 2009. 15(11): p. 1280-5

29. Khan, Q.J., et al., Effect of vitamin D supplementation on serum 25-hydroxy vitamin D levels, joint pain, and fatigue in women starting adjuvant letrozole treatment for breast cancer. Breast Cancer Res Treat, 2010. 119(1): p. 111-8.

30. Smith, J.E. and D.S. Goodman, The turnover and transport of vitamin D and of a polar metabolite with the properties of 25-hydroxycholecalciferol in human plasma. J Clin Invest, 1971. 50(10): p. 2159-67.

31. Brock, K., et al., Low vitamin D status is associated with physical inactivity, obesity and low vitamin D intake in a large US sample of healthy middle-aged men and women. J Steroid Biochem Mol Biol, 2010. 121(1-2): p. 462-6. 


\section{Chapter 8}

\section{Higher levels of reported sun exposure, and not vitamin D status, are associated with less depressive symptoms and fatigue in MS}

Adapted from: S. Knippenberg, J Damoiseaux, Y Bol, R Hupperts, BV Taylor, A-L Ponsonby, T Dwyer, L Blizzard, Simpson S Jr, IAF van der Mei. Higher levels of reported sun exposure, and not vitamin D status, are associated with less depressive symptoms and fatigue in MS. Submitted. 


\section{CHAPTER 8}

\section{Abstract}

Objective: Insufficient sun exposure and vitamin D deficiency have both been associated with increased risk of multiple sclerosis (MS). Depression, anxiety, fatigue and cognitive impairment are prevalent and disabling symptoms in MS. Our objective was to examine the associations between personal sun exposure and serum 25hydroxyvitamin $\mathrm{D}(25(\mathrm{OH}) \mathrm{D})$, and depression, anxiety, fatigue and cognition.

Methods: $198 \mathrm{MS}$ participants were followed prospectively for an average of 2.3 years. Assessments of serum 25(OH)D, sun exposure, depression, anxiety, fatigue were done biannually; cognition was assessed annually.

Results: Personal reported sun exposure was inversely associated with depression scores $(\beta-0.26(95 \% \mathrm{Cl}-0.40,-0.12)) ; \mathrm{p} \leq 0.001)$ and fatigue scores $(\beta-0.65(95 \% \mathrm{Cl}-1.23$, $-0.07) ; p=0.028)$. Only high levels of $25(\mathrm{OH}) \mathrm{D}(>80 \mathrm{nmol} / \mathrm{L})$ were inversely associated depression scores $(\beta-0.64(95 \% \mathrm{Cl}-1.15,-0.13)) ; \mathrm{p}=0.015)$, but this was not significant after adjustment for reported sun exposure. No associations were seen between reported sun exposure or serum 25(OH)D levels and anxiety or cognition scores.

Conclusion: We found that higher levels reported sun exposure, rather than 25(OH)D levels, were associated with less depressive symptoms and levels of fatigue. The role of UV or light therapy will need to be evaluated in randomized controlled trials to confirm an effect on these symptoms in MS. 


\section{Introduction}

Multiple sclerosis (MS) is a chronic inflammatory disease of the central nervous system (CNS), where both genetic and environmental factors are involved in its pathogenesis (1). MS frequency increases with increasing latitude, which might be explained by the corresponding decrease in ambient ultraviolet radiation (UVR) intensity (2). The mechanism underlying this association may be the immunomodulatory effect of UVR (3). Vitamin $D$ has been proposed to be the major mediator in the protective effect of UVR since vitamin $D$ is produced under the influence of sunlight, with dietary intake only contributing a small fraction (4). The active hormone 1,25-dihydroxyvitamin D $\left(1,25(\mathrm{OH})_{2} \mathrm{D}\right)$ mediates a range of effects in the body, including effects on the immune system and CNS $(5,6)$. The major circulating metabolite of vitamin $D$ is 25 hydroxyvitamin $\mathrm{D}(25(\mathrm{OH}) \mathrm{D})$, which is accepted to describe vitamin $\mathrm{D}$ status best (7). There is good evidence that decreased sun exposure, low dietary intake of vitamin $D$ and low circulating levels of 25(OH)D are inversely associated with risk of MS onset (810) and evidence that low 25(OH)D is associated with clinical course (11-13).

The associations between sun exposure or $25(\mathrm{OH}) \mathrm{D}$ levels and common MS symptoms such as depression, anxiety, fatigue and cognitive impairment have received relatively little attention. Fatigue is one of the most common and most disabling symptoms in MS, with a prevalence up to $92 \%$ (14). The prevalence of depression among people with MS is about $40 \%$ (15). Similarly the prevalence of anxiety and cognitive impairment ranges from $20-40 \%$ (15) and $43-70 \%$ respectively (16). Previous studies assessing the relationship between depressive symptoms, fatigue and cognitive impairment and $25(\mathrm{OH}) \mathrm{D}$ levels in healthy and diseased populations show conflicting results (17-22). Although some studies reported an association, it is unknown whether fatigue and neuropsychiatric symptoms were the cause or result of the observed 25(OH)D status, or merely linked to sun exposure. Therefore, the aim of this study was to examine whether reported sun exposure and / or low 25(OH)D levels are associated with higher levels of depressive and anxiety symptoms, fatigue and lower cognitive performance in a prospective cohort with clinically definite MS.

\section{Methods}

\section{Subjects}

All subjects were participants of the Southern Tasmanian Multiple Sclerosis Longitudinal Study (23). Ethical approval was received from the Southern Tasmania Human Research Ethics Committee. All participants provided informed consent. The study methodology has been previously described (23). MS patients (2001 McDonald criteria(24)) were reviewed each summer and winter between summer 2002 and summer 2005 with a mean follow-up of 2.5 years. A total of 203 MS patients were 


\section{CHAPTER 8}

recruited; four patients did not have clinically definite MS and 1 patient completed pilot study only, leaving 198 participants for analysis who were all Caucasian.

\section{Study outcome measures}

At each review, depressive symptoms and anxiety were measured with the Hospital Anxiety and Depression Scale (HADS) was used. HADS is designed to screen physically ill patients (25) and reliability and validity have been demonstrated in MS (26). The HADS consists of two subscales (HADS-A and HADS-D, respectively), each consisting of 7 items (total scores between $0-21$ ) (25). A score of $\geq 8$ in the respective subscales indicates that participants are likely to have a depressive disorder or a general anxiety disorder (26). Fatigue was measured at each review with the Fatigue Severity Scale (FSS). The FSS contains 9 items (scored from 1-7). The sum of the items divided by 9 provides the final FSS score with higher scores reflecting more fatigue (27). Prevalent fatigue was defined as FSS $\geq 5$ (28).

Cognitive performance was measured at each winter review with the threesecond Paced Auditory Serial Addition Test (PASAT-3) of the MS Functional Composite was used (29). The PASAT measures information-processing speed, working memory and sustained attention. In the PASAT- 3 single digits are presented every 3 seconds. The participant must add each presented digit to the one immediately prior to it. The final test score is the number of correct answers, with a maximum score of 60 (29).

\section{Sun exposure and 25(OH)D measurement}

At each review, participants quantified how much time they spent in the sun during weekends and holidays in the current and preceding 3-month intervals using validated questions (30). Sun exposure was categorised as: "none" $=0$, " 0 to $1 / 2 \mathrm{hr} /$ day" $=0.25$, , $1 / 2$ to $1 \mathrm{hr} /$ day"= 0.75 , " 1 to $2 \mathrm{hrs} /$ day" $=1.5$, "2 to $3 \mathrm{hrs} /$ day" $=2.5$, " 3 to $4 \mathrm{hrs} /$ day" $=3.5$, and "more than $4 \mathrm{hrs} /$ day" $=4.5 .(31)$

Serum 25(OH)D was measured at each review using a commercially available radioimmunoassay (DiaSorin, Stillwater, MN). Inter-batch reproducibility was $4.6 \%$ at 32 $\mathrm{nmol} / \mathrm{L}$ and $6.4 \%$ at $125 \mathrm{nmol} / \mathrm{L}$. All samples were stored at $-80^{\circ} \mathrm{C}$ and shielded from light. All measures were performed in sequential batches in order of blood draw following the conclusion of the study, thus all investigators were blinded for vitamin $D$ status when outcomes were measured.

\section{Other measures}

Neurological disability was assessed by the Expanded Disability Status Scale (EDSS) score at each winter review by a single research clinician. The research clinician also assessed MS course and clinical history. Height, weight and education level were measured at study entry by the study nurse. At each review, subjects were asked about their medication use, smoking, sun avoidance due to heat sensitivity, sleep (quantity, quality, number of awakenings at night), physical exercise (moderate and vigorous exercise) and use of vitamin D supplements (in analysis categorised as none, 
$>0-200 \mathrm{IU} /$ day, 201-750 IU/day). There were 122 validated relapses during the study (13).

\section{Estimating 25(OH)D levels at different time points}

Blood samples were taken biannually over an interval of three to four months. To remove variability associated with the timing of blood draw, 25(OH)D was deseasonalised as described previously (13) using a sinusoidal regression model:

$y_{t}=\beta_{0}+\beta_{1} \sin \left(\frac{2 \pi t}{365}\right)+\beta_{2} \cos \left(\frac{2 \pi t}{365}\right)$

where $y_{t}$ denotes measured serum 25(OH)D concentration, $t$ denotes the day of the year the sample was collected, and $\beta_{j}(j=0,1,2)$ are estimated regression coefficients. Using this model, deseasonalised 25(OH)D levels were predicted at the beginning of the summer or winter season, reducing much of the variation due to timing of sampling.

\section{Statistical analysis}

We used mixed-effect analysis for repeated measures to assess the relationship between $25(\mathrm{OH}) \mathrm{D}$ and sun exposure and the outcome measures. Analysis results are presented unadjusted to assess the relationships between predictive covariates and the outcome measures. Next, results are presented from models adjusted for age, sex, and other confounders. Covariates such as initial EDSS score, initial course of the disease, medication use, body mass index (BMI) and smoking were chosen after carefully examining whether these factors were confounders and not mediating factors. In addition, all PASAT scores were also adjusted for education level.

We report the results for deseasonalised 25(OH)D. Similar results were observed when we used crude 25(OH)D levels and adjusted for season (coded as summer, winter). Unless otherwise stated, all results are reported for the total sample. All statistical analyses were performed using STATA/IC software (version 10.1; StataCorp LP, College Station, TX).

Time lag analysis

Our standard analysis (adjusted results) evaluated 25(OH)D levels at each review and reported sun exposure in current season with the outcome of interest (PASAT at review, and FSS and HADS in the week preceding review). In order to evaluate causality, we shifted each measured 25(OH)D levels and reported sun exposure 6 and 12 months before and 6 and 12 months after the outcome. If the observed association was due to reverse causality, then one might expect the magnitude of effect to become stronger when predictors modelled 6 or 12 months after the outcome were used. 


\section{CHAPTER 8}

\section{Results}

\section{Participant characteristics}

Table 1 shows the characteristics of this population-based cohort. At study entry, the prevalence of depression, anxiety, and fatigue was $19.1 \%, 45.2 \%$ and $53.7 \%$, respectively. The mean number of correct answers on PASAT was 35.0 (SD 17.8). Anxiety decreased somewhat during the study $(\beta$ : $-0.29(-0.45,-0.12)$ per year, $p=0.001)$, but no significant change was observed for depression $(p=0.10)$, fatigue $(p=0.60)$ or cognitive function $(p=0.35)$, sun exposure $(p=0.46)$ or $25(\mathrm{OH}) \mathrm{D}$ levels $(p=0.33)$. We checked whether having a relapse up to 30 days prior to the assessment of the outcomes might influence the outcome measures, but this was not the case.

\section{Vitamin $D$, sun exposure and depression}

Unadjusted and adjusted deseasonalised continuous 25(OH)D levels were not associated with depression scores (Table 2). However, adjusted categorical 25(OH)D levels higher than $80 \mathrm{nmol} / \mathrm{L}$ were inversely associated (Table 3). Although there was a positive association between vitamin $D$ supplement use and depression scores ( $\beta$ : 0.49 (95\% $\mathrm{Cl} 0.10,0.89) ; p=0.014)$, adjusting for vitamin $\mathrm{D}$ supplement use did not alter the association between 25(OH)D and depression scores $(\beta$ : $-0.66(95 \% \mathrm{Cl}-1.16,-0.16)$; $p=0.009)$. The association between $25(\mathrm{OH}) \mathrm{D}$ levels did not differ by sex $(\mathrm{p}=0.16$ for interaction), disease duration ( $p=0.41$ for interaction) or initial course of the disease $(p=0.19)$.

Interestingly, higher levels of reported personal sun exposure in the current season were associated with lower depression score (Table 2). This association was not abrogated after further adjustment for physical exercise. When both continuous $25(\mathrm{OH}) \mathrm{D}$ and sun exposure were included in the model, the magnitude of the coefficient of sun exposure remained stable $(\beta:-0.26(95 \% \mathrm{Cl}-0.40,-0.11) ; p=0.001)$, while $25(\mathrm{OH}) \mathrm{D}$ remained non-significant $(\mathrm{p}=0.667)$. When both categorical $25(\mathrm{OH}) \mathrm{D}$ and sun exposure were included in the model, the magnitude of the coefficient of the highest levels of $25(\mathrm{OH}) \mathrm{D}(>80 \mathrm{nmol} / \mathrm{L})$ was reduced by $28 \%$ and became non-significant $(p=0.11)$, while the magnitude of the coefficient of sun exposure reduced only $12 \%$ and remained significant $(p=0.001)$. This suggests that the effect of sun exposure occurs largely via a mechanism that is independent of 25(OH)D. The association between sun exposure and depression scores did not differ by sex ( $p=0.65$ for interaction), disease duration ( $p=0.69$ for interaction), or initial course of the disease $(p=0.99)$. 
Table 1. Demographic and clinical characteristics of the participants of the Tasmanian MS Longitudinal Study at study entry*

\begin{tabular}{|c|c|c|}
\hline & Mean (SD) / Median (IQR) & Range \\
\hline Age(yr) & $48.2( \pm 11.4)$ & $21-77$ \\
\hline Disease duration since first symptom (yr) & $12(6-20)^{\dagger}$ & $0-58$ \\
\hline EDSS score & $3(2-5.5)^{\dagger}$ & $0-9$ \\
\hline HADS depression score & $4.5( \pm 3.2)$ & $0-14$ \\
\hline HADS anxiety score & $6.9( \pm 3.9)$ & $0-15$ \\
\hline FSS fatigue score & $4.8( \pm 1.6)$ & $1-7$ \\
\hline PASAT score (no. correct answers) & $35.0( \pm 16.5)$ & $0-60$ \\
\hline Education (yr) & $12.8(3.8)$ & $6-18$ \\
\hline \multicolumn{3}{|l|}{$25(\mathrm{OH}) \mathrm{D} \mathrm{nmol} / \mathrm{L}$} \\
\hline Summer & $65.4( \pm 25.2)$ & 18.7-132.7 \\
\hline \multirow[t]{2}{*}{ Winter } & $39.2( \pm 14.4)$ & $17.3-72.3$ \\
\hline & $\mathrm{n} / \mathrm{N}$ & $\%$ \\
\hline \multicolumn{3}{|l|}{ Sex } \\
\hline Female & $137 / 198$ & 69.2 \\
\hline Male & $61 / 198$ & 30.8 \\
\hline \multicolumn{3}{|l|}{ Initial MS course } \\
\hline RRMS & $149 / 198$ & 75.3 \\
\hline SPMS & $40 / 198$ & 20.2 \\
\hline PPMS & $9 / 198$ & 4.5 \\
\hline Initial depression (HADS depression score $\geq 8$ ) & $38 / 198$ & 19.2 \\
\hline Mild depression (HADS depression score 8-10) & $30 / 198$ & 15.2 \\
\hline Severe depression (HADS depression score 11-21) & $8 / 198$ & 4.0 \\
\hline Initial anxiety (HADS anxiety score $\geq 8$ ) & $89 / 198$ & 45.0 \\
\hline Mild anxiety (HADS anxiety score 8-10) & $54 / 198$ & 27.3 \\
\hline Severe anxiety (HADS anxiety score 11-21) & $35 / 198$ & 17.7 \\
\hline Initial fatigue (FSS score $\geq 5$ ) & 109/196 & 55.6 \\
\hline Borderline fatigue $(4.0<$ FSS $<5.0)$ & $31 / 196$ & 15.8 \\
\hline Immunomodulatory treatment & $122 / 198$ & 61.6 \\
\hline
\end{tabular}

* 25(OH)D levels are provided as a mean winter and summer value. tDue to a skewed distribution, median and interquartile range (IQR) are provided.

Using time lag analysis, compared to the adjusted results ( $\beta$ : $-0.26(-0.40,-0.12)$; $p<0.001)$, the magnitude of the coefficient of reported sun exposure fluctuated 6 months $(\beta:-0.17(-0.31,-0.02) ; p=0.026)$ and 12 months $(\beta: 0.004(-0.16,0.17) ; p=0.96)$ before depression scores as well as 6 months $(0.09(-0.08(0.26) ; p=0.29)$ and 12 months $(\beta$ : $-0.28(-0.46,-0.10) ; p=0.002)$ after depression. Thus although a prospective 


\section{CHAPTER 8}

dimension was evident for sun exposure-depression, reverse causality could not be excluded.

\section{Vitamin $D$, sun exposure and anxiety}

There were no associations between 25(OH)D levels or reported sun exposure and HADS anxiety score (Table 4), nor any association between vitamin D supplement use and HADS-anxiety $(\beta$ : $0.21(95 \% \mathrm{Cl}-0.25,0.67) ; p=0.38)$. Because anxiety scores decreased over time in this population, we examined whether $25(\mathrm{OH}) \mathrm{D}$ levels and reported sun exposure were associated with a change in anxiety; however, no associations were found.

\section{Vitamin $D$, sun exposure and fatigue}

There was no association between unadjusted or adjusted 25(OH)D levels and fatigue scores (Table 5), nor was vitamin $D$ supplement use associated with fatigue scores ( $\beta$ : $0.35(95 \% \mathrm{Cl}-1.15,1.85) ; \mathrm{p}=0.65)$. Higher reported sun exposure however, was associated with lower FSS scores. After adjustment for confounders, the association between sun exposure and fatigue score remained significantly inversely associated.

Mutually-adjusting 25(OH)D and sun exposure increased the magnitude of the coefficient of sun exposure $(\beta:-0.70(95 \% \mathrm{Cl}-1.29,-0.07) ; p=0.028)$, while $25(\mathrm{OH}) \mathrm{D}$ remained non-significant $(p=0.51)$. The association did not differ by sex $(p=0.31$ for interaction), initial EDSS score ( $p=0.58$ for interaction), initial disease duration ( $p=0.17$ for interaction) or initial course of the disease $(p=0.10)$. There was a positive association between heat sensitivity and fatigue $(\beta: 9.68$ (95\% Cl 6.41, 12.94); $p<0.001$ in our study), the magnitude of effect of the association between reported sun exposure and fatigue was less strong in people who reported heat sensitivity $(\beta:-0.29(95 \% \mathrm{Cl}-0.99$, $0.41) ; p=0.42)$ relative to those not reporting heat sensitivity $(\beta:-0.95(95 \% \mathrm{Cl}-1.80$, $0.10) ; p=0.029$ ). Adjusting for sleep (quantity, quality and awakening at night) did not alter the results (data not shown).

Compared to the adjusted results ( $\beta$ : $-0.65(-1.23,-0.07) ; p=0.028)$, the magnitude of the coefficients fluctuated 6 months $(\beta: 0.02(-0.58,0.62) ; p=0.95)$ and 12 months ( $\beta$ : $0.06(-0.62,0.73) ; p=0.87)$ before fatigue as well as 6 months $(\beta: 0.21(-0.41,0.84)$; $p=0.45)$ and 12 months $(\beta:-0.94(-1.69,-0.10) ; p=0.014)$ after fatigue score. Thus a significant prospective association was not evident and reverse causality could not be excluded.

\section{Vitamin $D$, sun exposure and cognition}

There were no associations between 25(OH)D levels or reported sun exposure and PASAT score (Table 6). Vitamin D supplement use was not associated with PASAT score ( $\beta$ : $-0.40(95 \% \mathrm{Cl}-2.74,1.94) ; p=0.74)$. In this cohort, cognitive function declined among patients with a disability $\geq 4.5$ EDSS score. Therefore, we examined whether 25(OH)D levels and reported sun exposure were associated with PASAT score among patients with a disability level $\geq 4.5$, but no association was found. 


\section{Discussion}

In this prospective longitudinal study with repeated measures in MS patients, we found that higher levels of reported sun exposure were associated with less depressive symptoms and lower levels of fatigue. We did not observe associations between continuous 25(OH)D levels and severity of fatigue or with neuropsychiatric symptoms of MS. While an inverse association between the highest levels of $25(\mathrm{OH}) \mathrm{D}(>80 \mathrm{nmol} / \mathrm{L})$ and depression scores was seen, this did not remain significant after adjustment for sun exposure. The associations with reported sun exposure remained significant after adjustment for $25(\mathrm{OH}) \mathrm{D}$ levels.

The effect of sun exposure on depression might be explained by the initiation of anti-inflammatory cytokines after UVR exposure (32). Similar to UVR exposure, antidepressant treatments have been described to increase the anti-inflammatory cytokine IL-10 (33). In addition to the immune hypothesis, decreased exposure to light could reduce risk of depression by interacting with the circadian rhythm. The exact mechanism of light on depression remains unclear, but may involve light induced suppression of pineal melatonin secretion, important in sleep/wake cycle. Interestingly, increased melatonin levels have been associated with higher depression scores in patients with long standing MS (34).

In line with the described effect of UVR exposure on the immune system and the increased levels of pro-inflammatory cytokines TNF- $\alpha$ and IFN- $\gamma$ in MS patients with fatigue (35), we observed a negative association between reported sun exposure and fatigue. In addition, light-induced melatonin suppression could also play a role in fatigue, because recently dysfunction in melatonin secretion has been suggested to explain reduced sleep efficiency in treatment naïve MS patients (36). It is known that those with higher levels of fatigue report more often heat sensitivity (27); however, when we explored the association by sun avoidance behaviour, the association between sun exposure and fatigue was less strong in those who reported heat sensitivity. This suggests that our finding may not reflect reverse causality, since this population is more likely to avoid sun if it would lead to fatigue.

We did not observe significant associations between continuous 25(OH)D levels and fatigue and neuropsychiatric symptoms of MS. However, an effect of vitamin D on depressive symptoms cannot be completely excluded, because we observed a negative association between high $25(\mathrm{OH}) \mathrm{D}$ levels (>80 nmol/L) and depressive symptoms. There are plausible theories as to how 25(OH)D might mediate its effect on depression, including a direct effect on the CNS via the vitamin D receptor or a peripheral effect on the production of anti-inflammatory cytokines such as IL-10 (6). Previous crosssectional studies and vitamin D supplementation studies exploring the association between vitamin $D$ status and these symptoms in healthy and diseased populations show conflicting results (17-22). These differences in outcomes might be explained by a large variation in inclusion numbers, different outcome assessment scales and varia- 


\section{CHAPTER 8}

tion in geographical distribution with concomitant genetic variations. Interestingly, an interaction between vitamin $D$ and genes has been suggested in MS (37). Of additional notice, in contrast to our study none of the before mentioned studies exploring the association between vitamin $D$ and fatigue and neuropsychiatric symptoms took sun exposure into account. Since the majority of vitamin $D$ is usually UVR-generated, previous studies showing a correlation with vitamin $D$ could potentially be an epiphenomenon of sun exposure. Although our results suggests a mechanism of sun largely outside the vitamin D pathway, reverse causality should also be considered as an explanation for the observed association between sun exposure and depression scores. The optimal design to confirm the association is a randomised controlled trial.

This study has the advantage of being prospective with repeated measures and having an adequate sample size. Furthermore, all outcome measures were assessed on the same day for each participant, reducing variability in these measures. We were able to use time lag modelling to demonstrate a prospective association, but could not rule out reverse causality. Another strength of this study was that many potential confounders were measured, allowing the consideration and evaluation of multiple confounders. However, no data was collected on non-MS related causes of fatigue, such as hypothyroidism or anaemia, so these factors could not be evaluated in this study. In addition, it is important to realize that we used depression and anxiety questionnaires to measure these symptoms and did not use a DSM-IV diagnosis of a depressive or anxiety disorder. In addition, PASAT mainly screens attention and working memory, while an improvement was found in particular executive functions after vitamin $D$ supplementation in older outpatients (17).

In conclusion, we observed that higher levels reported sun exposure, rather than 25(OH)D levels, were associated with less depressive symptoms and levels of fatigue, after mutually adjusting for each other. There was some evidence that 25(OH)D levels above $80 \mathrm{nmol} / \mathrm{L}$ were inversely associated with depressive symptoms, and vitamin $\mathrm{D}$ supplementation trials will have to confirm whether high levels of vitamin $D$ have the capacity to reduce these symptoms in MS. These randomised controlled trials should preferably be complemented with UV therapy or light therapy arms to definitively answer whether UV radiation or light therapy is able to reduce depression and fatigue in people with MS. In addition, basic research on the immunological and endocrine mechanisms of UV therapy or light therapy will be important to unravel the mechanism by which this putative effect occurs.

Study sponsorship or funding: The Multiple Sclerosis Longitudinal Study was funded by a grant from the National Health \& Medical Research Council of Australia (Project 333105). Additional funding support was provided by the Trish Foundation for vitamin D measures and the Tasmanian MS Society for dietary analysis. IvdM is supported by an Australian Research Council Future Fellowship. 


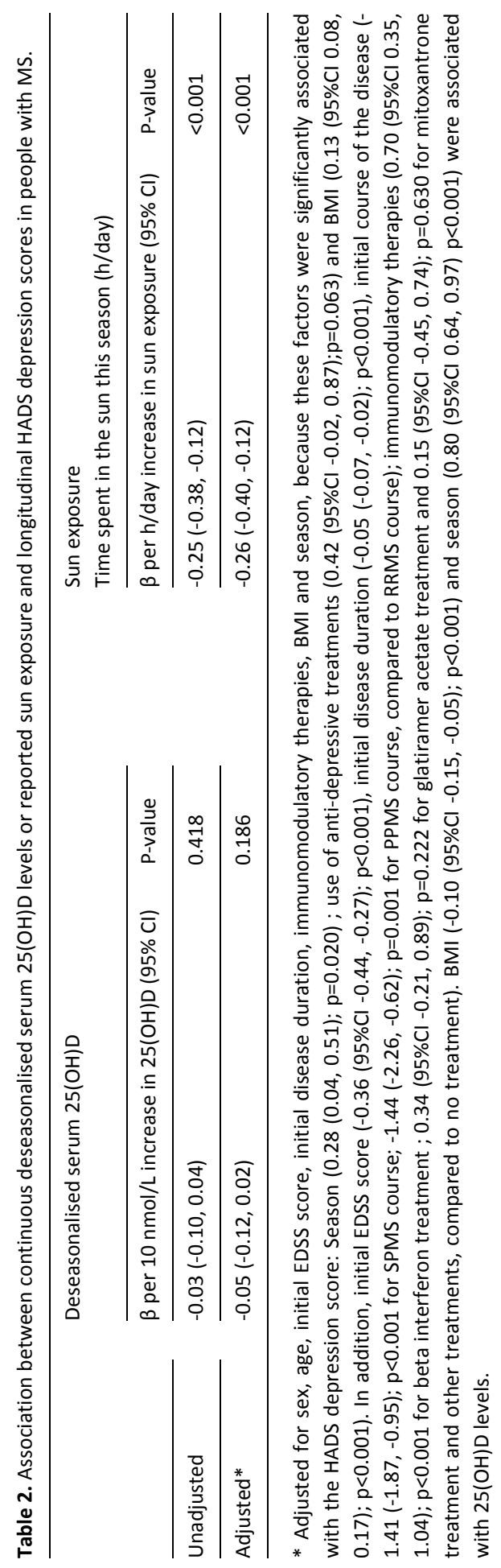




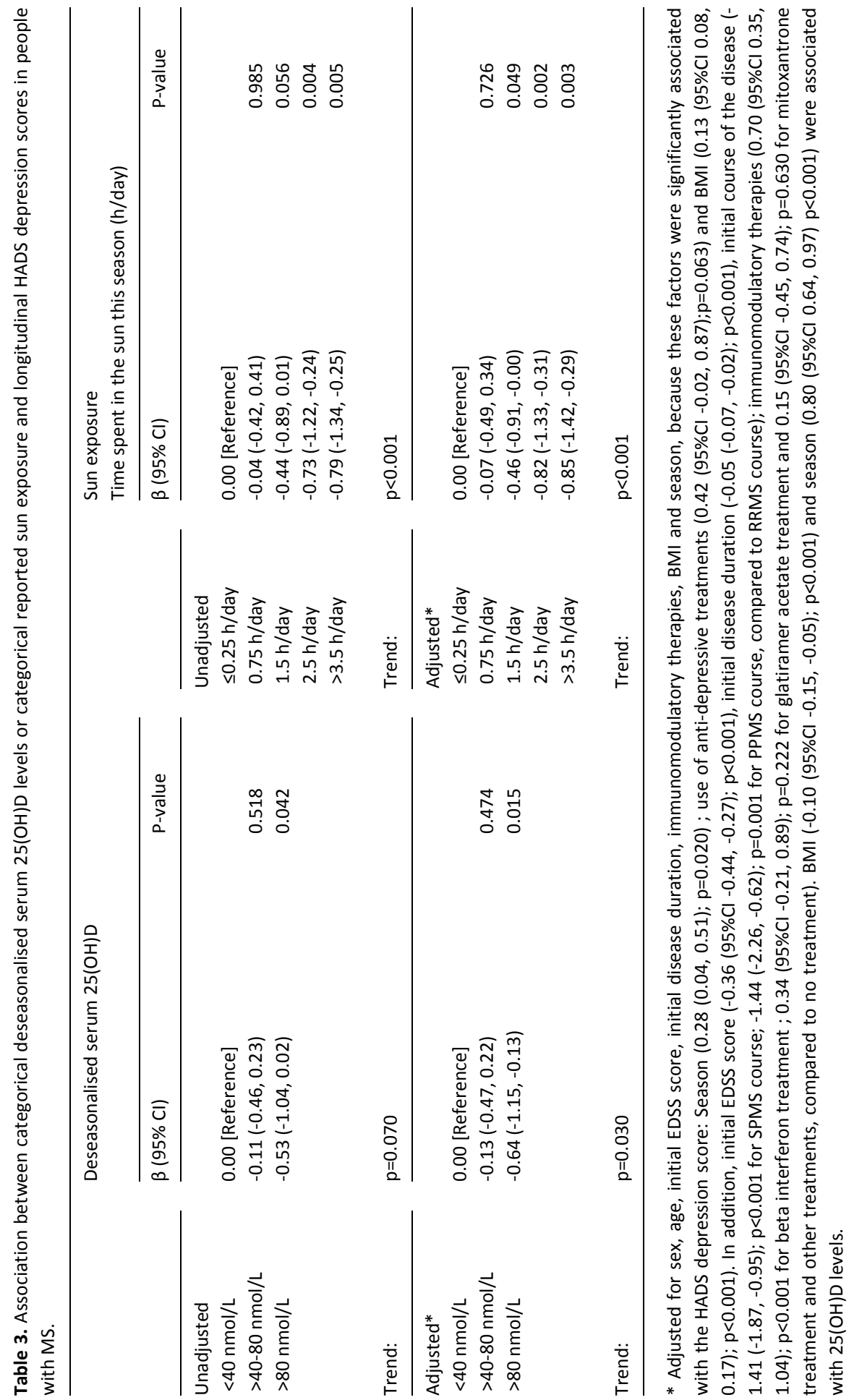




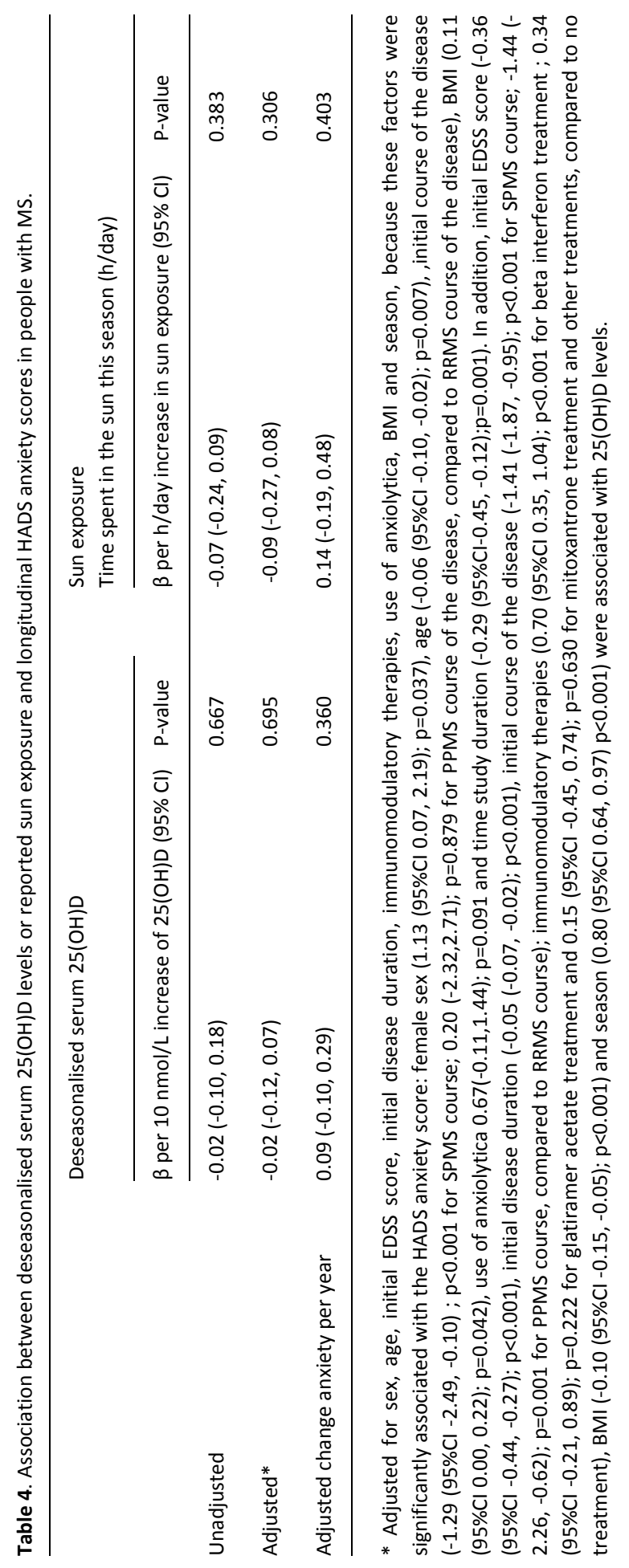




\section{CHAPTER 8}

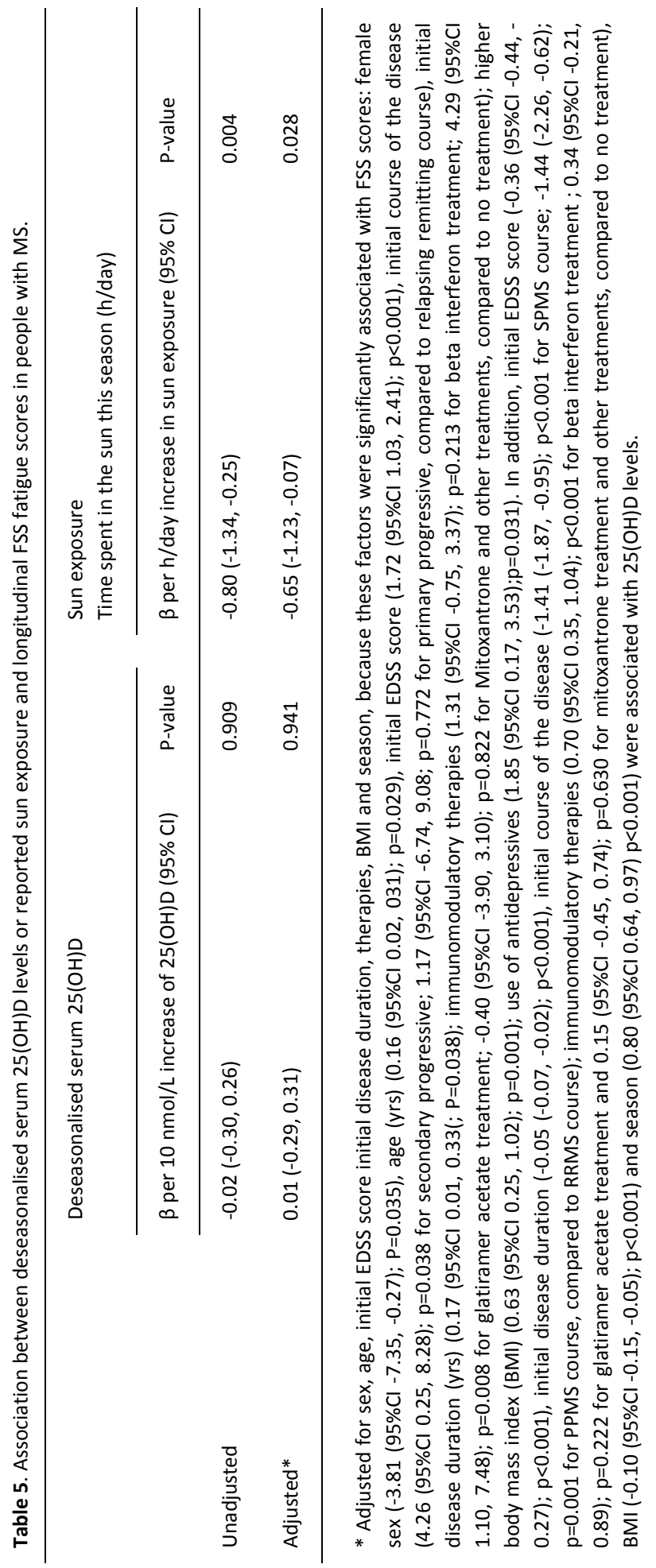


SUN EXPOSURE, VITAMIN D AND DEPRESSION IN MULTIPLE SCLEROSIS

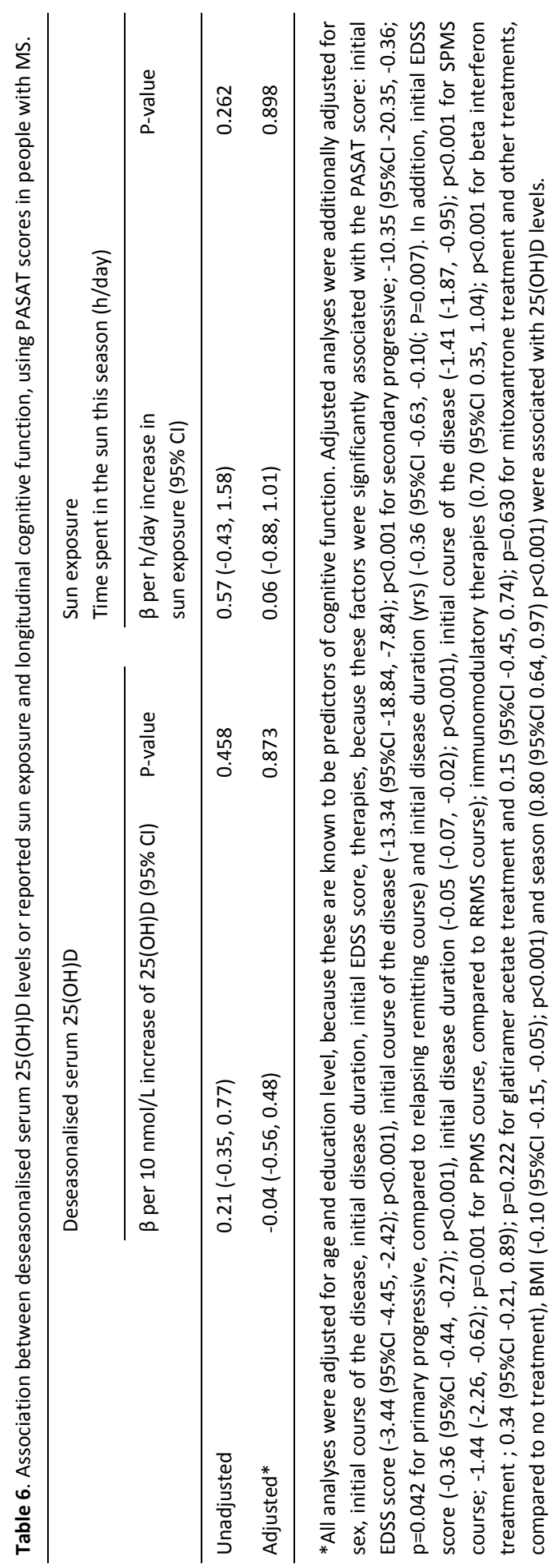




\section{CHAPTER 8}

\section{References}

1. Compston, A. and A. Coles, Multiple sclerosis. Lancet, 2008. 372(9648): p. 1502-17.

2. Simpson, S., Jr., et al., Latitude is significantly associated with the prevalence of multiple sclerosis: a meta-analysis. J Neurol Neurosurg Psychiatry, 2011. 82(10): p. 1132-41.

3. Hart, P.H., S. Gorman, and J.J. Finlay-Jones, Modulation of the immune system by UV radiation: more than just the effects of vitamin D? Nat Rev Immunol, 2011. 11(9): p. 584-96.

4. Ascherio, A., K.L. Munger, and K.C. Simon, Vitamin D and multiple sclerosis. Lancet Neurol, 2010. 9(6): p. 599-612.

5. Eyles, D.W., et al., Distribution of the vitamin D receptor and 1 alpha-hydroxylase in human brain. J Chem Neuroanat, 2005. 29(1): p. 21-30.

6. Peelen, E., et al., Effects of vitamin D on the peripheral adaptive immune system: a review. Autoimmun Rev, 2011. 10(12): p. 733-43.

7. Zerwekh, J.E., Blood biomarkers of vitamin D status. Am J Clin Nutr, 2008. 87(4): p. 1087S-91S.

8. Baarnhielm, M., et al., Sunlight is associated with decreased multiple sclerosis risk: no interaction with human leukocyte antigen-DRB1*15. European journal of neurology : the official journal of the European Federation of Neurological Societies, 2012. 19(7): p. 955-62.

9. Munger, K.L., et al., Vitamin D intake and incidence of multiple sclerosis. Neurology, 2004. 62(1): p. 605 .

10. Munger, K.L., et al., Serum 25-hydroxyvitamin D levels and risk of multiple sclerosis. Jama, 2006. 296(23): p. 2832-8.

11. Smolders, J., et al., Association of vitamin D metabolite levels with relapse rate and disability in multiple sclerosis. Mult Scler, 2008. 14(9): p. 1220-4.

12. Branas, P., et al., Treatments for fatigue in multiple sclerosis: a rapid and systematic review. Health Technol Assess, 2000. 4(27): p. 1-61.

13. Beiske, A.G., et al., Depression and anxiety amongst multiple sclerosis patients. Eur J Neurol, 2008. 15(3): p. 239-45.

14. Chiaravalloti, N.D. and J. DeLuca, Cognitive impairment in multiple sclerosis. Lancet Neurol, 2008. 7(12): p. 1139-51.

15. Annweiler, C., et al., Cognitive effects of vitamin D supplementation in older outpatients visiting a memory clinic: a pre-post study. J Am Geriatr Soc, 2012. 60(4): p. 793-5.

16. Askmark, H., et al., Vitamin D deficiency in patients with myasthenia gravis and improvement of fatigue after supplementation of vitamin D3: a pilot study. Eur J Neurol, 2012.

17. Ganji, V., et al., Serum vitamin D concentrations are related to depression in young adult US population: the Third National Health and Nutrition Examination Survey. Int Arch Med, 2010. 3: p. 29.

18. Knippenberg, S., et al., Vitamin D status in patients with MS is negatively correlated with depression, but not with fatigue. Acta Neurol Scand, 2011. 124(3): p. 171-5.

19. Dean, A.J., et al., Effects of vitamin D supplementation on cognitive and emotional functioning in young adults--a randomised controlled trial. PLoS One, 2011. 6(11): p. e25966.

20. Kampman, M.T., et al., Effect of vitamin D3 supplementation on relapses, disease progression, and measures of function in persons with multiple sclerosis: exploratory outcomes from a double-blind randomised controlled trial. Mult Scler, 2012. 18(8): p. 1144-51.

21. Kjaergaard, M., et al., Effect of vitamin D supplement on depression scores in people with low levels of serum 25-hydroxyvitamin D: nested case-control study and randomised clinical trial. Br J Psychiatry, 2012.

22. Pittas, F., et al., Smoking is associated with progressive disease course and increased progression in clinical disability in a prospective cohort of people with multiple sclerosis. Journal of neurology, 2009. 256(4): p. 577-85. 
23. McDonald, W.I., et al., Recommended diagnostic criteria for multiple sclerosis: guidelines from the International Panel on the diagnosis of multiple sclerosis. Ann Neurol, 2001. 50(1): p. 121-7.

24. Simpson, S., Jr., et al., Higher 25-hydroxyvitamin D is associated with lower relapse risk in multiple sclerosis. Ann Neurol, 2010. 68(2): p. 193-203.

25. Zigmond, A.S. and R.P. Snaith, The hospital anxiety and depression scale. Acta Psychiatr Scand, 1983. 67(6): p. 361-70.

26. Honarmand, K. and A. Feinstein, Validation of the Hospital Anxiety and Depression Scale for use with multiple sclerosis patients. Mult Scler, 2009. 15(12): p. 1518-24.

27. Krupp, L.B., et al., The fatigue severity scale. Application to patients with multiple sclerosis and systemic lupus erythematosus. Arch Neurol, 1989. 46(10): p. 1121-3.

28. Tellez, N., et al., Fatigue in multiple sclerosis persists over time: a longitudinal study. J Neurol, 2006. 253(11): p. 1466-70.

29. Tombaugh, T.N., A comprehensive review of the Paced Auditory Serial Addition Test (PASAT). Arch Clin Neuropsychol, 2006. 21(1): p. 53-76.

30. van der Mei, I.A., et al., Validity and reliability of adult recall of past sun exposure in a case-contro study of multiple sclerosis. Cancer Epidemiol Biomarkers Prev, 2006. 15(8): p. 1538-44.

31. van der Mei, I.A., et al., Past exposure to sun, skin phenotype, and risk of multiple sclerosis: casecontrol study. BMJ, 2003. 327(7410): p. 316.

32. Shreedhar, V., et al., A cytokine cascade including prostaglandin E2, IL-4, and IL-10 is responsible for UV-induced systemic immune suppression. J Immunol, 1998. 160(8): p. 3783-9.

33. Dowlati, Y., et al., A meta-analysis of cytokines in major depression. Biol Psychiatry, 2010. 67(5): p. 44657.

34. Kubera, M., et al., Anti-Inflammatory effects of antidepressants through suppression of the interferongamma/interleukin-10 production ratio. J Clin Psychopharmacol, 2001. 21(2): p. 199-206.

35. Haase, C.G., M. Tinnefeld, and P.M. Faustmann, The influence of immunomodulation on psychoneuroimmunological functions in benign multiple sclerosis. Neuroimmunomodulation, 2004. 11(6): p. 365-72.

36. Mehta, B.K., New hypotheses on sunlight and the geographic variability of multiple sclerosis prevalence. J Neurol Sci, 2010. 292(1-2): p. 5-10.

37. Heesen, C., et al., Fatigue in multiple sclerosis: an example of cytokine mediated sickness behaviour? J Neurol Neurosurg Psychiatry, 2006. 77(1): p. 34-9.

38. Melamud, L., et al., Melatonin dysregulation, sleep disturbances and fatigue in multiple sclerosis. $J$ Neurol Sci, 2011. 314(1-2): p. 37-40.

39. Pan, A., et al., Association between depressive symptoms and 25-hydroxyvitamin D in middle-aged and elderly Chinese. J Affect Disord, 2009. 118(1-3): p. 240-3.

40. Jorde, R., et al., Effects of vitamin D supplementation on symptoms of depression in overweight and obese subjects: randomized double blind trial. J Intern Med, 2008. 264(6): p. 599-609.

41. Handel, A.E. and S.V. Ramagopalan, Vitamin D and multiple sclerosis: an interaction between genes and environment. Mult Scler, 2012. 18(1): p. 2-4. 

Chapter 9

General discussion 


\section{CHAPTER 9}

\section{Introduction}

There is increasing evidence of a beneficial role for vitamin $D$ in the pathology of multiple sclerosis (MS). Epidemiological research shows that a low vitamin $D$ status is associated with a higher risk of developing MS (1) and RRMS patients with a low vitamin D status have higher odds on a relapse (2). The underlying mechanism of vitamin $D$ in these associations has not been unravelled, but a role on immune regulation has been proposed (3). In particular antigen presenting cells (APC) and T cells were shown to be affected by vitamin $D$. Recently, more attention has been drawn to $B$ cells in the pathogenesis of MS, however, this has not yet resulted in many studies exploring the relationship between vitamin $D$ and $B$ cell subsets and/or functions.

In this thesis we explored the role of vitamin D, as measured with 25(OH)D levels, in MS patients on both immunological and clinical outcomes to assess its role as a disease modulator. We hypothesized that next to APC and T cells, vitamin D also modulates B cells. In addition, we hypothesized that vitamin D modulates specific clinical symptoms, in particular vision, fatigue and neuropsychiatric symptoms. For this reason, we explored $B$ cells subsets in MS patients during remission and during active disease and subsequently the association between $B$ cell subsets and vitamin $D$ status. We also explored whether $B$ cell subsets are affected by vitamin $D$ supplementation. In the second part of the thesis, we investigated the relationship between clinical outcomes, such as visual outcomes, fatigue, depression, anxiety, and cognition and vita$\min \mathrm{D}$ status in MS patients.

\section{The main findings of this thesis are:}

- In MS patients, a decrease in the percentage of circulating memory B cells can be seen compared to healthy controls (chapter 4).

- In vitro, vitamin D affects B cell subsets (reviewed in chapter 2).

- Ex vivo, we observed no hints that vitamin $D$ acts on naive and memory $B$ cell subsets in MS patients (chapter 3 and 4).

- There is currently insufficient randomized controlled trial (RCT) evidence to recommend vitamin D supplementation outside trials to improve clinical symptoms as relapse rate and disability progression (chapter 5 ).

- There is sufficient evidence to justify assessing and correcting vitamin $D$ and calcium levels to optimize bone health in people with MS at high absolute risk of fracture (chapter 5).

- High 25(OH)D levels correlate with decreased retinal nerve fibre layer thickness in MS patients, in particular in MS patients without prior history of optic neuritis (ON) (chapter 6). 
- Although retrospectively we found a negative association between 25(OH)D levels and depressive symptoms (chapter 7), we could not confirm this association in a large prospective study (chapter 8).

- Higher levels of sun exposure, instead of higher 25(OH)D levels, are associated with lower levels of fatigue and depression (chapter 8).

- No association is observed between 25(OH)D levels or sun exposure and levels of anxiety and cognitive performance (chapter 8 ).

In the next paragraphs we will shortly discuss our main findings in the context of previous research. Firstly, we will focus on the immunological outcomes and vitamin D status in MS. For this purpose, we will first review the role of B cell subsets in MS. Hereafter, we will discuss the potential roles of vitamin $D$ on these different $B$ cell subsets/functions. Secondly, we will discuss the relationship between vitamin $D$ and common clinical symptoms in MS. The focus of our discussion will be on depression.

This integration of data will be followed by implications and ideas for future research to further explore the role of vitamin $D$ as a disease modulator in MS.

\section{Immunological outcomes and vitamin D status in MS}

$B$ cells are increasingly recognized in the pathogenesis of MS. The strongest evidence for a role of B cells in MS was the demonstration that peripheral B cell depletion by Rituximab leads to a reduction in disease activity in MS (4). Also plasma exchange was shown to be an effective therapy in steroid-unresponsive exacerbations in MS, which has been attributed to the removal of circulating antibodies (5). Intrathecal IgG synthesis has long been considered an important supportive criterion for the diagnosis MS (6). Besides intrathecal IgG synthesis, B cell follicle-like structures are found in the meninges of MS patients (7). Whether the critical role of B cells in the pathogenesis of MS occurs in the secondary lymphoid tissues, in the CNS, or in both compartments, has not yet been determined. We hypothesize that both compartments play an important role for B cells in MS. It should be kept in mind that B cells in peripheral blood are often measured as representative for $B$ cells in the secondary lymphoid tissues. In addition, B cells in CSF are used as representative for B cells in the CNS. We will further elaborate on the role of $B$ cells in the different compartments in the next paragraphs.

\section{$B$ cells in MS}

Within the lymphoid tissues, naive $B$ cell activation is triggered by antigen recognition by their $B$ cell receptor (BCR). For a long lasting response after this $B C R$ triggering, $T$ cell help is required. The naïve activated $B$ cells internalize and process their BCR with the antigen and then display peptides of it in their major histocompatibility complex (MHC) class II. The MHC complex can be recognized by a T cell receptor (TCR). This 


\section{CHAPTER 9}

interaction between $B$ cells and $T$ cells results in activation of B cells that subsequently enter into the germinal centre. The germinal centre is important in the generation of plasma cells and class switched memory cells, the traditional effector B cells (Figure 1). The interaction between $B$ cells and $T$ cells also leads to the activation of $T$ cells resulting in an up-regulation of CD40 Ligand (CD40L). This up-regulation is necessary for reciprocal $B$ cell stimulation through its ligand CD40 (8). B cell activation on the other hand, is accompanied by an up-regulation of CD80 and CD86 surface expression (9, 10), enabling $B$ cells to activate memory $T$ cells by binding $C D 28$ (11). It is thought that by up-regulation of the co-stimulatory molecules, activated B cells are able to act as efficient APC for T cells, and thereby to maintain T cell polarity. Dysfunction of this role, however, could re-direct T cell polarity and thereby contribute to disease manifestation in MS. Figure 2 shows potential mechanisms of the APC function of B cells in MS.

In particular memory B cells were shown to act as efficient APC to activate T cells. In healthy donors, a subset of resting memory $\mathrm{CD}^{\circ} 0^{+} \mathrm{B}$ cells was very efficient in inducing $\mathrm{CD}^{+} \mathrm{T}$ cell proliferation (10). Interestingly, in RRMS patients circulating $\mathrm{CD}^{\circ} 0^{+} \mathrm{B}$ cells were found to be increased during active disease, compared to RRMS patients in remission and healthy controls (12). B cell depletion in MS patients resulted in a decreased T cell proliferation in peripheral blood mononuclear cells (PBMC) cultures (13). Besides their role as APC, B cells can produce cytokines. Memory B cells were shown to produce more pro-inflammatory cytokines compared to naïve $B$ cells (14). This may enable memory B cells to skew T cells towards Th1 or Th17 cell differentiation. Indeed, B cell depletion in MS patients by Rituximab resulted in a decreased IFN- $\gamma$ and IL-17 production by $\mathrm{CD}^{+} \mathrm{T}$ cells. Therefore, the reduced $\mathrm{T}$ cell proliferation after $\mathrm{B}$ cell depletion may also be the result of a lack of $B$ cells secreting the pro-inflammatory cytokines (13). 


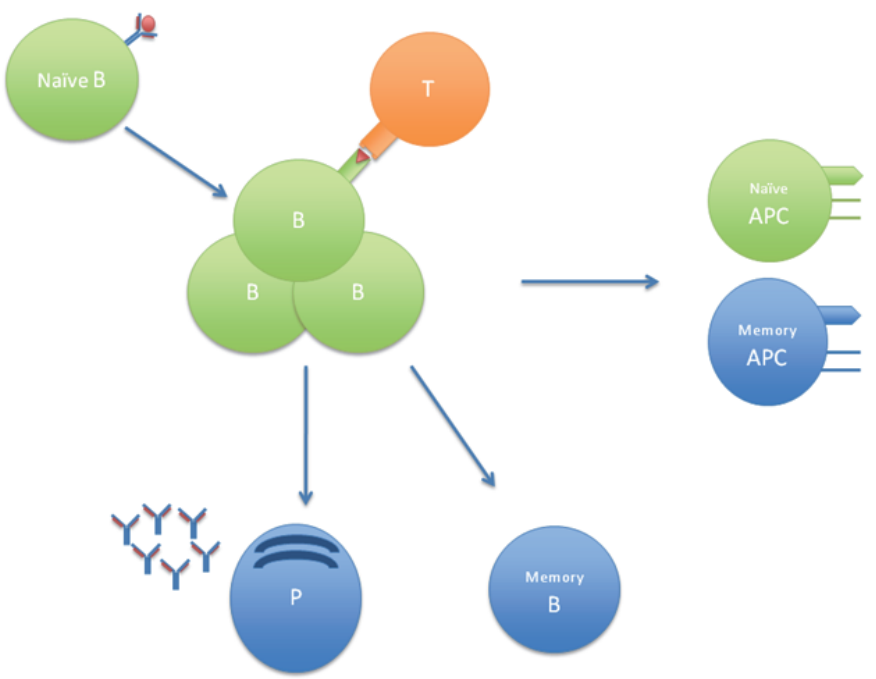

Figure 1. Naïve $B$ cells recognize an antigen by their B cell receptor (BCR). Naive $B$ cells present this antigen which is recognized by the $T$ cell. This results in $B$ cell differentiation into plasma cells $(P)$, memory $B$ cells, or in antigen presenting $B$ cells (APC).

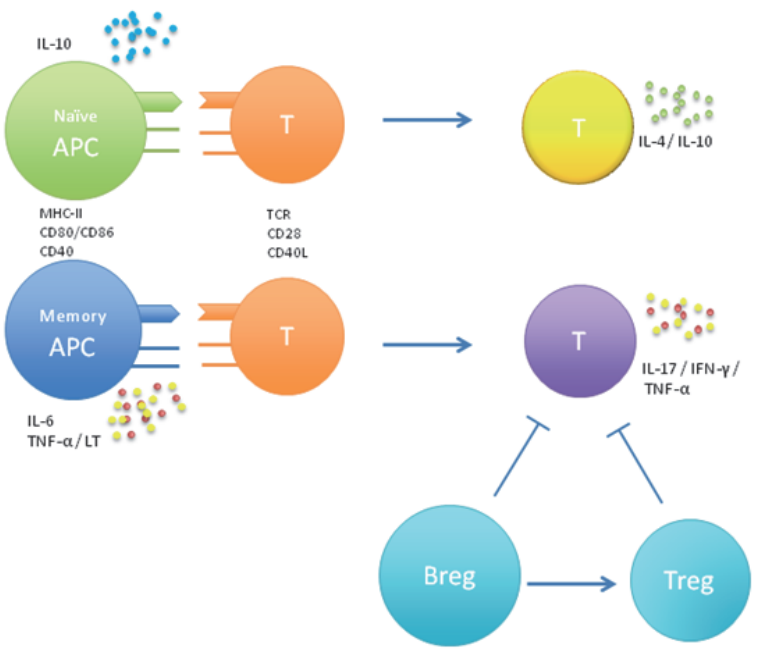

Figure 2. Antigen presenting function of B cells. B cells can act as efficient antigen presenting cells (APC). Memory B cells produce pro-inflammatory cytokines and are able to activate T cells which will differentiate into Th1 or Th17 cells. Naïve B cells on the other hand, are able to produce anti-inflammatory cytokines, and will preferentially stimulate $T$ cells to differentiate into Th2 cells. Regulatory B cells can inhibit Th17 and Th1 cells, however, they are also able to stimulate regulatory $\mathrm{T}$ cells, enhancing the inhibitory function. 


\section{CHAPTER 9}

Naïve B cells are less capable of presenting antigens to T cells $(15,16)$. Resting naïve $B$ cells were unable to stimulate $T$ cell proliferation (9). After activation, naïve $B$ cells do express co-stimulatory molecules CD80 and CD40 resulting in T cell proliferation (17). However, naïve B cells did not induce significant IFN- $\gamma$ secretion by $T$ cells as compared to memory $B$ cells (18). Moreover, in a mouse model naïve B cells were shown to induce $T$ cell proliferation and differentiation into regulatory T cells (Treg) (19). This might be explained by the fact that naïve $B$ cells were shown to produce antiinflammatory cytokines (14), preferentially skewing the T cell response towards Th2 or Treg. It could be speculated that naïve B cells are important drivers of a tolerant environment. This is supported by the finding that naïve B cells, unlike memory B cells, restored more quickly after Rituximab treatment in systemic lupus erythemathosus (SLE) patients without recurrence of disease activity. It is also thought that naïve B cells are a source of IL-10 producing regulatory B cells (Breg) (20). Breg were shown to modulate $\mathrm{T}$ cell responses towards anti-inflammatory responses, and in particular towards Tregs (21). In SLE patients depletion of a naïve B cell subset able to produce IL-10, resulted in a higher proportion of T cells producing TNF- $\alpha$ and IFN- $\gamma$ (22). Stimulations used to induce IL-10 secretion by $B$ cells are for example toll like receptor (TLR)agonists. In chapter 4 we used CpG, a TLR-9 agonist, to induce IL-10 secretion in B cells. Normally, TLR-agonists activate dendritic cells (DC) within minutes, while TLR activated B cells start secreting IL-10 after 24-48 hours (23). This suggest that during a microbial infection DCs can act within minutes to properly activate the immune system, while the IL-10 secretion by B cells may serve as a feedback loop to acquiesce an overshooting immune response after several days. Interestingly, both the proportion of Breg as well as the IL-10 secretion in supernatant was reduced after TLR stimulation of B cells from MS patients ((24) and chapter 4). Not only naïve, also memory B cells have the capacity to produce IL-10 (25). It is suggested that naïve and memory Bregs have distinct roles in autoimmune diseases. The naïve Breg is thought to be important in preventing inflammatory responses in autoimmune diseases, whereas memory Breg may function primarily in resolving active disease exacerbations (26). Interestingly, we found a shift in naïve / memory ratio within Breg in favour of memory Breg in MS patients during active disease (chapter 4).

Another important difference between naive and memory $B$ cells includes their ability to travel towards the CNS. Memory B cells express high levels of the surface molecule very late antigen-4 (VLA-4), even higher as compared to T cells (27). This enables memory $B$ cells to adhere to and migrate efficiently through the endothelial cells of the blood brain barrier (BBB). In particular switched memory $B$ cells express high levels of VLA-4 compared to naïve B cells (28). The switched memory B cell is also the subset mostly seen in CSF samples from RRMS patients with active disease $(29,30)$. Recently, it was demonstrated that chemokine C-X-C-motif ligand 13 (CXCL13) levels in CSF are higher in MS compared to other inflammatory and non-inflammatory neurological diseases (31). CXCL13 is a chemokine that guides B cells to follicles in secondary 
lymphoid organs (32). Another molecular signal that allows $B$ cells to enter, mature and persist within the CNS may be B cell activating factor (BAFF). BAFF is a member of the tumor necrosis factor (TNF) superfamily (33). BAFF is constitutively expressed in the normal human brain and BAFF expression is up-regulated in MS plaques (34). The combination of CXCL13 and BAFF was shown to increase chemotaxis of memory B cells more strongly than that of naive B cells in vitro (35). CXCL13 and BAFF are probably also important in the establishment of the follicle like structures in the meninges of MS patients. These follicles contain proliferating B cells, T cells and dendritic cells and are most likely important places for further in situ activation of the inflammatory cells (7). Indeed, the presence of these follicles is associated with more severe pathology (36). The follicles might facilitate $B$ cells to undergo rapid and extensive $T$ cell mediated antigen driven clonal expansion (37). Memory B cells can become activated again and enter the parenchyma and together with activated T cells, macrophages and microglial cells, secrete pro-inflammatory cytokines and soluble mediators that trigger demyelination. In addition, memory B cells can become rapidly activated in the follicles to differentiate into antibody secreting plasma cells. The local antibody production is responsible for the oligoclonal bands, which can be found in CSF in $90 \%$ of MS patients (38). The exact role of the antibodies in CSF is not clear, since the antigen specificity of these antibodies is ill defined. Recently, in a subgroup of MS patients antibodies to KIR4.1 were demonstrated. KIR4.1 is a potassium channel, and the antibodies to it have been suggested to interfere with the function of KIR4.1, resulting in a disturbance of neurotransmitter homeostasis (39). Further, it is suggested that demyelination can be mediated by poorly defined antibodies and complement through opsonisation and subsequent phagocytosis by macrophages (40). There may also be a role for the Breg within the CNS. In EAE, B cells have been reported to facilitate the recruitment of Treg to the CNS (41). Therefore, in MS, the role of the naive Breg within the CNS could be recruitment of Treg, trying to prevent the inflammatory response by $T$ cells. The role of the memory Breg could be suppression of plasma cells in MS plaques and CSF, and suppression of $B$ and $T$ cells secreting pro-inflammatory cytokines in more active disease (Figure 3 summarizes the role of $B$ cells within the CNS.) 


\section{CHAPTER 9}

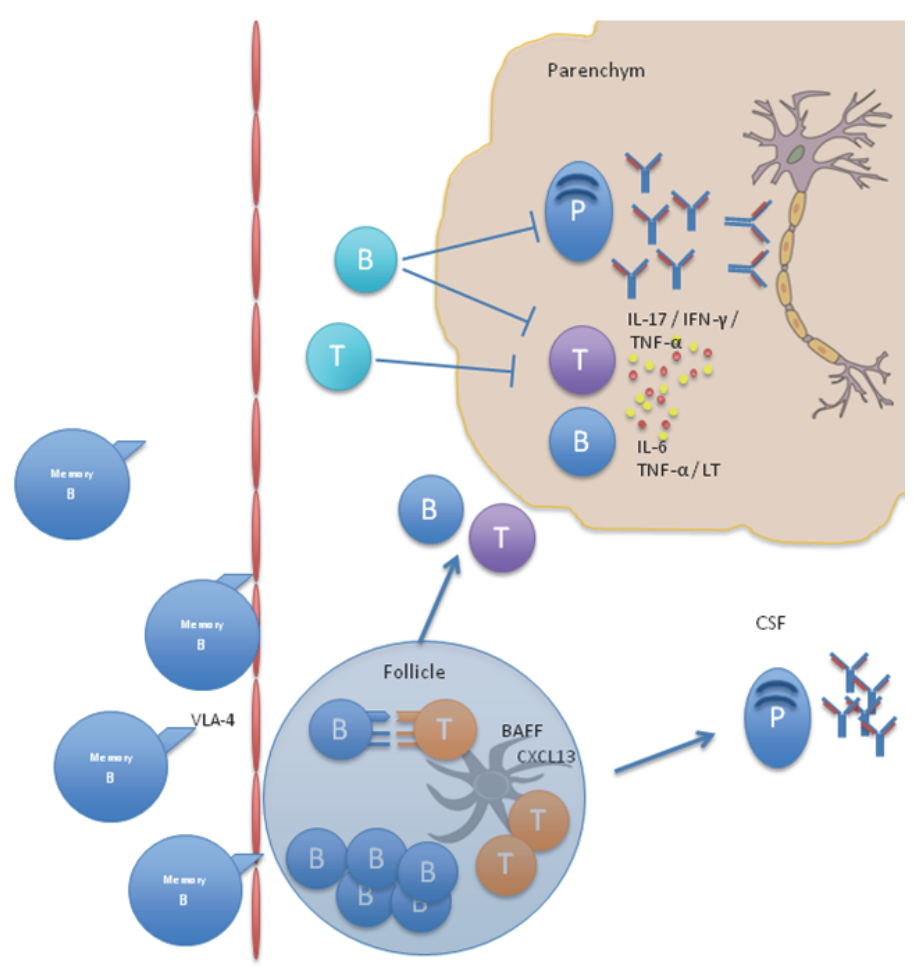

Figure 3. $B$ cells in the central nervous system. Within the CNS of MS patients CXCL13 and BAFF are highly expressed, attracting in particular memory B cells. Memory $B$ cells in the periphery express VLA-4, enabling them to adhere to and cross the blood brain barrier (BBB). After crossing the BBB, B cells can become reactivated in the follicles. Activated memory $B$ cells can enter the parenchyma and cause damage by releasing pro-inflammatory cytokines. In addition, memory B cells can become activated to form plasma cells and produce antibodies, facilitating damage to the myelin sheath and neurons. The IL-10 producing B cells in turn, are able to dampen the pro-inflammatory cytokine secretion and antibody secretion.

Another interesting B cell subset to explore in MS is the B1 cell. B1 cells produce natural IgM antibodies, which are important for the early response to bacterial and viral infections. B1 cells have constitutively up-regulated expression of plasma cell specific genes, which may explain their spontaneous and continuous secretion of IgM. After innate immune signals, such as TLR agonists, a relative enhanced response is seen, while B1 cells have a selective unresponsiveness to BCR induced clonal expansion (42). The natural antibodies produced by B1 cells play an important role in the clearance of apoptotic cells and released autoantigens (43). In SLE for example, it is accepted that IgG antibodies, but not IgM antibodies, are pathogenic (44). Moreover, IgM deficiency appeared to accelerate autoimmunity in a mouse model by increased levels of IgG (43). In addition, IgM antibodies are also thought to have a protective role in athero- 
sclerosis (reviewed in (45)). In contradiction, elevated numbers of B1 cells have also been associated with autoimmunity as being pathogenic both in human and mouse models (reviewed in (46)). Several mechanisms have been suggested to explain the possible role of B1 cells in autoimmune pathogenesis: production of pathogenic autoantibody, presentation of self-antigen to autoreactive $T$ cells and their ability to secrete cytokines, such as IL-10. In MS the latter two functions could be of particular importance. The phenotypic markers for human $\mathrm{B} 1$ cells have been described in peripheral B cells as $\mathrm{CD} 20^{+} \mathrm{CD} 27^{+} \mathrm{CD} 3^{+} \mathrm{CD}^{-} 0^{-}$(47). Recently, a subdivision in these $\mathrm{B} 1$ cells was made according to expression of $\mathrm{CD} 11 \mathrm{~b} . \mathrm{CD} 20^{+} \mathrm{CD} 27^{+} \mathrm{CD} 43^{+} \mathrm{CD} 70^{-} \mathrm{B} 1$ cells expressing $\mathrm{CD} 11 \mathrm{~b}$ strongly stimulate $\mathrm{T}$ cells through $\mathrm{CD} 86$ expression but produce modest levels of IgM. CD $20^{+} \mathrm{CD} 27^{+} \mathrm{CD}_{4} 3^{+} \mathrm{CD} 70^{-} \mathrm{B} 1$ cells negative for $\mathrm{CD} 11 \mathrm{~b}$ secreted abundant amounts of IgM, but were less effective in $\mathrm{T}$ cell stimulation. Interestingly, B1 cells expressing CD11b, and thus efficient $T$ cells stimulators, were found to be increased in SLE patients (48). In addition, MS patients that were responsive to nataluzimab treatment and remained free of new disease activity experienced all a decrease in IgM index, as determined by CSF/serum IgM : CSF/serum albumin (49). Considering these findings, exploring both subsets of $B 1$ cells is of interest in MS. The CD11b ${ }^{+} B 1$ cell is of particular interest in the periphery were it could serve as a potent $T$ cell stimulator. The CD11b ${ }^{-}$B1 cell on the other hand, might be more important in the CNS, the place where natural antibodies could be harmful.

\section{$B$ cells and vitamin D status in MS}

The effect of vitamin D on B cells is relatively unexplored (Chapter 2 (50)). Upon activation, B cells express cyp24B1, enabling the metabolism of 25(OH)D into the active metabolite $1,25(\mathrm{OH})_{2} \mathrm{D}$, as well as the vitamin $\mathrm{D}$ receptor (VDR). In vitro several effects of vitamin $D$ on $B$ cells have been described, including the inhibition of B cell proliferation, inhibition of differentiation into plasma cells or into switched memory B cells, decreased IgE secretion, and an increased IL-10 secretion by B cells (51-54). In vivo data, however, are scarce $(1,3)$.

Regarding the growing importance of both vitamin D and B cells in MS, we explored the effect of high dose vitamin D supplementation on B cell differentiation in MS (chapter 3 (55)). We could not establish an effect of vitamin D supplementation in RRMS patients. Next, we explored the B cell differentiation profile in RRMS patients as compared to matched healthy controls (chapter 4 (56)). Interestingly, we saw a relative decrease in circulating memory $B$ cells in RRMS patients. Although we could not demonstrate a significant difference in circulating B cell subsets between stable disease and active disease, Haas et al. did show a significant decrease in switched memory B cells in RRMS patients with active disease compared to stable disease (57). Moreover, since parallel CSF samples were available from these patients, Haas et al. observed a concomitant increase of memory B cells in CSF during active disease. This supports our hypothesis that memory B cells play an important role in the CNS during 


\section{CHAPTER 9}

active disease. Finally, we explored the correlation between the proportion of IL-10 producing $B$ cells and vitamin D status in healthy controls and RRMS patients during resting and active disease. However, we could not demonstrate a correlation between IL-10 producing B cells and vitamin D status.

Although it remains a possibility that vitamin D does not affect B cells, there could be several other explanations for the lack of findings between vitamin $D$ status and $B$ cell subsets in our data. First, our studies could lack sufficient power. In chapter 3 we measured B cell subsets in 15 MS patients before and after vitamin D supplementation. Despite the fact that these 15 patients were sufficient to measure a difference in T cell cytokine secretion before and after vitamin D supplementation (58), we could not demonstrate an effect on B cell differentiation. Regrettably, we were unable to measure IL-10 producing B cells in the supplementation study; an effect of vitamin D supplementation on this B cell subset cannot be excluded. In addition, in contrast to the study of Haas et al. where more patients were included, we could not demonstrate a difference in B cell subsets between patients with active and resting disease. Similarly, the lack of a correlation between B cells and vitamin D status could be the result of a power problem. For future research therefore, it is preferable to include a higher number of patients. Based on the findings in chapter 4, 189 patients would have to be included per arm, to demonstrate a significant difference between naïve B cell subsets in MS patients with active and resting disease.

Second, the phenotypic markers we used could be less sensitive to measure a derangement caused by vitamin D in B cell subsets. However in patients with SLE and in primary Sjögren syndrome, a derangement of the circulating B cell subsets, as examined in our studies, has been reported $(59,60)$. Other phenotypic markers might be of interest to explore, for example the $\mathrm{CD} 20^{+} \mathrm{CD} 27^{+} \mathrm{CD} 43^{+} \mathrm{CD} 70^{-} \mathrm{CD} 11 \mathrm{~b}^{+}$or $\mathrm{CD} 11 \mathrm{~b}^{-} \mathrm{B} 1$ cells. Considering the immune modulating function of vitamin $D$, we hypothesize that a lower vitamin D status is associated with a higher percentage of CD11 ${ }^{+}$B1 cells in MS, since this subset was shown to be an effective APC for T cells (48). Regarding the potential functions of B cells in MS (Figure 1), exploring the effect of vitamin D on the APC capacity would be of interest. Likewise, one of the beneficial effects of vitamin D includes the down regulation of co-stimulatory molecules on dendritic cells (DC) reducing their APC function (discussed in chapter 2). In addition, exploring an effect on cytokine secretion would be of interest. It should be kept in mind that we only measured IL-10 production in B cells, whereas other cytokines produced by $B$ cells, for example IL-6, IL-12 and TNF- $\alpha$, might be interesting as well. We hypothesize that a higher vitamin D status decreases pro-inflammatory cytokine secretion by B cells, which is important in mediating the $T$ cell response towards an anti-inflammatory response. Although we could not demonstrate a correlation between the proportion of IL-10 producing B cells after TLR-9 activation and vitamin D status, this does not exclude an effect of vitamin D on IL-10 producing B cells. Other stimulation protocols might be more sensitive to measure a correlation between IL-10 producing B cells and vitamin D 
status. Indeed, B cells activated by TLR agonists in vitro did not up-regulate VDR, unlike $B$ cells activated by BCR cross linking, anti-CD40 and IL-4 (54). In addition, it is possible that the proportion of IL-10 producing $B$ cells remains stable after activation, but IL-10 secretion, as measured in supernatant, might increase.

Finally, exploring the effect of vitamin $D$ at the site of inflammation, that is the CNS, might be more relevant. Here $B$ cells might be activated and thus might have upregulated VDR, increasing the probability of a relationship with vitamin $D(61)$. In addition, exploring the correlations with molecules facilitating B cells to enter the CNS and form follicles might be interesting. In peripheral blood we saw a trend towards a decrease in BAFF levels in peripheral blood after vitamin D supplementation in MS (chapter 3). Since BAFF was shown to be up-regulated in CNS in MS, exploring the correlation between vitamin $D$ and BAFF within the CNS might be more relevant.

In sum, although vitamin $D$ has been shown to be a potent immune modulator on T cells and DCs, as discussed in chapter $\mathbf{2}$, we could not demonstrate correlations between circulating B cell subsets and vitamin D status ex vivo in chapter $\mathbf{3}$ and $\mathbf{4}$. However, it is now possible to study additional $B$ cell subsets of interest, such as regulatory $B$ cells and B1 cells, since their specific markers are now better described. Therefore, the newly and better described $B$ cell subsets provide future directions to further explore an effect of vitamin D within the growing field of B cell biology in MS.

\section{Clinical symptoms and vitamin D status in MS}

Previous research shows that vitamin D has an important role as an immune modulator. Consequently, this may influence clinical symptoms and disease course in MS. Although loss of motor function and subsequent loss of mobility are well recognized clinical symptoms, visual impairment, fatigue and neuropsychiatric symptoms are frequent and important predictors of quality of life of MS patients. Because disability, as measured by the expanded disability status scale (EDSS) score, has been associated with vitamin $\mathrm{D}$ status in previous research, we explored whether visual impairment, fatigue and neuropsychiatric symptoms, such as depression, anxiety and cognitive impairment, are associated with low vitamin D status in MS patients (Chapters 6-8). In the following paragraphs, we will discuss our main findings.

\section{Visual impairment and vitamin D in MS}

In chapter 6 we explored whether vitamin D status is associated with visual impairment in MS patients. Recently, low vitamin D status has been associated with the prevalence of age-related macular degeneration (AMD) (62). In AMD, the leading cause of irreversible loss of vision in developed countries (63), inflammation is thought to be involved in the pathogenesis (64). Therefore, the underlying mechanism in this association may be the effect of vitamin D on inflammation. However, in our study we 


\section{CHAPTER 9}

found no correlation between vitamin $D$ status and functional visual outcome measures, such as visual acuity, colour vision and visual evoked potentials (VEP), in MS patients. Importantly, while inflammation underlies AMD, in MS the whole afferent visual pathway, including retina, chiasm and tracts, can also be affected by demyelination and axonal degeneration (65).

Another parameter that we took into account in chapter 6, was retinal nerve fibre layer (RNFL) thickness. The RNFL is of interest, because this layer is devoid of myelin and a reduction of RNFL thickness reflects pure axonal damage. Axonal damage plays a major role in MS; it is thought to be the main determinant of permanent disability. Intervention in this pathophysiological finding would therefore be highly relevant. Although neuroprotective mechanisms of vitamin D in the CNS have been suggested (66-68), association studies exploring the effect of high vitamin D status on clinical parameters reflecting neurodegeneration in MS are lacking. To explore this relationship between neurodegeneration and vitamin D status in MS patients, we assessed the correlation between vitamin D status and RNFL thickness. In contrast to our hypothesis we found an inverse association between RNFL thickness and vitamin D status in MS patients. We assumed that the immunomodulatory action of vitamin $D$ plays a key role in preserving the RNFL but other mechanisms may be involved. The relationship between inflammation and neurodegeneration in MS is not fully understood. Neurodegeneration has been observed in normal appearing white matter (NAMW) and in chronic inactive lesions (69). This suggests that neurodegeneration occurs in areas with low inflammatory activity. In addition, in a rat model of MS it was reported that signs of axon degeneration in the optic nerve could be detected before onset of inflammatory infiltration and demyelination of the optic nerve (70). This suggests that early neurodegeneration in MS might be independent of inflammation. Previous studies reporting an association with vitamin D in MS, focused predominantly on inflammatory outcomes, such as relapse rate $(2,71)$ and gadolinium-enhancing brain MRI lesions $(72)$. It could therefore be speculated that high vitamin D status protects against the inflammatory components in MS, but has no effect on neurodegeneration, as such.

Ideally, the relationship between vitamin D and RNFL thickness would be assessed in a vitamin $D$ supplementation study, since causality cannot be derived from crosssectional studies. In addition, assessing brain parenchym volume on MRI in parallel with RNFL thickness may provide more insight on the pathogenesis of neurodegeneration in MS. Nevertheless, our results emphasize the need for further research on the effect of vitamin D on neurodegeneration. Therefore, exploring the effect of vitamin $D$ on neurodegeneration, either as disability progression, brain parenchym volume or RNFL thickness, would be an interesting outcome measure in future vitamin $D$ trials. In addition, exploring the effect of high vitamin $D$ status on isolated inflammatory visual symptoms, such as acute optic neuritis (ON), may be of interest to explore effects of vitamin D on visual outcome measures. 
Fatigue, neuropsychiatric outcome measures and vitamin $D$

The high concurrent prevalence of fatigue, anxiety, depression and cognitive impairment in MS (73), suggests parallels in underlying biological mechanisms. Similar to depression, fatigue, anxiety and cognitive impairment are thought to arise from immune dysfunction and / or damage to the CNS. First, by MRI structural brain changes are noted for depression (74), fatigue (75) and cognitive impairment (76), but not for anxiety (77). The associated structural brain damage, however, does not appear to be the same across the three disorders. Second, the serotonin pathway has been linked to depression $(78,79)$, anxiety $(80)$ and cognitive impairment $(81)$, but not to fatigue. Third, dysregulation of the hypothalamus pituitary adrenal (HPA)-axis has been shown in depression in MS (82), anxiety disorders in non-MS patients (83) as well as in fatigue in MS patients (84), but not in cognitive impairment. Finally, alterations in levels of pro-inflammatory cytokines have been associated with an increase in symptoms of depression (85-87) and in anxiety and irritability (88). MS patients with fatigue have higher TNF- $\alpha$ mRNA expression than those without fatigue (89). In addition, inflammation has been implicated in cognitive decline in elderly (90). Vitamin D may have a direct effect on these symptoms within the CNS, since vitamin D receptor (VDR) and the bio-activating enzymes are expressed in various brain regions, including the limbic system (91). Second, functional neurotransmitter changes have been described in a rat model of gestational vitamin D deficiency (92). Vitamin D supplementation on the other hand, was associated with significantly increased serotonergic activity, in particular in the hypothalamus and hippocampus in the adult rat brain (93). Hence, vitamin D may exert a beneficial effect on the above-mentioned symptoms by stimulating the serotonin pathway. The third hypothesized mechanism of action of vitamin $D$ involves the HPA-axis. Although VDR and CYP27B1 are globally expressed in the CNS, specific regions as the hypothalamus showed in particular intense staining in MS patients (Smolders et al., submitted for publication). In the hypothalamus, CYP24A1 (enzyme responsible for degrading $1,25(\mathrm{OH})_{2} \mathrm{D}$ ) staining is restricted to the paraventricular nucleus (PVN) and the supraoptic nucleus (SON) (Figure 4). The expression of VDR and the metabolizing enzymes in these regions important in HPA-axis functionality may imply a direct biological action. In addition, neurons positive for CYP24A1 comprise the vasopressin and corticotrophin releasing hormone (CRH)-positive neurons (Figure 5). These are important neurons in stimulating the secretion of adrenocorticotrophin hormone (ACTH) in the anterior pituitary gland. Fourth, vitamin D may affect these symptoms by its immunomodulatory effects. The active metabolite $1,25(\mathrm{OH})_{2} \mathrm{D}$ has been described to decrease the production of IFN- $\gamma$ and TNF- $\alpha$, and to increase the production of the anti-inflammatory cytokine IL-10 $(50,94)$. 


\section{CHAPTER 9}

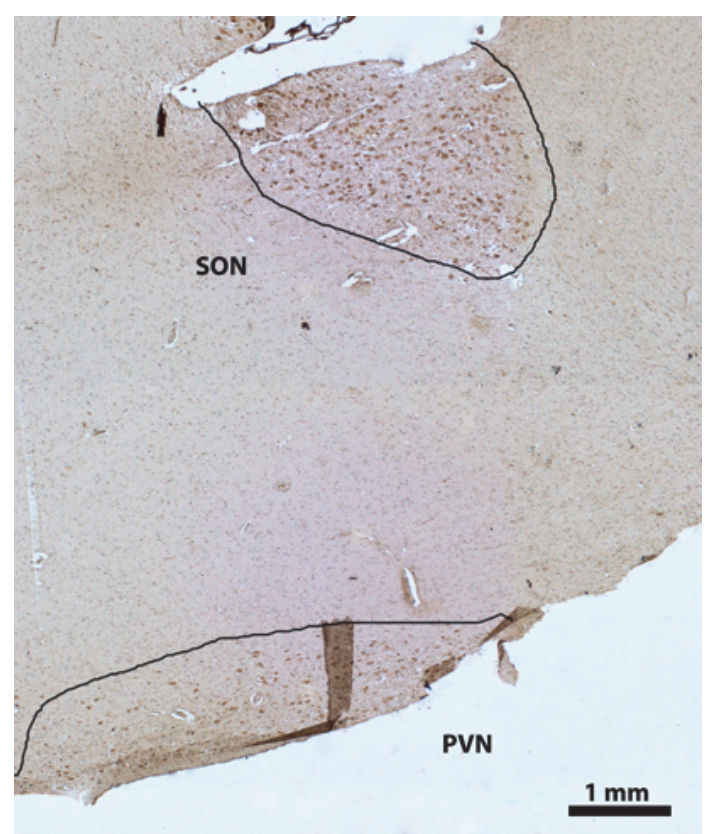

Figure 4. Single staining for CYP24A1 in hypothalamus. Positive staining is restricted to the paraventricular nucleus (PVN) and the supraoptic nucleus (SON). Picture kindly provided by dr. Smolders.



Figure 5. Hypothalamic cortisol releasing hormone (CRH) and vasopressin (VP) positive neurons are positive for Cytochrome P24A1. CRH and VP were stained in the paraventricular nucleus. Picture kindly provided by dr. Smolders. bar $=40 \mu \mathrm{M}$. 
In chapters 7-8 we assessed the association between vitamin D status and depressive symptoms, anxiety, fatigue and cognition. We hypothesized that high vitamin D status is associated with less symptoms of depression, anxiety and fatigue and better cognitive performance. Indeed, in a retrospective study, we found a negative correlation between vitamin D status and depression scores (chapter 7). However, in a prospective study, we observed a negative association with depression only for the highest category of vitamin D (>80nmol/L) (chapter 8). Previous research exploring the association between vitamin $D$ status and fatigue and neuropsychiatric outcomes in healthy and diseased populations shows conflicting results. Some cross-sectional studies have found an association between low levels of serum 25(OH)D and depressive symptoms $(95,96)$, whereas other studies have found no such association $(97,98)$. Similarly, results of randomized controlled trials show conflicting results of vitamin $D$ supplementation on depressive symptoms $(99,100)$. The same conflicting results have been reported for fatigue $(101,102)$ and cognition $(103,104)$, while for anxiety no effect has been reported as measured with State-Trait-Anxiety Inventory (STAI)(104). Those discrepancies in outcomes might have several explanations. First, there is a large variation in power. Inclusion numbers are varying from less than 100 patients with no association $(102,104,105)$ up to 7970 patients where the authors did find an association (95, 106). Remarkably, we found an association between depression and vitamin $D$ status in 59 patients (chapter 7 (107)), but we only could confirm this association in 197 patients when the vitamin D status was $>80 \mathrm{nmol} / \mathrm{L}$ (chapter 8 ). Second, the use of different outcome measures in previous studies could explain the conflicting results. Ideally, DSM-IV criteria should be used to measure depression and anxiety (108). We used the HADS to measure depression and anxiety, because it's a valid questionnaire in a somatic population like MS patients. However unlike DSM-IV criteria, HADS cannot be used to diagnose a depression. This also holds for our questionnaires in fatigue (chapter 7 and 8) and cognitive status (chapter 8). A third explanation for the conflicting results may be the large variation in geographical distribution. Indeed, we found contrasting results in a MS population in South Limburg (chapter 7) compared to a MS population in Southern Australia (chapter 8). This large variation in geographical distribution might involve differences in gene expression, in particular in allele frequencies of human leukocyte antigen (HLA) alleles. An interaction has been suggested between vitamin D and MS risk allele HLA-DR15 by identifying a vitamin D response element in the proximal HLA-DRB1 promotor (109).

Finally, in contrast to our study (chapter 8), none of the before mentioned studies took into account variation in sun exposure. We observed a negative association between reported sun exposure and scores of fatigue and depression in MS patients. Importantly, this association was largely independent of vitamin D status (chapter 8). Ultra violet radiation (UVR) found in sunlight was shown to suppress EAE independent of vitamin D production (110). In the next paragraph we will further elaborate on the 


\section{CHAPTER 9}

possible role of sun exposure in the pathogenesis of depressive symptoms and fatigue in MS patients.

\section{Depressive symptoms, fatigue and sun exposure in MS}

The effect of sun exposure on fatigue and depressive symptoms might be explained by several mechanisms. First, light perception could play a role. Light perception through the eyes induces suppression of pineal melatonin secretion. Melatonin is a hormone that is produced at night and its main function is to synchronise the circadian rhythm (111). The possible anti-depressive effect is probably based on its effect on the central circadian regulation (112). Interestingly, increased melatonin levels have been associated with higher depression scores in patients with long standing MS (113). In addition, nocturnal serum melatonin levels were found to be twice as low in MS patients with a major depression according to DSM-IV criteria than those free of depression (114). Moreover, the mean melatonin level was reported to be significantly lower in suicidal MS patients (115). In addition to its association with depression, dysfunction in melatonin secretion could also play a role in fatigue. Recently dysfunction in melatonin secretion has been suggested to explain reduced sleep efficiency in treatment naive MS patients (116). Likewise, a disturbed sleep-wake cycle in patients with Alzheimer's disease was found to correlate with decreased melatonin levels and a disrupted circadian melatonin rhythm (117).

Alternatively, the effect of sun exposure on depression and fatigue might be explained by the immunomodulatory effects of UVR exposure (reviewed in (118)). Suggested mechanisms of the pro-inflammatory cytokines on depression include actions on the HPA-axis or on neurotransmission. TNF- $\alpha$ was shown to impair the negative feedback loop resulting in hyperactivity of the HPA-axis found in depression (119). Alternatively, cytokines can affect the synthesis, release and reuptake of all neurotransmitters associated with depression, such as serotonin (reviewed in $(120,121)$. The pro-inflammatory cytokine IL- $1 \beta$ was shown to increase serotonin uptake in the brain (122) and IFN- $\alpha$ was shown to decrease expression of serotonin receptor 5HT1A (123), both resulting in a decreased activity of serotonin. Suggested mechanisms of inflammation on fatigue include dysregulation of the suprachiasmatic nucleus (SCN), which controls circadian rhythm. The SCN responds to several pro-inflammatory cytokines, including TNF- $\alpha$ and IFN- $\gamma$. In an electrophysiological study on the action of cytokines in the SCN, a cocktail of TNF- $\alpha$, LPS and IFN- $\gamma$ has been reported to cause a decrease in the frequency of both excitatory and inhibitory currents (124). It can therefore be speculated that an increase in UVR exposure enhances SCN function and thus circadian rhythm by decreasing pro-inflammatory cytokines. Finally, pro-inflammatory cytokines can induce the development of common symptoms of sickness, such as loss of appetite, sleepiness and fatigue, known as cytokine-induced sickness behaviour (125). Suppression of pro-inflammatory cytokines by UVR exposure might thus decrease cyto- 
kine-induced sickness behaviour. Figure 6 summarizes the potential mechanisms of sun exposure on fatigue and depression.

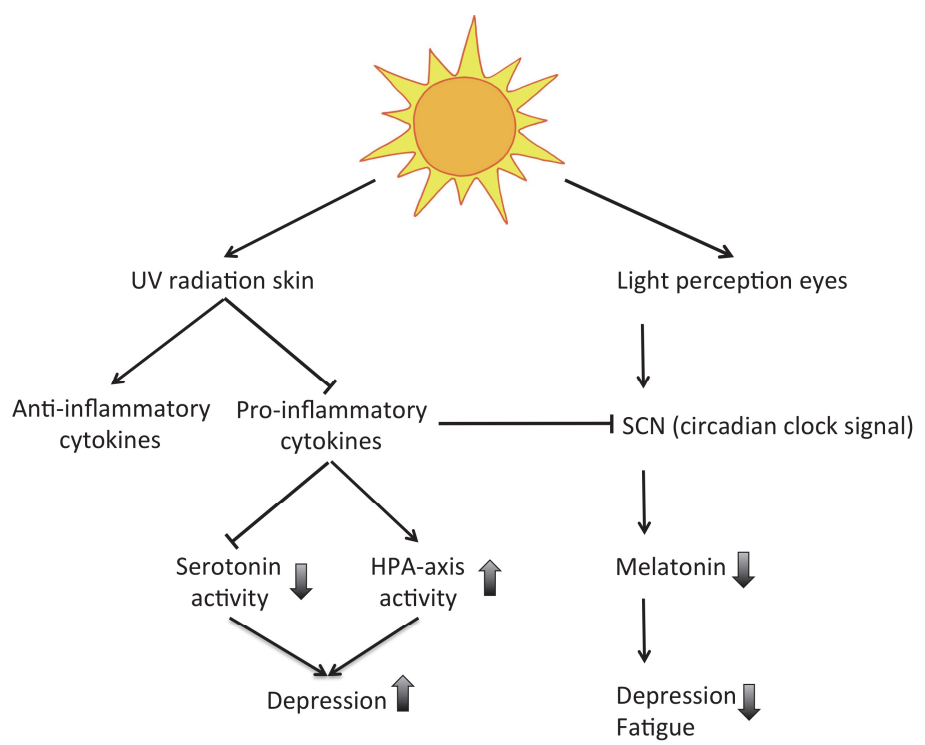

Figure 6. Hypothesized mechanisms of sun exposure on fatigue and depression. An increase in pro-inflammatory cytokines results in lower serotonin activity and higher HPA-axis activity, resulting in more depressive symptoms. UV radiation may decrease circulating pro-inflammatory cytokines. Alternatively, sun light perception through the eyes suppresses melatonin secretion in the pineal gland, which may result in less depressive symptoms and less fatigue.

\section{Conclusion clinical symptoms and vitamin D status in MS}

To conclude this second part of the thesis, we did not observe beneficial effects of vitamin D on visual symptoms of MS (chapter 6 ). Although we observed a negative correlation between 25(OH)D status and depressive symptoms in a retrospective study (chapter 7), in a prospective cohort study we could not replicate this. However, we found that higher levels of reported sun exposure, and not vitamin D, were associated with less depressive symptoms and levels of fatigue, after mutually adjusting for each other (chapter 8). This suggests an effect of sun exposure largely outside the vitamin D pathway. Although there was some evidence that 25(OH)D levels above $80 \mathrm{nmol} / \mathrm{L}$ were negatively associated with depressive symptoms, this association was not significant after adjustment for reported sun exposure. Therefore, vitamin D supplementation trials will have to confirm whether high levels of vitamin $D$ have the capacity to reduce these symptoms in MS, or that UVR exposure is necessary. Underlying mecha- 


\section{CHAPTER 9}

nisms for the observed associations between the clinical symptoms and sun exposure or vitamin $\mathrm{D}$ might in particular be linked to the inflammatory response.

\section{Future directions and concluding remarks}

In this thesis, we observed that the immunomodulatory effects of vitamin $D$ found in vitro (chapter 2), are not per se associated with immunomodulatory effects ex vivo (chapter 3-4). We did not observe associations between vitamin D status and clinical benefits in MS patients (chapter 6-8). This generates questions and provides new directions for future vitamin $D$ research in MS.

Although we did not find a correlation between vitamin D status and B cell subsets or the percentage of Breg cells in healthy controls and MS patients, this does not exclude a more discrete effect of vitamin D on B cells. Likewise, poor vitamin D status has been associated with decreased suppressive function of Treg cells, but not with numbers of Treg cells (126). Therefore, high levels of vitamin D may affect function of Breg cells, qualified by their ability to suppress $\mathrm{T}$ cell proliferation or cytokine production. In addition, since $B$ cell subsets and function are getting better described, there are additional B cell subsets to explore. Finally, in this thesis we explored peripheral B cell subsets, while it would be interesting to explore the effect of vitamin D on B cells in CSF next to the peripheral compartment.

We did not include genetic polymorphisms in our studies, while vitamin D status was shown to be under genetic influence $(127,128)$. Studies exploring the risk of MS with genes that are involved in vitamin D metabolism (VDR, Cyp27B1, DBP and CyP24A1) show varying results $(129,130)$. However, it has been suggested that 25(OH)D levels and the VDR interaction are only relevant in HLA-DRB1*15 positive individuals (131). Alternatively, polymorphisms in genes involved in the vitamin D effector pathway may impair the effect of vitamin $D$ supplementation or sun exposure. This is underlined by the observation that Sardinia is a rare exception to the inverse correlation between ambient UV light and MS prevalence $(132,133)$, which has been suggested to arise from an IFN- $\gamma$ gene mutation $(134,135)$. In addition, in EAE, it was shown that IFN- $\gamma$ KO mice, did not profit from vitamin D treatment (136). Hence, inclusion of genetics next to immunomodulatory outcomes is important in vitamin $D$ supplementation trials.

Few studies include both sun exposure and vitamin D status to explore independent associations with MS. It is possible that moderate sun exposure and vitamin $D$ supplementation may be complementary for prevention or disease management of MS. A recent Australian study concluded that sun exposure and vitamin D status have independent roles in the disease pathogenesis of MS (137). However, the majority of vitamin $D$ is usually UVR-generated. It can therefore be speculated that previous studies showing an association with vitamin $D$ are potentially showing an epiphenomenon 
of sun exposure. Future trials that explore clinical outcomes of vitamin D supplementation in both winter and in summer may help us better understand the possible cumulative effects of vitamin $D$ supplementation upon sun exposure. In addition, vitamin $D$ supplementation trials should include measures of sun exposure by including either detailed questionnaires about sun exposure (chapter 8 ) or with polysulfone badges (138). This may provide more insight into a true effect of vitamin D supplementation, or that disease is in fact associated with sun exposure. However, recommending sun exposure is a delicate subject, because heat by sun light can make MS symptoms worse $(139,140)$ and of the known adverse effects of UV radiation (141). At present, accurate advice that balances the two aspects of UV exposure cannot be given. For this purpose, it is important to explore which doses of UV exposure are beneficial without inducing the deleterious effects of UV radiation. The committee of the Dutch Cancer Society advices to moderate sun exposure. The committee does postulate that vitamin D may play an important role in the prevention of cancer other than skin cancers. In particular $25(\mathrm{OH}) \mathrm{D}$ levels higher than $80 \mathrm{nmol} / \mathrm{L}$ are thought to be beneficial, which in the Netherlands is achievable from 15 to 30 minutes of sun exposure on head, hands and arms per day. However, an independent beneficial effect of sun exposure is not considered in their advice (142).

Previous research in vitamin D and MS has focused predominantly on inflammation. Inflammation may also be one of the important underlying biological mechanisms in clinical symptoms as depression, anxiety, fatigue and cognition. Yet other outcome measures, such as neurodegeneration, are also of interest to explore. In this thesis we observed that RNFL thickness and depressive symptoms in particular are interesting outcome measures in vitamin D supplementation trials. However, causality cannot be derived from our studies. To confirm our finding of a negative association between high vitamin D status and decreased RNFL thickness, the association with whole brain parenchym volume, which is considered the golden standard for axonal damage, should be explored. In addition, other outcomes reflecting neurodegeneration, such as disease progression, should deserve more attention.

To conclude, there is currently insufficient RCT evidence to recommend vitamin D supplementation to control symptoms in MS patients. "There is no harm in trying" doesn't apply until proven otherwise. There is a considerable amount of evidence that a poor vitamin D status in MS should be supplemented with moderate amounts of vitamin D to maintain a healthy calcium metabolism (chapter 5 (143)). However, with clinical trials running, it is important to expand the exploration on the effect of vitamin D to a large scale of MS symptoms. Moreover, it should be excluded that the observed clinical associations with vitamin D are not an epiphenomenon of sun exposure. 


\section{CHAPTER 9}

\section{References}

1. Ascherio A, Munger KL, Simon KC. Vitamin D and multiple sclerosis. Lancet Neurol. 2010 Jun;9(6):599612.

2. Simpson S, Jr., Taylor B, Blizzard L, et al. Higher 25-hydroxyvitamin D is associated with lower relapse risk in multiple sclerosis. Ann Neurol. 2010 Aug;68(2):193-203.

3. Smolders J, Damoiseaux J, Menheere P, et al. Vitamin D as an immune modulator in multiple sclerosis, a review. J Neuroimmunol. 2008 Feb;194(1-2):7-17.

4. Hauser $\mathrm{SL}$, Waubant $\mathrm{E}$, Arnold DL, et al. B-cell depletion with rituximab in relapsing-remitting multiple sclerosis. N Engl J Med. 2008 Feb 14;358(7):676-88.

5. Trebst C, Bronzlik P, Kielstein JT, et al. Immunoadsorption therapy for steroid-unresponsive relapses in patients with multiple sclerosis. Blood Purif. 2012;33(1-3):1-6.

6. Kabat EA, Glusman M, Knaub V. Quantitative estimation of the albumin and gamma globulin in normal and pathologic cerebrospinal fluid by immunochemical methods. Am J Med. 1948 May;4(5):653-62.

7. Serafini B, Rosicarelli B, Magliozzi R, et al. Detection of ectopic B-cell follicles with germinal centers in the meninges of patients with secondary progressive multiple sclerosis. Brain Pathol. 2004 Apr;14(2):164-74.

8. Baumgarth N. A two-phase model of B-cell activation. Immunol Rev. 2000 Aug;176:171-80.

9. Good KL, Avery DT, Tangye SG. Resting human memory B cells are intrinsically programmed for enhanced survival and responsiveness to diverse stimuli compared to naive B cells. J Immunol. 2009 Jan 15;182(2):890-901.

10. Bar-Or A, Oliveira EM, Anderson DE, et al. Immunological memory: contribution of memory B cells expressing costimulatory molecules in the resting state. J Immunol. 2001 Nov 15;167(10):5669-77.

11. Lovett-Racke AE, Trotter JL, Lauber J, et al. Decreased dependence of myelin basic protein-reactive $T$ cells on CD28-mediated costimulation in multiple sclerosis patients. A marker of activated/memory $T$ cells. J Clin Invest. 1998 Feb 15;101(4):725-30.

12. Genc K, Dona DL, Reder AT. Increased $\mathrm{CD} 8\left(^{+}\right)$B cells in active multiple sclerosis and reversal by interferon beta-1b therapy. J Clin Invest. 1997 Jun 1;99(11):2664-71.

13. Bar-Or A, Fawaz L, Fan B, et al. Abnormal B-cell cytokine responses a trigger of T-cell-mediated disease in MS? Ann Neurol. 2010 Apr;67(4):452-61.

14. Duddy M, Niino M, Adatia F, et al. Distinct effector cytokine profiles of memory and naive human B cell subsets and implication in multiple sclerosis. J Immunol. 2007 May 15;178(10):6092-9.

15. Chesnut RW, Grey HM. Studies on the capacity of B cells to serve as antigen-presenting cells. J Immunol. 1981 Mar;126(3):1075-9.

16. Krieger Jl, Grammer SF, Grey HM, et al. Antigen presentation by splenic B cells: resting B cells are ineffective, whereas activated B cells are effective accessory cells for T cell responses. J Immunol. 1985 Nov;135(5):2937-45.

17. Jiang $W$, Lederman MM, Harding CV, et al. TLR9 stimulation drives naive B cells to proliferate and to attain enhanced antigen presenting function. Eur J Immunol. 2007 Aug;37(8):2205-13.

18. Carpenter EL, Mick R, Ruter J, et al. Activation of human B cells by the agonist CD40 antibody CP870,893 and augmentation with simultaneous toll-like receptor 9 stimulation. J Transl Med. 2009;7:93.

19. Reichardt $\mathrm{P}$, Dornbach $\mathrm{B}$, Rong $\mathrm{S}$, et al. Naive $\mathrm{B}$ cells generate regulatory $\mathrm{T}$ cells in the presence of a mature immunologic synapse. Blood. 2007 Sep 1;110(5):1519-29.

20. Ireland S, Monson N. Potential impact of B cells on T cell function in multiple sclerosis. Mult Scler Int. 2011;2011:423971.

21. Lemoine $S$, Morva $A$, Youinou $P$, et al. Human $T$ cells induce their own regulation through activation of B cells. J Autoimmun. 2011 May;36(3-4):228-38. 
22. Blair PA, Norena LY, Flores-Borja F, et al. CD19( $\left.{ }^{+}\right)$CD24(hi)CD38(hi) B cells exhibit regulatory capacity in healthy individuals but are functionally impaired in systemic Lupus Erythematosus patients. Immunity. 2010 Jan 29;32(1):129-40.

23. Lampropoulou V, Calderon-Gomez E, Roch T, et al. Suppressive functions of activated B cells in autoimmune diseases reveal the dual roles of Toll-like receptors in immunity. Immunol Rev. 2010 Jan;233(1):146-61.

24. Hirotani M, Niino M, Fukazawa T, et al. Decreased IL-10 production mediated by Toll-like receptor 9 in B cells in multiple sclerosis. J Neuroimmunol. 2010 Apr 15;221(1-2):95-100.

25. Lampropoulou V, Hoehlig K, Roch T, et al. TLR-activated B cells suppress T cell-mediated autoimmunity. J Immunol. 2008 Apr 1;180(7):4763-73.

26. Rieger A, Bar-Or A. B-cell-derived interleukin-10 in autoimmune disease: regulating the regulators. Nat Rev Immunol. 2008 Jun;8(6):486-7.

27. Niino $M$, Bodner $C$, Simard $M L$, et al. Natalizumab effects on immune cell responses in multiple sclerosis. Ann Neurol. 2006 May;59(5):748-54.

28. Lee-Chang C, Zephir H, Top I, et al. B-cell subsets up-regulate alpha4 integrin and accumulate in the cerebrospinal fluid in clinically isolated syndrome suggestive of multiple sclerosis onset. Neurosci Lett. 2011 Jan 10;487(3):273-7.

29. Cepok S, Rosche B, Grummel V, et al. Short-lived plasma blasts are the main B cell effector subset during the course of multiple sclerosis. Brain. 2005 Jul;128(Pt 7):1667-76.

30. Cepok S, von Geldern G, Grummel V, et al. Accumulation of class switched IgD-IgM- memory B cells in the cerebrospinal fluid during neuroinflammation. J Neuroimmunol. 2006 Nov;180(1-2):33-9.

31. Ragheb S, Li Y, Simon K, et al. Multiple sclerosis: BAFF and CXCL13 in cerebrospinal fluid. Mult Scler. $2011 \mathrm{Jul} ; 17(7): 819-29$.

32. Legler DF, Loetscher M, Roos RS, et al. B cell-attracting chemokine 1, a human CXC chemokine expressed in lymphoid tissues, selectively attracts B lymphocytes via BLR1/CXCR5. J Exp Med. 1998 Feb 16;187(4):655-60.

33. Schneider P. The role of APRIL and BAFF in lymphocyte activation. Curr Opin Immunol. 2005 Jun;17(3):282-9.

34. Krumbholz M, Theil D, Derfuss $T$, et al. BAFF is produced by astrocytes and up-regulated in multiple sclerosis lesions and primary central nervous system lymphoma. J Exp Med. 2005 Jan 17;201(2):195200.

35. Badr G, Borhis G, Lefevre EA, et al. BAFF enhances chemotaxis of primary human B cells: a particular synergy between BAFF and CXCL13 on memory B cells. Blood. 2008 Mar 1;111(5):2744-54.

36. Magliozzi R, Howell $O$, Vora A, et al. Meningeal B-cell follicles in secondary progressive multiple sclerosis associate with early onset of disease and severe cortical pathology. Brain. $2007 \mathrm{Apr} ; 130$ (Pt 4):1089-104.

37. Qin $Y$, Duquette $P$, Zhang $Y$, et al. Intrathecal B-cell clonal expansion, an early sign of humoral immunity, in the cerebrospinal fluid of patients with clinically isolated syndrome suggestive of multiple sclerosis. Lab Invest. 2003 Jul;83(7):1081-8.

38. Cross $\mathrm{AH}$, Stark JL. Humoral immunity in multiple sclerosis and its animal model, experimental autoimmune encephalomyelitis. Immunol Res. 2005;32(1-3):85-97.

39. Srivastava R, Aslam M, Kalluri SR, et al. Potassium channel KIR4.1 as an immune target in multiple sclerosis. N Engl J Med. 2012 Jul 12;367(2):115-23.

40. Boster A, Ankeny DP, Racke MK. The potential role of B cell-targeted therapies in multiple sclerosis. Drugs. 2010 Dec 24;70(18):2343-56.

41. Mann MK, Maresz K, Shriver LP, et al. B cell regulation of $\mathrm{CD} 4^{+} \mathrm{CD} 25^{+}$T regulatory cells and IL-10 via B7 is essential for recovery from experimental autoimmune encephalomyelitis. J Immunol. 2007 Mar $15 ; 178(6): 3447-56$. 


\section{CHAPTER 9}

42. Baumgarth $\mathrm{N}$. The double life of a B-1 cell: self-reactivity selects for protective effector functions. Nat Rev Immunol. 2010 Jan;11(1):34-46.

43. Shaw PX, Horkko S, Chang MK, et al. Natural antibodies with the T15 idiotype may act in atherosclerosis, apoptotic clearance, and protective immunity. J Clin Invest. 2000 Jun;105(12):1731-40.

44. Manson JJ, Mauri C, Ehrenstein MR. Natural serum IgM maintains immunological homeostasis and prevents autoimmunity. Springer Semin Immunopathol. 2005 Mar;26(4):425-32.

45. van Leeuwen $M$, Damoiseaux J, Duijvestijn A, et al. The therapeutic potential of targeting B cells and anti-oxLDL antibodies in atherosclerosis. Autoimmun Rev. 2009 Sep;9(1):53-7.

46. Berland R, Wortis $\mathrm{HH}$. Origins and functions of B-1 cells with notes on the role of CD5. Annu Rev Immunol. 2002;20:253-300.

47. Griffin DO, Holodick NE, Rothstein TL. Human B1 cells in umbilical cord and adult peripheral blood express the novel phenotype CD20+ $\mathrm{CD}^{2} 7^{+} \mathrm{CD}^{+} 3^{+} \mathrm{CD} 70$. J Exp Med. 2011 Jan 17;208(1):67-80.

48. Griffin DO, Rothstein TL. A small $\mathrm{CD} 11 \mathrm{~b}\left({ }^{+}\right)$human B1 cell subpopulation stimulates $\mathrm{T}$ cells and is expanded in lupus. J Exp Med. 2011 Dec 19;208(13):2591-8.

49. Villar LM, Garcia-Sanchez MI, Costa-Frossard L, et al. Immunological markers of optimal response to natalizumab in multiple sclerosis. Arch Neurol. 2012 Feb;69(2):191-7.

50. Peelen $E$, Knippenberg $S$, Muris $A H$, et al. Effects of vitamin $D$ on the peripheral adaptive immune system: a review. Autoimmun Rev. 2011 Oct;10(12):733-43.

51. Chen S, Sims GP, Chen XX, et al. Modulatory effects of 1,25-dihydroxyvitamin D3 on human B cell differentiation. J Immunol. 2007 Aug 1;179(3):1634-47.

52. Chen WC, Vayuvegula B, Gupta S. 1,25-Dihydroxyvitamin D3-mediated inhibition of human B cell differentiation. Clin Exp Immunol. 1987 Sep;69(3):639-46.

53. Heine G, Anton K, Henz BM, et al. 1alpha,25-dihydroxyvitamin D3 inhibits anti-CD40 plus IL-4-mediated IgE production in vitro. Eur J Immunol. 2002 Dec;32(12):3395-404.

54. Heine G, Niesner U, Chang HD, et al. 1,25-dihydroxyvitamin D(3) promotes IL-10 production in human B cells. Eur J Immunol. 2008 Aug;38(8):2210-8.

55. Knippenberg S, Smolders J, Thewissen M, et al. Effect of vitamin D(3) supplementation on peripheral B cell differentiation and isotype switching in patients with multiple sclerosis. Mult Scler. 2011 Dec;17(12):1418-23.

56. Knippenberg S, Peelen E, Smolders J, et al. Reduction in IL-10 producing B cells (Breg) in multiple sclerosis is accompanied by a reduced naive/memory Breg ratio during a relapse but not in remission. J Neuroimmunol. 2012 Oct 28;239(1-2):80-6.

57. Haas J, Bekeredjian-Ding I, Milkova $\mathrm{M}$, et al. B cells undergo unique compartmentalized redistribution in multiple sclerosis. J Autoimmun. 2011 Dec;37(4):289-99.

58. Smolders J, Peelen E, Thewissen M, et al. Safety and T cell modulating effects of high dose vitamin D3 supplementation in multiple sclerosis. PLoS One. 2010;5(12):e15235.

59. Binard A, Le Pottier L, Devauchelle-Pensec V, et al. Is the blood B-cell subset profile diagnostic for Sjogren syndrome? Ann Rheum Dis. 2009 Sep;68(9):1447-52.

60. Sanz I, Wei C, Lee FE, et al. Phenotypic and functional heterogeneity of human memory B cells. Semin Immunol. 2008 Feb;20(1):67-82.

61. Smolders J, Moen SM, Damoiseaux J, et al. Vitamin D in the healthy and inflamed central nervous system: access and function. J Neurol Sci. 2011 Dec 15;311(1-2):37-43.

62. Millen $A E$, Voland $R$, Sondel $S A$, et al. Vitamin $D$ status and early age-related macular degeneration in postmenopausal women. Arch Ophthalmol. 2011 Apr;129(4):481-9.

63. Resnikoff $S$, Pascolini D, Etya'ale D, et al. Global data on visual impairment in the year 2002. Bull World Health Organ. 2004 Nov;82(11):844-51.

64. Hageman GS, Luthert PJ, Victor Chong NH, et al. An integrated hypothesis that considers drusen as biomarkers of immune-mediated processes at the RPE-Bruch's membrane interface in aging and agerelated macular degeneration. Prog Retin Eye Res. 2001 Nov;20(6):705-32. 
65. Arnold AC. Evolving management of optic neuritis and multiple sclerosis. Am J Ophthalmol. [Review]. 2005 Jun;139(6):1101-8.

66. Brewer LD, Thibault V, Chen KC, et al. Vitamin D hormone confers neuroprotection in parallel with downregulation of L-type calcium channel expression in hippocampal neurons. J Neurosci. 2001 Jan 1;21(1):98-108.

67. Dursun E, Gezen-Ak D, Yilmazer S. A novel perspective for Alzheimer's disease: vitamin D receptor suppression by amyloid-beta and preventing the amyloid-beta induced alterations by vitamin $D$ in cortical neurons. J Alzheimers Dis. 2011;23(2):207-19.

68. Wang JY, Wu JN, Cherng TL, et al. Vitamin $\mathrm{D}(3)$ attenuates 6-hydroxydopamine-induced neurotoxicity in rats. Brain Res. 2001 Jun 15;904(1):67-75.

69. Kornek B, Storch MK, Weissert R, et al. Multiple sclerosis and chronic autoimmune encephalomyelitis: a comparative quantitative study of axonal injury in active, inactive, and remyelinated lesions. Am J Pathol. 2000 Jul;157(1):267-76.

70. Fairless R, Williams SK, Hoffmann DB, et al. Preclinical retinal neurodegeneration in a model of multiple sclerosis. J Neurosci. 2012 Apr 18;32(16):5585-97.

71. Smolders J, Menheere $P$, Kessels A, et al. Association of vitamin D metabolite levels with relapse rate and disability in multiple sclerosis. Mult Scler. 2008 Nov;14(9):1220-4.

72. Mowry E WE, McCulloch C, Okuda D, Evangelista A, Lincoln R, Gourraud P.A, Brenneman D, Owen M, Qualley P, Bucci M, Oksenberg J, Hauser S, Pelletier D. Higher vitamin D levels are associated with the development of fewer T2- and gadolinium-enhancing brain MRI lesions in multiple sclerosis. Congress of the European and Americas Committees for Treatment and Research in Multiple Sclerosis; Amsterdam: Multiple Sclerosis Journal, Volume 17, Supplement 10; 2011. p. S48.

73. Wood B, van der Mei I, Ponsonby AL, et al. Prevalence and concurrence of anxiety, depression and fatigue over time in multiple sclerosis. Mult Scler. 2012 Jun 22.

74. Feinstein $\mathrm{A}$, Roy $\mathrm{P}$, Lobaugh $\mathrm{N}$, et al. Structural brain abnormalities in multiple sclerosis patients with major depression. Neurology. 2004 Feb 24;62(4):586-90.

75. Sepulcre J, Masdeu JC, Goni J, et al. Fatigue in multiple sclerosis is associated with the disruption of frontal and parietal pathways. Mult Scler. 2009 Mar;15(3):337-44.

76. Horakova D, Kalincik T, Dusankova JB, et al. Clinical correlates of grey matter pathology in multiple sclerosis. BMC Neurol. 2012;12:10.

77. Di Legge S, Piattella MC, Pozzilli C, et al. Longitudinal evaluation of depression and anxiety in patients with clinically isolated syndrome at high risk of developing early multiple sclerosis. Mult Scler. 2003 Jun;9(3):302-6.

78. Markianos M, Sfagos C. Altered serotonin uptake kinetics in multiple sclerosis. J Neurol. 1988 Mar;235(4):236-7.

79. Ruhe HG, Mason NS, Schene AH. Mood is indirectly related to serotonin, norepinephrine and dopamine levels in humans: a meta-analysis of monoamine depletion studies. Mol Psychiatry. 2007 Apr;12(4):331-59.

80. Caspi A, Sugden K, Moffitt TE, et al. Influence of life stress on depression: moderation by a polymorphism in the 5-HTT gene. Science. 2003 Jul 18;301(5631):386-9.

81. Geldenhuys WJ, Van der Schyf CJ. The serotonin 5-HT6 receptor: a viable drug target for treating cognitive deficits in Alzheimer's disease. Expert Rev Neurother. 2009 Jul;9(7):1073-85.

82. Gold SM, Kruger S, Ziegler KJ, et al. Endocrine and immune substrates of depressive symptoms and fatigue in multiple sclerosis patients with comorbid major depression. J Neurol Neurosurg Psychiatry. 2011 Jul;82(7):814-8.

83. Abelson JL, Curtis GC. Hypothalamic-pituitary-adrenal axis activity in panic disorder. 24-hour secretion of corticotropin and cortisol. Arch Gen Psychiatry. 1996 Apr;53(4):323-31.

84. Gottschalk M, Kumpfel T, Flachenecker P, et al. Fatigue and regulation of the hypothalamo-pituitaryadrenal axis in multiple sclerosis. Arch Neurol. 2005 Feb;62(2):277-80. 


\section{CHAPTER 9}

85. Dowlati Y, Herrmann N, Swardfager W, et al. A meta-analysis of cytokines in major depression. Biol Psychiatry. 2010 Mar 1;67(5):446-57.

86. Howren MB, Lamkin DM, Suls J. Associations of depression with C-reactive protein, IL-1, and IL-6: a meta-analysis. Psychosom Med. 2009 Feb;71(2):171-86.

87. Maes M. Depression is an inflammatory disease, but cell-mediated immune activation is the key component of depression. Prog Neuropsychopharmacol Biol Psychiatry. 2011 Apr 29;35(3):664-75.

88. Hou R, Baldwin DS. A neuroimmunological perspective on anxiety disorders. Hum Psychopharmacol. 2012 Jan;27(1):6-14.

89. Flachenecker $\mathrm{P}$, Bihler I, Weber $\mathrm{F}$, et al. Cytokine mRNA expression in patients with multiple sclerosis and fatigue. Mult Scler. 2004 Apr;10(2):165-9.

90. Corona AW, Fenn AM, Godbout JP. Cognitive and behavioral consequences of impaired immunoregulation in aging. J Neuroimmune Pharmacol. 2012 Mar;7(1):7-23.

91. Eyles DW, Smith S, Kinobe R, et al. Distribution of the vitamin D receptor and 1 alpha-hydroxylase in human brain. J Chem Neuroanat. 2005 Jan;29(1):21-30.

92. Tenenhouse A, Warner M, Commissiong JW. Neurotransmitters in the CNS of the vitamin D deficient, hypocalcemic rat. Neurochem Int. 1991;18(2):249-55.

93. Tekes K, Gyenge M, Folyovich A, et al. Influence of neonatal vitamin A or vitamin D treatment on the concentration of biogenic amines and their metabolites in the adult rat brain. Horm Metab Res. 2009 Apr;41(4):277-80.

94. Kubera $\mathrm{M}$, Lin $\mathrm{AH}$, Kenis $\mathrm{G}$, et al. Anti-Inflammatory effects of antidepressants through suppression of the interferon-gamma/interleukin-10 production ratio. J Clin Psychopharmacol. 2001 Apr;21(2):199206.

95. Ganji V, Milone C, Cody MM, et al. Serum vitamin D concentrations are related to depression in young adult US population: the Third National Health and Nutrition Examination Survey. Int Arch Med. 2010;3:29.

96. Kjaergaard $M$, Joakimsen $R$, Jorde R. Low serum 25-hydroxyvitamin D levels are associated with depression in an adult Norwegian population. Psychiatry Res. 2011 Dec 30;190(2-3):221-5.

97. Pan A, Lu L, Franco OH, et al. Association between depressive symptoms and 25-hydroxyvitamin $D$ in middle-aged and elderly Chinese. J Affect Disord. 2009 Nov;118(1-3):240-3.

98. Schneider B, Weber B, Frensch A, et al. Vitamin D in schizophrenia, major depression and alcoholism. J Neural Transm. 2000;107(7):839-42.

99. Jorde R, Sneve M, Figenschau Y, et al. Effects of vitamin D supplementation on symptoms of depression in overweight and obese subjects: randomized double blind trial. J Intern Med. 2008 Dec;264(6):599609.

100. Kjaergaard $M$, Waterloo $K$, Wang $C E$, et al. Effect of vitamin D supplement on depression scores in people with low levels of serum 25-hydroxyvitamin D: nested case-control study and randomised clinical trial. Br J Psychiatry. 2012 Jul 12.

101. Askmark H, Haggard L, Nygren I, et al. Vitamin D deficiency in patients with myasthenia gravis and improvement of fatigue after supplementation of vitamin D3: a pilot study. Eur J Neurol. 2012 Jun 4.

102. Kampman MT, Steffensen LH, Mellgren SI, et al. Effect of vitamin D3 supplementation on relapses, disease progression, and measures of function in persons with multiple sclerosis: exploratory outcomes from a double-blind randomised controlled trial. Mult Scler. 2012 Aug;18(8):1144-51.

103. Annweiler C, Fantino B, Gautier J, et al. Cognitive effects of vitamin D supplementation in older outpatients visiting a memory clinic: a pre-post study. J Am Geriatr Soc. 2012 Apr;60(4):793-5.

104. Dean AJ, Bellgrove MA, Hall T, et al. Effects of vitamin D supplementation on cognitive and emotional functioning in young adults--a randomised controlled trial. PLoS One. 2011;6(11):e25966.

105. Stockton KA, Kandiah DA, Paratz JD, et al. Fatigue, muscle strength and vitamin D status in women with systemic lupus erythematosus compared with healthy controls. Lupus. 2012 Mar;21(3):271-8. 
106. Ruiz-Irastorza G, Gordo S, Olivares N, et al. Changes in vitamin D levels in patients with systemic lupus erythematosus: Effects on fatigue, disease activity, and damage. Arthritis Care Res (Hoboken). 2010 Aug;62(8):1160-5.

107. Knippenberg S, Bol Y, Damoiseaux J, et al. Vitamin D status in patients with MS is negatively correlated with depression, but not with fatigue. Acta Neurol Scand. 2012 Sep;124(3):171-5.

108. Association AP. Diagnostic and Statistical Manual of Mental Disorders. fourth ed. Washington D.C.: American Psychiatric association 2001.

109. Ramagopalan SV, Maugeri NJ, Handunnetthi L, et al. Expression of the multiple sclerosis-associated MHC class II Allele HLA-DRB1*1501 is regulated by vitamin D. PLoS Genet. 2009 Feb;5(2):e1000369.

110. Becklund BR, Severson KS, Vang SV, et al. UV radiation suppresses experimental autoimmune encephalomyelitis independent of vitamin D production. Proc Natl Acad Sci U S A. [Research Support, Non-U.S. Gov't]. 2010 Apr 6;107(14):6418-23.

111. Claustrat B, Brun J, Chazot G. The basic physiology and pathophysiology of melatonin. Sleep Med Rev. 2005 Feb;9(1):11-24.

112. Srinivasan V, Pandi-Perumal SR, Trakht I, et al. Pathophysiology of depression: role of sleep and the melatonergic system. Psychiatry Res. 2009 Feb 28;165(3):201-14.

113. Haase CG, Tinnefeld M, Faustmann PM. The influence of immunomodulation on psychoneuroimmunological functions in benign multiple sclerosis. Neuroimmunomodulation. 2004;11(6):36572.

114. Akpinar Z, Tokgoz S, Gokbel H, et al. The association of nocturnal serum melatonin levels with major depression in patients with acute multiple sclerosis. Psychiatry Res. 2008 Nov 30;161(2):253-7.

115. Sandyk R, Awerbuch GI. Nocturnal melatonin secretion in suicidal patients with multiple sclerosis. Int $J$ Neurosci. 1993 Jul-Aug;71(1-4):173-82.

116. Melamud L, Golan D, Luboshitzky R, et al. Melatonin dysregulation, sleep disturbances and fatigue in multiple sclerosis. J Neurol Sci. 2011 Mar 15;314(1-2):37-40.

117. Wu YH, Feenstra MG, Zhou JN, et al. Molecular changes underlying reduced pineal melatonin levels in Alzheimer disease: alterations in preclinical and clinical stages. J Clin Endocrinol Metab. 2003 Dec;88(12):5898-906.

118. Hart PH, Gorman S, Finlay-Jones JJ. Modulation of the immune system by UV radiation: more than just the effects of vitamin D? Nat Rev Immunol. 2011 Sep;11(9):584-96.

119. Wichers MC, Kenis G, Koek GH, et al. Interferon-alpha-induced depressive symptoms are related to changes in the cytokine network but not to cortisol. J Psychosom Res. 2007 Feb;62(2):207-14.

120. Dunn AJ. Effects of cytokines and infections on brain neurochemistry. Clin Neurosci Res. 2006 Aug;6(12):52-68.

121. Miller AH, Maletic V, Raison CL. Inflammation and its discontents: the role of cytokines in the pathophysiology of major depression. Biol Psychiatry. 2009 May 1;65(9):732-41.

122. Zhu CB, Lindler KM, Owens AW, et al. Interleukin-1 receptor activation by systemic lipopolysaccharide induces behavioral despair linked to MAPK regulation of CNS serotonin transporters. Neuropsychopharmacology. 2010 Dec;35(13):2510-20.

123. Cai W, Khaoustov $\mathrm{VI}$, Xie Q, et al. Interferon-alpha-induced modulation of glucocorticoid and serotonin receptors as a mechanism of depression. J Hepatol. 2005 Jun;42(6):880-7.

124. Lundkvist GB, Hill RH, Kristensson K. Disruption of circadian rhythms in synaptic activity of the suprachiasmatic nuclei by African trypanosomes and cytokines. Neurobiol Dis. 2002 Oct;11(1):20-7.

125. Dantzer R, Kelley KW. Twenty years of research on cytokine-induced sickness behavior. Brain Behav Immun. 2007 Feb;21(2):153-60.

126. Smolders J, Thewissen $\mathrm{M}$, Peelen $\mathrm{E}$, et al. Vitamin D status is positively correlated with regulatory $\mathrm{T}$ cell function in patients with multiple sclerosis. PLoS One. 2009;4(8):e6635. 


\section{CHAPTER 9}

127. Orton SM, Morris AP, Herrera BM, et al. Evidence for genetic regulation of vitamin $D$ status in twins with multiple sclerosis. The American journal of clinical nutrition. [Research Support, Non-U.S. Gov't Twin Study]. 2008 Aug;88(2):441-7.

128. Smolders J, Damoiseaux J, Menheere P, et al. Fok-I vitamin D receptor gene polymorphism (rs10735810) and vitamin D metabolism in multiple sclerosis. J Neuroimmunol. 2009 Feb 15;207(12):117-21.

129. Orton SM, Ramagopalan SV, Para AE, et al. Vitamin D metabolic pathway genes and risk of multiple sclerosis in Canadians. Journal of the neurological sciences. [Research Support, Non-U.S. Gov't]. 2011 Jun 15;305(1-2):116-20.

130. Sawcer S, Hellenthal G, Pirinen M, et al. Genetic risk and a primary role for cell-mediated immune mechanisms in multiple sclerosis. Nature. [Research Support, N.I.H., Extramural Research Support, Non-U.S. Gov't]. 2011 Aug 11;476(7359):214-9.

131. Handel AE, Ramagopalan SV. Vitamin D and multiple sclerosis: an interaction between genes and environment. Multiple sclerosis. [Comment Editorial]. 2012 Jan;18(1):2-4.

132. Pugliatti M, Cossu $P$, Sotgiu $S$, et al. Clustering of multiple sclerosis, age of onset and gender in Sardinia. J Neurol Sci. 2009 Nov 15;286(1-2):6-13.

133. Pugliatti M, Sotgiu S, Solinas G, et al. Multiple sclerosis epidemiology in Sardinia: evidence for a true increasing risk. Acta Neurol Scand. 2001 Jan;103(1):20-6.

134. Goris A, Heggarty S, Marrosu MG, et al. Linkage disequilibrium analysis of chromosome 12q14-15 in multiple sclerosis: delineation of a 118-kb interval around interferon-gamma (IFNG) that is involved in male versus female differential susceptibility. Genes Immun. 2002 Dec;3(8):470-6.

135. Kantarci $\mathrm{OH}$, Hebrink DD, Schaefer-Klein J, et al. Interferon gamma allelic variants: sex-biased multiple sclerosis susceptibility and gene expression. Arch Neurol. 2008 Mar;65(3):349-57.

136. Spanier JA, Nashold FE, Olson JK, et al. The Ifng Gene Is Essential for Vdr Gene Expression and Vitamin D3-Mediated Reduction of the Pathogenic T Cell Burden in the Central Nervous System in Experimental Autoimmune Encephalomyelitis, a Multiple Sclerosis Model. J Immunol. 2012 Aug 15.

137. Lucas RM, Ponsonby AL, Dear K, et al. Sun exposure and vitamin D are independent risk factors for CNS demyelination. Neurology. [Comparative Study Multicenter Study Randomized Controlled Trial Research Support, Non-U.S. Gov't]. 2011 Feb 8;76(6):540-8.

138. Davis A, Deane GH, Diffey BL. Possible dosimeter for ultraviolet radiation. Nature. 1976 May 13;261(5556):169-70.

139. Flensner G, Ek AC, Soderhamn O, et al. Sensitivity to heat in MS patients: a factor strongly influencing symptomology--an explorative survey. BMC Neurol. 2011;11:27.

140. Romberg A, Ikonen A, Ruutiainen J, et al. The effects of heat stress on physical functioning in persons with multiple sclerosis. J Neurol Sci. 2012 Aug 15;319(1-2):42-6.

141. Norval M, Halliday GM. The consequences of UV-induced immunosuppression for human health. Photochem Photobiol. [Research Support, Non-U.S. Gov't Review]. 2011 Sep-Oct;87(5):965-77.

142. KWF Kanker Bestrijding. De relatie tussen kanker, zonnestraling en vitamine D, 2010.

143. Van der Mei IAF, Simpson Jr SL, S.A.M. K, et al. Role of vitamin D in Multiple Sclerosis: implications for disease management. Neurodegenerative Disease Management 2011;1(6):523-36. 
Chapter 10

Summary 


\section{CHAPTER 10}

Multiple sclerosis (MS) is an inflammatory disease of the central nervous system. The inflammatory process attacks the myelin sheaths around the axons of the brain and spinal cord. This results in a dysfunction of the neurons, causing a variety of neurological complaints depending on the location of the damaged neurons. Muscle weakness and sensory loss are well recognizable symptoms of MS. However, visual dysfunction, depressive symptoms, fatigue and cognitive complaints are also very common.

The consensus is that the inflammation in MS is mainly T cell mediated. In particular, CD4 T cells are thought to be the key mediators of the disease. CD4 ${ }^{+} \mathrm{T}$ cells are central players of the adaptive immune system and recognize processed peptide antigens, for instance derived from bacteria, which are presented via MHC class II by antigen presenting cells. After this recognition, CD4 T cells can differentiate into subtypes. Each subtype produces prototypic inflammatory mediators, called cytokines, which are important in mediating the clearance of the pathogen. In MS it is thought that $\mathrm{CD}^{+} \mathrm{T}$ cells recognize self-antigens, instead of pathogen-associated antigens. This results in an inflammatory response directed to the own body and therefore MS is considered an autoimmune disease. Normally, an excessive inflammatory response of CD4 T cells is prevented by regulatory $\mathrm{T}$ cells (Treg). However, in MS these Treg were shown to be less functional. At present, it is not known which antigen causes the autoimmune response, but myelin-associated antigens are putative candidates. Next to CD4 T cells, B cells gained attention in the disease pathogenesis of MS. B cells can play several roles in the pathogenesis. First, B cells are able to produce antibodies. In case these antibodies are reactive with auto-antigens, for instance in the myelin sheath, they can further enhance damage and inflammation. However, B cells also elaborate other functions, like antigen presentation and cytokine production. More recently, a special subset of $B$ cells has been discovered, i.e., regulatory B cells (Breg), which is thought to regulate and dampen immune responses. As is the case for Treg, also the effector function of Breg may be disturbed in MS.

Although much has been explored about the mechanisms involved in the disease process, the cause remains unknown. Theories on the aetiology include genetics and environmental factors. One of the environmental factors is vitamin D. Multiple studies show an association between a poor vitamin $\mathrm{D}$ status and increased disease incidence and disease activity or level of disability. In particular the immune modulatory function of vitamin $D$ is thought to be key in this association. Previous work showed a correlation between the function of Treg and vitamin D status in MS patients; a poor vitamin D status correlated with a worse function of Treg. These observations have led to trials in which MS patients are treated with vitamin D supplements, next to their regular treatment. Therefore, it is important to consolidate outcomes of interest to fully explore the effect of vitamin D supplements in MS. In this thesis we want to investigate 1 ) if characteristics of the B cell compartment are also associated with vitamin D status in MS, and 2) if clinical disease parameters, other than relapse rate or level of disability, are associated with vitamin D status in MS. 
In chapter 2, we review the role of vitamin D on the adaptive immune system. Experimental data in vitro and animal studies show that vitamin D plays an important role as a promoter of homeostasis of the adaptive immune system. The function of antigen presenting cells is altered, resulting in less $T$ cell proliferation and a change in cytokine production in favour of anti-inflammatory cytokines. As already mentioned, in humans, the function of Treg was reported to correlate negatively with vitamin D status. At least in vitro, B cell functions, like antibody and cytokine production were shown to be affected by vitamin D. In vivo, however, data about the effect of vitamin $D$ on B cells is scarce. In addition, the role of vitamin D on natural killer (NK) T cells and NK cells is unclear. In mice, vitamin D seems to play a role in the development of NK T cells, and in humans the cytotoxic function of NK cells may be altered by vitamin D, depending on the assay used. We conclude that data supports the view that vitamin $D$ is positively involved in maintaining or restoring immune homeostasis. However, it should be noticed that in vivo effects may differ from in vitro effects due to the crosstalk between different vitamin $D$ sensitive cells.

In chapter 3, we investigated in a cross-sectional study the effects of 12 weeks high-dose vitamin D3 supplementation on peripheral B cell differentiation, immunoglobulin production and levels of BAFF in 15 patients with RRMS. Despite a significant increase in serum 25-hydroxyvitamin D (25(OH)D), we found no significant shift in $B$ cell differentiation, isotype and subclass distribution, or plasma BAFF levels. Although this study had some limitations such as inclusion number, we concluded that in patients with MS, supplementation of high doses vitamin D3 does not have substantial effects on the distribution of peripheral blood $B$ cell subsets that are considered to reflect $B$ cell differentiation.

Like $T$ cells, also B cells differentially produce effector cytokines. Memory B cells produce more pro-inflammatory cytokines, while naïve $B$ cells produce more antiinflammatory cytokines. In addition, Breg are typically characterized by the production of IL-10. In chapter 4 we first explored peripheral blood B cell subsets, including Breg, in RRMS patients during remission and during active disease versus healthy controls. Since it is hypothesized that the naïve and memory Breg subsets have distinct roles in autoimmune diseases, we discriminated between these two Breg subsets. We found that RRMS patients have a decreased percentage of both memory B cells and Breg compared to healthy controls. During a relapse, the reduction in Breg involved in particular naïve Breg.

In chapter $\mathbf{4}$ we also explored the association between B cell subsets and vitamin D status. We found no correlation between vitamin D status and B cell subsets, including Breg. This observation does not exclude an effect of vitamin D on B cell subsets, since it might be the function that is interfered with instead of relative numbers.

In chapter $\mathbf{5}$ we switch towards clinical outcomes and we present a literature study about vitamin D and clinical outcomes. We review the evidence on the role of vitamin $\mathrm{D}$ in $\mathrm{MS}$ and whether vitamin D supplementation is effective for the management of 


\section{CHAPTER 10}

MS. Observational data suggest that higher vitamin $D$ levels are associated with lower relapse risk and there is promising evidence on its effect on MRI measures, disability progression, mental health and fatigue. We conclude that there is currently insufficient randomized controlled trial evidence to recommend vitamin $D$ supplementation with the aim to improve those outcomes. However, there is sufficient evidence to assess and correct vitamin D and calcium levels to optimize bone health in people with MS that are at high absolute risk of fracture.

To explore the effect of vitamin D on clinical outcomes more broadly, we started by exploring the correlation between vitamin $D$ status and visual dysfunction in chapter 6. Next to visual acuity, colour vision deficits, visual evoked potentials (VEP), retinal nerve fibre layer (RNFL) thickness was assessed using optical coherence tomography (OCT). A decline in RNFL thickness can also be considered as neurodegeneration. We found no correlation between functional visual outcome measures and vitamin D status in $27 \mathrm{MS}$ patients with a short disease duration ( $\leq 3$ years), with or without optic neuritis (ON). To our surprise, RNFL thickness correlated negatively with vitamin $D$ status in this cohort, in particular in patients without a history of ON. This observation might indicate that a high vitamin D status in MS patients without ON is not sufficiently protective for axonal damage. We concluded that high dose vitamin $D$ supplementation trials in MS should also include outcome measures of neurodegeneration such as RNFL thickness. In addition, future trials should include functional visual outcome measures to exclude a possible lack of effect on ocular functioning.

In chapters 7-8 we assessed the association between vitamin D status and depressive symptoms, anxiety, fatigue, and cognition in MS patients. We hypothesized that high vitamin $D$ status is associated with less symptoms of depression, anxiety, and fatigue and better cognitive performance. In a retrospective study (chapter 7), we found a negative correlation between vitamin $D$ status and depression scores. However, in a prospective study (chapter 8), we observed this negative association only for the highest category of vitamin $D(>80 \mathrm{nmol} / \mathrm{L})$. In chapter $\mathbf{8}$ we further expanded our findings by exploring the association between depression, anxiety, fatigue, cognition and sun exposure. We observed a negative association between reported sun exposure and scores of fatigue and depression in MS patients. Importantly, this association was largely independent of vitamin $D$ status (chapter 8), suggesting an effect of sun exposure largely outside the vitamin $D$ pathway. We concluded that vitamin $D$ supplementation trials will have to confirm whether high levels of vitamin $D$ have the capacity to reduce depressive symptoms in MS. Additionally, vitamin D supplementation trials will have to include measures of UVR exposure to explore whether UVR exposure has independent beneficial effects.

Altogether, in this thesis we further explored the role of vitamin $D$ on immunological and clinical outcome measures. Our in vivo studies could not confirm the immune modulatory effects of vitamin $D$ on $B$ cells which were previously shown in vitro. However, as described in chapter $\mathbf{9}$, increasing evidence suggests a role for B cells in the 
pathophysiology of MS with consequently more research on B cells in MS, leading to new markers, $B$ cell subsets, and B cell functions that might be of interest to explore a possible association with vitamin D status in MS. Additionally, we observed interesting associations between vitamin D status and clinical outcomes in MS patients. Importantly, we found that in some of these associations, sun exposure was associated independently from vitamin D with the clinical outcomes. Over the last year there have been some vitamin D supplementation trials in MS patients published. Only one of these trials studied, next to the standard clinical outcomes such as relapse rate or gadolinium enhancing lesions, clinical outcomes such as fatigue. In this single trial there was no association between vitamin D supplementation and less fatigue in MS patients. However, these findings need to be confirmed. Therefore, future randomized clinical trials will have to investigate the effect of vitamin $D$ to a large scale of MS symptoms, to fully explore the clinical effects of vitamin $D$ as a disease modulator in MS. Last but not least, it should be excluded that previously observed clinical associations with vitamin $\mathrm{D}$ are not an epiphenomenon of sun exposure. 

Chapter 11

Nederlandse samenvatting

Summary in Dutch 
CHAPTER 11 
Multiple sclerose (MS) is een ontstekingsziekte van het centrale zenuwstelsel. De ontsteking tast de myeline schedes rond de axonen in de hersenen en het ruggenmerg aan. Hierdoor kunnen de neuronen niet meer goed functioneren, waardoor diverse neurologische klachten ontstaan afhankelijk van de locatie van de beschadigde neuronen. Spierzwakte en sensibiliteitsverlies zijn veel voorkomende symptomen. Visus klachten, depressieve symptomen, vermoeidheid en cognitieve problemen komen echter ook veel voor.

Over het algemeen wordt aangenomen dat MS een T cel gemedieerde ziekte is. Vooral $\mathrm{CD}^{+} \mathrm{T}$ cellen lijken een belangrijke rol te spelen. $\mathrm{CD}^{+} \mathrm{T}$ cellen zijn belangrijke cellen van het verworven immuun systeem. Zij herkennen eiwit antigenen, zoals bijvoorbeeld van een bacterie, welke gepresenteerd worden via MHC klasse II door antigeen presenterende cellen. Wanneer $\mathrm{CD}^{+}{ }^{+} \mathrm{T}$ cellen dit antigeen herkennen, kunnen zij differentiëren in verschillende subtypes. leder subtype produceert een soort ontstekingsmediator, cytokines genaamd. Cytokines zijn belangrijk in het verdere proces waarbij het pathogeen wordt opgeruimd. Er wordt gedacht dat de $\mathrm{CD} 4^{+} \mathrm{T}$ cellen in MS patiënten lichaamseigen antigenen herkennen, in plaats van pathogeen geassocieerde antigenen. Dit resulteert in een ontstekingsreactie tegen het eigen lichaam. Daarom wordt MS als een auto-immuun ziekte beschouwd. Normaal wordt een te sterke reactie van $\mathrm{CD4}^{+} \mathrm{T}$ cellen voorkomen door regulatoire T cellen (Treg). In MS lijken deze Treg echter minder goed te werken. Tot op heden is het niet bekend welk antigeen de autoimmuun reactie veroorzaakt maar mogelijk spelen myeline geassocieerde antigenen een rol. Naast de rol van $\mathrm{CD}^{+}{ }^{\top} \mathrm{T}$ cellen lijkt het erop dat ook $\mathrm{B}$ cellen een belangrijke rol spelen de pathogenese van MS. B cellen zouden verschillende rollen kunnen hebben. B cellen zijn in staat om antilichamen te produceren. Wanneer deze antilichamen reageren op eigen antigenen, zoals bijvoorbeeld de myeline schedes, kunnen zij de ontsteking en schade verergeren. B cellen hebben ook andere functies, zoals bijvoorbeeld antigeen presentatie en cytokine productie. Vrij recent is er een speciale $B$ cel ontdekt, de regulatoire $B$ cel (Breg) waarvan gedacht wordt dat deze ook de immuun response kan afremmen. Zoals bij de Treg beschreven, is wellicht de functie van Breg ook aangedaan in MS.

Alhoewel er al veel onderzoek is gedaan naar onderliggende mechanismes van de ziekte, blijft de oorzaak onbekend. Er wordt gedacht dat zowel genetische als omgevingsfactoren een rol spelen. Een van de omgevingsfactoren is vitamine D. Meerdere studies laten een associatie zien tussen een lage vitamine $D$ status en een verhoogde incidentie van MS en een verhoogde activiteit van de ziekte. De immuun modulerende rol van vitamine $D$ zou een belangrijke rol kunnen spelen in deze associaties. Eerder werk toonde al een correlatie tussen de functie van Treg en vitamine D status in MS patiënten. Een lage vitamine $D$ status correleerde met een slechtere functie van Treg. Deze observaties hebben geleid tot trials waarin MS patiënten worden behandeld met vitamine $\mathrm{D}$ supplementen naast de reguliere behandelingen. Het is daarom van belang 


\section{CHAPTER 11}

om interessante uitkomstmaten te herkennen, zodat het effect van vitamine $D$ supplementen nog breder bekeken kan worden. In dit proefschrift wilden wij onderzoeken 1) of karakteristieken van het B cel compartiment ook geassocieerd zijn met vitamine D status in MS, en 2) of klinische ziekte parameters, anders dan ziekte activiteit of mate van handicap, geassocieerd zijn met vitamine D status in MS.

In hoofdstuk 2 beschrijven we een literatuurstudie over vitamine $D$ en het verworven immuunsysteem. Experimentele studies in vitro en in proefdieren laten zien dat vitamine $D$ een essentiële rol speelt als promotor van de homeostase van het verworven immuun systeem. De functie van antigeen presenterende cellen verandert onder invloed van vitamine $D$, wat leidt tot minder $T$ cel proliferatie en meer productie van anti-inflammatoire cytokines. Zoals vermeld is eerder beschreven dat de functie van Treg negatief correleert met vitamine D status. B cel functies, bijvoorbeeld antilichaam productie en cytokine productie, zijn in vitro ook beïnvloed door vitamine $\mathrm{D}$. Er is echter maar weinig in vivo data over B cellen en vitamine $D$ beschikbaar. Daarnaast is de rol van vitamine D op natural killer (NK) T cellen en NK cellen niet helemaal duidelijk. In muizen lijkt vitamine $D$ een rol te hebben in de ontwikkeling van NKT cellen en in mensen lijkt de functie van NK cellen aangedaan door vitamine D, afhankelijk van welke assay gebruikt is. We concluderen dat er data is welke ondersteunen dat vitamine $D$ betrokken is in het behouden en herstellen van de immuun homeostase. Het is echter belangrijk om te realiseren dat in vivo effecten kunnen verschillen van in vitro effecten doordat in vivo er nog een samenspel plaats kan vinden tussen vitamine D gevoelige cellen.

In hoofdstuk 3 hebben we in een cross-sectionele studie in 15 RRMS patiënten onderzocht wat het effect is van 12 weken hoge dosis vitamine D3 suppletie op de perifere $B$ cel differentiatie, immuunglobulinen productie en BAFF concentraties. Ondanks een significante stijging in 25-hydroxyvitamine $D(25(\mathrm{OH}) \mathrm{D})$, konden we geen significante veranderingen aantonen in $\mathrm{B}$ cel differentiatie, isotypes of concentraties van BAFF in het plasma. Hoewel deze studie enkele tekortkomingen had, zoals bijvoorbeeld een laag aantal patiënten, concludeerden we dat suppletie met hoge doses vitamine D3 geen groot effect heeft op de B cel differentiatie in het bloed.

Net zoals T cellen, kunnen B cellen ook verschillende cytokines produceren. Geheugen $B$ cellen produceren meer de pro-inflammatoire cytokines, terwijl naïeve $B$ cellen meer anti-inflammatoire cytokines produceren. Daarnaast wordt de Breg getypeerd door de productie van IL-10. In hoofdstuk $\mathbf{4}$ hebben we eerst B cel subsets in het bloed, inclusief Breg, bekeken in RRMS patiënten tijdens actieve ziekte en tijdens remmissie van de ziekte en vergeleken met dat van gezonde controles. Omdat er gedacht wordt dat de naïeve en geheugen Breg subset ieder een eigen rol hebben in auto-immuunziekten, hebben we een onderscheid gemaakt tussen deze twee Breg subsets. In RRMS patiënten vonden we een verlaagd percentage geheugen $B$ cellen en Breg vergeleken met gezonde controles. Het percentage naïeve Breg was vooral ver- 
laagd in RRMS patiënten gedurende een relapse. In hoofdstuk 4 hebben we ook de associatie tussen $B$ cel subsets en vitamine $D$ status bestudeerd. Er was geen correlatie tussen vitamine $D$ status en $B$ cel subsets, inclusief Breg. Dit wil niet zeggen dat er geen effect van vitamine D op B cellen, wij denken dat de functie, in plaats van relatieve aantallen, aangedaan kan zijn.

In hoofdstuk 5 switchen we van immunologische uitkomstmaten naar klinische uitkomstmaten. We beschrijven een literatuurstudie over vitamine $D$ en klinische uitkomsten. We onderzoeken het bewijsmateriaal dat vitamine $D$ een rol speelt in MS en of vitamine D suppletie effectief is als behandeling van MS. Observationele studies suggereren dat een hogere vitamine $D$ status geassocieerd is met een lager risico op relapses. Daarnaast is er veelbelovend bewijs dat vitamine $D$ effect heeft op MRI uitkomstmaten, ziekteprogressie, geestelijke gezondheid en vermoeidheid. We concluderen echter dat er op dit moment nog niet genoeg bewijsmateriaal is van gerandomiseerde gecontroleerde trials om vitamine $D$ suppletie aan te bevelen als een behandelingsoptie om bovenstaande uitkomstmaten te verbeteren. Maar er is wel genoeg bewijs om vitamine $\mathrm{D}$ en calcium status te corrigeren om de bot gezondheid te optimaliseren in MS patiënten die een hoog risico hebben op bot fracturen.

Om de effecten van vitamine $D$ op klinische uitkomstmaten breder te onderzoeken, zijn we in hoofdstuk 6 gestart met het onderzoeken van een correlatie tussen vitamine $D$ status en visus klachten. Naast visus, kleurenzien en visual evoked potentials (VEP), werd ook de dikte van de retinale zenuwvezel laag (RNFL) gemeten met optical coherence tomografie (OCT). Een afname van de dikte van de RNFL kan beschouwd worden als neurodegeneratie. We konden geen correlatie aantonen in $27 \mathrm{MS}$ patiënten met een korte ziekteduur ( $\leq 3$ jaar), met of zonder neuritis optica (NO), tussen visuele uitkomstmaten en vitamine $D$ status. Tegen onze verwachting in vonden we in dit cohort een negatieve correlatie tussen de dikte van RNFL en vitamine D status. Dit zou kunnen betekenen dat in MS patiënten zonder doorgemaakte NO een hoge vitamine $D$ status niet voldoende beschermd tegen axonale schade. We concludeerden dat de vitamine $D$ suppletie trials in MS ook uitkomstmaten zouden moeten includeren welke neurodegeneratie meten, zoals bijvoorbeeld de dikte van de RNFL. Het is ook aanbevolen om visuele uitkomstmaten mee te nemen om daadwerkelijk te bevestigen dat er geen effect is op oogheelkundige uitkomstmaten.

In hoofdstuk 7-8 hebben we in MS patiënten de associatie tussen vitamine D status en depressieve symptomen, angst, vermoeidheid, en cognitieve functie onderzocht. We hadden de hypothese dat vitamine $D$ status negatief correleerde met symptomen van depressie, angst, vermoeidheid en cognitief functioneren. In een retrospectieve studie (hoofdstuk 7), vonden we een negatieve correlatie tussen vitamine D status en depressie scores. In een prospectieve studie (hoofdstuk 8) vonden we deze negatieve associatie alleen in patiënten met de hoogste categorie vitamine $D$ (>80 nmol/L). In hoofdstuk 8 breidden we onze bevindingen uit door ook de associatie tussen depressie, angst, vermoeidheid, cognitie en zonblootstelling te onderzoeken. 


\section{CHAPTER 11}

We observeerden een negatieve associatie tussen gerapporteerde zonblootstelling en depressie scores in MS patiënten. Deze associatie was bovendien grotendeels onafhankelijk van vitamine $D$ status (hoofdstuk 8), wat suggereert dat zon blootstelling een effect heeft op depressie buiten vitamine $D$ om. We concludeerden dat vitamine $D$ suppletie trials zullen moeten bevestigen of een hoge vitamine $D$ status de capaciteit heeft om depressieve symptomen te verminderen in MS. Daarnaast zouden vitamine D suppletie trials uitkomstmaten van zonblootstelling moeten includeren om te onderzoeken of zonblootstelling nog onafhankelijke voordelige effecten heeft.

Al met al hebben we in dit proefschrift verder de rol van vitamine $D$ op immunologische en klinische uitkomstmaten verkend. Onze in vivo studies konden de immuun modulerende effecten van vitamine $D$ op $B$ cellen voorheen gevonden in de in vitro studies niet bevestigen. Echter, zoals beschreven in hoofdstuk 9, groeit het bewijs dat $B$ cellen betrokken zijn in de pathofysiologie van MS met consequent meer onderzoek naar B cellen in MS. Deze onderzoeken leiden tot nieuwe markers, B cel subsets en B cel functies, welke weer interessant zijn om te onderzoeken of zij geassocieerd zijn met vitamine $D$ in MS. Daarnaast hebben we interessante associaties gevonden tussen vitamine $D$ status en klinische uitkomstmaten in MS patiënten. We vonden dat in enkele van deze associaties zonblootstelling onafhankelijk van vitamine $D$ geassocieerd was met de klinische uitkomstmaten. De laatste jaren zijn er enkele vitamine D suppletie studies in MS patiënten gepubliceerd. Slecht één van deze studies heeft, naast de standaard klinische uitkomstmaten zoals aantal relapses of gadolinium aangekleurde laesies, klinische uitkomsten zoals vermoeidheid geïncludeerd. In deze trial werd er geen associatie gevonden tussen vitamine $D$ suppletie en minder moeheid in MS patienten. Deze bevindingen moeten echter nog wel bevestigd worden. Het is daarom van belang dat toekomstige gerandomiseerde klinische trials het effect van vitamine $D$ op een grotere schaal van MS symptomen onderzoeken, om de klinische effecten van vitamine $\mathrm{D}$ als een ziekte modulator volledig in beeld te brengen. Tot slot, het moet uitgesloten worden dat de associaties die voorheen gevonden zijn tussen vitamine $D$ status en klinische uitkomstmaten niet een epi fenomeen zijn van zonblootstelling. 


\section{Dankwoord}

Acknowledgements 


\section{DANKWOORD}

En dan nu mag ik eindelijk het dankwoord schrijven! Dit betekent dat het boekje echt klaar is. Ik wil iedereen van harte bedanken die heeft bijgedragen aan de voltooiing van dit proefschrift.

Allereerst wil ik alle patiënten bedanken die hebben meegedaan aan de studies. Zonder uw bereidheid en inzet was er geen vitamine D onderzoek mogelijk.

De leden de leescommissie en de corona bedank ik voor het lezen en beoordelen van mijn proefschrift.

Mijn promotoren Raymond Hupperts en Jan Willem Cohen Tervaert wil ik graag bedanken. Bedankt voor jullie vertrouwen en jullie klinische en wetenschappelijke expertise welke onmisbaar zijn geweest tijdens mijn promotietraject.

Ik wil heel graag mijn co-promotor Jan Damoiseaux van harte bedanken. Jan, je hebt me alles bijgebracht dat belangrijk is om goed onderzoek te doen! Je inzet voor het vitamine $D$ en MS onderzoek is onmisbaar en ik hoop dat er nog meer promovendi van jouw goede begeleiding mogen profiteren. En dat fietstochtje door de Limburgse heuvels moet er dan ook maar eens van komen!

Yvonne Bol, mijn tweede co-promotor, jouw steun, input en bereidheid om altijd de puntjes op de i te willen zetten zijn zeer waardevol voor me geweest. Ik wil je vooral bedanken voor je kritische en frisse blik op mijn manuscripten.

Beste Raymond, Jan Willem, Jan en Yvonne, ik heb veel van jullie geleerd. Ik ben er trots op dat ik, dankzij jullie inzet en onze goede samenwerking, MS in dit proefschrift multidisciplinair heb kunnen benaderen.

Mariëlle Thewissen, ik had weinig ervaring met lab werk en wilde bovendien de rol van $B$ cellen in MS gaan onderzoeken....! Bedankt dat je het geduld had mij hierin te ondersteunen en dat je naast je onderwijsverplichtingen en het metabool syndroom onderzoek altijd tijd en energie hebt willen steken in het MS onderzoek.

En natuurlijk mijn collega's in het MS onderzoek. Joost (middle name 'enthousiasme'), met jouw enthousiasme weet jij iedere bevinding tot een feest te maken! Jouw deur stond altijd open voor hulp en advies. Ik heb veel over onderzoek van jou geleerd. Evelyn, bedankt voor jouw geduld, de vele metingen die jij voor me hebt overgenomen en de vele kopjes koffie bij DE waarbij we even goed konden sparren. En natuurlijk bedankt dat jij mijn paranimf wilt zijn!

Anne-Hilde en Linda, bedankt voor jullie frisse inzet in het MS onderzoek, ik kijk uit naar de samenwerkingen die nog gaan komen! En ik wens jullie heel veel succes met het vervolg van MS studies.

Verder dank aan de 'andere' PhD studenten van de experimentele immunologie: Benjamin, Annelien, Steven en Marc voor de feedback tijdens besprekingen en de 
gezelligheid tijdens congressen. Dank natuurlijk ook aan de analisten van de afdeling klinische en experimentele immunologie voor de technische ondersteuning.

Dr. Sanders, bedankt voor uw begeleiding in de OCT studie.

De MS verpleegkundigen in Sittard: Bertine, Tiny, Ingrid, Judith, Sandra, Maartje, Lianne en Mariëlle. MS patiënten zijn altijd vol lof over jullie, en terecht! Jullie betrokkenheid en alertheid is een groot goed voor het academisch MS centrum Limburg.

De MS verpleegkundigen in Breda: Anja, Karin, Véronique, Monique en Martine. Het was altijd een eind rijden, maar ik voelde me altijd erg welkom en jullie hadden altijd alles perfect geregeld.

Oogartsen Dr. Porro en Dr. van den Maegdenbergh, bedankt voor jullie metingen in de OCT studie. Dagmar Poelma en John van der Veerdonk, bedankt voor alle OCT metingen.

Ingrid van der Mei, bedankt voor het vertrouwen om een Tasmanië-Maastricht samenwerking aan te gaan. Ik had wat moeite met Stata en het interpreteren van de uitkomsten, maar jij leidde me er op afstand iedere keer moeiteloos doorheen. Bedankt voor de vele uren die jij hebt willen stoppen in het vitamine $D$ en depressie stuk! Furthermore I would like to thank Steve Simpson. You were an expert in turning the results upside down, which in the end improved the vitamin $D$ and depression manuscript significantly.

Jaap Jansen en Frank van Bussel, bedankt voor jullie samenwerking in de, nog lopende, fMRI MS studie. Paul Menheere, Mario Vogt en Joop ten Kate, bedankt voor de vele vitamine $D$ metingen die in jullie laboratoria hebben mogen plaatsvinden.

Diana Neele en Marianka van der Tol van TEVA. Diana bedankt voor je vele stimulerende mailtjes en telefoontjes. Dankzij jouw enthousiasme is de OCT studie een succes geworden.

Mijn lieve kamergenootjes Rianne, Amy en Birgit! Wat kon het een heerlijke meidenboel op onze kamer zijn. Heerlijk om zo snel van onderwerp te veranderen; van proefpersonen en statistiek, naar huisdieren, schoenen en bruiloften en weer terug naar de orde van de dag. Het maakte de afgelopen jaren heel aangenaam! Amy, bedankt voor de vele rondjes rennen, je was vaak net even de stok achter de deur die ik nodig had.

Ook de maatschap Neurologie te Sittard mag hier niet ontbreken. Mijn enthousiasme voor de neurologie is in de tijd bij jullie alleen maar groter geworden. Bedankt ook dat jullie mij na 4 jaar onderzoek weer opnieuw begeleiden in de kliniek. 


\section{DANKWOORD}

Uiteraard wil ik mijn vrienden bedanken die het hele promotietraject op een afstandje hebben gevolgd en voor de nodige ontspanning hebben gezorgd: Saskia, Diana, Inge en Mirte. Wat fijn dat we elkaar regelmatig nog blijven zien! Ik hoop dat we onze traditie van weekendjes weg nog heel lang volhouden! Geke, Jessica, Suzan, fijn dat jullie er altijd zijn op de belangrijke momenten.

Femke, Jeroen, Sjoerd en Nora, jullie heerlijke nuchtere kijk konden Reint en ik vaak goed gebruiken in deze periode. Bedankt voor de talloze gezellige en bourgondische etentjes. Fem, ik ben blij en trots dat je achter me staat als paranimf.

En natuurlijk familie. Lieve pa en ma, ik ben trots op jullie als mijn ouders. Jullie staan altijd klaar voor me en jullie hebben mij alle mogelijkheden gegeven. Daarvoor ben ik jullie heel erg dankbaar.

Esther en Ivo, en natuurlijk mijn schoonfamilie, ook jullie waren altijd geïnteresseerd hoe het nu met het onderzoek stond, maar zorgden er vooral voor dat we juist even helemaal niet aan het onderzoek dachten.

Lieve Reint, als geen ander weet je wat een promotietraject inhoudt en als geen ander weet je wat een promotietraject voor mij betekent. Je bent mijn maatje en ik ben er trots op dat ik je sinds kort ook mijn man mag noemen. Het leven is goed met jou, en met Moos natuurlijk! 


\section{Publications}




\section{PUBLICATIONS}

Ubachs JF, Engblom H, Hedström E, Selvester RH, Knippenberg SA, Wagner GS, Gorgels AP, Arheden $\mathrm{H}$. 'Location of myocardium at risk in patients with first-time ST-elevation infarction: comparison among single photon emission computed tomography, magnetic resonance imaging, and electrocardiography.' J Electrocardiol. 2009 MarApr;42(2):198-203.

Knippenberg SA, Wagner GS, Ubachs JF, Gorgels A, Hedström E, Arheden H, Engblom $\mathrm{H}$. 'Consideration of the impact of reperfusion therapy on the quantitative relationship between the Selvester QRS score and infarct size by cardiac MRI.'Ann Noninvasive Electrocardiol. $2010 \mathrm{Jul} ; 15(3): 238-44$.

Hilde M. H. Braakman, Stephanie A. M. Knippenberg, Bert-Jan de Bondt, Jan Lodder. 'An Unusual Cause of Transient Neurologic Deficits: Compression of the Carotid Artery by a Thyroid Cystic Nodule.' Journal of Stroke and Cerebrovascular Diseases, Vol. 19, No. 1 (January-February), 2010: pp 73-74.

S. Knippenberg, Y. Bol, J. Damoiseaux, R. Hupperts, J. Smolders. 'Poor vitamin D status is correlated with depression, but not fatigue in multiple sclerosis.' Acta Neurol Scand. 2011 Sep;124(3):171-5

Smolders J, Thewissen M, Theunissen R, Peelen E, Knippenberg S, Menheere P, Cohen Tervaert JW, Hupperts R, Damoiseaux J. Vitamin D-related gene expression profiles in immune cells of patients with relapsing remitting multiple sclerosis. J Neuroimmunol. 2011 Jun;235(1-2):91-7

S. Knippenberg, R. Hupperts, J. Damoiseaux. Multiple sclerosis. Bookchapter EASI Booklet for Family Doctors. 2012

Stephanie Knippenberg, Evelyn Peelen, Anne-Hilde Muris, Mariëlle Thewissen, Joost Smolders, Raymond Hupperts, Jan Willem Cohen Tervaert, Jan Damoiseaux. 'Effects of vitamin $D$ on the peripheral adaptive immune system: a review'. Autoimmunity Reviews,. 2011 Oct;10(12):733-43.

S. Knippenberg, J. Smolders, M. Thewissen, E. Peelen, JW Cohen Tervaert, R. Hupperts, J. Damoiseaux. Effect of vitamin D3 supplementation on peripheral B cell differentiation and isotype switching in patients with multiple sclerosis. Mult Scler. 2011 Dec;17(12):1418-23. 
S. Knippenberg, J. Smolders, M. Thewissen, E. Peelen, JW Cohen Tervaert, R. Hupperts, J. Damoiseaux. Reduction in IL-10 producing B cells (Breg) in multiple sclerosis is accompanied by a reduced naïve/memory Breg ratio during a relapse but not in remission. J Neuroimmunol. 2011 Oct 28;239(1-2):80-6.

E. Peelen, J. Damaoiseaux, J. Smolders, S. Knippenberg, P. Menheere, JW Cohen Tervaert, R. Hupperts, M. Thewissen. Th17 expansion in MS patients is counterbalanced by an expanded $\mathrm{CD}_{39}\left(^{+}\right.$) regulatory $\mathrm{T}$ cell population during remission but not during relapse. J Neuroimmunol. 2011 Dec 15;240-241:97-103.

S. Knippenberg, J. Damoiseaux. 25-hydroxyvitamin D level prediction models--is further optimization feasible? Neuroepidemiology. 2012;39(2):94-5.

S. Knippenberg, J. Damoiseaux, Y. Bol, R. Hupperts, BV. Taylor, A-L. Ponsonby, T. Dwyer, L. Blizzard, S. Simpson Jr, I. van der Mei. Higher levels of reported sun exposure, and not vitamin D status, are associated with less depressive symptoms and fatigue in MS. Submitted for publication.

S. Knippenberg, J. Damoiseaux, G. Porro, M. van de Maegdenbergh, E. Sanders, R. Hupperts. Vitamin D status in MS correlates negatively with retinal nerve fibre layer thickness. Submitted for publication. 

Curriculum vitae 
CURRICULUM VITAE

198 
Stephanie Knippenberg werd op 29 januari 1983 geboren in Bergen op Zoom. Zij behaalde haar VWO diploma in 2001 aan het Moller Lyceum te Bergen op Zoom. Hierna studeerde zij geneeskunde aan de Universiteit Maastricht, waar zij in 2007 afstudeerde. In het laatste jaar van haar studie deed zij haar participatie in de wetenschap (WESP) aan Duke University (Durham, North Carolina, Verenigde Staten). Daarna koos zij voor de participatie in de gezondheidszorg (GEZP) Neurologie in het Maastricht Universitair Medisch Centrum (MUMC). Na haar afstuderen begon zij te werken als arts-assistent op de afdeling Neurologie in het Maasland ziekenhuis in Sittard. In oktober 2008 startte zij als PhD-student met het onderzoek naar vitamine D in MS patienten, onder supervisie van professor Hupperts en professor Cohen Tervaert, waarvan de resultaten in dit proefschrift staan beschreven.

Vanaf oktober 2012 is zij werkzaam als arts-assistent Neurologie in het Orbis Medisch Centrum te Sittard. Stephanie is getrouwd met Reint Jellema. Zij wonen samen in Maastricht.

Stephanie Knippenberg was born on January $29^{\text {th }}, 1983$ in Bergen op Zoom (The Netherlands). In 2001 she graduated her secondary school education (VWO) at the Moller Lyceum in Bergen op Zoom. Subsequently, she studied medicine at Maastricht University (Maastricht, The Netherlands), where she graduated in 2007. During her last study year, she did her participation in science (WESP) at Duke University (Durham, North Carolina, USA). After that she chose the participation in healthcare (GEZP) Neurology at Maastricht University Medical Centre (MUMC). After her study, she started working as a resident on the department of Neurology at Maasland Hospital Sittard. In Octobre 2008 she started as a PhD-student in vitamin D and MS research under supervision of professor Hupperts and professor Cohen Tervaert. The results of this research are presented in this thesis.

Since Octobre 2012 she is working as a resident on the deparment of Neurology of Orbis Medical Centre Sittard. Stephanie is married to Reint Jellema. They live together in Maastricht. 